\title{
Timing Grace
}

Reflections on the Temporality of Preaching

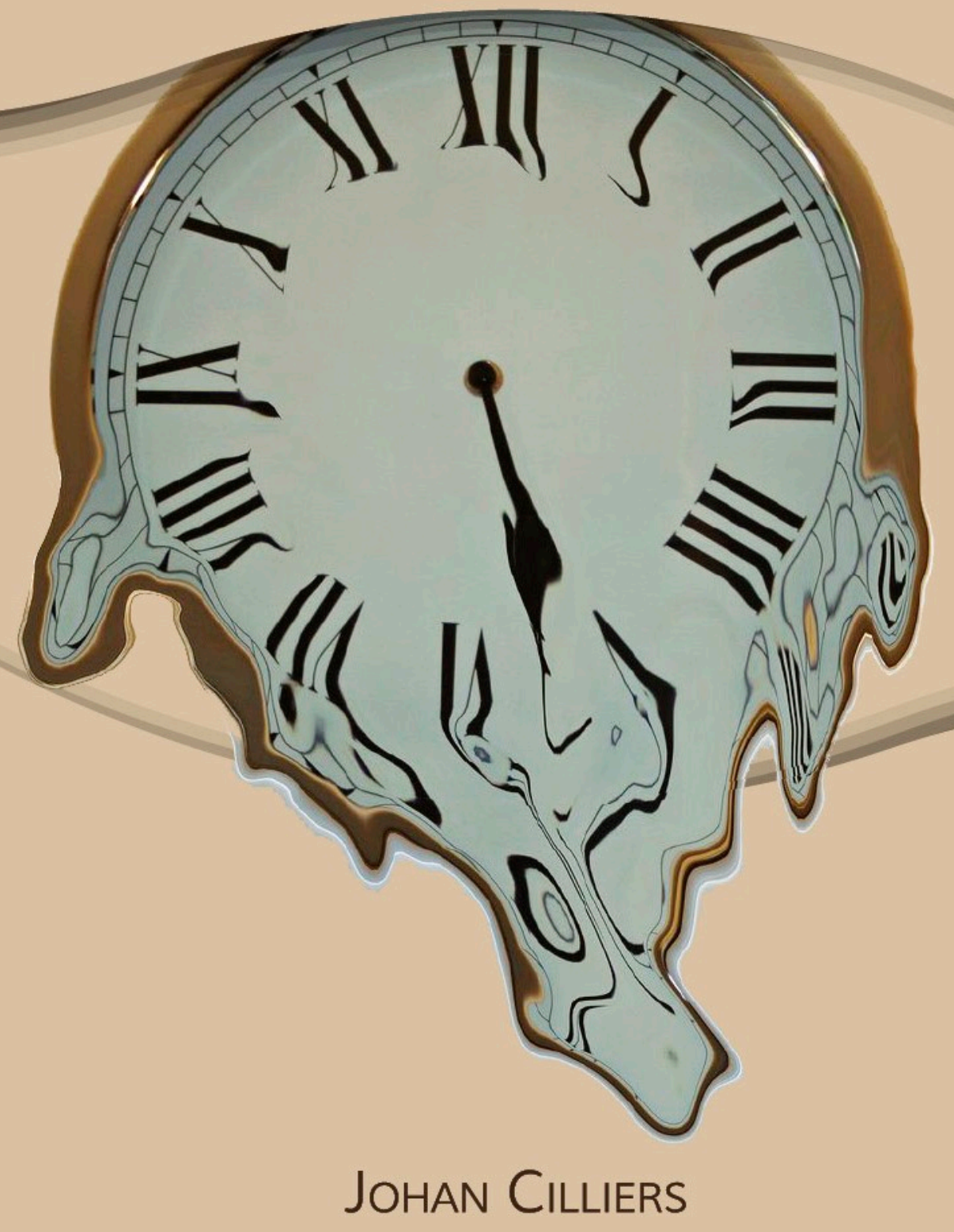


Timing Grace: Reflections on the Temporality Preaching

Published by AFRICAN SUN MeDIA under the SUN PReSS imprint

All rights reserved

Copyright (C) 2019 AFRICAN SUN MeDIA and the author

This publication was subjected to an independent double-blind peer evaluation by the publisher.

The author and the publisher have made every effort to obtain permission for and acknowledge the use of copyrighted material. Refer all enquiries to the publisher.

No part of this book may be reproduced or transmitted in any form or by any electronic, photographic or mechanical means, including photocopying and recording on record, tape or laser disk, on microfilm, via the Internet, by e-mail, or by any other information storage and retrieval system, without prior written permission by the publisher.

Views reflected in this publication are not necessarily those of the publisher.

First edition 2019

ISBN 978-1-928480-22-8

ISBN 978-1-928480-23-5 (e-book)

https://doi.org/10.18820/9781928480235

Set in Warnock 10.5/14

Cover design, typesetting and production by AFRICAN SUN MeDIA

Cover image: Adaptation of The Persistence of Memory (1931) by Salvador Dalí

SUN PReSS is a licensed imprint of AFRICAN SUN MeDIA. Scholarly, professional and reference works are published under this imprint in print and electronic format.

This publication can be ordered directly from:

www.sun-e-shop.co.za

www.store.it.si (e-books)

www.africansunmedia.co.za 


\title{
Timing Grace
}

\author{
Reflections on the \\ Temporality of Preaching
}

Johan Cilliers 


\section{REVIEWS}

"Timing Grace is an integration of the latest academic homiletical literature with artworks and sermons. The act of reading this book is in itself an almost poetic-aesthetic experience ..."

"Timing Grace is a timely book for the field of Homiletics as well as for preachers in South Africa and beyond. This book is once again a clear indication that Johan Cilliers is currently the foremost South African homiletician and an important international voice in the field."

Cas Wepener, University of Pretoria

"Reading this work on the nature of preaching as 'timing grace', the author managed to take me to another place - interrupting the deterministic onslaught of time of which all of us are prisoners ... The book, which is almost a type of sermon in itself, manages to 'create' time as a space for simultaneously remembering and forgetting - a necessary 'art' for prophetic preaching."

"Profound and beautifully written!"

Dr Tanya van Wyk, University of Pretoria

In A Space for Grace, (the companion volume to Timing Grace), Cilliers “... reaffirmed his position as one of the most creative and venturesome scholars at work in the homiletical world".

Prof Thomas G. Long, Emory University 


\section{TABLE OF CONTENTS}

PREFACE

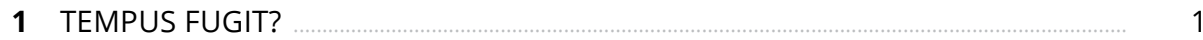

Sermon: My times are in your hands .............................................

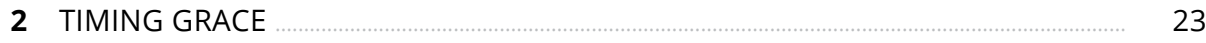

Sermon: Truth or fiction? $\ldots$

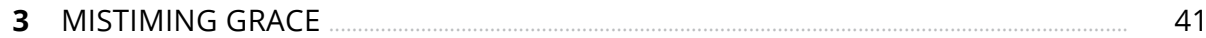

"The gospel as law for the hour..."?

"In times like these..."?

"Is history repeating itself..."?

"Crossing the Jordan..."?

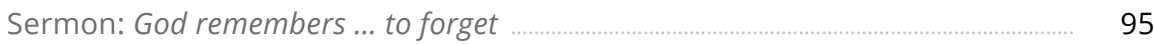

4 INTERRUPTING TIME $\ldots$

Allan Boesak: a moral discourse of indictment

Desmond Tutu: a utopian mode of moral discourse

Beyers Naude: an ethical mode of moral discourse

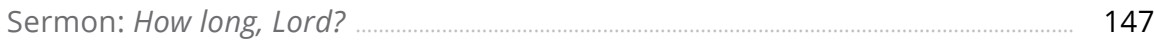

5 WASTING TIME?

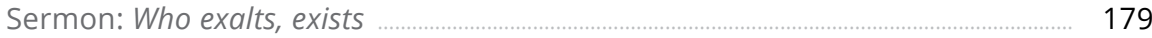

6 TIMING THE TEXT $\ldots$

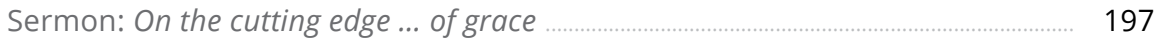

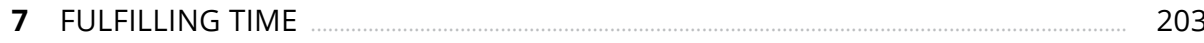

Sermon: A time to be born, a time to die ..................................................... 219

8 A TIMELY CONCLUSION _ _

BIBLIOGRAPHY 


\section{LIST OF FIGURES}

1.1 Arthur Ganson: Machine with Concrete (1992)

1.2 Salvador Dalí: The Persistence of Memory (1931)

2.1 Felix Gonzalez-Torres: 'Untitled' Perfect Lovers (1987-1990)

3.1 Worku Goshu: Resurrection (1981)

3.2 Frank Meisler: Trains to Life; Trains to Death (2008)

3.3 Frank Meisler: 5 Kindertransport (2008)

3.4 Karol Broniatowski: Gleis 17 Grunewald Railway Station Memorial (1991)

4.1 Hans Holbein: The Ambassadors (1533)

4.2 Hans Holbein: The Ambassadors: The Skull seen from side-perspective (1533)

4.3 e'Lollipop: Forever Young, Forever Free (1975)

4.4 Tacheles: How Long is Now (2010)

5.1 Joseph Beuys: Crucifixion (1962-1963)

5.2 Children playing on refuse dump-heap (1984)

5.3 Johan Cilliers: Karoo: Beautiful Nothingness

5.4 Langerman: Karoo by night: probing beyond the borders of the finite

5.5 Johan Cilliers: Karoo: Genesis of Now

5.6 Shale Stuff: Process of Fracking (2014)

5.7 Zapiro: No Fracking in the Karoo (2011)

5.8 Katie Barnard du Toit: Fear and Loss (2014)

6.1 Steve Reich: Phase to Face (2018)

7.1 Johan Cilliers: Depiction of John Mbiti's understanding of African time

7.2 Lonyana rock in KwaZulu-Natal

8.1 Timothy Schmalz: Homeless Jesus (2012) 


\section{PREFACE}

In spe. When I started out with my studies in Heidelberg, Germany, under the Swiss-German practical theologian Rudolf Bohren, he called me: Doctor in spe - Doctor in hope. This has become a type of credo for me, guiding me from the past, through the time(s) and space(s) of the present, towards the future ...

Writing about time and space, I have become acutely aware of the gift of time and space, but also the transience of time and space. We are granted - through grace - a space for time, and a time for space. For us, neither space nor time will last everywhere, or forever. At least, not according to our (current) understanding of time and space.

As I write these words, I am in a particular time and space. To be precise: looking out the window on a rather rainy autumn day, on 2 October 2018, in Amstelveen, the Netherlands, at 10:23 in the morning. ${ }^{1}$ In a few seconds, this particular time and space, this 'here and now', will be no more. The seconds that should have ticked by, would have done so; the rain that should have fallen, would have done so - never to be repeated in the same way. In 50, or 100 years from this moment called 'now', if anyone should read these words (if people will still read, and there will still be things called books!) - humanity's understanding of space and time will have changed, probably fundamentally so. Perhaps the evolution of technology will make what this book proposes about space and time, and about preaching within space and time, seem rather infantile. It will be 'outdated'; indeed 'anachronistic' - for such is the nature of the flow of time. After all, our days pass by like a thought; we fly to our end. ${ }^{2}$ Everything is fleeting, so fleeting. 
I am of the opinion however, that preaching, albeit in different forms, will withstand the test of time. I realise also that what I advocate in this book, could probably be evaluated as being a romanticised, even idealistic view on preaching. I suspect strongly that not all sermons, delivered every Sunday from pulpits, or in whatever space and time, will yield the fulfilling 'now' that I am profiling here. And yet, I cannot give up this hope ...

Some years ago, I wrote a book entitled A Space for Grace. Towards an Aesthetics of Preaching. It is now time, for me, to write a book entitled Timing Grace. Perspectives on the Temporality of Preaching. As was the case in A Space for Grace, this book also (and perhaps even more so) does not offer ready-made recipes for creating sermons, but hopefully, it again addresses some of the most fundamental (theological) underpinnings of the act and art that we call preaching.

A Space for Grace was written from an aesthetical point of view. Timing Grace follows this endeavour, knowing full well that aesthetics indeed offers no quick fixes, rather a plethora of possible perspectives. In the words of Søren Kierkegaard: "Aesthetics is the most treacherous of all sciences. Everyone who has loved it becomes, in a certain sense, unhappy; but whoever has never loved it, is and remains (like) cattle." ${ }^{3}$ A sentiment echoed by Ludwig Wittgenstein: "Everything is all right; and nothing is. In this situation the one who searches for definitions in Aesthetics finds himself."

In this book, again, I will be making use of some aesthetical depictions, in order to express the inexpressible. Obviously, these depictions are open; and indeed, call for, other interpretations than those suggested here. And, because this is a book about preaching, I not only included some extended analytical comments on sermons, but also sermons and meditations to be read and interpreted on their own. In this way, I hope so-called theory and practice will somehow dovetail, or at least create spaces and times for critical dialogue, in the form of synchronisation and/or interruption. In the sermons, I have not added footnoted sources as in the rest of the book.

No book comes to being without dialogue with, and support of 'others' - the latter here being a rich variety of people and institutions. I thank some of them, without

"Die Ästhetik ist die treuloseste aller Wissenschaften. Jeder, der sie recht geliebt hat, wird in einem gewissen Sinne unglücklich; wer sie aber niemals geliebt hat, der ist und bleibt ein Vieh," Kierkegaard (1961); Reinbek (1961:91).

4 "Es stimmt alles; und nichts ... in dieser Lage befindet sich ... der, der in der Aesthetik ... nach Definitionen sucht ..."Wittgenstein (1969:77,329). 
whom this book would not have been possible: Stellenbosch University, for granting me sabbatical-time for doing research; Prof Eugene Cloete, Vice-Rector for Research, Innovation and Post-Graduate Studies, Stellenbosch University, for the generous financial contribution made towards the realisation of this book, as well as the joint curatoria of the Dutch Reformed Church and the Uniting Reformed Church in Southern Africa of the Faculty of Theology at Stellenbosch University for their substantial and indispensable contribution; the Humboldt University (Berlin), for creating a space for me to continue my writing; the Protestant Theological University of Amsterdam (PThU) for inviting me as Research Fellow during the Autumn of 2018; numerous colleagues and friends from the Societas Homiletica, over many years; the publisher, AFRICAN SUN MeDIA, whose professionalism and courtesy towards, and trust in me, knew no bounds; my Department (Practical Theology and Missiology) in Stellenbosch, for simply still putting up with me; the Head of our Department, Xolile Simon, for being a friend and colleague that enriched my thinking on African Spirituality in a variety of ways; Daniël Louw, from South Africa, who has been an inspiring, if not provocative dialogue partner concerning aesthetics on countless occasions; Ian Nell, my adventurous friend, also from South Africa, who never fails to take me out of my (physical and theological) comfort zones; Wilhelm Gräb, from the Humboldt University, Berlin, for often offering challenging alternatives; Annekie Joubert, from the Kultur-, Sozial- und Bildungswissenschaftliche Fakultät; Institut für Asien- und Afrikawissenschaften; Afrikanische Sprachen (Humboldt University, Berlin), for introducing me to additional insightful literature concerning African Time; Alexander Deeg, who invited me to take part in three international homiletical conferences, held in Braunschweig, Germany, where some of my first thoughts reflected in this book, was born; Marcel Barnard (from the Protestantse Theologische Universiteit (PThU), Netherlands), who has been a constant source of wisdom, over many years; colleagues Mirella Klomp, Rein Brouwer and Ciska Stark, also from the PThU, who all made valuable comments on my research topic - further enriched by aesthetical inputs from Henk Vogel and Lydia Leersum-Bekebrede, from the same institution. Last but not least, my long-standing friend from the United States of America, Charles Campbell (Duke University), whose notion of interruption continuous to interrupt my homiletical status quo, for the good.

Again, I thank my wife, Elna, and my children, Jacques and Karen, for granting me time and space to write about time and space.

In spe ... 


\section{Chapter 1}

TeMPus Fugit?

Time has fascinated me for a long time. ${ }^{1}$ I remember, while travelling on a train in Belgium, picking up a piece of paper from the seat in order to sit down, my eye fell on the word: 'time.' I suppose the fragment of paper came from the world of astrophysics (there was not enough information to detect the exact source), and it referred to a fascinating theory, more or less as follows:

If you take a ball, and enlarge it constantly, it will obviously become bigger and bigger. If you increase the speed of enlargement, i.e. taking less time to do so, the ball will grow bigger even faster. If you could speed up this process until you get to time zero, there will only be present (now), and no past or future ... and an infinitely huge ball! Then time (the speed of enlargement), and space (the circumference of the ball) collapse into ... yes, what? Another dimension? A new, so-called fourth dimension? ${ }^{2}$

1 Obviously, I am not the only one. Interest in time as such has become quite popular, as illustrated by the art installation by video artist Christian Marclay, entitled The Clock. Basically, the art work is about a 24-hour video montage or collage of scenes from film and television that feature clocks or timepieces. The interesting aspect of this work is the fact that these clips from film and television are synchronised with real time, in effect functioning as a clock itself. Each clip in a scene therefore corresponds to actual time, stretching over 24 hours. The film's debut was in 2010 at White Cube's London gallery, and the impact of the film was felt immediately - it received critical praise, and won the Golden Lion Award at the 2011 Venice Biennale. The six editions of the film were purchased by major museums, and thousands literally flocked to view the film, sitting in in different time zones during the 24-hour screening, knowing that it was synchronised to real time. It indeed seems as if humanity wishes to view their future in terms of a prolonged, i.e. 'eternal' take on time. Another case in point would be the so-called Clock of the Long Now, being constructed in the USA - a clock driven by solar energy and buried deep within the Earth, in an underground facility in west Texas. This clock was designed by Danny Hillis and is intended to run for ten millennia with minimal maintenance and interruption. The Clock is powered by mechanical energy harvested from sunlight as well as the people that visit it. The primary materials used in the Clock are marine grade 316 stainless steel, titanium and dry running ceramic ball bearings - an indication that this timepiece is clearly intended for 'eternity'. See the discussion in Chapter 2 on the 'synchronization of times'.

2 The notion of a fourth space dimension is indeed not new, and has been debated in a variety of disciplines, stretching from mathematics to philosophy to science fiction to literature to physics, etc. The term was probably coined the first time by Charles Howard Hinton in 1880. It is generally accepted that the idea of a fourth space in mathematics follows the rules of three-dimensional Euclidean space, while the concept, as it is used in physics is not to be confused with Euclidean space - as has often happened in modern science fiction and philosophical writings. It was Hermann Minkowski who introduced the notion of a fourth space dimension within the field of physics in 1908 and postulated a unification of time and space to form the fourth space, the so-called 'Minkowski space-time continuum'. The latter formed the basis 
Of course, I am not an astrophysicist. I am, or profess to be, a Professor of Homiletics, trying to teach students, and myself, the art and act of preaching. I am of the opinion, however, that preaching has everything to do with time and space, these age-old, classic concepts; and that time and space has everything to do with preaching. In fact, I am convinced that preaching somehow creates (another; a new) time and space, i.e. an 'alternative dimension'.

On the other hand it is important to note from the outset that this new, alternative dimension should not be equated with certain forms of mysticism and/or mythological understandings of time. ${ }^{3}$ The intention of this envisaged enriched experience of time is not to forsake the dimensions of time and space in which we live. On the contrary, this 'new' time "... is no fairyland where people experience time in a way that is markedly unlike the way in which we do ourselves, where there is no past, present and future, where time stands still, or chases its own tail, or swings back and forth like a pendulum."

Some time ago, I wrote a book about the relationship between preaching and space, entitled: A Space for Grace. Towards an Aesthetics of preaching. ${ }^{5}$ I realised, already then, that one can hardly talk about space, without implying time, and vice versa. I contended:

Space cannot be understood without its relationship to time. ${ }^{6}$ Space and time in fact form the basic structures within which we exist; everything that exists, also movement, takes place within space and time - and space and

\footnotetext{
for the breath-taking breakthroughs that people like Einstein and Hawking propagated concerning our understandings of space and time within the setting of our cosmos. Einstein used the idea of space-time, i.e. a fourth space dimension to develop his theories of special and general relativity. Hawking affirmed this: "We must accept that time is not completely separate from and independent of space but is combined with it to form an object called space-time." Hawking (1989:24). He even postulated that time only 'exists' when we measure it. In this sense, one could perhaps speak of 'measured' and 'unmeasured' time. Obviously, I will not be dealing with these astrophysical understandings of fourth space in this book but will nonetheless be utilising this concept in view of a spatial-temporal understanding of preaching, albeit in different terms. For a good overview of the general development of the notion of fourth space, cf. Hawking and Mlodinow (2010:99-101).

3 In this book, I will be using certain dimensions of so-called mythical (or circular) time, but also of so-called linear time - avoiding the excesses on both sides. Cf. the discussion in Chapter 3 and 7.

Gell (1992:315).

Cilliers (2016a).

The importance of time, and its relationship to space, is discussed further on in this book; the notion of time-space (chronotope) indeed forms a leitmotiv throughout the whole book. Through a new understanding of our reality, the present (time) can in fact become a sacred space, can gain a pregnant fullness, a fullness of the moment - where time is concentrated, thickened. The present then becomes full of the past, but also proleptically celebrates the future. Yes, “... beginning and end are there, but central places, holy places, sacred places, and memory places are intensely present." Friedland and Hecht (2006:35).
} 
time themselves also move. ${ }^{7}$ Space and time are related to one another, but are also in c onstant tension with one another - one could indeed call it the fundamental tension of our existence. ${ }^{8}$

Preaching is an event that takes place in space and time. This might sound like an obvious statement, but it does articulate the deepest mystery of the act that we call 'preaching'. Reflecting on the aesthetics of preaching, I will constantly be revisiting this relationship and tension of space and time. When I will be speaking about space, the notion of time will always be lingering in the background; when I will be referring to time, space will always be implied. ${ }^{9}$

This book is about time, about the relationship between preaching and time, again, in conjunction with the notion of space. It is extremely difficult, if not impossible, to describe the phenomenon of time. Time seems to be out of our hands, and never under our control. ${ }^{10}$ This is partly because we cannot disentangle ourselves from such a basic vehicle of our existence - “... pursuing Time, we are like a knight on a quest, condemned to wander through innumerable forests, bewildered and baffled, because the magic beast he is looking for is the horse he is riding." ${ }^{11}$

Plato spoke of time as the 'moving image of eternity. ${ }^{12}$ It would seem as if time is indeed a fleeting phenomenon, constantly escaping our grasp, but also drawing us along in its wake. Time could be described from a multitude of perspectives, for example, philosophical, socio-economical, symbolic-anthropological, phenomenological, and developmental-psychological, etc., without us exhausting the fullness of its dimensions. ${ }^{13}$ Our understanding of time itself has developed

\footnotetext{
Tillich (1962:187) calls time and space the 'Hauptstrukturen der Existenz'.

In this regard, Tillich (1962:187) refers to the 'fundamentale Spannung der Existenz'.

Cilliers (2016a:6-7).

10 "Time - relentless, ever-present but intangible and the single element over which human beings have no absolute control - has long proved a puzzle to social anthropologists and sociologists as well as to philosophers." Gell (1992).

11 Priestley (1964:81). Seen from a negative perspective, our time is (literally) being eaten up by the chronophage (time eater), as depicted in the corpus clock designed by John Taylor. The clock was unveiled by Stephen Hawking on 12 September 2008, and can be viewed at the corner of the Taylor Library, University of Cambridge. A locust-like figure sits on top of the clock and seems to be devouring the seconds as they tick by - an indication that our time is constantly being threatened, and is in fact our enemy.

12 Cf. Burnet (1951:340).

13 Gell (1992). Piaget, for instance, did some interesting research on our understanding of time. According to him, children up to the age of six understand 'spatial time' only, that is, they can measure 'time' in terms of spatial changes or transferences (for instance, being in the bedroom or outside in the garden). Between the ages of six and seven spatial time becomes 'compartmental time', which means that children now measure time in terms of 'before' and 'after', or 'short time' and 'long time', although these pockets of time
} 
over time, with current astrophysical discoveries opening up breath-taking new dimensions of time. Paul Scott Wilson contends: "Any attempt to picture time is inescapably flawed, though greater richness is possible now in science where time is often pictured as being like a fishing net cast in space in embedding diagrams that depict space-time multi-dimensionally in the general theory of relativity." ${ }^{14}$

The notion of time is, off course, human-made; time does not really 'exist'. It is an idea, and was first mechanically measured during the $14^{\text {th }}$ century. ${ }^{15}$ Time could in fact be described as an evolutionary and genetically situated competence, a biological necessity for human beings to handle and 'organise' themselves in an ever-changing world, and to equip themselves for coordinating complex movements with other people, within the interconnectedness of community.' ${ }^{16}$ In this sense, even categories like anticipation and movement, could be linked to time. ${ }^{17}$ Someone like Aristoteles already understood that time is irrevocably connected to 'movement' - a notion that we will re-visit in this book. ${ }^{18}$

Different people and especially cultures view 'time' differently; there is something like 'chrono-geography' ${ }^{19}$ The so-called (western) modern understanding of time, has, for instance, been radically influenced by the 'protestant ethic and spirit of capitalism', especially during the $16^{\text {th }}$ and $17^{\text {th }}$ centuries, resulting, inter alia, in the now (in)famous slogan of Benjamin Franklin, one of the founders of America: 'Time is money. ${ }^{20}$ And, as time goes by, a variety of related slogans have made their appearance: 'slow time', 'time ecology', 'time culture,' 'time wellbeing' - not to speak about 'killing time.' This 'slowing down of time' seems to have become a fashionable trend. ${ }^{21}$

In his provocative book, Becoming Friends of Time: Disability, Timefullness, and Gentle Discipleship, John Swinton also calls for a type of 'slowing down' of time,

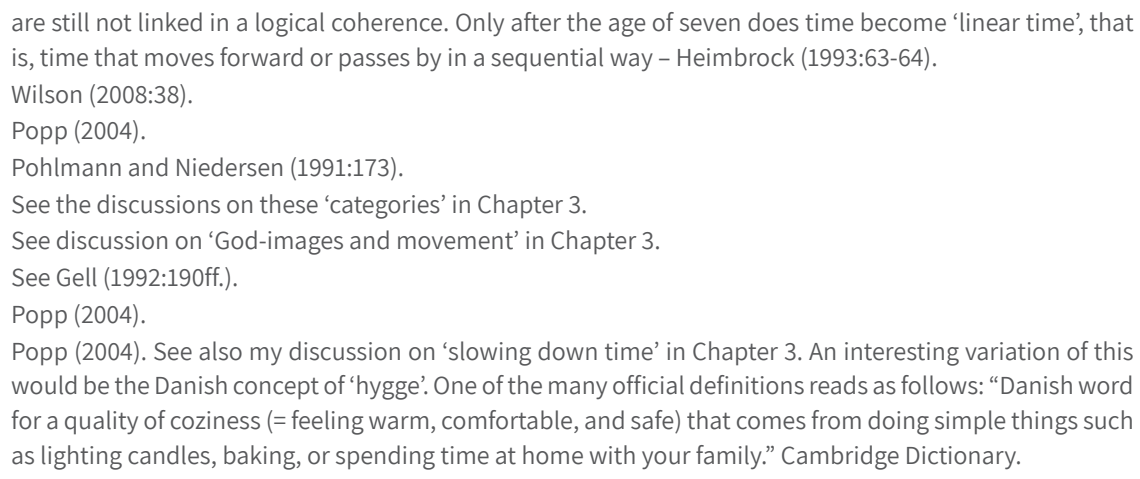
would be the Danish concept of 'hygge'. One of the many official definitions reads as follows: "Danish word for a quality of coziness (= feeling warm, comfortable, and safe) that comes from doing simple things such as lighting candles, baking, or spending time at home with your family." Cambridge Dictionary. 
but from a different angle. ${ }^{22}$ According to Swinton, our current clocks represent a development dating back to the Benedictine monks of the European medieval age - they created a system of bells to announce the schedule of the day. These bells therefore had a distinct meaning and purpose: "... to call the religious to spend time with God."23 Swinton argues that this original, socio-religious intention of 'time' has been devaluated to a mathematical system of minutes and seconds, that should not be wasted, under the pressure of economic performance. This has dramatically altered the nature of time itself: "Time had become a commodity that was judged worthy according to its economic utility and commercial instrumentality rather than its ability to shape, hold, form, guide, and sustain human faithfulness to God."24

In contrast, Swinton calls for a re-appraisal of time that also allows time (and space) for the handicapped, i.e. people who are perceived to suffer from 'temporal weakness', or who are considered a 'waste of time.25 Against this specific pastoral background, Swinton advocates that 'slow is the new fast' and that God's time is 'slow, gentle, and personal. ${ }^{26}$

It is quite clear that there exists no generally accepted definition of 'time'. On the contrary, as already mentioned above, definitions of time are as fluid as the diversity of cultures within which time is calculated, understood, and experienced. Time is intrinsically connected to the richness of the 'landscapes' of cultures. The Indian anthropologist Arjun Appadurai expanded the notion of landscapes, and speaks of five-scapes, each representing 'cultural dimensions of globalization. ${ }^{27}$ These five dimensions he calls ethnoscapes, mediascapes, technoscapes, finanscapes, and ideoscapes - all being 'dimensions of global cultural flows.'28

Thomas Tweed has transferred this notion to religion, and speaks of 'sacroscapes. ${ }^{29}$ These 'religious flows ... across time and space' every now and then come to a temporary standstill here or there. ${ }^{30}$ As such, they represent, and are connected to, local as well as global space and time. Although sacroscapes

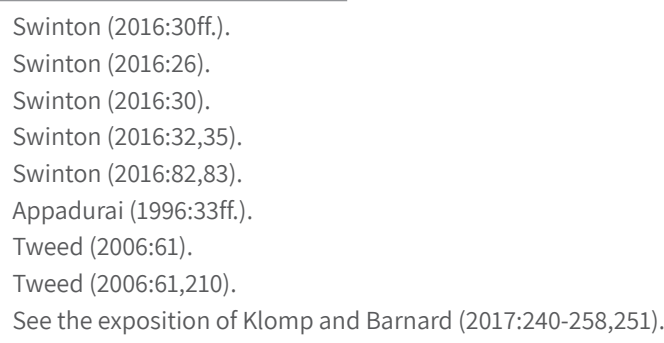


are inclusive of the traditional, institutional church, they can also, and perhaps primarily, be found outside the church. ${ }^{31}$

The 'religious understanding of time' is also, and has always been, in flux. So many sacroscapes, so many definitions of time. In this regard, I would venture to speak about 'sacro-timescapes'. Indeed, time flies, flows, is in flux. Time constantly 'escapes' our grasp - also those made from religious (and indeed homiletical) positions of imagined power. Preaching and Power have not always enjoyed a healthy relationship. Preachers seem to fall into the trap of power quite readily. ${ }^{32}$ Pulpits seem to be the spaces from, or on, which power can be pounded quite impressively. The flux of time, after all, fools and frustrates the passion for (fixated) power. ${ }^{33}$

The so-called postmodern worldview also brought new visions on the notion of time. It does in fact not differentiate between time-periods, i.e. epochs that could be described along a linear timeline, for instance from the Middle Ages to Enlightenment to Modernism to Postmodernism, etc. Instead of a before and after, postmodernism postulates a next to, together with, and against one another of the so-called periods of history. In other words, simultaneity is preferred, rather than perfect distinctions, especially if the latter are made in a hierarchical manner, from a position of power. According to this postmodern approach, the meaning of the here and now is not constituted by the period from which it developed, nor from a type of proleptic imagination of the period that is to follow. For its legitimacy, the here and now needs no before and after. In this regard, Utz Riese even speaks of a postmodern 'conversion of time. ${ }^{34}$

The debate about time is far from over. Key concepts that constantly seem to come to the fore, are those of 'cyclical and/versus linear time.,35 The distinctions drawn by Mircea Eliade in this regard, although not going uncriticised still prove to be helpful. ${ }^{36}$ According to him, the linear approach to time received its impetus from the eschatological traditions of Judaism and Christianity: time moves from a past (creation), via a present, towards a future, culminating in the restoration, or ultimate liberation, of creation. The coming of Christ,

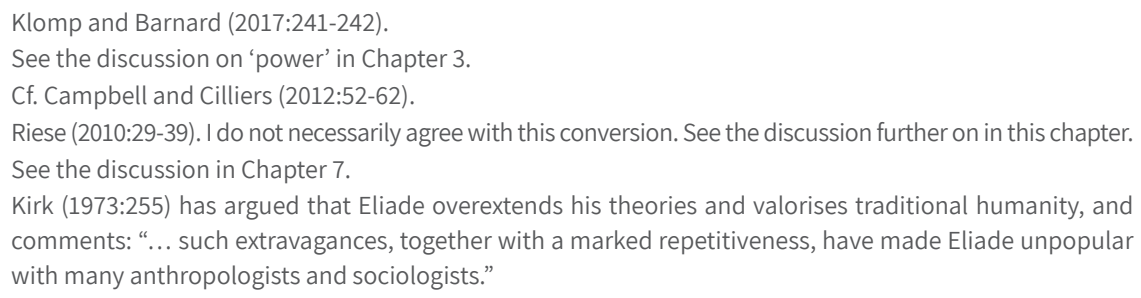


and outpouring of the Spirit, then would be decisive markers in the Christian tradition on this 'teleological route' from past to present to future.

This approach, which culminates in the divine dissolution of the fallen world, therefore can redeem time and consequently enable its adherents to transcend the catastrophes, military disasters, social injustices and personal suffering inherent in history - the 'terror of history' - by positing a metahistorical meaning. ${ }^{37}$ In this approach, redemption of time only takes place 'at the end' History as such, filled with terror, remains unredeemed.

The cyclical approach, on the other hand, often expressed through archetypical rites and rituals, sometimes also called mythic or a-historical time, seeks to 'transcend teleology' in order to avoid the terror of history. ${ }^{38}$ Humanity then becomes liberated from the remorseless unfolding of events in linear time. In this way, time can be regenerated and redeemed. ${ }^{39}$ Here, redemption of time can, and does, take place within history, even within the spaces and times of the terrors of history. (In this regard, I would postulate, the act of preaching could serve as a signal of transcendence, as an indicator of the light that gets in, through the 'crack in everything' - the words of the late, great musician, Leonard Cohen.)

Perhaps Cohen, well known for the Judeo-Christian influences in his music, did in fact have something like this in mind - surprisingly, given his seemingly pessimistic view on life as being a state filled with suffering. ${ }^{40}$ On the other hand, perhaps he could sing as follows not contrary to, but exactly 'on the grounds of', the unsolved question of suffering:

Ring the bells that still can ring

Forget your perfect offering

There is a crack, a crack in everything

That's how the light gets in. ${ }^{41}$

In this book, I propose that so-called unredeemable and redeemable time indeed need not be exclusive of one another. I contend that the act of preaching somehow contributes towards 'a redeeming of time within (to be) redeemed time.' Teleology need not exclude fulfilments of time, fulfilments en route to

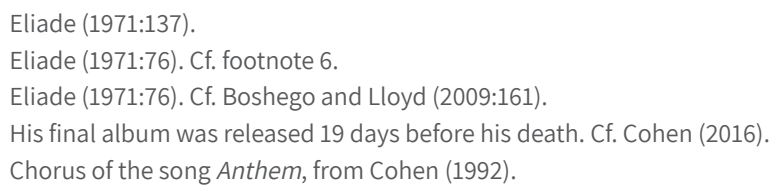


the telos. ${ }^{42}$ Preaching creates (cyclical) moments in (linear) time that could be called Kairos, and Pleroma. ${ }^{43}$ An interesting poem by T.S. Eliot illustrates this:

Time present and time past

Are both perhaps present in time future

And time future contained in time past.

If all time is eternally present

All time is unredeemable. ${ }^{44}$

At first glance, it seems as if Eliot proposes a somewhat deterministic conclusion about time and history, stating that 'all time is unredeemable. At closer look, we see that Eliot places a condition on his deterministic statement, with the words 'perhaps' and 'if'. In terms of the grammatical construction, at least, we have a conditional proposition: 'if' past and present are fused in an eternal present, 'then' the present is eternally determined by what happened in the past. ${ }^{45} \mathrm{Or}$, in other words: 'perhaps time' could be seen and experienced as deterministic - but need not be. The deterministic onslaught of time 'can' be redeemed. Following this line of thought, I propose that preaching 'can' open times and spaces, where 'perhaps' and 'if' are lingering in such a way, that time could be experienced as 'redeemed. ${ }^{46}$

In this book I do take cognisance of a (homiletical) understanding of linear time (also called 'monochrome time') - moving from the past to the present to the future. ${ }^{47}$ Time flies (tempus fugit), but it never flies backwards; it always flies forward - at least, as far as some of us understand and experience it - and it has been doing so, according to some calculations, for the past almost 13,8 billion years. Or, to add the (9) zeros, for the sake of visual oversight: 13,8000000000 years - that is a long list, and a long time.

\footnotetext{
See discussion on 'fulfilled' time in Chapter 7.

See discussion in Chapter 3 and 7.

"Burnt Norton" from The four quartets, Eliot (1962:175).

Cf. Boshego and Lloyd (2009:175).

See the discussion on 'grace' in Chapter 2.

Traditionally speaking, this (linear) understanding of time has been significant for our understanding of for instance the Christian liturgy. Barnard and Vos is of the opinion that it is not cyclical time, but the church year, even more so the weekly rhythm of seven days that structures the encounter between God and God's people in time. He concludes that the rhythms of night, the seasons, and certain festivals are determined by the courses of the planets, i.e. they are cyclical. They keep on returning; their times follow cyclical, cosmic laws. However, the week and the hour are not mirroring a cosmic cycle. Also, not of the moon-one moon month is about 292 earth days. The week and the hour are not images of a cyclical period, but of continuous, i.e. linear time, of history that is headed somewhere, and will end on God's great Day, the eighth Day. This book, however, while accepting the fundamental importance of the (traditional) understanding of the church year and calendar, does not focus on these perspectives; rather on a distinct understand of 'now'. Barnard and Vos (2001:17-32).
} 
Yet, I do not exclude the notion of 'cyclical time' (also called 'polychrone time'), in which the emphasis falls on the recurrence of times and events, for instance night and day, summer and winter, etc. ${ }^{48}$ On the contrary, when brought into a specific relationship with linear time, cyclical time offers profound impulses, in particular for homiletics. As a matter of fact, I do believe that the strict distinctions often being made between linear and cyclical time represent a false alternative; therefore I will be proposing a 'spiral understanding of time' - seeing that a spiral probably represents the best result, at least in terms of imagery, when a line and a circle are combined..$^{49}$ This spiral imagery, combined with a communal dimension of temporality, could be called 'spiral-communal time' (communis spiralem tempore)..$^{50}$

My acceptance of the notion of linear time, furthermore, comes with the provision that the relationship between the 'times' (past, present, future) is understood in a dynamic, one could say, fluid way. This means that, although past, present and future could be understood as 'separate' tenses or stages of time, they are also 'intrinsically intertwined. For us to understand the present (hic et nunc; here and now), we need discernment (phronesis). This entails inter alia the incorporation into the present of both the past by way of remembrance (anamnesis), as well as the future by way of anticipation of its coming (adventus). ${ }^{51}$

(If we look closely at the present, we will indeed see the past and the future in it.) It is not wise (i.e. against phronēsis) to cast out or cast off the past and/or the future from the present. We are reminded of the words of Karl Barth, quoting Calvin in the introduction to his book, The Theology of John Calvin, that we should learn from history "... on the simple grounds that we humans are not oxen and asses that know only the present but have a reason that embraces things past and things to come. We have, then, a sense of time".52

If the flow between the times is misunderstood, i.e. if we lose our 'sense of time', it may, in my opinion, result in several misconceptions of past, present and future, some of them in fact being ideologically quite dangerous. Then the tenses of

\footnotetext{
48 Cf. Popp (2004).

49 This is of course nothing new ... "Time for medieval man, especially the rural peasants, could be said to have had a spiral formation, thus combining both cyclicality and teleology." Boshego and Lloyd (2009:159).

50 Perhaps this take on time resembles the time zero referred to above (when linear time becomes too small to measure), and the infinitely large ball (a circle wherein community flourishes)? A spiral-communal time that does move forward, but based on a communal experience, within the circle of 'now'? See the discussion in Chapters 3 and 7.

51 See the discussion in Chapter 3.

52 Barth (1993).
} 
time (past, present, future) become compartmentalised; become autonomous 'pockets' of time. History then becomes historicism, which entails a type of 'monumentalization' of time. Future becomes futurism, which signifies that time becomes 'apocalyptic'. In turn, the present is solidified into presentism, which inevitably results in our understanding of time becoming superficial.

This understanding of the relationship between past, present and future is of the utmost importance - especially also for preaching. This book is, inter alia, about the linking and connecting of past and future in, and to, the present (the 'now') - in and through the act of preaching. This linking and connecting could be called 'timing'. In this book, I propose a few perspectives on timing, on what I would like to call 'the timing of the grace of the present'.

It is important to state here that the notion of timing, which forms the leitmotiv of this book, should be understood as a 'qualitative category', and not in a quantitative sense. To put it briefly: in what follows, I will constantly be looking at the quality of the 'now', as it becomes apparent in a variety of sermons. It will also become clear that this quality of time, of the 'now', in distinction to, and in conjunction with, the (mathematical) duration of time, could and should be understood on different levels.

First and foremost would be the notion of 'timing as pre-sencing', i.e. as the sensing of a Presence in the present. ${ }^{53}$ 'Pre-sencing' integrates three key concepts in this book, namely sensing (i.e. discernment, as phronèsis), presence (i.e. God's Presence, as coram deo), and present (i.e. as 'now'). Pre-sencing could be described as follows:

Presencing shifts the place of perception to the source of an emerging future whole - to a future possibility that is seeking to emerge ... Presencing is a blended word combining 'sensing' (feeling the future possibility) and 'presence' (the state of being in the present moment) ... The boundaries between three types of presence collapse: the presence of the past (current field), the presence of the future (the emerging field of the future), and the presence of one's authentic Self. When this co-presence, or merging of the three types of presence, begins to resonate, we experience a profound shift, a change of the place from which we operate. ${ }^{54}$

See the discussion in Chapter 2.

Kempen (2015:140-141). Also according to Louw (2019): "With 'presencing' is meant a kind of encounter wherein past, present and future intersect in such a way that sensing (experience) and present moment (state of being) coincide in such a way that a linear understanding of time makes place for circularity and a spiral interpretation. Presencing is about the 'opening of the human mind' (significant reflection) and the 'opening of the heart' (wisdom). It implies the paradigm shift from analytical causative thinking to 
Pre-sencing, i.e. timing of the 'now' could furthermore be seen as the 'linking and connecting' of (past, present, future) times, as stated above, But timing could also be understood as an 'act of intersecting', in the sense of overlapping of the (past, present, future) times, but also of linear and cyclical time, as proposed above. But, at the same time, timing also constitutes an 'osmotic event', in which the fluidity and reciprocity of these times become evident. ${ }^{55}$ And, as I will be advocating, this 'timing of, and as event (happenstance), always carries within itself, the 'dimension of interruption' ${ }^{56}$

Obviously, I will not, indeed cannot offer any conclusive exposition on the notion of 'time'. As I am not an astrophysicist, I am also not an expert in the 'anthropology', or 'philosophy' of time. Nonetheless, I comfort myself with the knowledge that, until the present time, nobody has been able to explain in a satisfactory manner, what 'time' is or means. ${ }^{57}$

As this book is about preaching, I will exemplify what at least I understand under the notion of time as 'now', by looking at some South African sermons. These sermons could, on the one hand, be described in terms of a 'mistiming of the grace of the present', and on the other hand, as sermons that seemed to express something of the art of timing - the latter from well-known South African preachers like Allan Boesak ${ }^{58}$, Desmond Tutu, and Beyers Naude.

All these examples play out against the backdrop of the time of apartheid, the transition to democracy, and the so-called post-apartheid times - sad, and moving, and inspiring moments in our history. These moments (that could be called 'now', in retrospection), will continuously form the lens through which I will be looking at these sermons. I also felt compelled to add a section on the importance of preaching on 'ecological issues', in particular 'now', not only in (post-apartheid) South Africa, but indeed globally.

integrative circular thinking. In Old testament thinking, presencing refers to the notion of fellowship with God - coram Deo."

55 See the discussion in Chapter 3.

56 See the discussion in Chapter 4.

57 "Bis heute konnte aber niemand befriedigend erklären, was den die Zeit eigentlich ist." Pohlmann and Niedersen (1991:169).

58 Allan Boesak, a well-known South African preacher articulates his aversion of pietistic traditions and preaching in the church in no unclear terms, stating that "this kind of theology is often the handmaid of authoritarian structures that preserve the status quo within the church, with the result that the church is being held back to an era that has irrevocable passed." For Boesak the gospel - and preaching - is about 'this' world, not an 'other-worldly theology'. Boesak (1979). See the discussion on 'Boesak' in Chapter 4, as well. 
Off course, with the reading of any text always comes certain limitations, one of them being the 'temporality of orality'. Words (and sounds) are bound to time. Words fly, as time flies; they cannot be frozen, or reversed. Texts, on the other hand, transcend this temporality of orality, giving us time (!), to repeatedly re-hear the sound, or at least, re-read the words that originally created the sound. ${ }^{59}$

Because of the nature of the sermon examples that I will be referring to (whole sermons, citations, longer excerpts, taken from the different time-periods mentioned above), I will be making use of a variety of methodologies of sermon-analyses, changing the methodological gears from time to time, so to speak..$^{60}$ In the light of the analyses, I venture some perspectives on the role of the Biblical text as a timed and timing text, that needs to be (hermetically) timed, instead of (moralistically) tamed. I conclude by going back to the notion of African Time, in which the present (now) indeed is 'timed' in terms of the past and future in a distinctive, and in my opinion, helpful way in view of preaching.

One further preliminary note is necessary: as mentioned above, this book about time was written in tandem with my book on space. ${ }^{61}$ It is therefore inevitable that some cross-references will be made, from time to time. Because of this interconnectedness, but in particular also because of the impossibility to attain a full grasp on the idea of 'time', this book will again be looking at the latter through the 'lens of aesthetics'. In A Space for Grace, I said the following:

Speaking more broadly, it could be said that the idea of 'aesthetics' - of which space forms a fundamental constituent - forms the golden thread that runs throughout this book ... Preaching, in my opinion, entails more than just speaking, hearing and (cognitive) understanding. It calls for a multi-sensory (re)discovery of space and time, within space and time. ${ }^{62}$

59 Cf. Joubert $(2004: 18,23,44)$.

60 On the advantages of using a variety of practical theological methodologies, see Ganzevoort and Roeland (2014:91-101).

61 See the Preface.

62 See Cilliers (2016a:5-6). The notion of aesthetics is often equated with a certain misunderstanding of beauty. Many views 'beauty' through a haze of romanticism. For them, beauty is all about objects (or experiences) that are fine, excellent, noble and honourable. Beauty is then nothing more than merely evoking a sentimental feeling about pretty sunsets and artistic flower arrangements - or perhaps saying: 'Thank you, it was a beautiful sermon.' Others interpret beauty exclusively in terms of corporeal and even hedonistic and narcissistic trends: Beauty becomes a slogan for 'lifestyle' advertisements and cosmetic make-overs. The relationship between the proportion of order and the disproportion of chaos is important for our understanding of beauty. Disproportion of chaos is not the deformity of proportionate order. Chaos is something in itself - as is order. The link between these two realities could be described as beauty. Beauty exists in the tentative space between proportionate order and disproportionate chaos. 
Aesthetics will indeed again act as a type of conduit in this book towards a 'multi-sensory (re)discovery of space and time, within space and time'.

Therefore, I think it is about time that we look at two artworks, about time.

\section{Time ... in concrete?}

Few artists have captured our quest to understand time in a more fascinating way than Arthur Ganson. He is known for his kinetic sculptures, making use of his engineering skills and knowledge - entitling many of his artworks with the phrase: Machine with ... ${ }^{63}$ He calls one of these sculptures, created in 2009, Machine with Concrete. ${ }^{64}$

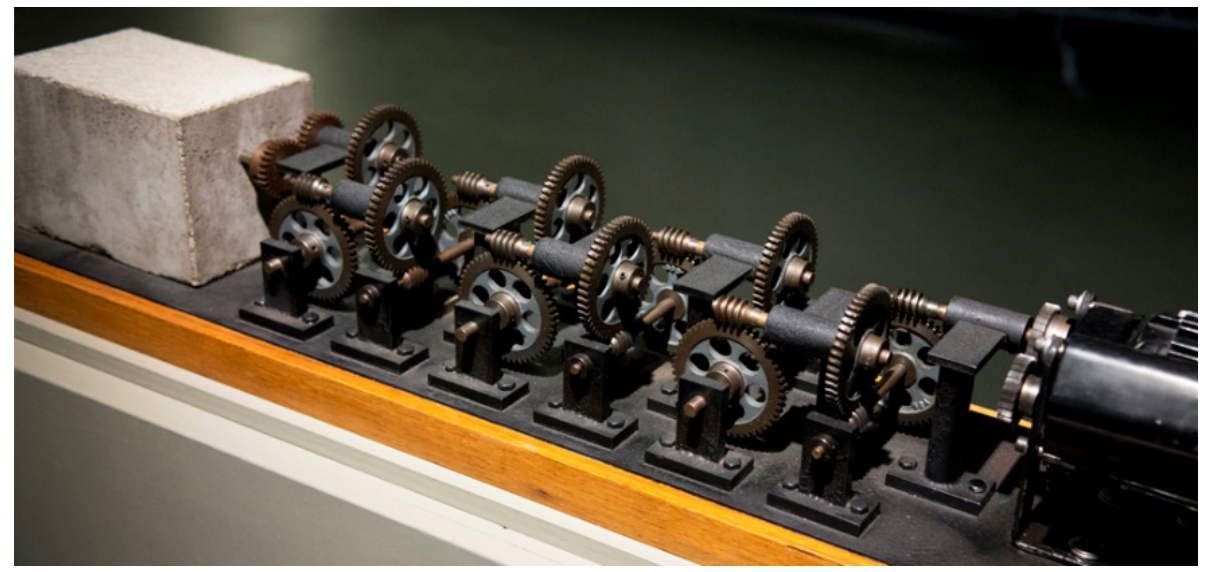

Figure 1.1 Arthur Ganson's Machine with Concrete (1992) (Ganson, 2009)

So, is this what time looks like? A very long line of levers, bolts, and screws turning and turning for a very long time, and then - nothing? Is history indeed unredeemable, with no telos, no outcome, no fulfilment? No redeeming of

The quest for beauty is sparked off by this tension; it is perpetually energised by the movement from disproportion to proportion, i.e., from chaos to order. Understood in this sense, beauty therefore does not exclude the ugly (or disproportionate), but in fact incorporates it in its quest for (healing of) proportion. The very existence of the tension created by disproportion kindles a faith that is in search of beauty (fides quaerens pulchrum). In a sense, this book is about the search for 'beauty', as also articulated in preaching. Cf. Cilliers (2011a:257-266). Both space and time are, of course, complex concepts. According to Newton-Smith (1989:24), this “... problem arises from the 'promiscuous' character of the notions of space and time. These concepts are so intimately connected with such a wide range of fundamental ideas that the prospects of finding some unproblematic terms with which to define them are dim."

63 Some of these titles are Machine with 23 scraps of paper; Machine with Wishbone, etc.

64 It was displayed for the first time in the Art Electronica Museum of Future.

65 In Ganson (2009)'s words: "Intense activity on one end, quiet stillness on the other ... It's a duality I feel in my own being." 
the 'terror of history', whatsoever, whenever? Does tick-tock simply end up in a block?

If this was true, time is (literally) screwed ... in concrete.

Let us leave this one open - for the time.

\section{It is a matter of cheese ...}

Obviously, in a book about time, the iconic artwork of Salvador Dalí, The Persistence of Memory, or Melting Clocks (1931), simply 'must' make an appearance. ${ }^{66}$

This painting by surrealist artist Salvador Dalí could arguably be called one of the most recognisable pieces of art of the twentieth century. The dominant elements in the painting are four distorted; seemingly melting clocks in an otherwise empty desert scene - the latter probably a reference to Dalís own beachfront hometown of Port Lligat, a barren and infertile landscape.

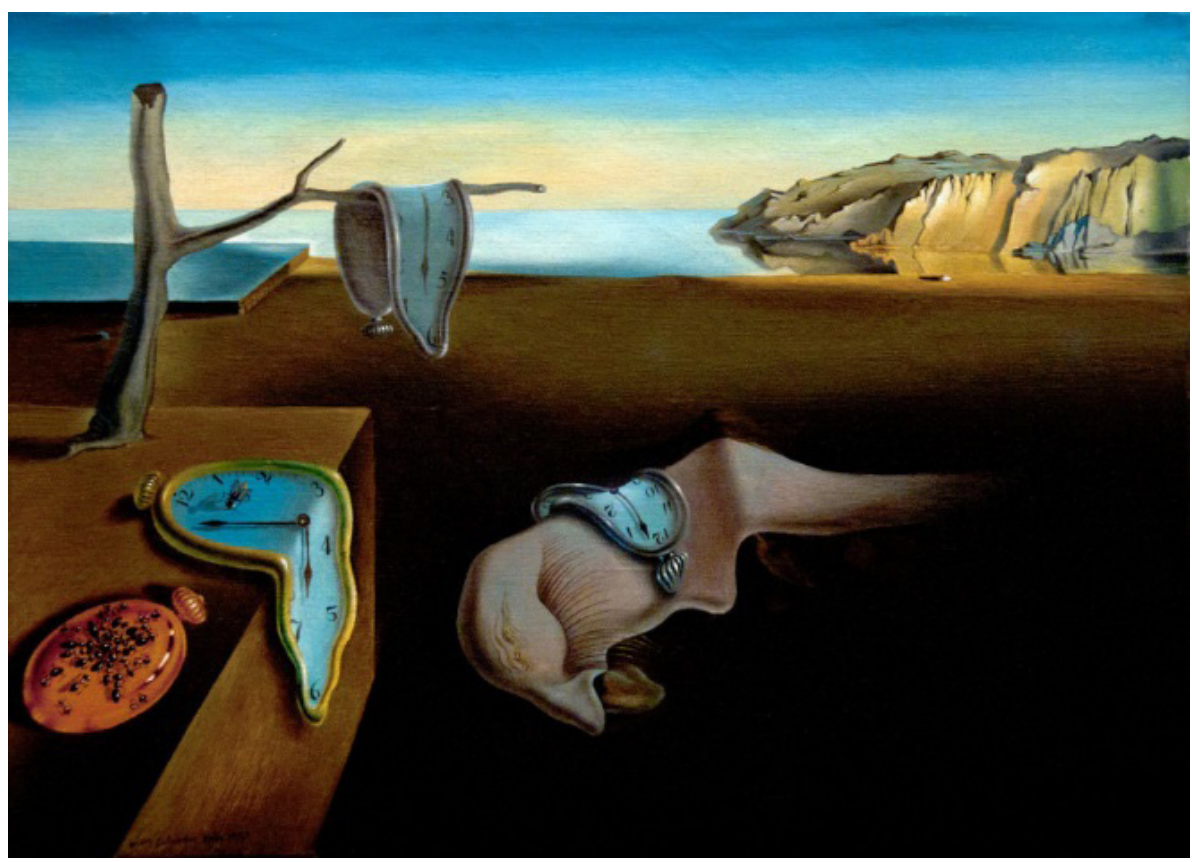

Figure 1.2 Salvidor Dall's The Persistence of Memory (1931) is an oil on canvas painting and hangs in the Museum of Modern Art in New York (Dalí, 1931)

66 In Cilliers (2016a), I wrote extensively about the historical background of surrealism, which will not be repeated here. See Cilliers (2016a:110-113). For a good overview of this history, see Hopkins (2004). 
It is not easy to interpret this work of art, and probably Dalí intended it to be that way. Most art critics would agree that the idea of 'dreaming' is integral in understanding Surrealism and probably plays a key role in the meaning of The Persistence of Memory, as well. ${ }^{67}$ The mysterious, not easily describable figure that appears to be sleeping underneath one of the 'melting' clocks is thought to symbolise the warped and erratic passage of time that occurs in one's dreams. ${ }^{68}$ We all know that watches do not normally look like this, on the contrary:

They are rather rigid objects, signifying that (our understanding of) time is set and cannot be altered. Time cannot be bent - at least not in our earthly experience of it. Therefore, we are victims of time; we are pulled along in its wake. Time waits for or obeys no one. Tempus Fugit - time flies; constantly escaping from our grasp. It indeed seems as if time governs our lives, every minute detail of it, whether we accept it or not. ${ }^{69}$

It is possible that Dalí intended to illustrate how 'soft' our concept of time is inside the dream state - in contrast to the experience of 'hard' time in the awake state. During our daily lives, we are 'driven' by timeframes, deadlines, calendars, appointments, etc. Using the imagery of melting clocks, Dalí might be saying that our notions of time have become primitive, old-fashioned and even impotent in a post-Einstein world.

Some interpretations of this enigmatic work of art indeed propose that it resembles an astrophysical understanding of time. Time is then viewed as pliable and no longer as rigid or deterministic - following the curvature of space towards space-time. ${ }^{70}$ However, it has also been pointed out that Dalí did not necessarily have notions of astrophysical space-time in mind when he created his melting clocks; rather the impression which camembert cheese, melting and dripping in the sun, made on him. ${ }^{71}$

Butler, Van Cleave and Stirling (1996:506).

Butler, Van Cleave and Stirling (1996:116).

Cilliers (2016a:111-112).

We are even reminded of Richard Dawkins' notion of 'unmeasured' time. Cf. Chapter 1 , footnote 5.

Dali's melting clocks are one of the most characteristic and original images of the artist's visual world. He painted them in, The persistence of memory. The Dalínian clocks are linked to two concepts: the relativity of time and the aesthetics of soft and hard objects. Salvador Dali expressed his contempt for the amorphous and his fondness for hardness on several occasions. He claimed that his soft clocks were in fact nothing more than soft camembert cheese, dripping and outlandish. Dali declared that the vision of melting cheese is, in fact, the most perfect definition that the very highest mathematical theories could provide for the space-time concept. See Dalí (1931). 
It is also a known fact that irony plays an important role in Surrealist art. ${ }^{72}$ The title of this artwork, Persistence of Memory indicates the opposite - our (traditional modes of) memory are losing their hold on our lives. They are literally melting away, being anything but 'persistent'. The title should in fact have been 'Non-persistence of Memory'. Perhaps the added detail of ants eating away at the face of the red clock indicate the transient and arbitrary nature of our modes of keeping time.

So, is time set in concrete, or made of cheese? Is it hard, or soft? Redeemable, or unredeemable? Does it fly away like a bird, or can it be reined in?

Keeping this in mind let me try and saddle this magic beast called Time, again. 


\section{SERMON: MY TIMES ARE \\ IN YOUR HANDS ...}

Into your hands, I commit my spirit ... My times are in your hands ...
PSALM 31:5,15

If you find yourself in the city of Hiroshima in Japan on 6 August of any year, you will witness a remarkable ritual. At precisely 8:15, the bells all over the city begin to ring, and everything and everyone come to a standstill. Vehicles stop immediately, and drivers sit behind their wheels with bowed heads. Everywhere, in skyscrapers and restaurants, on streets and in parks, people pause where they sit or stand. For the outsider, it would seem as if the entire city has fallen under a kind of mass hypnosis, or suddenly gone into deep meditation.

What is this? These people commemorate another $6^{\text {th }}$ of August, call another 8:15 into remembrance, a day and an hour that can be described as one of the darkest dates not only in the history of the city, but in the entire history of humanity: 6 August 1945 at 8:15, when an atom bomb exploded above the city, in one insane moment obliterating some hundred thousand people and dooming thousands of others to death by radiation or mutilation. When the inhabitants of Hiroshima stand silently with bowed heads, it is because they look at the clock and remind one another, remind the whole world: Such an hour may never, never come again in the history of any city or humanity. Never.

Who, or what, determines what happens when and to whom on this earth? We all wonder - consciously or unconsciously. Perhaps you are wondering right now. If you think back and remember a day or an hour - what exactly filled that day or hour with such grief? Fate? Luck or misfortune? Was it simply the second when the hourglass of your joy ran out? Was it the result of the ineptitude or evil intentions of others? Or, even worse, was it the bitter poison of your own guilt that caused this terrible hour to break for you? Who, or what, holds time in its hands?

The poet of Psalm 31 also wonders about this. As with many other psalms, we do not know what the historical background to all his questions was. What 
we can deduct from the psalm, is that he feels threatened by many enemies surrounding him, a threat that has broken him, emotionally and even physically. Totally disorientated he calls out:

Be merciful to me, Lord, for I am in distress;

my eyes grow weak with sorrow,

my soul and body with grief.

My life is consumed by anguish

and my years by groaning;

my strength fails because of my affliction,

and my bones grow weak.

Because of all my enemies,

I am the utter contempt of my neighbours

and an object of dread to my closest friends-

those who see me on the street flee from me.

I am forgotten as though I were dead;

I have become like broken pottery.

For I hear many whispering,

"Terror on every side!"

They conspire against me

and plot to take my life. ${ }^{73}$

At first glance it seems as if his enemies have determined his fate, that they hold the entire course of his life, his days and hours, in their power. But, what does he confess? One of the most moving and well-known pronouncements in the Scriptures:

But I trust in you, Lord;

I say, "You are my God."

My times are in your hands ... ${ }^{74}$

These 'times' that the psalmist is referring to would probably not only indicate the lifespan of the psalmist, but also the events that fill up this lifespan. Martin Buber, a well-known Jewish Old Testament scholar translates this: My hours are in your hands. From the smallest part, to the greater framework of my earthly time, are in God's hands. The next second, the next time I blink my eyes, or my heart beats, or I breathe, are in God's hands. The next hour, the next day and night, the next winter, spring, summer, autumn, are in God's hands - and all the events that will come to pass in these times and seasons. My term hours, exam hours, class hours, work hours, the dates circled in red on 
my calendar, the inscriptions in my diary, the deadlines ... are in God's hands. The times of suffering and the times of prosperity, the years of my youth and my old age, the time of birth and the time of death, past, present, future and end-time - unto eternity - are in God's hands.

No, our times are not in the hands of fate, or our enemies, or our enemy, called Evil. This is the age-old, seemingly unsolvable paradox: It 'is' evil that lifts the dagger, pulls the trigger or presses the button of the atom bomb, bringing about my last second on earth - and yet it is 'not'. My times are 'not' in the hands of powers beyond my control. It is even not in the hands of my own deadline-driven programme - as impossible as that may seem to many of us. Our times are, thank God, not in our hands. Our times are in God's hands.

Of course, one can understand this wrongly. You could argue: Well, if it is true that the next second and the next blink of an eye is programmed and predestined, what is the point of opposing it? Who can climb up to the heavens and turn the giant hand of God's clock forward or hold it back by one millimetre? What will be, will be, and who can prevent it? Of course, we 'can' think like this, but then we become mere marionettes of some divine clockwork - doomed to listen to the tick-tock of God's clock, awaiting our hour, with a dull resignation, succumbing to a deadening fatalism. Then our time will, in the end, be screwed in the concrete coffin of death.

If you read the psalm like this, you are missing the wonderful balance that characterises the whole structure of the psalm. Because right at the beginning another, equally moving and well-known confession, rings out: "Into your hands, I commit my spirit [that is lifespan, time, hours]." ${ }^{\text {T5 }}$

Note: my time are in God's hands; but I also surrender my time into God's hands. What stands fast, awakes the prayer for the steadfast, in the poet. That which is a fact, creates in him the longing for the fact. No wonder that we repeatedly hear the poet crying: "Lord, deliver me ..." But then in the same breath and with full certainty: "You have delivered me ."76

This is the essence of prayer, a prayer with which we can live and die, and a prayer that fits every time slot of our existence. If we were to enter the house of an orthodox Jewish family on the set prayer hours, we would find the children on their knees, and on the hour hear them murmur: "Into your hands I commit

Psalm 31:5

76 Cf. Psalm 31:2,5,6. 
my spirit." If we could somehow be transported to the deathbeds of numerous believers through the ages, we would hear these last words on the lips of many of them: "Into your hands I commit my spirit." Polycarp, John, Huss, Melanchthon, and many others said this with their last breath.

Yes, let us do some time travelling, now - back to the future. 'Back': We become part of the crowd on Golgotha, witnessing the crucifixion of the 'King of the Jews', at three o'clock in the afternoon. We see him taking his last breath. We hear him cry: “... Father, into your hands I commit my spirit," Luke 23:46. When the atom bomb of God's judgement explodes over His and our heads, He gives his times, and there with our times, into God's hands. 'Future': He, the very same King of the Jews, is with us, all the days until the end of time, Matthew 28:20. As King of Eternity, 1 Timothy 1:17.

Have we even begun to understand this? Our times are in God's hands; so, for Jesus' sake, give your times into God's hands. Do this going into a new day or week, when you must deal with a difficult situation, when the times in which you live, distress you. When you are frightened, consider this: the same hands that made a thousand million galaxies, which placed our planet in our milky way as a speck amongst millions of other stars, also hold you. The same hands that created the delicate wings of a fly and the curved beak of a falcon, that placed the bulky mountains on their foundations and created the endless blue sky with its cumulus clouds ... hold you in their palms.

And, as if that is not enough, just to be 'sure' that we can never slip out of God's grip, to guarantee that nobody and nothing can ever pluck us from these hands, God sends his Son to wrap his hands around us; his wounded, saving hands - even in this present, this 'now'.

Karl Barth, the famous Swiss theologian, once wrote in a sermon about Psalm 31:

Does God have hands, you ask? Yes, God has hands, and completely different, much better, far more dexterous, much stronger hands than these claws of ours. But, what do God's hands mean? Let me first put it like this: God's hands are his deeds, his works, his words, which, whether we know or want it, embrace, carry and hold us from all sides. But it can also be understood symbolically. However, there is a point where the symbolic ends, and the matter of God's hands become serious words, there where all deeds, works and words of God have their beginning, progression and goal: God's hands are the hands of our Saviour Jesus Christ. They are the hands he held open wide when he called: Come to me, all you who are 
weary and burdened, and I will give you rest. They are the hands with which he blessed the children. They are the hands with which he touched and healed the ill. They are the hands with which he broke bread and shared it with five thousand in the desert, and with his disciples shortly before his death. They are ultimately also the hands that were nailed to the cross for the salvation of all. My brother and sister, these are the hands of God: the strong father hands, the good, soft, gentle mother hands, the true, helpful friend hands, the merciful God hands in which we and our times are safe and secure ...

God said no-one will pluck you from my hands. We cannot hear this enough: nobody, no person, no angel and no devil, not even my own sin and death. Nobody can pluck me from God's hands. In these God hands, I am secure, I am lifted, I am saved.

We do not know exactly what our diary or calendar holds for the next moment, hour, days, weeks, months, and years. In fact, we do not know how many hours we have left in this world. What we do know, however, or should know, is that we may bow our heads in silence and look at our watches - not only to remember the dark hours of yesterday and the day before, but in recognition of the Giver of all our hours, in prayer to the Father of our time, in devotion to the One who is, who was, and who is to come. ${ }^{77}$

Listen.

Do you hear it? The bells that call us are ringing clearly.

Ring the bells that still can ring ...

Forget your perfect offering - to Time-driven, King Commodity.

Listen.

Was the time to put our time in God's hands, ever more at hand than now? 


\section{Chapter 2}

\section{TIMING GRACE}

Until now, the notion of 'now' has repeatedly come up. Let me say something (homiletically) about 'now'

Preaching is, inter alia, about what to say to whom, when. It is about the art-one could also say timing - of connecting the gospel (what) to the audience (whom), at a specific moment in time (when). ${ }^{1}$ Preaching could have a good content, even sounding like the gospel (what); it could be seemingly addressed to the relevant people (whom) ... but it could miss out on the 'now', i.e. on the timing (when). Sobering thought: preaching might sound sound, even spectacular or popular ... but it could still be false. The 'right' content, delivered to the 'right' people, but it does not fit into the 'right' time. Indeed, preaching might sound 'correct', but still be 'wrong'; in fact, it can be 'so' correct, that it is 'so' wrong ...

Or, the other possibility is that wrong timing (when) may also affect, indeed pervert either the what, or the whom, or both. Often, wrong timing needs and creates its own message (what) and constructs its own audience (whom). The what, whom, and when in preaching need to be in sync, and perhaps timing (the when) is the most important 'homiletical synchroniser'. It is, after all, about syn-chronos; about timing (or: tying) truth together with, and to, the addressees of this truth - always 'now'

Søren Kierkegaard says this in his own, inimitable way:

Today is born for you the Saviour - and yet it was night when He was born. It is an eternal image: it had to be night - and yet it became day in the middle of the night, when the Saviour was born. Today is an eternal time indicator, like when God says: Today; and like books that are published 'in this year'. It repeats from generation to generation, for every single

This is true of all preaching, but, as I will be contending in this book: it is true of what could be called 'prophetical' preaching. I know that the notion of 'prophetical preaching' can be understood in a number of ways, and, in my opinion, even has been devaluated and sensationalised to some extent, or viewed as an anachronism. In this book, I am using this concept in view of its 'interruptive dimension'. For a detailed discussion on 'the (Old Testament) concept of prophetical proclamation', see Brueggemann (2003:74ff.). See the discussion on 'interruption' further on in this chapter. 
being among these millions - and every time someone truly becomes a Christian, it rings out: Today is born for you, your Saviour. ${ }^{2}$

In this book, I will be reflecting on the significance, the quality of this 'today', this 'now' - not only related to the what, and whom, but also in its interconnectedness to past and future. ${ }^{3}$ Preaching, although it cannot take place without the past and the future, always happens in the present; more than that: it is an event that co-creates the present as presence. Past and future converge to form present, as a Presence. ${ }^{4} \mathrm{As}$ I argued elsewhere, time cannot be understood without space, and vice versa. ${ }^{5} \mathrm{~A}$ presence can only be experienced in a space; and this space is always linked to a time. A 'space for grace' always calls for, and always is constituted by, the 'timing of grace, i.e. the pre-sencing of a Presence in the present.' ${ }^{6}$

For me, timing, i.e. homiletic synchronising, is indeed linked to (in sync with) 'grace.' Grace has its own time, and indeed timing. It cannot be scheduled, manipulated, or choreographed - homiletically, or otherwise. Grace happens - therefore it is called 'grace'. In terms of (biblical) temporality, grace could also be called Kairos. Theologically speaking, Kairos indicates a fullness of time; a specific time in which God's intentions with this world is fulfilled. The Christ-event signifies the ultimate Kairos, as the Timing of an Event that embodies all of God's revelation. ${ }^{7}$

Timing grace presupposes 'discernment' (phronēsis), indeed: to know what to say to whom, when - within the context of community. ${ }^{8}$ It entails reading and interpreting the time(s) right, expecting the advent of an event within a specific moment in time. Timely preachers know and acknowledge the Kairos when it comes. More than that: these preachers help to kindle the Kairos. Herein lies the brilliance of the wisdom of preaching.

However, not everybody (preachers as well as audiences) understands and discerns the moment of Kairos when it comes. Some would even label it as a 'futile and foolish act' to give any attention to the advent of this (often seemingly elusive) event - seeing that it may not be the popular or spectacular

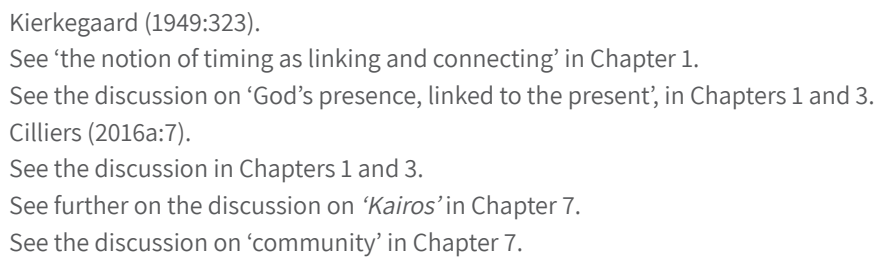


thing to do. It may even 'be seen as' highly unsettling and interruptive. ${ }^{9}$ Still, this act of discernment is wisdom, par excellence - even though we may call it 'wise foolishness.'10

This stands in stark contrast to what Karl Barth once had to say about the 'brilliance' of 'unwise foolishness':

Foolish people are always either too early or too late. They sleep when they should be awake and are awake when they should sleep. They remain silent when they should speak and speak when it would be better to remain silent. They laugh when they should cry and cry when they should be comforted and could have laughed. They work when they must pray and pray when only work could make the difference. They consider everything at the wrong time; say everything to the wrong people; do everything in the wrong direction; always choose the complicated but irrelevant things, while the simple but crucial are required. Herein lies the brilliance of foolishness. ${ }^{11}$

Brilliant, but unwise fools miss the point (of time); bypass the Kairos of the event. But, when this happens, time loses its fluidity and becomes solidified. Time (now) then does not become a space for the event of the gospel, but rather an enclave that should safeguard the eternity of our own convictions and agendas. What preachers need, indeed, could be called a 'theology of the event', to borrow a phrase from Caputo. ${ }^{12}$ Timing opens up a new experience; leads to a new event. ${ }^{13}$ The gospel and preaching thereof should never be 'monumentalised', or 'pillarised' as Postma describes it. ${ }^{14}$ Once preaching and in particular, God-images are changed into safe and secure certainties, or institutionalised enclosures or enclaves of the 'truth', and no longer is understood and experienced as events of encounter, it becomes time (!) for timely preachers to step in. ${ }^{15}$

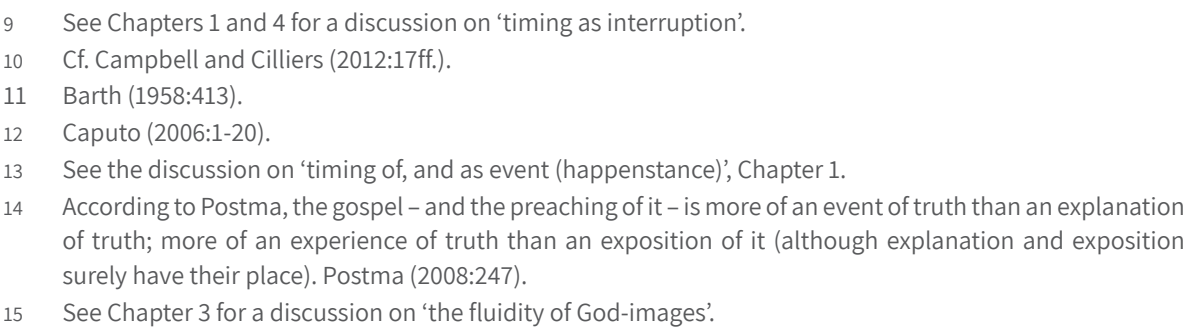




\section{Time for improvising...}

For this, there exists no recipe, or quick-fix methodology. It calls for daring, indeed for being unsettled, for becoming fluid and flexible - to move. Perhaps timing could be called the 'art of improvisation. Timing in fact hinges on improvisation, and time cannot be separated from movement, as we noted earlier. ${ }^{16}$ Timing implies the ability to juggle more than one ball in the air, knowing when to catch, and when to release, to keep the 'circular movement' going. Timing, i.e. improvisation, could also be compared to the art of creating exceptional jazz music. In a provocative exposition of the possibility of a 'jazz theology', Reddie juggles as follows:

Just as the participant in the drama constantly re-engages and re-negotiates with the text, this is equally the case with the preacher and the jazz musician. The improvisation of the jazz musician is built around the process of engaging with the inherited melody and then having the confidence to go beyond that fixed nature of the text. The improvisation is the link between the fixity of the text and the openness of the context... The improvisation of the preacher exists in the interchange between fixity of the text (scripture) and the fluidity of the context (the congregation and the overall worship service). The best preachers are able to apply the text to the context and use the former to give new life and fresh insight to the latter. ${ }^{17}$

The fluidity (movement) between text (what) and context (whom), is given through timing (when). This does not mean that the jazz-preacher has no basis or methodology; on the contrary, as Charles Campbell reminds us: jazz connects knowledge and mastery of the fundamentals with the freedom of artistic expression. ${ }^{18}$ In the same sense, improvisation in preaching does not mean being unprepared. You can only improvise, if you master the art and knowledge of tone, harmony, and rhythm indicated on the musical scoresheet. You can only time, if you know the tune of the (biblical) text, so to speak.

The use of improvisation is, however, not the privilege of jazz musicians alone. Music as such - which has often been used as a paradigm for preaching - can, to a certain extent, not exist without improvisation. ${ }^{19}$ Even within musical score sheets, time-frames, pauses - timing, if you will - are part and parcel

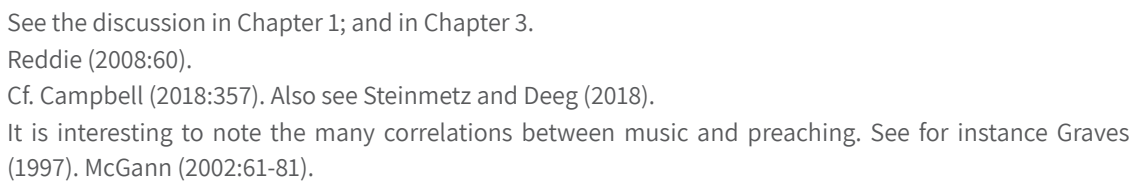


of the intended musical experience. Musical notes make no sense without empty spaces and times in-between. But, besides these 'built-in' intentions of timing, even seemingly 'set' music like those produced by the organ, make use of improvisation. ${ }^{20}$

Imogene Horsley for instance gives a wider definition of musical improvisation, which outlines the art of improvisation as a many-sided process:

(Improvisation is) the creation of a musical work, or the final form of a musical work, as it is being performed. It may involve the work's immediate composition by its performers, or the elaboration or adjustment of an existing framework, or anything in between. ${ }^{21}$

The two classical approaches to music, i.e. composition and improvisation, need not be separated in a strict manner. During improvisation, the musician creates and performs his or her music 'on the spot'. However, this does not mean that musicians that improvise can do whatever they want. Concerning the 'difference' between the musician that improvises and the musician that composes, we could say that the former creates and performs instantaneously and spontaneously and without long preparation, and mostly without any thought that it should be written down later. On the other hand, the 'similarity' between the improviser and the composer is that the improviser does in fact follow compositional rules. Improvisation is not about free and unstructured musical flights of fancy but is based on clearly defined concepts. ${ }^{22}$

Indeed, improvisation also makes use of composition: to compose - from the Latin: com-ponere - to bring or set together. With improvisation, the combining of the elements could be done in a seemingly random manner. Improvisation could also be described in terms of another Latin expression, namely generare - to create in the sense of develop. Here, the bringing together of the elements is largely according to certain musical rules and regulations. Both of these creative elements constitute the art of improvisation, and are, in fact, underlined by the notion of timing: to know when (and how) to make use of formalities, and when (and how) to create 'on the spot', and 'in the moment.'23

In this regard, the differences between so-called Western and African expressions of music is particularly interesting. African music has its own rhythms, indeed

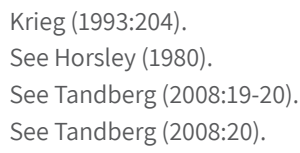


its own rhythms of life. Interestingly, Western traditions with their ocular and linear approaches are more orientated towards music as 'melody' (individual steps and parts harmoniously combined into a finished performance piece), whilst in African oral cultures it is rhythmical and even poly-rhythmical structures that create 'discontinuity' in the musical score. ${ }^{24}$

The intention of African rhythm is however not (as the word 'discontinuity' may suggest) to 'disrupt' the flow of the music; rather it means that the emphasis is not necessarily on 'melodious coherence', but on the 'impetus for life that rhythm can provide.' In African spirituality singing is all about bringing people back to the rhythms of life. Singing expresses and underscores the life-cycle - therefore Africans sing from the cradle to the grave. (In Africa, music condenses time; it brings those who sing back to their origins, but also gives meaning to the present as sacred time. $)^{25}$

The art of improvisation has been called a habitus of 'relaxed awareness', being part of the make-up of seasoned musicians. ${ }^{26}$ This form of awareness entails having an acute aural, visual, and kinaesthetic memory:

These kinds of memory provide the musician with the capacity to know where one is in a given musical moment and 'where the music needs to go'. The ear receives the current harmonic structure and instinctually anticipates where it is headed. The eye sees the music, or the mind's eye recalls it, and the mind anticipates which notes and expressions are to follow. The hands and body experience the articulation of a given moment and anticipate how next to move as a matter of habit. ${ }^{27}$

But not only musicians practice improvisation. In the world of sports, of dancing, of stand-up comedy, of creative arts like painting, etc., 'timing is everything. The importance of timing hinges on the fact that it enables one to not only identify and signify the contributing factors or role-players, but also to transform and transcend them, by means of discernment. In the end,

\footnotetext{
24 Katani (2008:115).

25 Eliade (1971:151-152). See also Cilliers (2014:36-48). "It is quite amazing that we have a word in Africa that signifies the transcendental feeling induced by music - a word that has no equivalent in the English language. It is the isiXhosa word Ihlombe, which expresses the ability of music to transport people to a state of overwhelming joy in which they become so acutely moved that they are compelled to stand up and participate - through dancing or otherwise. In the Zulu language Ihlombe translates into applause. This is truly the 'magic of musicking' - it faces reality to change reality, to applaud (a new) reality. The magic of musicking prompts applauding and dancing the novum." Cilliers (2014:43).

26 See Schmit (2008:184).

27 Schmit (2008:185).
} 
timing aims at creating 'a qualitative event that is more than the sum of the constituents that are connected through the event of timing.'28

It is interesting to note that some scholars in the field of ethics have also resorted to what could be called an 'ethics of improvisation', or 'the drama of improvised ethics' - in an effort to counteract the idea that ethics is, or should be, a rigid set of guidelines for life and behaviour. Samuel Wells, for instance, defines improvisation in the world of the theatre as 'a practice through which actors seek to develop trust in themselves and one another in order that they may conduct unscripted dramas without fear. ${ }^{29}$ According to this paradigm, this is what ethics should look like - the building of trust, without fear; experiencing relationships on which basis healthy and life-affirming choices can be made - all of which takes place without the smothering by a strict script. For Wells, the Bible does not represent a script like this, but rather a type of training school that shapes the habits and practices of the Christian community, inviting Christians into its times and spaces as 'apprentices' to the Bible. ${ }^{30}$

Someone like Tracey Nicholls uses the paradigm of improvised music to theorise about the characteristics of a politically just society. ${ }^{31}$ Some of these characteristics, taken from the cues given by the people who perform and listen to musical improvisation, would include respect for differences, or, as she calls it: aesthetic pluralism. ${ }^{32}$ In this sense, improvisation offers helpful insights into the ways that communities could or should operate, in particular when it concerns the healing of fractured and marginalised civil societies. ${ }^{33}$

It would indeed seem as if life - community - largely flourishes within 'spaces of improvisation', rather than enclaves of rigidity. It is my contention that preaching also flourish within these spaces. The Bible is not a textbook, filled with rigid laws, but with accounts of encounters resulting from, and resulting in, experiences of grace. ${ }^{34}$ Preaching articulates, and in so doing, co-creates, these experiences of grace.

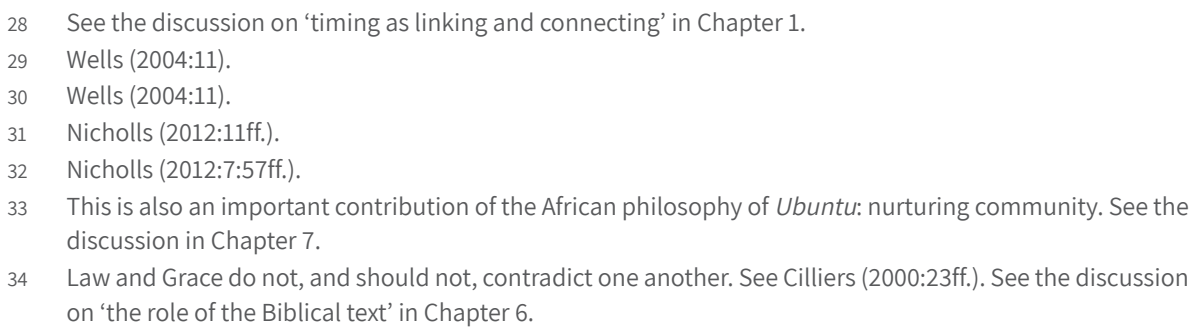

34 Law and Grace do not, and should not, contradict one another. See Cilliers (2000:23ff.). See the discussion on 'the role of the Biblical text' in Chapter 6. 


\section{Grace - what is this?}

The word 'grace', and variations thereof, probably represents one of the most used concepts in Christianity, perhaps even in all religions. But, what does 'grace' mean? In terms of this book, I would say that grace is the deconstruction of the 'predictable timing' of the conditional cause-and-effect structure, through the unconditional and mostly 'unpredictable improvisation' of time that is characteristic of timing. In this sense, grace is experienced in space and time, but also transcends the categories of space and time.

This is exemplified beautifully in the Old Testament narrative of the gift of manna, given to the Israelites in the desert. No one writes more poignantly about this than Louis-Marie Chauvet in his classic book, Symbol and Sacrament. It is worthwhile to quote him extensively in this regard:

Like the manna in the desert, which is perhaps its most beautiful expression, grace is of an entirely different order from that of value or empirical verifiability. Its very name is a question: Man hu? Its name is 'What is this?' Its consistency seems to be that of a 'something' which has all the traits of a 'nothing': something 'as fine as frost on the ground' which melts in the sun. Further, the measuring of it resembles a 'non-measure': they gather it up - 'some ... more, some less'; but when they proceed to estimate its quantity, they observe, contrary to all logic of value, that 'those who gathered much had nothing over, and those who had gathered less had no shortage'; finally, those who are, 'violating the Lord's command, wanted to store some for the future saw that it bred worms and became fowl'. (Exodus 16:9-21). Grace as a question, grace as a non-thing, grace as a non-value: How can we make sense of this pure sign which begins with a question, other than by choosing the path of 'symbol', the path of non-calculation and non-utility? ${ }^{35}$

Indeed, grace cannot be handled, and should not be manhandled. Grace fills up the moment called 'now', with enough for 'now'; fills up the 'here', with enough for 'here.' The question about what this is, is what graceful timing is about. Grace has its own unexpected and unconditional timing. None other than Martin Luther expressed this timing of grace in his inimitable way - also speaking of something incontrollable, coming from somewhere else, according

35 Chauvet (1995:44-45). 
to its own time, like manna. He reflected on his life, and had the following to say to his fellow citizens:

I think, that Germany has never before heard so much of God's Word as now. If we permit this to pass by without gratitude and honour, we are in danger of suffering even worse darkness and plague. Beloved Germans, buy while the market is close at hand! Gather while the sun is shining and while there is good weather! Make use of God's grace and Word while it is here! For you should know this: God's Word and grace is a passing downpour, which does not return to where it has already been. ${ }^{36}$

Grace is like a passing downpour, like rain. You cannot stop it, nor control it. It falls from the sky on everyone, sovereign, according to its own timing. Who can stop the drops? Who can chase the rain back to heaven ${ }^{37}$ This reminds one of what Thomas Merton once wrote about rain, albeit in another context. For him, it becomes a symbol of life, of the bounty and goodness of nature, of the safety and security of existing in a greater totality:

The rain that I am listening to now is different to that which falls in the cities. It fills the forests with a mighty and majestic sound. It covers the flat roof of the house and its veranda with its continuous and controlled rhythms. And I listen, because it reminds me time and again that the world functions according to rhythms that I have not yet learned to recognise, rhythms that are not those of human engineers ... No human initiated the rain, and no one is going to stop it. It will continue to speak on my roof as long as it pleases, this rain. And as long as it speaks, I will listen ... ${ }^{38}$

Such is grace. It cannot be controlled or created, rushed, or slowed down. And yet, when we preach, we hope for a downpour, we pray for an event-in-time, we long for a Kairos. It is fascinating to see the connections that African

36 Luther and Brandt continue: "It has been with the Jews; but what's lost is lost, and they now have nothing. Paul brought it to Greece; what's lost is lost, and they now have the Turks. Rome and Latin-speaking regions have also had it; what's lost is lost, and they now have the pope. And you Germans dare not think that you will have it forever, for the ingratitude and disdain will not let it remain. Therefore, take hold and hang on tightly, while you can to grab and to hold. Lazy hands are bound to have a hard year ... If I were to live another hundred years, and not only through the grace of God withstood the previous and present combinations of circumstances and storm winds, but let us say that I would also endure all future things, it still does not mean that this guarantees rest and peace for our descendants, because the devil lives and apparently reigns. Therefore, I also pray for an hour of grace, and desire nothing more. You, who are our descendants, pray earnestly and practice God's Word zealously. Maintain God's storm lantern, be warned and equipped, like people who expect that at any hour the devil will break open a window or pane, rip off a door or roof, to extinguish the light in the house". Quoted from Luther and Brandt (1962:352-353).

37 After all, God lets his rain fall on the righteous 'and' on the unrighteous (Matthew 5:45).

38 Paraphrased from Merton (1977:42). 
philosophers make between rain and grace. Mbiti, for instance, writes beautifully about this:

Rain has a deeply religious rhythm, and those who 'deal' in it, transact business of the highest religious calibre. Rain is the manifestation of the eternal, in the here and now.... not only solicit physical rain but symbolise man's (sic) contact with the blessings of time and eternity. ${ }^{39}$

Dare I say this? Preachers are also rainmakers, or we could say timers, or co-timers, of grace. Preachers look to the skies, reading the signs of the times, waiting for the moment to announce the connection between what is coming (or is already), and the parched earth, waiting in anticipation. In this sense, preachers synchronise realities, synchronise worlds that need to be connected; or better: that need to be reminded of their connectedness through grace. Preachers are synchronisers of manna and humanity; of rain and reality; of Kairos and (our) clocks; of Pleroma and (our) plight.

\section{Time for synchronization ...}

Indeed: the 'times we live in' are in dire need to be 'synchronised' to the time, and timing, of the gospel. The timing of grace in and through preaching is about 'improvisation', but it is also about 'synchronization'.

Jazz music understands the art of improvisation; 'post-minimalistic aesthetics' (as expressed in 'process art'), excels in synchronizing 'the times we live in'. In my opinion, both 'improvisation' and 'synchronization' offer rich, albeit often unsettling impulses for preaching. As an example of the latter, I refer to an artwork by Cuban-born artist Felix Gonzalez-Torres. ${ }^{40}$ The artwork had no title, Untitled, but later became known as Perfect Lovers. ${ }^{41}$ It simply consists of two identical, battery-operated clocks, synchronised and hanging side-by-side. These everyday objects carry the undertones of the now famous Duchampian notion of 'readymade objects', being brought into a space of art, and thus

\section{Mbiti (1990:177).}

40 Felix Gonzalez-Torres: American Conceptual, Post-Minimalist and Relational Aesthetics Artist; Movements and Styles: Post-Minimalism, Relational Aesthetics, Conceptual Art, and Postmodernism. Born on November 261957 - Guaimaro, Cuba; Died: January 9, 1996 - Miami, Florida.

41 It was displayed in the Dallas Museum of Art during 1987-1990. It is interesting to note that almost all Gonzalez-Torres's works had no title, except 'Untitled', often followed by a description between brackets. This seems to have been a deliberate strategy on part of the artist, to underline the fluidity and openness of this art installation. 
receiving new, and multiple, meanings. It also reminds one of the trends in minimalist sculpture to offer austere forms and serial repetition. ${ }^{42}$

It is quite moving to know that the artist created this installation while his life-partner, Ross Laycock, was dying from Aids. Gonzalez-Torres understood the fluidity of time, and the fleetingness of life - he knew that the two seemingly absolutely similar clocks would fall out of sync, one eventually stopping first. The artwork expresses his fear of, and for, time. ${ }^{43}$ It represents an aesthetic expression of the fear of losing a relationship, of the fear of losing time, losing synchronicity. Simply (aesthetically) put: this artwork is an effort to keep (the) times ticking on, together - if possible, forever. The artist states:

Time is something that scares me ... or used to. This piece I made with the two clocks was the scariest thing I have ever done. I wanted to face it. I wanted those two clocks right in front of me, ticking. ${ }^{44}$

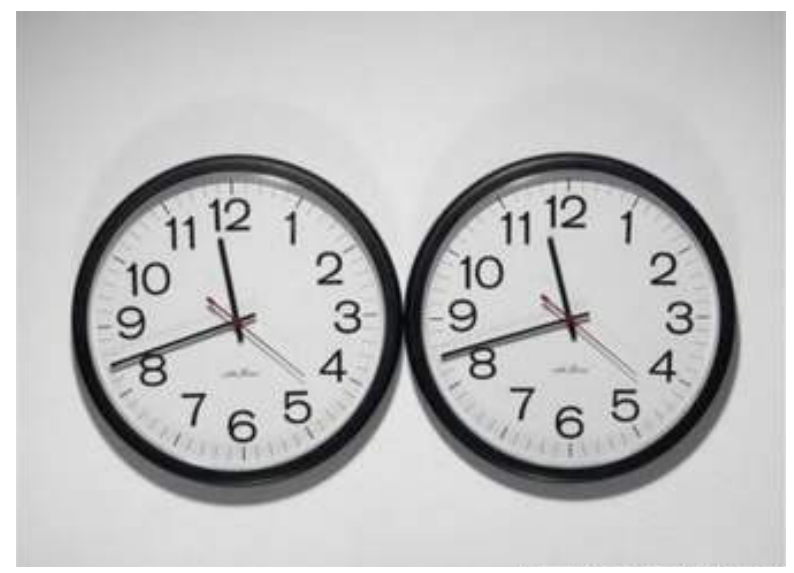

Figure 2.1 Felix Gonzalez-Torres's “Untitled” Perfect Lovers (1987-1990) can be seen in the Wadsworth Atheneum Museum of Art, Hartford, Connecticut (Brooks, 2014)

\footnotetext{
42 "Minimalist painting and drawing are monochromatic and often draws on mathematically derived grids and linear matrices; yet it can also evoke a sensation of the sublime and of states of being ... This sculpture has no illusionistic properties, relying instead on a bodily experience of the work by the spectator." See Butler, Van Cleave and Stirling (1996:509).

43 If one looks closely at the shadows of the clock's hands, you will see that they are already slightly out of sync ... their shadows differ.

44 Nickas (2016).
} 
Gonzalez-Torres was quite explicit in his guidelines given to the museum, concerning the way in which his installation should be set-up and maintained. These detailed instructions became an intrinsic part of the artwork itself:

When installed, the two clocks were to touch; the clocks could be replaced with white plastic commercial clocks of similar dimensions and design; the minute and second hands were to be set in sync, with the understanding that eventually they might go out of sync during the course of the exhibition; if one of the clocks needed the batteries replaced, it was to be done, and the clocks were to be reset accordingly; the clocks were to be displayed on a wall painted light blue. ${ }^{45}$

Taking my cue from this artwork, I would postulate that preaching is, inter alia, about the synchronisation of the times, i.e. of the 'times we live in', and the time of the gospel, as inaugurated by the Christ-event. Ideally speaking, these two times should be in sync (like in a love-relationship), but we know that this is often not the case. The times of grace and everyday life (with its readymade objects!) should be ticking in harmony; should share the same timeslot; should resonate ... but it does not, sadly enough. Therefore, these times need to be synchronised, need to be brought into synchronicity. This is the role of preaching - tuning everyday-time into God's-time, coming into sync with the Kairos of the Christ-event - and vice versa.

We live in a world characterised by crises, and fear - the latter becoming a type of global phenomenon. Our fear can, and does, take on different forms and intensities. 'A time like this' is indeed a fear-filled time. Our greatest fear - in particular as preachers - should after all be that we fall out of sync with God's time; that we miss out on the Christ-Kairos; that we follow the ticking of our own clocks; that we lack discernment (phronēsis). In this sense timing, or rather mistiming is indeed, in the words of Gonzalez-Torres 'the scariest thing' we could ever do.

The times we live in are crises-times; they are also Kairos-times, i.e. they are times that could be interpreted against the background of the fulfilment of time in and through the Christ-event. ${ }^{46}$ They are fear-filled times, but they are also - and simultaneously - times for fearing (honouring, worshipping,

Brooks (2014)

See comments on 'The Fulfilment of Time' further on in Chapter 7. 
expecting the advent of) God ${ }^{47}$ After all, God's time-clock is not far away; as a matter of fact - it touches our times; it is ticking close by ... ${ }^{48}$

Preaching serves, and uncovers this touching of the times, this salvific simultaneousness, this (possibility of) synchronicity. But, the notion of synchronicity should not be romanticised. It is not, in the first instance, about creating an 'eternal' equilibrium of 'fairyland' times; rather indicates the reality that the times that we live in, 'times such as these' need to be (continuously) brought into sync, one could say: be interrupted, by grace. ${ }^{49}$ Synchronisation implies interruption; aims at transformation of times - in accordance with the fullness (Pleroma) of Kairos-time..$^{50}$ This can be a highly unsettling event, even though, or rather: exactly because, it is filled with grace.

Preaching serves the 'synchronization of this unsettling, interruptive grace', in the dual sense of the expression: it is grace that synchronises the event of preaching, and grace is being synchronised through the event of preaching. In terms of the latter, preachers are never masters, or manipulators, of this grace. Grace happens, and preachers that sense this graceful happening, cannot do much more than to point towards the close-by ticking clock of Kairos, and pray for open ears and enlightened eyes.

As we said earlier, this 'sensing of the graceful happening' calls for 'improvisation', i.e. to be open to the promptings, movements, downpours, and manna-manifestations of the Kairos-event, and to respond to it. But it also calls for 'synchronisation'. Synchronisation is needed to find the connection between the score sheet (the gospel-time of interruptive grace), and the 'situation' (the times we live in). ${ }^{51}$ In order to find this connection, we need the art of improvisation.

47 An interesting classical-literary counterpart (or perhaps opposite) of this 'simultaneity of times' could be the famous words by Dickens: "It was the best of times, it was the worst of times, it was the age of wisdom, it was the age of foolishness, it was the epoch of belief, it was the epoch of incredulity, it was the season of Light, it was the season of Darkness, it was the spring of hope, it was the winter of despair, we had everything before us, we had nothing before us, we were all going direct to Heaven, we were all going direct the other way - in short, the period was so far like the present period, that some of its noisiest authorities insisted on its being received, for good or for evil, in the superlative degree of comparison only." Dickens (1859).

48 Cf. Paul's conviction in 2 Corinthians 6:2: "I tell you, now is the time of God's favour; and now is the day of salvation."

49 On the notion of interruption, see Campbell and Cilliers (2012:35ff.). See the discussion further on in Chapter 4 about 'Interrupting Time'.

50 See Cilliers (2016a:35ff.).

51 See the discussion about 'situation' in Chapter 3 and 6. 


\section{SERMON: TRUTH OR FICTION?}

This is what the Lord Almighty, the God of Israel, says ...

JEREMIAH 28:2,14

A church and a theatre stood next to each other. The minister of the church decided to present a series of revival services for an entire week. This was advertised everywhere, in all the congregations in the city, with posters, brochures and announcements. The first evening there was quite a crowd, but the next night only a few, and on the last night, only three.

In the meantime, an unknown actor decided to present a one-man-show in the theatre - coincidentally in the same week as the revival services in the church next door. It was announced with a single poster in front of the theatre and a short report in the local paper. The first night three people pitched up. The next night the theatre was full. By the end of the week, they had to turn people away at the doors.

The day after the last performance, and the last revival service, the minister walked over to the actor and at his wits end asked:

How do you do it? What is the secret of your success? You proclaim fiction, and look at the crowds; I proclaim the truth, and look at the slender turn out?

The actor answered briefly and to the point: "The difference is I proclaim fiction as if it is the truth, but you proclaim the truth as if it is fiction.

The minister went home without saying a word.

What is truth? What is fiction? What - and whom - should we believe? These kinds of questions pile up in Jeremiah 28. Interpreters draw attention to the rising line of tension in the book Jeremiah, an increasing confrontation between the true and false prophets, which reaches breaking point in Jeremiah 28. Let us venture into this field of tension. 
With the first words we become part of the crowd in the temple court, we become witnesses as two formidable prophets face off - Hananiah, son of Azzur from Gibeon, and Jeremiah, son of Hilkiah from Anathoth. Sparks fly.

Hananiah goes first. He proclaims the best of messages, a message of hope:

This is what the Lord Almighty, the God of Israel, says: 'I will break the yoke of the king of Babylon. Within two years, I will bring back to this place all the articles of the Lord's house that Nebuchadnezzar king of Babylon removed from here and took to Babylon. I will also bring back to this place Jehoiachin, son of Jehoiakim, king of Judah and all the other exiles from Judah who went to Babylon,' declares the Lord. ${ }^{52}$

A tingle of excitement runs through the crowd. They know this message; they have heard it before. After all, it is a message founded on a strong prophetical tradition, the so-called Zionist tradition, according to which the Lord the Almighty, the God of Israel, takes responsibility for assembling God's people in Zion. Many prophets have proclaimed this. Barely a century before a great figure like Isaiah said the same. And now Hananiah, like the prophets before him, confirms the Lord's merciful dealings with these people - it is not in vain that the name Hananiah means: The Lord is merciful!

Masterfully, with rhetorical and dramatic finesse, Hananiah brings his sermon to a climax ...

His performance is so impressive that Jeremiah cannot really oppose it. The first word in his response in the Hebrew text is: 'Amen.53 Let it be! And he is not being ironical. Then, as if reconsidering, Jeremiah makes his first point: "Hananiah, you and the entire nation know that there is also another prophetic tradition that says that true prophets foretell mostly wars and disasters and pests, not prosperity like you. Prophets who proclaim prosperity, are only true prophets if their words are proven true, but you, Hananiah ...."54

At this point Hananiah interrupts him, takes the wooden yoke that Jeremiah wore as symbol, and breaks it before everyone's eyes. A murmur, then shouts of delight run throughout the crowd. Surely, this is such a sensational sermon that the congregation would be discussing it for years to come! It is as if this dramatic

\footnotetext{
Cf. Jeremiah 28:2-4.

Jeremiah 28:6.

Cf. Jeremiah 28:6-9.
} 
and highly entertaining pulpit performance takes the wind out of Jeremiah's sails. Somewhat sheepishly, he walks away for a short prophetic recess ...

But he returns shortly ... with the second point in his sermon: "Hananiah, you break wooden yokes, but instead you and the people will wear iron yokes. The judgement on you will not subside but will become greater". ${ }^{55}$

Feeling the tension, Jeremiah does not waste words. Briefly and powerfully, he fires point number 3: "Hananiah, you will be the first casualty. By the end of this year you will be dead ..." ${ }^{m 6}$

You can hear a pin drop in the temple court. Whom should the people believe? Who is speaking the truth? This is prophet versus prophet, Man of God versus Man of God. "This is what the Lord Almighty, the God of Israel, says," says the one. "This is what the Lord Almighty, the God of Israel, says," says the other. ${ }^{57}$ It is six of one and half a dozen of the other. Which God is speaking to which prophet? Will the real Prophet please stand up? Or is God defying God here?

This is not an easy question to answer. Anyone who has been called to proclaim the Word of God sometimes wrestles with this question: Am I preaching my message or the Lord's message? By nature, we tend to block our ears to the Word of God. We adapt, minimise, and trivialise God's Word. We domesticate what we deem dangerous in God's Word ...

So, which norm can we use to distinguish God's Word as 'God's' Word? I would like to list three options, which do not defuse this tension, but rather increase it.

» One could say that the difference between true and false prophets only becomes clear with the course of time. The course of history would show that Hananiah was the false and Jeremiah the true prophet - which in fact happened. Therefore, the final editors of the book Jeremiah could place these two prophets in categories, with the later added on heading of the chapter, 'The false prophet Hananiah', underlining their choice.

Still, this is of little use to those of us standing in the temple court right now, listening to the two prophets. Do you have to wait 20 or 100 years before you know from whose mouth the Lord is speaking? Must we be satisfied with a mere echo of God's Word after a few centuries? No Word of God, 'now'?

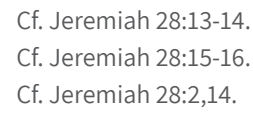


One could also search for the distinction between the two prophets in the difference in dogmatic content. Hananiah proclaims a quick fix: 'Grab the sword, break the yoke of Babylon yourselves!' Jeremiah preaches a slow, painful solution: 'Submit yourselves to the judgement of the Lord on us, and the Lord will bring about a future for us.' Hence: self-justification as opposed to Godly justification, own interest opposed to God's mercy. This is a juxtaposition that keeps surfacing in church history: Paul versus the heretics in Galatians, Pelagius versus Augustine, Rome versus the Reformation, to name but a few. This may be true. But then the question is: What about the prophets in the Zionist tradition before Hananiah? Were they all wrong? Should they all be dismissed as heretics?

Let us try again. The distinction between the two prophets can be found in their timing. Hananiah reads the timing incorrectly. He misjudges the hour. The content of his message is correct, but the timing is wrong. He cries: 'Peace! Peace!', while God's hour for peace has not arrived yet. He proclaims timeless truths, but at the wrong time, and therefore false. He preaches yesterday's theology, which was a good theology for 'yesterday', but from his mouth, it degenerates into today's ideology. What is true, becomes fiction.

I sympathise with Hananiah. Let us be honest: by nature, we would rather not have God in this hour, we would prefer to dodge a face-to-face meeting with God in this 'now'. Oh, we are happy with the 'formal' and 'correctsounding' Word of God, if it is an empty shell. (We use our theology to 'talk God to death'. And I don't say that lightly.)

One of the characters in the South African author Chris Barnard's provocative book, entitled Moerland, makes this bloodcurdling comment: "Afrikaans ministers speak in such a way that eventually one cannot hear a word God is saying." Perhaps this is true. What a disturbing, interruptive question: Is the Afrikaans-speaking church - and all others - up to date, prophetically? Are we 'synchronised' with God's voice? Am I?

You can sense it. The tension does not want to abandon the text but does not want to abandon us either. Perhaps it should not. Perhaps the best thing that can happen to us, is for the Word to make us tense again. At least this might make us 'pray', 'call out' for the Word of God; not just for the letters on paper, but for the 'living God of the Word'.

This living God of the Word comes timely, fulfilling time.

This timing is everything. 


\section{Chapter 3}

Mistiming Grace

\section{"The gospel as law for the hour ..."?}

I reiterate, grace has its own time, and calls for timing. Preachers are called to be co-timers of grace. But, as we know well enough, the time and timing of grace can be overlooked or ignored. Grace can be missed or dismissed; can be mistimed. Nowhere is this seen more vividly, than in certain forms of preaching during the 'time of apartheid'.

The time of apartheid could be described in many ways. It could, without a doubt, be called a time of socio-political turmoil in South Africa as seldom experienced before. Apartheid was, on the one hand, characterised by post-war prosperity among a large part of the white population (1960 to 1980), and, on the other hand, by a growing relational problem and alienation among the various population groups. In this respect, the events at Sharpeville (1960) formed a type of watershed, and focused the world's attention on South Africa, with increasing foreign isolation, sanctions, and internal unrest and violence. South Africa's subsequent withdrawal from the Commonwealth (May 1961) caused its greatest economic crisis since the depression of 1930 to 1932. A combination of political, economic and social factors escalated into another watershed moment for South Africa, with the youth taking to the streets in the Soweto-uprising of 1976, resulting in a governmental clamp-down, called the 'state of emergency' - the latter perhaps being one of the darkest phases of the apartheid era. During this state of emergency, there were numerous violations of human rights, perpetuation of economic and social injustices, illegal detentions, etc.

All this eventually led to the release of Nelson Mandela, resulting in the first democratic general elections on 27 April 1994, which were described by many as 'nothing short of a miracle'. 
The details of this period in our South African history need not be repeated here; ${ }^{1}$ suffice to say that in the run-up to the first democratic elections the country was balanced on a knife-edge, with a full-scale civil war and unimaginable bloodshed a real possibility. If ever there was a time for timing, i.e. for preaching the 'interruptive grace of the gospel', it was then. We are reminded of Bonhoeffer who declared that although life should not be overburdened with the ethical in a pathological manner, there may come times when this very life is threatened to such an extent that the church, if it wishes to retain its integrity, has no other alternative but to proclaim the 'gospel as law for the hour.'2

The link between ethics and improvisation, referred to earlier, comes into play again here: improvisation offers helpful insights into the (ethical) ways that communities could or should operate, in particular when it concerns the healing of fractured and marginalised civil societies. ${ }^{3}$ This was clearly such a time for ethical improvisation, such a Kairos, in South African history. ${ }^{4}$

\section{Sillence...}

But, sadly enough, it became clear, albeit in retrospection, that a large part of the official preaching (being done on the radio and television), missed out on the opportunity to speak out and proclaim the gospel as law for the hour. The hour of grace was mistimed. The first perspective - or observation - in this regard is simply that a large part of the church was silent during the time of apartheid. Silence is a distinct form of (un)ethical preaching. It either expresses fear for the status quo, or acceptance thereof. It stabilises and legitimises the powers that be. It presupposes a certain ethical stance, which says: the status quo is good, or at least bearable. This form of fixated and stabilising (un)ethical preaching stands in contrast to the ethics of improvisation. ${ }^{5}$

The syndrome of silence was not new, at least within certain sectors of the South African context. Research done on trends in Afrikaans religious programmes as far back as 1987 indicates that the religion that was offered to ordinary Afrikaans-speaking people then was almost always 'imperative' in nature, but not as an appeal that affects the daily and concrete reality. It

\footnotetext{
For an extensive discussion, cf. Müller (1980:510-520). For an overview of the democratic transition, cf. Giliomee and Mbenga (2007:330ff.).

Bonhoeffer (1955:66ff.).

See the discussion in Chapter 2.

Many South Africans would say that we are in fact experiencing another such a 'Kairos' at present.

See the discussion in Chapter 2.
} 
rather was a type of alien-to-daily-life, non-existential appeal on the grounds of pietistic potential. The programmes' 'contents' said virtually nothing about the issues that, for instance, received attention in the daily press. This research, conducted in conjunction with the Department of Journalism at Stellenbosch University, found that not one of the ten most commented on issues of the day was reflected in the sermons that were broadcast. ${ }^{6}$ Socio-political issues like the following, received no, or very little attention in a total of 165 sermons and meditations preached on television and radio between April and November 1987:

»Violence, including murder and crime: 0,06\%

» Human Rights: 0,03\%

»Detention and political trials: $0 \%$

» Freedom of press: 0\%

» Military violence, Governmental acts: 0\%

» The right to protest, protest actions: $0 \%$

» Group Areas Act 0\%

»Discrimination, e.g. in education, health services, wages, etc.: $0 \%$

» Poverty, hunger, housing: 1,38\%

» Joblessness: 0,03\%

»Sexuality: $1 \%$

» Drugs, alcoholism: 0,06\%

»Ecological issues: 0\%

This is truly remarkable; even more so, $\operatorname{sad}{ }^{8}$ Nothing to be said over the Group Areas Act in 1987, and the forceful removal of millions of people? Not a single word about discrimination? Almost no sermons on poverty and hunger?

Unthinkable ... but true.

But it does not end there. During 1994, the year during which the first democratic elections took place in South Africa, the Human Sciences Research Council (HSRC), working with a group of content analysts at the Faculty of Theology, Stellenbosch University, posed the following questions: how did preachers respond to the dawn of the 'new South Africa', with its concomitant promises

Boesak's words ring true: “... the silence that some want the church to maintain on these issues means that they are affirming the status quo." Boesak (1979:11). 
of 'justice for all'? (If they were silent about injustice in the past, how would they speak about justice in the present?) Could any change in fact be detected in preaching in South Africa during this transition from socially structured injustice to socially structured justice?

This project, again done as interdisciplinary research, conducted in conjunction with the Departments of Sociology and Journalism at Stellenbosch University, was entitled, Preaching in contexts of change. An investigation into preaching on Radio South Africa, Afrikaans Stereo and Radio Pulpit before and after the general elections of 1994. ${ }^{9}$ The selection of sermons was made from worship services being broadcast on the two Sundays before the election (27 April 1994) on Afrikaans Stereo, Radio South Africa and Radio Pulpit. This was followed by analyses of sermons broadcast one month and again three months after the election. In terms of content, the researchers were especially interested in how preachers 'thought and indeed spoke literally about the situation of change'.

The project did not claim that the selection was representative of all sermons during this time, merely that noteworthy trends could be identified. These trends were described by the following literal pronouncements of preachers as closely as possible. One of the findings disclosed the reality that there was:

\section{Silence ... again.}

There were a surprising number of sermons that completely circumvented the circumstances at the time - much like the sermons of 1987. In these sermons, references were only made to general human problems like the pressure of competitiveness, tensions between parents and children, etc. ${ }^{10}$ Biblical directives were given for various life problems, specific to the more affluent part of society, those who own swimming pools, sports cars and entertainment (barbeque) rooms (Afrikaans: braaikamers). Apparently, the sermons were directed at people who were living spiritually isolated from what was happening in the country - a life without problems like unemployment, poverty, etc.

The imperative in these kinds of sermons seemed to be entirely in terms of the 'spiritual' and personal aspects of life, admonishing people to come to a new spiritual approach. Such a changed spiritual approach could of course have had implications for the situation in the country - but the sermons did not address these implications in any way. It seems that the situation in the country

Human Sciences Research Council (1994).

Obviously, there were also sermons that spoke against South African realities, ranging from expressions of fear, to uncertainty, to euphoria. For a detailed discussion, see Cilliers (2016:21-33). 
then was not really seen as a problem and not as an emergency - the problems in life are viewed on a spiritual level for which the sermons offered Christ as the patent solution. Not a single word was uttered on issues like social and economic justice, and not a single confession of guilt in view of the past was heard.

'Now' was filled up with irrelevant, so-called 'spiritual' jargon, but as far as the law of the hour, the Kairos was concerned, the present was side-stepped with silence.

Deafening silence ...

\section{"In times like these ..."?}

Obviously, some sermons were not silent about South African realities, but the reality is that many of these spoke out 'in favour of' apartheid.

During 1994, I did research on South African preaching during the period 1960-1980, and analysed a number of sermons in detail, in conjunction with the Ökumenischer Vereins zur Förderung der Predigt, situated in Heidelberg, Germany. ${ }^{11}$ Representative sermons were selected (118), with specific attention given to a further selection (14), in view of a detailed 'close-reading' analysis, making use of certain linguistic and theological criteria. (It was quite remarkable to discover that the basic hermeneutical structure, underpinning the God-images used in these sermons, were largely, the same.)

It was furthermore interesting to note that this basic structure could also be seen in many of German sermons, in particular those that were preached during, and directly after the Second World War - sermons wrestling with issues of guilt, justice, and reconciliation. What follows, is a highly abbreviated version of the most important aspects of this stereotypical hermeneutical structure, a structure that was crude, but seemingly effective. ${ }^{12}$

It consisted of three steps: First, the status quo was legitimised by means of biblical analogies (e.g. 'As it was with Israel, so it is with South Africa'). This schematic analogy was used as a primary and primitive homiletic tool to 'stabilise' the Afrikaner nation ('volk') in times of anxiety and turmoil, implying

11 First published in Afrikaans as Cilliers (1994). Later published in English as Cilliers (2006). As stated above, 1960 to 1980 was an important phase of the apartheid-era, starting with the events at Sharpeville in 1960.

12 Cf. my detailed analyses of this stereotypical hermeneutical structure, in Cilliers (2006:14ff.). 
that as God was for Israel, so God is for the 'volk.'13 (The use of this analogous scheme represented a search for 'security' in a time of emergency.) In the process God became the personification of an idea, a mechanism by which national viewpoints were projected on a metaphysical level. (God became 'nationalised.)

This movement backwards, into the security of historical analogies, was, in my opinion, a striking example of mistiming, i.e. homiletical escapism. (It represented a way of 'escaping from time', from the 'continuation of time', and from 'God's self-revelation in time'); it was a reach back into history to avoid contemporary realities and the challenges of the future. It represented a form of 'anti-prophecy' that does not dare to jump ahead, but rather arrests time and reproduces history. A selection of certain God-images took place - speaking often about the 'Almighty', or the 'One that determines the destiny of nations', etc., but less about God-images that would threaten or interrupt the status quo. Preaching during the era of apartheid could indeed be described as an expression of an 'iron theology' ${ }^{\prime 14}$, that encapsulated God in dogmatic certainties and ecclesial confessions. In a sense, God did not/could not 'move'. (God had to act in accordance with the selected analogies: 'as in the past, so today')

Secondly, the audience were admonished to guard zealously over their own 'morality', to move inwards, into their 'potential' as religious people. All the sermons included a type of 'national programme' which consisted basically of moralising appeals. The 'volk' had to be strong and healthy. In this way God would ensure its future. The (Afrikaner) people were called upon to dig deep into themselves, to become introspective, to find the answers to the crises in the recesses of their inner potential.

In sermons like these, theological articulations became moralistic appeals; given situations (in which God acts) became conditional situations (in which people must act); for example: 'If we as Afrikaners can act again like the people of Israel, God will bless us exactly as God blessed Israel'; 'If we as Afrikaners have faith like Abraham, God will lead us to our destiny, just as God led Abraham, etc. ${ }^{15}$ Like I said, crude, but effective. At least linguistically speaking, 'God' was taken out of the picture, or at least put on hold. In a sense, again, God could not 'move', at least not before people made their pious moves.

\footnotetext{
The Afrikaans word 'volk' constitutes a key concept in these sermons. 'Volk' could be translated as people or nation, but explicitly meant the white Afrikaner as an ethnic group.

Cf. Campbell and Cilliers (2012:63ff.).

Cf. Cilliers (2006:19).
} 
Thirdly, the 'outsiders' were turned into enemies and in fact demonised. Now the hermeneutical movement was outwards, projecting guilt onto the 'enemy'. One of the ways in which the security (identity) of the people was stabilised in these sermons was by projecting guilt onto 'others'. A dualism was formed between the 'inner group' (the nation) and the 'external group' (the enemies).

The primary function of this projection of guilt was self-justification, in the sense that a negative delimitation of the others confirmed the nation's own identity - a type of justificatio populi. To the extent that the others were stigmatised as enemies of God, the nation was stabilised as friends of God; the polemic against the others strengthened the apology for one's own nation. Here, we truly see the homiletics of apartheid at work: 'we', the Afrikaners, are here (a minority against the world, but righteous in our actions); and 'they', the enemy, are there (a majority and intrinsically evil). 'We' must be kept apart and intact as a people at all costs.

We could say that sermons like these reverted and perverted the dynamic sense of 'movement' inherent in certain God-images; in effect turning it upside down. In a temporal sense, the clock was perpetually turned backwards, in search of historical anchors to stabilise the 'volk' in the present; the novum of God's surprising and often disturbing future continuously breaking into the presence was not entered to. The 'event' of sermons like these (many of them being rhetorically very powerful) intended, or at least resulted in a certain paradoxical 'experience': it addressed the fear of the audience, but also fuelled it. And furthermore: on the grounds of this double-edged fear it called for action, but not to change the status quo, rather to move deeper into the moralistic and exclusive world of the enclave. ${ }^{16}$

Sermons like these often took on apocalyptic tones, in a negative sense: the 'own' and the known are being endangered, and these forces of endangerment should be resisted at all costs - because, if the own and the known are destroyed, the world would come to an end. The basic experience that these sermonic voices called for, and created, was that of fear. (Fear became the fundamental, heuristic experience that provided these sermons with structure and gave them content. ${ }^{17}$ Fear lead to a freezing of God-images. God could not, should not 'move', out of fear for change.) 
As a striking example of this heuristic experience of fear, I refer to a sermon preached during the height of apartheid and published in 1973 in the official journal of the Dutch Reformed Church in South Africa, Die Kerkbode. This sermon combines all three hermeneutical movements described above, the third (projection of guilt on an 'enemy', who is to be feared). It takes its slogan from Esther 4:14, which ironically enough speaks about 'a time such as this', i.e. it endeavours to bring the 'timing' of events in the Book of Esther into correlation with the 'times' in which the (predominantly white) Dutch Reformed Church (DRC) members found themselves in 1973. ${ }^{18}$ These (latter) times are described in terms of fear - fear as a result of envisaged threats that endangered the existence and 'values' of the members of the DRC. In a sense, it is a fear-filled sermon; a sermon in fear of fear.

The point of departure is that there is a similarity (or analogy; the first hermeneutical step) between the time of Esther and 'a time such as this.' The preacher declares:

Those who can discern the signs of the times correctly, will agree that we, the Afrikaner nation and Christendom in Southern Africa experience times of crisis as never before. About this, experts of our time agree ...

Our greatest danger is not the Communist force of arms or the military power of some or other country; our greatest threat is not a struggle against flesh and blood, but against the subtle power of the dark, that is unobtrusively and slowly but surely breaking down our nation and our Christian believers' spiritual standards, our sense of moral and spiritual values. Modern Hamans threaten our future existence. All around us we again hear the cry of the French Revolution: equality, liberation and brotherhood and a misplaced emphasis is placed on unity - often to the detriment of the natural differences between races, nations and churches, as willed by God; and a false ecumenicity is striven towards, to the detriment of pluriformity or variety. All over, we also observe the signs of a so-called dialogue between Protestantism and Roman-Catholicism - the truth and the lie. The slogan of the day is: away with differences - one church, one world, and one nation! And behind this slogan we see the Sovereign of the Dark who is preparing the world's scene for the appearance of the Antichrist. May God open our eyes before it is for ever too late. We are in a crisis! 
Not only do we hear about the stereotypical 'threats' from outside and 'around us' - called 'times of crisis as never before' - but 'our nation and our Christian believers' have spiritual 'standards' and a 'sense of moral and spiritual values' as an assumed ability, and 'we' are also able to 'notice' and 'observe' that the actual enemy of the 'nation' is the 'subtle power of the dark', the 'Sovereign of the Dark' The nation (Afrikaners) is elevated to a level of morality and spirituality, which in fact contradicts reality. In addition, all of this takes place against an apocalyptic background in which the 'Antichrist' is coming.

'In times like these', the 'Antichrist and the Afrikaner are locked in spiritual battle.' The enemy is demonised; the Afrikaner sacralised. In fact, the 'Afrikaner nation and Christendom in Southern Africa' are seamlessly identified as a unity. But more than this: in an almost Manichaean-dualistic way, not only the world, but also God's relation to the world is divided into two: God is for 'us', and God is against the 'others'. In this sense, the analysis of 'times like these' serves that which does not exist (i.e. is unreal); it grades the nation as superhuman, innocent people and it degrades the others as inhuman, demonic people. As a dichotomy of passive and active, of God's friends versus God's enemies, this depends on the fictitious alternative and hypothesis that the others are in the sphere of Evil, and the nation is in the sphere of the Virtuous. 'We' are an offering because of 'our' Christianity and devotion, and the 'enemy' threatens because of its unchristian stance and Godlessness, because of its subservience to the 'lie' and the 'darkness'.

This conviction is ascribed to 'Those who can discern the signs of the times correctly' and backed up by a statement that uncritically asserts: 'About this, experts of our time agree ...' One could indeed ask: what experts? Obviously, those that agree with the arguments of the preacher and the ideology of the 'nation'. This seems to be a quite common, if not crude tool used in sermons like these: calling on abstract deductions like 'experts of our times', in an exclusive and authoritative sounding manner. All of this is punctuated by the outcry that sounds like a siren throughout the sermon: 'We are in a crisis!'

Perhaps this is a typical human reaction in (perceived) 'times of crisis'. As a psychological phenomenon, fear, without doubt, plays a decisive role in sermons like these. ${ }^{19}$ In a certain sense, it can indeed be regarded as the 'heuristic principle', as mentioned above - as the factor that opens the mouths of

19 Here, I do not endorse the distinction that says that anxiety is without object, and that fear focuses on a specific object - as classically proposed by Kierkegaard (1844). In practice, it would seem as if this distinction is often forced. 
preachers and forces the addressees (in this case: the nation) to listen with new attention. This determines the sermons' foundational structure in the sense that everything possible is done to counteract fear. The one pole in the sermons consists of a detailed description of the threat; the other the 'solutions' that are presented. (All of this takes place within the space of 'fear-filled tension'.)

One of the characteristics of fear is that it can cause a variety of reactions. For example, in situations of fear, 'defensive reactions' can be built up, aimed to protect one's own existence. This can stretch from primitive reactions to nuanced mechanisms. A common phenomenon is that fear about guilt, or better: the fear about the consequences of our own guilt is replaced by fear about the impact of something external and threatening. ('Fear of guilt' becomes, or is hidden behind, 'fear of fate.) One of the most common mechanisms to counteract guilt in fact relies on the creation of 'scapegoats', or the (often seemingly utterly believable) construction of 'conspiracy theories', or both. (This is indeed the 'unholy trinity' of fear-filled preaching: 'postulating yourself as an innocent victim'; creating a [demonised] scapegoat; and constructing a conspiracy theory ...)

The notion of ' a time like this' could also be understood as an effort to connect to a 'situation', within which the listeners find themselves. A 'situation' always takes place within a certain space, and a distinct time; a 'situation' is a condensation of space and time. Situational preaching calls, inter alia, for timing.

Few homileticians wrote more convincingly on the need for situational preaching, than the German practical theologian Ernst Lange. According to $\mathrm{him}$, the homiletical act is all about the effort to understand the listeners in their present situation ('gegenwärtige Situation'). ${ }^{20}$ This specific, present situation calls for an act of preaching that corresponds to this situation - preaching, according to Lange, in fact entails above else, the clarifying of the homiletical situation ('die Klärung der homiletischen Situation') ${ }^{21}$ Preaching is therefore not simply to repeat the ancient Biblical text, but to speak a daring, new word, that is necessary to be heard, here and now. ${ }^{22}$

In one of his most quoted sayings, he stresses this conviction that preaching entails talking to the listener about his and her life. It includes talking with him or her about their experiences and perceptions, their hopes and disappointments,

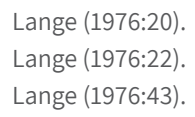


their successes and their losses, their tasks and their fates. It means talking to them about their worlds and their responsibilities in these worlds; about the threats and the possibilities of their existence. He, and she, the hearer, is the theme of preaching, nothing else - the hearer before God. Preaching talks to them about their lives in the light of the Christ-promise, as it is witnessed to in Holy Scripture. ${ }^{23}$

But we could ask, is this not precisely what the preacher quoted above, was trying to do - speaking relevantly in, and for, the 'situation' of his hearers? Was he not trying to be - in his own words - one of 'Those who can discern the signs of the times correctly'? Was he not trying to talk to his listeners about 'their worlds and their responsibilities in these worlds; about the threats and the possibilities of their existence'? One might even go further, and ask: if we were faced with such (perceived) threats and fear as those facing the preacher -'would we not have preached in the same way?' Perhaps we should not answer too quickly, and too glibly ...

At first glance, it would indeed seem as if this is a preacher who responds on behalf of his listeners to a situation experienced by them as fear-filled, trying to find an anchor. Perhaps he was thinking along the lines of the song that was popular amongst Christian youth movements during the seventies in South Africa, as follows:

In times like these you need a Saviour,

In times like these you need an anchor;

Be very sure, be very sure

Your anchor holds and grips the Solid rock!

It is indeed possible, perhaps even undoubtable, that the preacher honestly wants to anchor his listeners in a pastoral manner. However, taking Ernst Lange's understanding of situational preaching into account, one could also say that this preacher stressed the 'notion of responsibility' to such an extent, that it deteriorates into a type of religious activism - traditionally called moralism. ${ }^{24}$ The homiletical (theological) categories that Lange refers to, namely the hearer before God (coram deo), and the hearer in the light of the Christ-promise,

23 "Predigen heißt: ich rede mit dem Hörer über sein Leben. Ich rede mit ihm über seine Erfahrungen und Anschauungen, seine Hoffnungen und Enttäuschungen, seine Erfolge und sein Versagen, seine Aufgaben und sein Schicksal. Ich rede mit ihm über seine Welt und seine Verantwortung in dieser Welt, über die Bedrohungen und die Chanchen seines Daseins, er, der Hörer, ist mein Thema, nichts anderes; freilich: er, der Hörer vor Gott ... Ich rede mit ihm über sein Leben im Lichte der Christusverheißung, wie sie in der Heiligen Schrift bezeugt ist." Lange (1976:58,62).

24 See my comments in Cilliers (2000:33ff.). 
as it is witnessed to in Holy Scripture, seems to be diminished. In fact, the threefold hermeneutical structure, inclusive of the unholy trinity ${ }^{25}$ of fear-filled preaching referred to above, in effect take the promise of God's Presence in the present out of the present. This is not pre-sencing the Presence of God in the present, but rather 'pre-empting' the present as being void of the Presence of the Christ-event; 'pre-emptying' this present from coram deo. ${ }^{26}$ People act, and God must react. ${ }^{27}$ (The hermeneutics of fear 'usurps' the hermeneutics of promise.)

How then is this homiletical vacuum filled up? It is my contention that the 'empty now' is filled up, almost automatically, indeed by default, with the moralistic imperatives of religious activism. While some sermons sidestepped the challenge of preaching a fulfilled 'now' simply by means of 'silence, others endeavoured to fill up the 'now' with these 'moralistic imperatives of religious activism. ${ }^{28}$

This process of moralistic filling up is, almost always, accompanied by cliché. In fact, moralism and cliché could be called Siamese twins. The presence of cliché, expressed in repetition, simplification, and generalisation is usually a dead give-away of the presence of moralism, and vice versa..$^{29}$ Cliché excels in the usage of rhetorical techniques that represent efforts to fill up the empty spaces, that the speaker or preacher knows, consciously or subconsciously, lacks substance. In this way, the void must be covered up, must be presented as seemingly filled - although it is not.

In the sermon quoted above, endless 'repetition' (which should be distinguished from relevant and functional repetition), is indeed implemented throughout the sermon to deepen the atmosphere of fear. 'We are in a crisis!' becomes the rhetorical slogan, the sounding siren, manifesting itself as 'meaningless repetitions and accumulations' - to achieve 'effect.' Words alone are not trusted; therefore, words must be repeated endlessly.

The sermon also uses cliché that 'simplifies and trivialises complex ideas' by reducing them to 'stereotypes'. It in fact 'oversimplifies life', glossing over

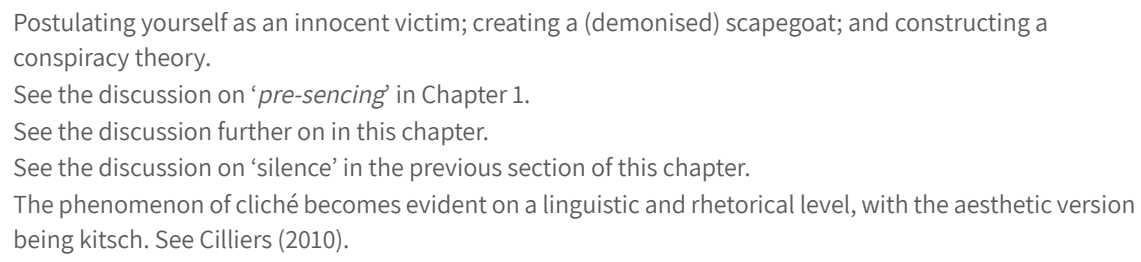


paradoxes - and therefore flatten out the hard edges of scripture, trivialising and domesticating it. ${ }^{30}$ In the process it becomes untrue and unfaithful to life, handing out recipes, guidelines for activism, instead of nuanced wisdom and ongoing discernment. In this sermon, the 'basic, simplified stereotype' is clear: we (the victims), are in opposition to them (enemies, backed by evil powers from without). No alternative can or in fact should be possible, or even thinkable.

The sermon grossly 'generalises' - an endeavour that inevitably leads to 'loss of true contextualisation. The 'situation' that the preacher wishes to address, in fact loses its profile, its sharp edge, being eroded and glossed over by generalisation. Reality is simply not as general like that - rather complex in its often-paradoxical multiplicity. When the preacher for instance states, as unassailable fact: "About this, experts of our time agree ...," he generalises, by presupposing unanimity amongst the 'experts' when it comes to their interpretation of the South African situation. The reality that there could be counter-voices, counter-opinions, is, at least in his mind, simply unacceptable. The so-called gravitas of these experts' opinions must fill up the gap, and therefore, they must speak with one voice - 'in times like these'.

There are of course, also other ways in which preachers try to compensate for an empty present, most of the times not even realising that these efforts could never be a substitute for the praesentia realis, the real presence of God in the present. It could be the way that rhetoric is used, or other means that must ensure (spectacular) impact. Even technology could be utilised to add 'flair' to the moment. ${ }^{31}$ Obviously, rhetoric, technology, and other modes of communication are necessary, even indispensable, but if these are understood as additions that are aimed to substitute the presence of God, or create the impression that all is well, sound, and relevant, it merely serves as a cover-up for the deeper dilemma: the absence of a Presence in the present. To put it rather bluntly: gimmicks, as such, have no gravitas, and cannot substitute God.

Cf. Brueggemann (1989:7).

By this, I am not saying that, for instance, technology, as it is utilised in the so-called 'network-culture' is not important. On the contrary, the communication of the Gospel always necessitates usage of the most effective modes of communication of the day - so it was from the very beginning of Christianity. However, if these modes become the focus in themselves, it could be an obstacle, rather than a vehicle, for the communication of the Gospel as God's Presence. For an overview of the realities and challenges of the network culture, see Barnard, Cilliers and Wepener (2014). 
In this regard, these pointed questions posed by Rudolf Bohren keep on haunting me:

Should we speak about God, when not only the gods, but also God is silent? Is God speaking, and do we have to speak about God, or is God silent and do we have to not speak about God? That is the question ... Our problem above all else is the absence of God in our speaking about God; our problem is that we speak about God, while God remains silent. ${ }^{32}$

To speak, or not to speak - that is the question. Or more fundamentally: to be present, or not to be present - that is the beginning and end of all preaching.

Other preachers from the apartheid era struggled with this in their own way, to fill up the vacuum of an empty present, a 'now' without Presence. Let us listen ...

\section{"Is history repeating itself ..."?}

In a second example of a sermon preached during the time of apartheid (preached on 11 November 1970, taking Nehemiah 4:14 as text), the preacher again uses all the three hermeneutical steps mentioned above to structure his sermon, particularly the situational analogy. He strives to parallelise the threat by the Samaritans on the Jews with the threat on what he first calls the 'church,' then the 'Christendom' and the 'Christian religion', and what he ultimately describes as 'the South African situation', and the 'pattern of life in our land' He does this with reference to the words of the text: "Don't be afraid of them. Remember the Lord, who is great and awesome, and fight for your brothers, your sons and your daughters, your wives and your homes."

The first paragraphs of the sermon determine the subsequent exposition of the biblical text. It sounds like this:

Times in the life of a church come when it must blow the trumpet without fear - or has to follow the more difficult path to its own downfall. In such times, the church must ask itself anew, in the light of the Word of God, where it is heading. And if it chooses the way of being faithful to its calling and to Scripture, then it must prepare itself for most aggressive resistance.

"Sollen wir von Gott reden, wenn nicht nur die Götter, wenn Gott selbst schweigt? Redet Gott und haben wir von ihm zu reden, oder schweigt er und haben wir von ihm zu schweigen? Das ist die Frage ... Unser Problem ist vor allem die Abwesenheit Gottes in unserem Reden von Gott, dass wir von ihm reden, während er sich verschweigt." Bohren (1980:33). 
In this struggle there will be journalists who will dip their pens in poison; trusting members who will be misled; as well as misunderstandings and quarrels, casting of suspicion and malignance.

And, if the church is driven out to the desert of isolation as a result of it taking a stand and stating its views, then it must remember that isolation, as such, is no sin. Two thousand years ago the Lord Jesus and his small group of followers were the most isolated community of that time - and of all times.

The first sentence contains an alternative that eliminates all other possibilities syntactically; strengthened with the compelling 'must' that is repeated three times, with rising tension, in the first paragraph. The preacher wants to point out the threatening 'downfall' and, by using the phrase 'where it is heading', suggests that the church has already taken the first step of the easier road of 'downfall'. Now, the trumpet is silent. The conditional construction of 'most aggressive resistance' illustrates the terrible situation, which linguistically plays out as: 'And if ... then it must' in which the 'church' must fulfil the condition. This is precisely the 'situation' that the preacher has in mind, for which he wants to prepare the congregation in the sermon, and which forms the one pole of his analogy.

The second and third paragraphs follow with a description of the 'struggle' in which the 'faithful members' will be 'misled' and the church will be 'driven out to the desert of isolation'. Here, the 'isolation' is the result of external reasons, as well as the fulfilment of (biblical) conditions by 'the church'. This is sanctioned when the preacher bases the inevitable isolation that comes over the 'church' on his view on Christology. The isolation of the 'Lord Jesus and his small group of followers' become the legitimisation for the isolation of South Africa with its 'pattern of life' as described further in the sermon. The implication is: isolation must come but is justified; God is for us in our challenge, and against all who isolate us and are against us. (For this, the 'Lord Jesus' is the ultimate guarantee.)

This justification for the preacher's understanding of the current 'situation' of South Africa is strengthened when the preacher brings the other pole of the analogy into focus. In this respect he makes two significant remarks:

And then, in a surprising way, a pattern of action follows that links Nehemiah's time and our own time. The past suddenly becomes the present, when the Samaritan strategy is described verse by verse. 
And now ... have I occupied myself merely wit $h$ a small section of antique history? Or are these patterns illustrated on the walls of our time? Are they written in the news columns of the papers of yesterday and the day before? Do we read it in the ecclesiastical manifests and theological documents of today? (Is 'history repeating itself', repeating itself with alarming consequences?).

The preacher intends to say: the attack against South Africa is nothing new; it has a negative parallel in the history of Israel. With the help of rhetorical questions, the congregation is informed of the possibility/reality of 'history repeating itself?. This places the preacher himself before a dilemma. If the current situation is precisely like in ancient times, does this imply that God will act precisely like God did then? Will not only history, but also God repeat Himself? Are God's actions determined today by this situation-analogy? If this is the implication, then the preacher runs the risk of falling into an automatist scheme and God=image. Then God is painted into the 'patterns' of history; indeed, then God becomes a patented God. Then this analogical, patterned construct holds the patent as an official right to be the only one allowed to make or sell this God-product for a certain period! At least on a linguistic level, i.e. if we take the words of the preacher seriously, this is a logical consequence of the analogy. (While some preachers sidestepped the 'now' through silence, and others tried to fill it up with moralistic activism, others ended up by filling the vacuum with a fixated, patented God - i.e. a God that could be handled, but ironically, was also understood as an 'anchor'.)

The 'intention' of this analogy schematism could indeed, again, be interpreted as being pastoral. Most probably, the preacher was not conscious of the patent-like God-image that his words constructed. The sermon possibly expresses the preacher's search for the Gospel, and, in this way, he wishes to evaluate and elevate the current time as a 'time of salvation'. It is quite remarkable to see how many times the preacher refers to time, e.g., "Times in the life of a church come ..."; "... the most isolated community of that time - and of all times"; "... Nehemiah's time and our own time ..."; "The past suddenly becomes the present ..."; “... the walls of our time."; “... yesterday and the day before ..., and so on.

Could this be an indication that he is indeed struggling to make sense of 'time'; to find significance in the 'now'? Probably. Yet, the fundamental structure of his sermon has exactly the opposite effect; in fact, it 'destroys' the significance 
of time as salvific time, by it affecting the relation between God and time in its core.

This relation between God and time (or of time before God: tempus coram deo) could be described as being 'dialectical'. ${ }^{33}$ In this dialectical relation, on the one hand, God enters time; on the other, God remains the Eternal One - God's Being is one of constancy and, at the same time, variation. This needs some further clarification.

On the one hand, 'God enters and works within time'. These works are so differentiated; God is so varied in God's epiphanies that the biblical writers must, for example, emphasise that it is the same Jesus who appeared in the fullness of time: Jesus Christ is the same yesterday, today, and until eternity. ${ }^{34}$ The 'strangeness', the incomparability of the Name of God, indeed, is coherent with this chequered way of appearing, with the fact that God indeed makes history, always new and surprising..$^{35}$ Like history, God does not repeat Himself.

On the other hand, God 'remains outside of time', as the Eternal One. Therefore, one must also emphasise that God is the 'Lord' of time and history, ${ }^{36}$ that God is the eternal King. ${ }^{37}$ God determines, divides and encompasses time, for instance ante et post Christum natum (before and after the birth of Christ). God sees through time, as the Alpha and the Omega, the One who is, who was and who is to come, the Almighty. ${ }^{38}$ Before God, there is but one time, and one day is like a thousand years and a thousand years like one day. ${ }^{39} \mathrm{God}$ inaugurates and closes the epochs of God's works among us. In the Holy Spirit God closes the book on certain periods of time and, in doing so, turns a new leaf of opportunity, creating new time: therefore 'from now onwards', we no longer judge anybody according to human criteria, 'now' we also no longer judge Christ in this manner. ${ }^{40}$

Both these sides of God's actions with us must therefore be maintained, i.e. God's in-timeliness, and God's out-of-timeliness. ${ }^{41}$ Indeed, God 'reveals'

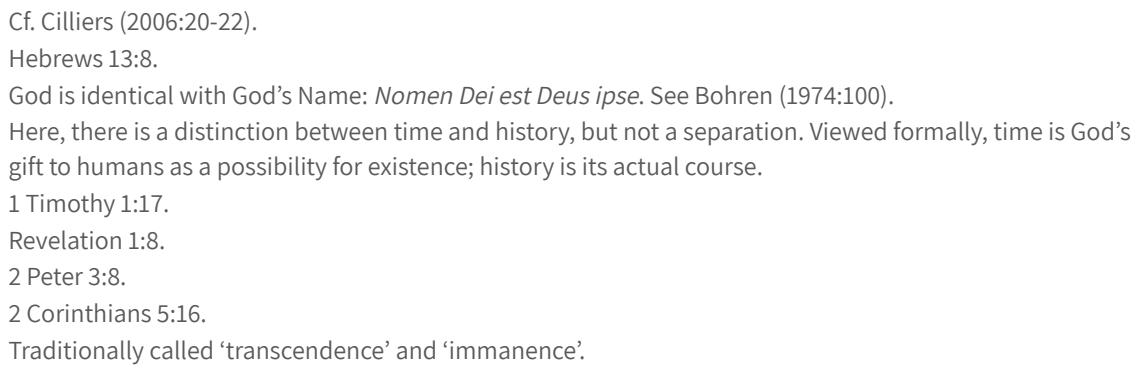


Himself in history, and this is a real revelation, it is God's 'Being' that is revealed to us; it is 'God Himself' who makes history in this revelation. Between God's Being and revelation, there is no tension. Yet, God is also more than God's revelation. God's reality is not dissolved in God's work. Because God is more than God's works, God can work; because God is greater than God's revelation and precedes it, God can reveal Himself. ${ }^{42}$ Neither has God, in God's revelation, been given to us as an item or idea that can be manipulated in our hands. God's Name remains a nameless Name. ${ }^{43}$

The acts of God in history (the caesuras of creation, covenant, the Christ event, Pentecost, etc.) underline the fact thatGoddoes not operateaccordingto so-called eternal repetition or tragic fate. For God nothing is fait accompli - especially not our states of hopelessness. God continuously puts up signs at the limits of our 'cul de sacs', saying: 'No Parking. ${ }^{44}$

Indeed: history does 'not' repeat itself, and God's image cannot, and should not, be frozen-in-time. God is on the move, in and through time, and God moves time ...

Let me put this in another way, taking the tension between cyclical and linear time referred to before, into consideration again. ${ }^{45}$ All the cyclical events that characterise our lives, events like birth and death, day and night, summer and winter, are not, indeed need not be, experienced as tragic. On the contrary, these cycles (circles) are constantly taken forward in time, by the God of time, the God that moves, and makes history within our cycles of life. (This moving God moves with us in the spirals of time that are taking us towards the telos of time. $)^{46}$

We are again reminded of Aristotle's belief that time and movement are inseparable. ${ }^{47}$ Homiletically - theologically - speaking, this could be interpreted as follows: God moves in time; God moves time; and - how utterly mind boggling - preachers are called to time the moves of this moving God. Preachers have the calling to pre-sense the Presence of the moving God in the present, in the 'now' - knowing all the time (!) that they cannot fast-freeze this God according to a patented image.

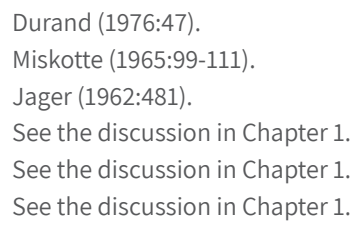


In preaching the so-called (eternal) cycles of fate should constantly be 'interrupted', even shattered by the linear movement of time towards the telos. ${ }^{48}$ However, this interruption also works the other way around - (tiring, never-ending) movement of linear time should also be 'slowed down', in order to allow moments of profound experience, within circles of community. We do move from past to future, but we do not, should not bypass the present, the now, in this process. This spiral communal understanding of time, I would call Kairos, and Pleroma, and it has, as already noted, got nothing to do with either the illusion of a 'fairyland time', or the fashionable mode of 'slow time.49

\section{God, how moving ...}

Perhaps all of this is, once again, understood better aesthetically. African art, as an expression of African aesthetics, comes to our aid. Van Troostwijk makes the interesting comment that African art, making use of basic human symbols like for instance circles (!) and human bodies (faces), and being closely interwoven with religion, actually is the 'mother of the theology.50

I restrict myself to a specific African artwork with a Christian content. Obviously, there are many aesthetic expressions of religion in and throughout Africa, crossing cultural, geographic, social, religious, and many other borders. From the rich oeuvre of Worku Goshu, African artist from Ethiopia, currently teaching in Addis Ababa, comes this work, dating back to 1981, and titled, Resurrection. Obviously, there are many interpretations possible, even necessary, of this work of art. ${ }^{51}$

I find this depiction meaningful in terms of the relationship or tension between linear and cyclical time that I have been referring to in this book. But more than that: it also brings into picture the notion of community, and the fluidity of God-images, in an imaginative manner. Movement and community, time and space, come together ...

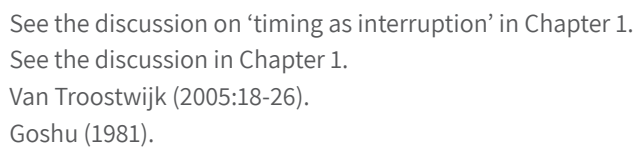




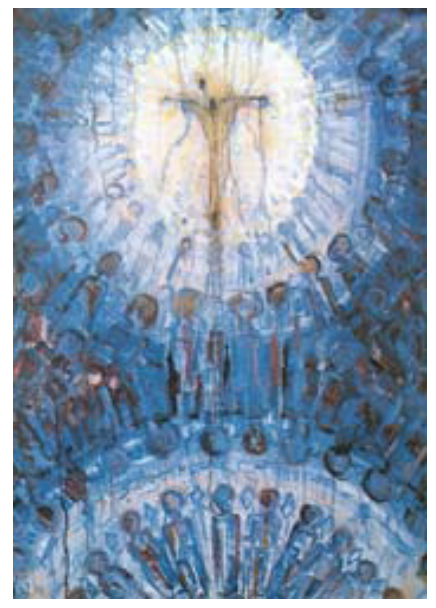

Figure 3.1 Worku Gosh, Ethiopian artist's Resurrection (Goshu, 1981)

This artwork opens an intimate space of divine Presence, with a central Christ-like symbol emanating light. ${ }^{52}$ But, the symbol is also vague, in a sense decentred. It represents (i.e. reimagines) a decentred Jesus, escaping any form of encapsulation. The figure of Christ still resembles the cross (i.e. a fixed, historical event, taking place within so-called linear time), but also, paradoxically, signifies movement. (This is indeed a Christ-on-the-move, being resurrected - rising above and beyond historical fixations.)

One furthermore immediately sees the circles: one surrounding the figure of Christ, but also many others; as a matter of fact, one senses that these circles are only the first beginnings of a multitude - the circles, and consequently the whole picture, flow out of the frame, so to speak. It reminds of a pebble, striking the pond, sending ripples in all directions ...

One could ask why the circles play such an important role in this depiction, as is the case in many other forms of African art. The answer is deceptively simple, and astonishingly profound: A circle does not have a beginning or an end. It cannot be stretched out in a linear pattern of past, present, and future. In this sense, it offers a corrective on the experience of the exhausting flight of time (tempus fugit). It slows time down, clipping its wings, so to speak, preventing it from taking off again.

52 See Louw (2014:293). 
These circles are different from the eternal circles that signify tragedy and fate; here they are understood 'not' as exclusive entities with eternally fixated predestinations or characteristics, but as circles that have been opened up, that have been brought into movement by the 'line' of time (past to present to future), understanding full well its own inherent transience. And, I will contend that all of this has been made possible by the central God-image-on-the-move, resulting in communities-on-the-move.

These circles indeed also signify real community, real security within the community; a sense of belonging within the cycles (circles) of life and death. Here, the 'other' is not feared; rather incorporated. But, importantly: the circles are not separated from each other in a watertight manner; they do not represent exclusive enclaves. On the contrary, it seems as if the circles are interlocked, are flowing into one another (see the way that the circles are connected in the middle of the painting).

These circles are not cold and hard; not keeping out, but inviting in. They are constituted by human-like figures, representing the community of people being drawn into the wide and welcoming space that the Christ-like figure opens.

The use of colour enhances this experience of space: the light surrounding the Christ-figure resembles not only the circular shape of the sun, but also signifies the warmth that gives life to all. The use of blue enhances this notion of an inviting, warm, life-giving space: it breathes the atmosphere of the open, wide, African skies ... where the sun (almost always) shines on all and everybody on this continent.

Would it be too much to say that both Christ and people move in this space? There is nothing static, nothing monumental about them. On the contrary, this represents a God that moves, and in the process, moves all and everything. Indeed, here 'God is not a monument, but movement'. ${ }^{53}$ God, (not) needing time and space, moves through time and space. God moves within the realms of culture, cosmos and the dynamics of human relationships. God is the God of the tabernacle, the tent of transit, not the gravity of granite..$^{54}$

See Cilliers (2015:1-13).

54 Accounts of God's presence in the Old Testament shows an interesting tension between what has been called 'locative' and 'non-locative' models of Divine presence. Some scholars even opt for a description of the Divine presence as 'locomotive': there is a sacred centre, but it moves constantly between centre and periphery. According to Sommer: "When set against texts that glorify the Jerusalem temple, the priestly tabernacle appears to express a different notion of Divine presence. The tabernacle, after all, is not limited to one place, for it wanders with the Israelites. Thus, Divine resence texts, in comparison to the Zion/Sabaoth theology, seem not locative but what I would describe as 'locomotive': there is a sacred 
In short: This artwork represents a form of 'fluid time and space' that acts as a type of contra-testimony to fixed time and space. It offers a striking, African depiction of a God-image that has the 'metaphorical-theological function of constantly liquefying time and space', representing a stance against any form of crystallised, fixated, or power-seeking religion. ${ }^{55}$

To understand this liquefying of time and space, preachers need to understand 'timing as an osmotic event', as stated earlier; they need to view preaching as a form of timing that allows itself to be informed by porous hermeneutics, that is constantly challenged and enriched by the inter-flow of time, space, community - and the moving God. ${ }^{56}$ It would seem as if the depiction above breathes with osmosis, pulsates with the surprising flows of porous hermeneutics, in fact, comes alive with the pre-sencing of the Presence of the moving God, in the present - in such a way, that we are invited to be taken along (communally) in this movement.

Indeed, because God moves, we also move - we are taken along in the movement of this God of liquefied and liquefying history, 'this God who does not repeat history'. Even more unsettling: preachers that propose to preach (about) this moving God, should know that they are constantly called upon to create God-images, but simultaneously, to dismantle them. (Preached God-images are set up to be broken down; are imagined to be re-imagined; are made to be moved.)

This could indeed be an unsettling thought for preachers to ponder: God-images are images that cannot, and should not be controlled, secured, or encapsulated in time.

Preachers do 'not' have the ultimate responsibility or indeed capability, to keep and uphold God's images ...

Personally, I find this liberating, beyond words ...

centre, but it moves. The axis linking heaven and earth (or at least heaven and the nation Israel) is an ambulatory one. The locomotive model, then, combines aspects of locative and Utopian ideologies: the centre moves towards the periphery, while points in the periphery can become, temporarily, a centre." Sommer $(2001: 48,49)$.

55 In thissense, theology is notso much a noun-theology, as a verb-theology: God's Name is A Name-on-the-Move. Cf. Niehaus (1992:3-30). This understanding of God's Name as movement implies that the movement is not haphazardly - although it may seem like this from time to time. The movement of God has a direction; the moving God is headed, with us, towards a 'telos'.

56 See the discussion on 'timing as osmotic event' in Chapter 1. 


\section{“Crossing the Jordan ..."?}

As we have seen so far, in their efforts to find security in the time of apartheid, some preachers sought to fill up the present with religious activism, or to construct historical analogies that presupposed that history repeats itself, and God-images that served this presupposition. Then, apartheid ended. A new dawn seemed to be breaking over South Africa. A new time was at hand. We were busy 'crossing the Jordan'. Let us now listen to a sermon, preached shortly after the first general democratic elections took place in South Africa. ${ }^{57}$

First, again a few words on the 'time of apartheid' - which forms part of the backdrop, against which the sermon was preached. This era in our history could be described as legalised isolation and enforced exclusion of designated groups. For centuries, from the times of colonialism, South Africans were kept apart in various ways - and in the time of legalised apartheid, they were also separated in a 'geographical fragmentation' of the country, with the fragments euphemistically called 'homelands'. South African citizens were separated, and society fragmented not only on beaches, train stations, public amenities, workplaces (so-called 'petty apartheid'), but more importantly also in the spheres of political power and economic affluence ('grand apartheid').

The release of Nelson Mandela, lead to the first democratic general elections, held on 27 April 1994. ${ }^{58}$ This dramatic event was hailed across the globe and scenes of seemingly unending queues of people waiting their turn to vote - the majority of them for the first time in their lives - were splashed onto television screens for millions to witness. It seemed like the end of legalised fragmentation: the dawn of a new era of unity, reconciliation and connectedness..$^{59}$ South Africa once again became part of the international community, experiencing the fruits of the 'video-sphere' with its technological networking by means of the internet, television, cell phones etc. - so that one could say that, at least on a technological level, we were no longer fragmented, but rather 'enabled to become part of the connected globe.60

57 What follows is a revised version of Cilliers (2012a:1-12).

58 Time and space constraints do not allow me to describe the momentous events leading up to this breakthrough in detail. For an overview of this period, cf. Giliomee and Mbenga (2007:330ff.).

59 This is perhaps best epitomised by the events of the Rugby World Cup in 1995 (when South Africa was crowned as the world champion) and again by the Soccer World Cup (June 2010), being hosted by South Africa.

60 Cf. Debray (2000:166). Television, for instance, was withheld from South Africans until as late as 1973. 
Obviously, this fundamental reconfiguration (or 'defragmentation') of our society also found its way into countless theological debates and analyses, before and after the elections. It was articulated in thousands of sermons, South Africa being a religious ${ }^{61}$ country with a myriad of churches.

As an example of these homiletic reflections, we listen to a sermon that was delivered in a radio broadcast by a Presbyterian minister ${ }^{62}$ from a middle-class suburb near Cape Town on 29 May 1994 - about a month after the April general elections. This sermon was preached in the immediate aftermath of one of the world's major political attempts to create unity within a country renowned for its fragmentation. Speaking metaphorically, we were indeed 'crossing our Jordan', moving out of our spaces of former fragmentation into a space of unification. It was (our) time.

This book is being written twenty-five years after the sermon was preached and obviously certain things have changed in the process of rebuilding our country and reconnecting to the international community. Although, it could be argued that many of the issues of apartheid are still with us, haunting us, and might even have intensified. Twenty-five years later we are still fragmented in some regards, with issues like the redistribution of land without compensation causing emotional divides - to name but one instance. On the one hand, we 'are' connected - South Africans carry more cell phones per person than those in many other African countries! On the other hand, we still seem to be disconnected in many ways. The question is: did sermons like this one help us in our time of transition? Did they launch us on a path of healing, or the contrary? Let us listen ...

According to Pew Research Centre (2017), 81,2\% of South Africans are Christians.

For the sake of anonymity, the name of the preacher is omitted. 


\section{Crossing the Jordan}

The Scriptures abound in examples of men and women who took God at his Word. God said it and they believed it to be true. Despite context, the conditions and circumstances they never failed to put their trust in God. Now let us not for any moment believe that they had it easy. In fact, they suffered more than we can possibly imagine but they never gave up on God. Why? Beause they knew God, they knew that they could trust Him; they knew that they could depend on Him. Can the same be said about you and me this morning? That no matter what we're going through in this life right now we will not be shaken or uprooted from our position in God. But like the psalmist in Psalm 46 we will find our refuge and strength in God our Creator.

The writer to the Hebrews in Chapter 11 commends people like Abraham, Noah, Moses and Enoch as the champions of faith, as those, who despite their adversities, surrendered to God in hope. In fact, for most of them, their situation was indeed of nothing less than a miracle. The Jordan story we read this morning is another example of the miraculous working power of God amongst the people of Israel. It's a story of how God cares for his people, of how God rescues them out of bondage and of how God sets them on a new path of discovery and hope.

Perhaps we as South Africans can understand that today. For many in our country the present transition is nothing short of a miracle. Who would have believed that in 1994 we would have seen changes that we are now witnessing in this country, in our government as a whole? Indeed, the days of miracles are not yet over. We may have stopped believing and trusting in God in the measure of those people of Biblical times, but God is still very much present and very much alive today in the world. The world may be modern, and our perceptions of God may be changing with the modern world, but the good news is that God is still the same - yesterday, today, and forever. Though it may change, but Jesus - never!

The Jordan story is one example of the miraculous activity of an unchanging God. It suffices to tell us where God works, how God works, when God works and why God works. But more importantly, it serves to tell us how 
a people among whom God works are moved and prompted to respond in faith.

Getting back to the Jordan story then, we find the people engaged in a determined but in a somewhat impossible destiny. They wanted to break free from a land of oppression and exploitation and enter the Promised Land where they could establish a city of God. But they realised that they could not do this on their own human strength. They needed God's divine intervention. Perhaps this answers the question on where God works. He works wherever there is a need, especially wherever there is a need for Him to be recognised, accepted, and appreciated as God. He's always at work, bringing people to faith and transformation. The gospel writer Matthew tells us in Chapter 8 that Jesus is always there in the middle of the storm and what is the purpose of Him being there? To bring peace and calm. Maybe you have a serious need right now; maybe you are experiencing a storm in your life right now. My plea to you this morning is this: do be assured that Jesus is with you. He is there, restoring peace and calm in your broken life.

Let's tackle the second question: How does God work? The Bible tells us that He works in a variety of ways. The Elijah story tells us that God works in a whisper. The psalmist tells us that God works in a thunderstorm or in an earthquake. But the Jordan story this morning tells us that God stills the waters, divides the seas and breaks down the walls of oppression of whatever kind. Through the Spirit God is at work in your life right now, right this minute.

That brings us to our next question: When does God work? The Bible tells us that God does not work under force or pressure. On many occasions Jesus is compelled by the crowd to show signs bearing testimony to his claim that He is the Son of God. But in each given moment Jesus refuses to do so. There is one fact that Jesus establishes in all of this and that is that God works in 'his' time. Sometimes we must painfully discover that for ourselves. Our desire to get quick answers is often frustrated by what seems to be God's slowness in responding to our needs. Moses and Joshua can ask of God, but they must trust Him, and wait. The same is of course true for you and me today.

Let's then look at the last question: Why does God choose to work amongst us? The Bible tells us that it is his intent on reconciling us unto Himself. He 
wants to encourage faith in us so that we might trust Him. He wants us to embrace his Lordship.

But what does the Jordan story have to say to us this morning? Friends, I believe that each of us, whether we know it or not, whether we admit it or not, whether we have seen it or not, have a Jordan to cross. The Jordan I am talking about is the pain, suffering, and hurts of life. Jordan represents the impossibilities. Jordan represents those moments in which we need divine intervention. Jordan refers to the situations which require nothing less than a miracle. In the words of CS Lewis: Jordan refers to those moments when we say: "Lord, there's nothing I can do. I'm depending on You." Jordan is not necessarily 'giving up' in as much as it is 'giving over'. It's taking God at his Word. It's trusting God for the future. Jordan means crossing the frontiers of the known into the borders of the unknown.

Perhaps that is exactly what we are doing in our country right now. Many people are very anxious and nervous about the New South Africa. They are afraid of the unknown. We are not certain about so many things - about the security of our jobs, about our properties and businesses. We are afraid of losing our power, influence and privileges as a people. Yes, we are crossing the Jordan and it is painful and difficult. There are many of us who are crossing from the known into the unknown zone in life. Perhaps you want to change your job, but you are not certain of whether you are doing the right thing. Maybe you want to buy a new house, but you are not sure whether you can afford it in the long term. Maybe you want to enter a marriage, but you are not sure if that's what you really want in life. Maybe you want to reconcile a marriage that is already broken but you are not sure whether it is going to work out again. You want to change your lifestyle, but you are not sure whether you will survive the changes. You want to improve the home situation, but you don't know if it's going to work out in the end. Yes, we cross the Jordan of uncertainty almost every day of our lives, don't we? In fact, many of us are probably already saying 'It's going to take nothing less than a miracle to save my marriage, my business, my family, my home, my house, and my life.' But friends, let me assure you this morning that God is in the business of miracles. You thought that dividing the sea was scientifically impossible, right? Wrong! It's possible with God. God is the God of all impossibilities. God can take the worst and turn it into his very best. God can take your impossibilities and turn them into probabilities. He wants to do that for you, right here, right now. 
Jordan, then, does not represent uncertainty and fear. Instead it stands for hope and faith. Joshua trusted God. When God told him: "I will take you and my people with you across the waters of the Jordan." Joshua did not stop to ask if that was scientifically possible. He knew his God. He trusted in his God. And so, it is that Scripture tells us that no sooner they touched the water's edge, the waters divided. The faith that Joshua expressed and exercised was not a foolish faith but a believing faith. Do you have such faith to believe that God will rescue you no matter what your situation? That God will save your home, your marriage, your business, your job and our country? Friends, Joshua was not afraid because God went before him. In verse 14 of Chapter 3 we read that the Ark of the Covenant of the Lord went ahead. How are you crossing your Jordan today? Is it alone; is it on your own strength? God wants to go before you. God wants to lead you. God wants to help you.

Psalm 27 says: "The lord is my light and my salvation; I will fear no one. The Lord protects me from all danger; I will not be afraid." God wants us, like the champions of faith, to be sure of what you hope for and certain of what you do not see. The gospel writer Matthew tells us the same in Chapter 6:25 following. He says that we should not be worried about what we will eat, what we will wear, what we will drink. Instead we should put our trust in God, and He will see us through. Why? Because God is in control.

A joke is told about a man who fell down a cliff. Fortunately for him, he managed to grab onto a branch of a small tree. He couldn't move or do anything to save himself from falling further to the bottom. So, he looked up and prayed to God for help. Then a faint voice came: "Let go." The man looked up and again a voice said, much louder: "Let go." The man looked up, he looked down again and he looked up again and then he shouted at the top of his voice: "Is there anybody else up there?" Friends, crossing the Jordan means letting go and allowing God to take over. But faith in God does not mean resigning. Instead it means reassigning. Not looking to oneself anymore but depending on God, assigning the task to God.

The Jordan story tells us what we must do. So right now, you are in life's deep end and you are asking: 'What must I do to cross this Jordan?' Let's see what God says to Joshua and his people. In verse 3 of Chapter 3 the leader said to the people: "When you see the Ark of the Covenant of God you are to move out from your positions and follow it." You see, my friends, the Ark represented the actual presence of God. So, what they were really 
saying is this: 'You must follow God.' Friends, this is my advice to you as you cross your Jordan this day. Move out of your positions of depression, hopelessness, security, fear, discomfort, and sadness and follow God. Trust God. Very often people with problems get preoccupied with themselves. They narrow and limit everything to their depressing circumstances. When crossing the Jordan, we must learn to see beyond ourselves. We must see the Triune God.

But following God involves a little more. In verse 5 the leaders said to the people: "You must consecrate yourself to God," meaning that they must give themselves to God most completely. Friends, as you cross your Jordan I implore you to do the same, to embrace the Lordship of Jesus Christ, you give yourself to Him most completely, to know for sure that He can and will see you through, to know that He is powerful and most able to carry you through the rough seas of life's experiences. What happens when you consecrate yourself to God? In verse 5, continued, we read: "The Lord will do amazing things among you." So, you see, friends, when you commit your life to God that's precisely what you will see. Things may not necessarily change for you, you may still struggle to pay the bond, you may still suffer the loss of a loved one, you may still suffer with the sickness of alcoholism, your marriage may still end in divorce, you may still not be satisfied with the way things are going on in this country, but in all that you will not be alone. God will be your strength and refuge, your ever-present help in trouble. And therefore, you will not fear, though the earth gives way. You will say with the prophet Habakkuk: 'I will rejoice in the Lord of my salvation.'

Friends, you cannot cross your Jordans alone. Not on your own strength. You need divine intervention. You need God to put you on a new path of discovery, recovery and hope. Perhaps that's what you need right now. Maybe you have forgotten God. Maybe you have given up on God. Maybe you don't know God. As you cross your Jordan God's invitation is still open to you right this very minute. He says: "Call unto me and I will answer thee. Come to me and I will in no way cast you away." I trust that's what you will choose to do - to invite Jesus into your life. If you should desire that right now, why not say this prayer with me. Let us pray:

Lord Jesus, I invite you into my life. I know that I cannot cross my Jordan alone. I confess my need for your divine presence. Father, Son and Holy Spirit, work your miracle in my life right now as I entrust myself to thee. Amen. 
In what follows, I offer an in-depth analysis of this sermon, utilising the Heidelberg Method. ${ }^{63}$ This method aims to disclose the 'fundamental hermeneutic structures' of sermons. In the following analysis, I will focus ${ }^{64}$ on this, while also venturing a 'theological interpretation'.

\section{The God of the past}

At first glance the sermon ${ }^{65}$ looks inspiring and comforting (i.e. theologically 'correct'), indeed like a word fitting the times. However, deeper analysis of the fundamental hermeneutic structure reveals that there is more going on beneath the surface than meets the eye. The sermon takes as its text Joshua 3:1-17, which depicts Israel in transit, on the point of crossing the river Jordan, and then uses it to draw a parallel with a South Africa that faces an uncertain future, wherein property, political power, security of jobs and businesses are threatened. ${ }^{66}$ Against the backdrop of these uncertain times, the congregation is called upon

63 Briefly put, the Heidelberg Method could be described as follows: the method originated from research done by homiletical study groups at the Practical Theological Seminary of the Karl Rupprecht University of Heidelberg, Germany, during the late 1970s. After the theoretical basis had been formulated, it was published for the first time at an international symposium on preaching held in Heidelberg on 8-12 October 1986. Here the Swiss practical theologian Rudolf Bohren, the German author Gerd Debus, and others shared their experiences in applying this method with a broader homiletical community. It can be called an intra-textual approach, which intends, by means of a 'close reading' of sermons, and by implementing rhetorical and theological criteria, to interpret the Word of God in, and often against, the preached Word. Simply put, it asks: to what extent does the preached Word articulate the Word of God? Or in Bullinger's definition: is the preached Word of God indeed the Word of God (preadicatio dei est verbum dei)? As an analytical method it naturally represents a framework of interpretation. Its intention is therefore not to be the final word on specific sermons, but rather to open a dialogue concerning these sermons. It wishes to serve the maturing of preacher and congregation, the latter to its full stature as complete church (ecclesia completa), a church that has both the ability and right to judge the preached Word (Luther). It therefore literally takes preachers at their word(s), trying to truly understand them, sometimes even up to the point of understanding them better than they understood themselves; trying to grasp the pivotal, and often subconscious hermeneutical decisions which underlie their sermons. In doing this, the most basic questions are asked, such as: How is the biblical text implemented in the sermon? What congregation is presupposed and/or invoked? What role does the preacher play? And, of specific importance for this book: 'What (kind of) God is pictured in the sermon?' (cf. Bohren and Jörns (1989:55-61). There are of course also other methods of sermon analysis, for instance the Heidelberg model with the use of the Kwalitan computer program; the hermeneutical model developed by Vaessen (1997); the model for researching the sermon as a Word of God by Stark; the combination of the Heidelberg model and Stark's model by De Klerk, De Wet and Letsosa; and the grounded theory model for inductive analysis of sermons in order to develop a theory from the data. For an overview of these approaches, cf. Pieterse (2010:1-16).

64 This implies that not every sentence and/or word of the sermon is necessarily reflected in the analysis. Obviously, the preacher also says some moving and noteworthy things, but to such extent that they do not impact on the basic hermeneutic structure, they are not mentioned or analysed.

65 The sermon represents a verbatim reproduction of the sermon as it was preached. It has been numbered in the left column for easy referencing. Direct quotations are in quotation marks. 
to trust God; ${ }^{67}$ to acknowledge and accept $\operatorname{God}^{68}$ since they need - as was the case with Israel facing the Jordan - God's "divine intervention". 69

The sermon is characterised by 'two tensions', the first obvious and on the surface, so to speak, the second somewhat hidden, but nonetheless dramatic and essential for the understanding of the hermeneutical structure of the sermon. The 'first tension' flows from the preacher's assessment of the South African transition. Looking back at the election of April 1994, i.e. 'historically' speaking, the preacher can describe what has happened as "nothing short of a miracle". ${ }^{70}$ None other than 'God' has delivered us from "oppression and exploitation".71 Looking to the 'future', however, the preacher speaks for people who are nervous and uncertain, en route to an unsafe, unknown destination. ${ }^{72}$ For them the transition is "painful and difficult", ${ }^{73}$ not without "dissatisfaction with the way things are going on in this country". ${ }^{4}$ While the past provides much reason for gratitude, the future constitutes an impossible destiny. ${ }^{75}$

The 'second tension' in a sense runs parallel to the first. Looking back at the great deeds of God with regards to Israel (again: 'historically' speaking), as they are proclaimed in the biblical text, the preacher can stress the 'initiative of God' resulting in the faith of Israel. "God said it and they believed it to be true".76 That is the order, the (theological) sequence of events. Quoting from Hebrews and Joshua, the preacher underlines the "miraculous working power of God amongst the people of Israel,,$^{77}$ how "God cares ... rescues ... sets them on a new path" ${ }^{78}$ What God 'has done' (in the recent past) in South Africa is cited as yet another example of this miraculous initiative of God - so much so that the order: God acts and people respond, is now reduced to God's initiative alone: "We may have stopped believing and trusting in God in the measure of those people of Biblical times, but God is still very much present and very much alive today in the world" ${ }^{79}$ This is indeed the preacher's basic intention in his

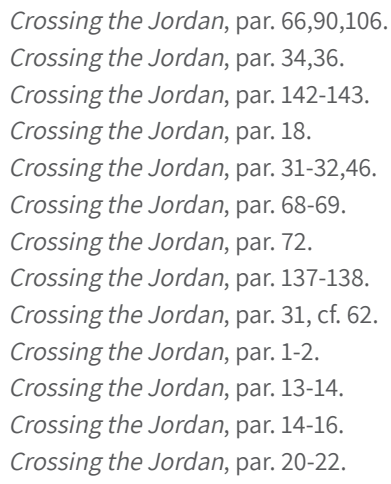


sermon: to elevate the faith of his listeners to "the measure of those people of biblical times", to transform them into "champions of faith". ${ }^{80}$ One could say he intends to 'empower and enable' them to achieve the level of faith of these biblical examples.

\section{The God of the future}

In order to achieve this, he asks four questions, taken from the example of Jordan, and once again he confirms the sequence: "How a people among whom God works are moved and prompted to respond in faith" ${ }^{81}$ It is interesting to note that the first three of these four questions (where, how, when and why God works) ${ }^{82}$ are all answered in an indicative fashion, ending in a personal note in the present tense, for example: "Jesus is with you. He is there ...; "Through the Spirit God is at work in your life right now, right this minute"; "The same is of course true for you and me today".83 But then comes a 'telling switch': the last question does not end in the present, indicative tense, but as a 'future possibility': "He 'wants' to encourage faith in us so that we might trust Him. He 'wants' us to embrace his Lordship." Now we hear of God's “intent".84

Why this sudden change in tense? A possibility might be that the preacher 'wants to prepare the listener for the second part of his sermon' in which he 'applies' what he has said so far to people living in uncertain times and facing an uncertain future. Therefore, the break and contrast affected by 'but', as he states: "But what does the Jordan story have to say to us this morning?" 85 ('But' forms the bridge between God's deeds and God's intent, signalling the tension between what God has done and what God wants to do in South Africa in a time of transition.)

The second part of the sermon indeed slants towards the future, stressing 'possibilities'. This is expressed grammatically in a flood of future tenses. A few prominent examples: 'God 'can' take the worst and turn it into his very best. God 'can' take your impossibilities and turn them into probabilities. He 'wants' to do that for you, right here, right now"; "He 'can' and 'will' see you through ..."; "God 'will' be your strength and refuge," etc. ${ }^{86}$ Perhaps the best

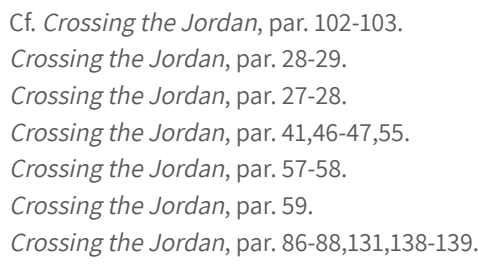


example of this 'tension between salvation history and salvation possibility' can be found in the biblical text, where the preacher states: "Friends, Joshua was not afraid 'because God went' before him ..." Addressing the congregation, he says: "How are you crossing your Jordan today? Is it alone? Is it on your own strength? God 'wants' to go before you. God 'wants' to lead you. God 'wants' to help you." ${ }^{87}$ One could say, with due respect, that God is put on hold. God 'wants' to act, but apparently does not. Why? Something must happen first; certain conditions must first be met. But what are they?

\section{Homo intactus: the human of the hour}

The listener must first act. Between God's acts in the past and God's acts in the future stand the acts of the congregation in the present. Therefore, it is quite logical that the preacher continues and starts the 'third part' of his sermon with: "The Jordan story tells us what we must do." ${ }^{88}$ Now the emphasis no longer falls on what 'God has done' according to the Jordan story, but what 'we must do'. Indeed, 'while the present indicative dominates the first part of the sermon, and the future tense the second, the imperative now structures the third. The preacher repeatedly says: "you must ... we must ... we must ... you must." ${ }^{89}$

If I am not mistaken, and this is not said lightly, the preacher falls prey to a fatal trap of 'religious activism, ${ }^{90}$ born out of an inappropriate God-image. I believe that he does not do this deliberately. His bona fides should not be questioned; in fact, as preachers we probably do not have the conscious and deliberate intention to proclaim lies (Augustine: mendacium est enunciato cum voluntate falsum enuntiandi). ${ }^{11}$ We should have sympathy with the preacher. The difficulties in crossing the 'Jordan in South Africa', here and now, ${ }^{92}$ the pressures of the present, ${ }^{93}$ cause the preacher to interpret, albeit subconsciously, this present as a 'vacuum between God's deeds and God's probabilities, ${ }^{94}$ a vacuum

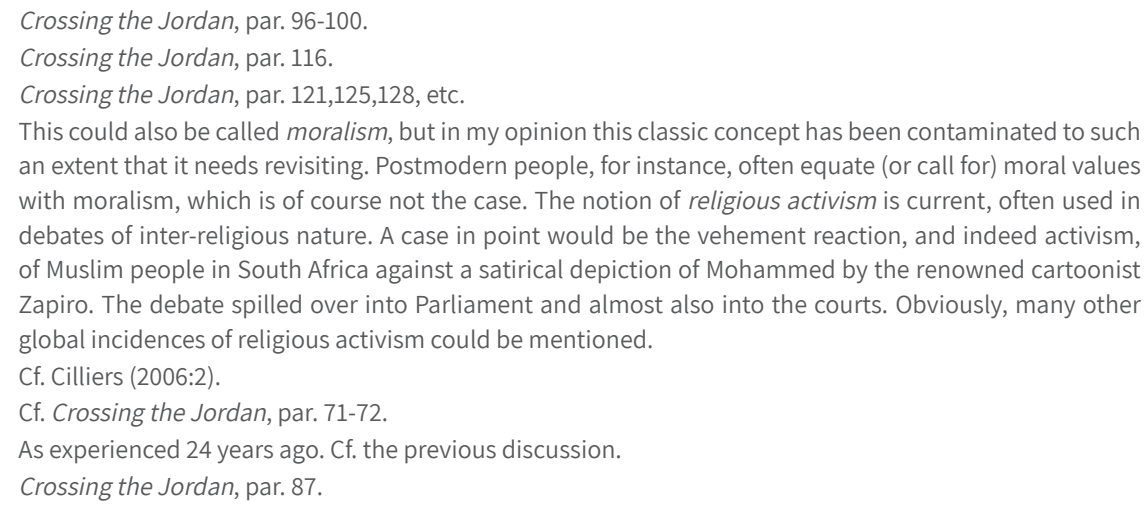
an extent that it needs revisiting. Postmodern people, for instance, often equate (or call for) moral values with moralism, which is of course not the case. The notion of religious activism is current, often used in debates of inter-religious nature. A case in point would be the vehement reaction, and indeed activism, of Muslim people in South Africa against a satirical depiction of Mohammed by the renowned cartoonist Zapiro. The debate spilled over into Parliament and almost also into the courts. Obviously, many other global incidences of religious activism could be mentioned. 
into which steps none other than the religious human being (homo religious), who is also an intact human being (homo intactus). This human being must now salvage the precarious state of affairs. Through his and her choices ${ }^{95}$ the future - that which God wants to do - will indeed be like the past - that which God has done. This 'intact, religious human being' must ensure that past and future coincide in the present. In effect God's acts hinge on what the listener 'must' do in the present.

This is stereotypical of religious activism, stating what God has done and what God will do, but more importantly: what people must do to activate God's deeds now. ${ }^{96}$ In principle, or at least 'linguistically', it leaves the present devoid of God's acts. Ironically the preacher goes to great lengths to stress the fact that God and Jesus never change, that they are "unchanging". ${ }^{\text {. B }}$ But the preacher's dogmatic confession about God is short-circuited here by his homiletical methodology. God in fact does change, or rather: is changed by the sermon from present and active to absent and inactive. This image of the absent and inactive God' is underlined by the stereotypical structure of religious activism, which could be described in a nutshell as follows:

» God did (in the past)

»God wants to (in the future)

»We must (in the present). ${ }^{98}$

\section{Disabling God in an able world?}

But one could ask, is God not present? Of course, God's presence should not be understood in a mechanical or deterministic way. God's presence is always an 'elusive, moving presence'; God's revelation is always also an act of concealing. ${ }^{99}$ God is, simultaneously, a deus revelatus and a deus absconditus. God is often revealed in paradoxes - even as One wearing masks. According to Luther, every part of creation in fact forms part of God's masquerade (Ideo universa creatura eius est larva dei) ${ }^{100}$ But this is not what is at stake here. In sermons like these, God is 'taken out of the picture' by human beings. God suffers subordination according to the conditions of human beings, suffers 'anthroponome subordination. ${ }^{101}$ The actions and abilities of human beings,

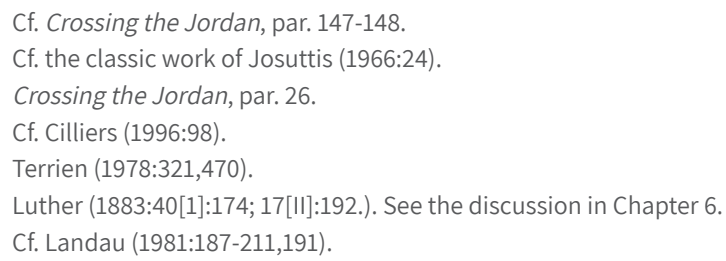


which are ironically intended to activate God, in fact disable God. Religious activism could in this case be called 'the act of disabling God by means of religious rhetoric'. The preacher is so influenced by the paradigm of (or in this case: the longing for) an empowered and enabled ${ }^{102}$ post-apartheid South Africa that the fundamental hermeneutical structure of his sermon disables God. The religious activism of the homo intactus results in the depiction of an 'incapacitated and disabled God'. Again: this is not said lightly. On the contrary.

The way in which the preacher steps into the activist trap of 'disabling God by means of religious rhetoric' is nowhere better seen than when the preacher prepares the listener for what is to come, ${ }^{103}$ by first asking "a little more" of the congregation (euphemistically?), and then quoting Joshua 3:5 to substantiate this. ${ }^{104}$ In the process, the quoted text is twisted ever so slightly, given a seemingly innocent but altered nuance, with far-reaching results. The preacher states: "You must consecrate yourself to God ... What happens when you consecrate yourself to God? The Lord will do amazing things among you. So, you see, my friends, when you commit your life to God that's precisely what you will see." ${ }^{105}$

The biblical text of course does not say this. Although the text 'does' speak about consecration to God, as the first part of the preacher's statement articulates, it is the second part of his statement that derails the intention of the text. Joshua 3:5 says: "Purify yourselves, 'because' tomorrow the Lord will perform miracles among you." 106 In his eagerness to fill what he senses as a vacuum between past and future, the preacher changes the preconditioned action of Israel into a conditional action, which must be duplicated by his hearers. A homiletic slip takes place between the cup of the text and the lip of the preacher, with devastating effects. God's action now 'depends' on whether we can purify ourselves "most completely". ${ }^{107}$ 'Because'108 now becomes 'when'.

102 The notion of an 'able world' comes into play here: in a consumerist and market-driven society, weakness, failure, and lament have no place. Success is the key word. Arbuckle finds this mentality a sad state of affairs and contends: "This is a thoroughly pathetic and frightening picture of a death-denying culture, for just as we seek to deny physical death, so also we are apt to ignore all kinds of painful personal and social loss. We have developed a pervasive mythology in which success is the hallmark of Western identity and failure or loss has no place in it." Arbuckle (1991:44).

103 Crossing the Jordan, par. 127-135.

104 Crossing the Jordan, par. 127.

105 Crossing the Jordan, par. 127-135.

106 Good News Bible.

107 Crossing the Jordan, par. 128-129.

108 The Hebrew word for because, $k \hat{l}$, is a particle which means - because, for, when. It denotes reason, in this case because of the acts of the Lord. The temporal possibility (when) is also linked to the active subject, the Lord. 
Theological 'grounding' is changed into activist 'temporality'; 'God's initiative' is transformed into 'human timing.' ${ }^{109}$ This form of timing stands in stark contrast to what I propose in this book as the 'timing of grace."10

Of significance here is the use of the superlative. Extensive sermon analytical studies have shown that superlatives and tautologies are often characteristic speech-patterns of religious activism. ${ }^{111}$ The implication is disheartening (not comforting, as the sermon suggests at first glance). It could even be called cruel: must we consecrate ourselves 'most' completely - 'before' God can act? Surely not? It could even be called a form of 'sermonic pathology': to manipulate (activate) people to activate (manipulate) God, i.e. to utilise an inappropriate God-image in order to address, but also manipulate the needs of people. Again: no!

\section{Rhetorical camouflage?}

One could of course argue that the preacher merely strives to balance the first part of the sermon with the latter, to complement the indicative with the imperative (analogously to what Paul does in some of his letters). I do not believe that this is the case. The first part of the sermon rather serves to camouflage the last and indeed focal part, where the preacher now in fact does expect his listeners to elevate their faith to the "measure of those people of Biblical times", as already hinted at in the introduction of the sermon. ${ }^{112}$ These biblical characters become examples that the listener must copy, and as such become a law unto themselves. They become non-human beings, and are in fact held forth as legends, as people who "never' failed to put their trust in God ... 'never' gave up on God". ${ }^{113}$ Never? Really?

The description of Joshua gives fuel to the present-day homo intactus, 'enabling $\mathrm{him} / \mathrm{her}$ to be unshakeable. ${ }^{114}$ Joshua is pictured as anything but vulnerable, the perfect allegory for 'able' believers, for people who have a (tautological) "believing faith". He does everything right, never failing, never faltering. And the question following this, of course, is: "Do 'you' have such faith...?"115

\footnotetext{
109 The analogical schematism that is used in this sermon (i.e. between Israel and the South African nation) in fact dispels unilaterally the tension that characterises the dialectic relation between God and time. See the previous discussion. Cf. Cilliers (2006:20-23).

110 See the discussion in Chapter 2.

111 Cf. Josuttis (1966:20ff.). See the previous discussion in this chapter on 'cliché'.

112 Crossing the Jordan, par. 90-94; cf. par. 21.

113 Crossing the Jordan, par. 3 and 5.

114 Crossing the Jordan, par. 8.

115 Crossing the Jordan, par. 94.
} 
Jordan itself no longer stands as a 'symbol of God's faithfulness', but becomes a 'paradigm for manipulation', based on the presupposition that there is an undisputed 'link and identification, i.e. a situational analogy' between God's acts within the nation of Israel and the needs of various groups in South Africa in 1994. In fact, as I already indicated before, 'the use of such an analogous scheme is symptomatic of a search for security in a time of emergency.'116 The analogical use of the Jordan narrative serves to address the "uncertainty and fear"117 of South Africans during 1994.

But more importantly: the hinge on which this paradigm of manipulation turns is the imperative to act according to the unshakeable examples of Joshua and other biblical champions of faith. 'Jordan' becomes a pious, inner state of strength that we can derive through duplication of these champions of faith - 'then' we can face experiences like changing of jobs, buying new houses, entering marriage, etc. ${ }^{118}$ Then we are indeed 'able.' In the process, "The Ark of the Covenant of God", which "represents the actual presence of God", 119 becomes a symbol of power, of human enablement; God's presence is utilised for empowering and enabling. In short: The Ark becomes the elongation and ultimate legitimisation of a religious activist agenda.

In my opinion, the introductory passage of the sermon already harbours, and in fact prepares the listener for, this activist end. In the very first sentences of the sermon we hear: "The scriptures abound in examples of men and women who took God at his Word ... Can the same be said about you and me this morning?" ${ }^{20}$ This basic question, which forms part of the backbone of the sermon, is repeated later on: "Do you have such faith to believe that God will rescue you no matter what your situation?" 121 Rhetorical questions such as these are characteristic of classical religious activism. ${ }^{122}$ What answer does the preacher expect? Yes or no? Of course, we do not 'have' such faith! 'Must' we now generate it? 'Must' we now consecrate ourselves so 'most completely' that we are able "to see the Triune God" as the preacher implores us elsewhere? ${ }^{123}$ 'Must' we now be enabled to see a fixated (as opposed to a moving) God-image?

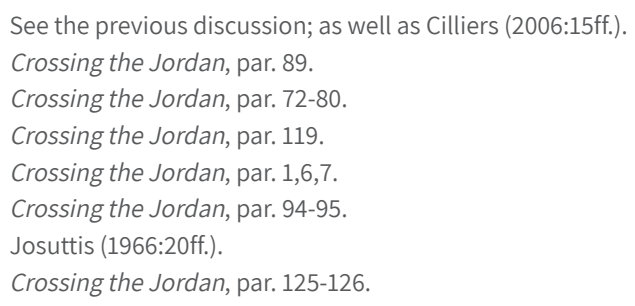


It is ironic and inevitable: in the very beginning of the sermon already lies its manipulative end. In the last paragraph we hear of 'God's invitation' which is still open, but this becomes subject to 'our invitation' of Jesus into our lives. ${ }^{124}$ The question is: 'who in fact invites whom?' It would seem as if the whole sermon is geared towards this end, as a type of 'altar call' to listeners over the radio: to admonish them to 'invite Jesus into your lives'.

God's miracle now only takes place "as I entrust myself to thee". ${ }^{125}$ The sphere in which the sermon operates remains the inner state of the religious listener; the hermeneutical space remains reduced to the pious inner circle of the homo religious and homo intactus. While some preachers sidestepped the 'now' by means of silence, and others endeavoured to fill up the void with religious activism and fixated God-images, this sermon represents a type of culmination of the latter, by trusting the homo religious and homo intactus to fulfil, i.e. give quality to the 'now.' ${ }^{126}$

In the process, the same pious material is used repeatedly, and ultimately, all sermons like these end up with 'an invitation to invite Jesus into your lives'. This stereotypical pious encircling of biblical texts bypasses the reality outside the circle, in this case the reality of a South Africa in a time of transition. The listeners finds themselves in uncertain times, but they are not called to make decisions and act 'within' this situation; they are rather 'taken out' of this to a pious sphere where they must (for how many times more?) make a decision for God and to 'invite Jesus into their lives.'

In a sense, the first part of the sermon is sabotaged by the second and especially third part. All the glowing indicatives of the first part (where the preacher speaks 'historically' about what God has done) are funnelled through, and coloured by, the God-image of the second part (where the preacher speaks about the 'future intent' of God), and ultimately by the 'imperatives' of the third part; for instance, God's choice to work amongst us becomes subordinated to our choice to invite Jesus into our lives; the fact that God works in God's own time is shackled by people's timing ${ }^{127}$ - 'when' you consecrate yourself to God, most completely. ${ }^{128}$ In fact, the four questions of the introduction - where, how, when and why God works ${ }^{129}$ - are all subjected to the way in which we 'must'

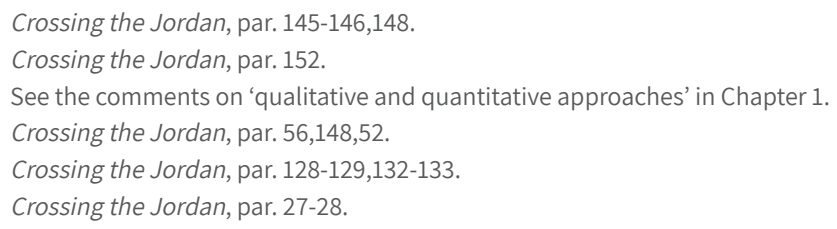


now cross our Jordan. God now indeed does work under "force or pressure", 130 namely that of the homo religious and homo intactus; God no longer is "in control", ${ }^{131}$ no longer holds the initiative, no longer acts as prima causa, no longer goes before us 'so that' we may follow, but rather follows us 'as we' go before God.

\section{Deus debilitatus?}

The sermon contains many ironies. The preacher speaks about the unchanging God and yet his sermon changes (disables) God; he intends to picture what God will be doing (futurum), but does not understand that God is (continuously and actively) coming into the present (adventus); he calls upon his listeners to understand that God works in God's own time, and that we are "often frustrated by what seems to be God's slowness in responding to our needs", even stressing that we have to wait like Moses and Joshua did, because "the same is of course true for you and me today,",132 and yet his religious activism does not allow him to wait. The God of the future (deus futurum) must be brought into the present through pious activities, instead of waiting for the revelation of the presence of the continuously coming God (deus adventus).

Perhaps the biggest irony of all is the fact that the preacher presents (pictures) the image of a disabled God in his sermon, not understanding that there is indeed another picture of the disabled God, a picture not created through the activism of the homo intactus, but through the revelation of God's 'incarnation and inhabitation. God's presence (the Ark of the Covenant in Joshua) is not 'a mighty power' that blows everything and everybody away. God does not side with the mighty. ${ }^{133}$ God's power (or ability) to dwell in is rather of a different order: it is that of a God crucified, resurrected and poured out on all flesh. Not within an able world, but within a disabled world, 'for the sake of this disabled world'. In the process, God is 'not' left intact, but is shattered; God is not whole, but fragmented; God is not able, but disabled and incapacitated (deus debilitatus). ${ }^{134}$

\footnotetext{
130 Cf. Crossing the Jordan, par. 48-49.

131 Cf. Crossing the Jordan, par. 106

132 Crossing the Jordan, par. 53-55.

133 One is reminded of various political parties in South Africa, who often claim that God is on the 'their side'. We are taken back to the questions that we posed at the beginning of this analysis, namely: did sermons like these help us in our time of transition? Did they launch us on a path of healing, or the contrary? Dare we say that sermons like these contributed towards picturing a God that can indeed be activated to 'be on our side'? A God that can be 'called in' to legitimise our search for power? And that ironically, through this, God is in fact incapacitated and 'taken out of picture' in post-apartheid South Africa? 
In a moving account, the theologian Nancy Eiesland, herself being a disabled person, speaks as follows of her epiphany concerning the image of God:

I had waited for a mighty revelation of God. But my epiphany bore little resemblance to the God I was expecting or the God of my dreams. I saw God in a sip-puff wheelchair, that is, the chair used mostly by quadriplegics enabling them to manoeuvre by blowing and sucking on a straw-like device. Not an omnipotent, self-sufficient God, but neither a pitiable, suffering servant. In this moment, I beheld God as a survivor, unpitying and forthright. ${ }^{135}$

Is this not a striking image of a God that moves in time, with us? In the present time, and presence, of our brokenness, this God is present, with a broken Presence. Preaching as timing of the present pre-senses this Presence ...

Perhaps it is wise to turn to an aesthetical expression of time, once again, to 'see' the profundity of this view on temporality, a bit better ...

\section{Trains to Life; Trains to Death}

Next to the Friedrichstraße railway station in Berlin, Germany, on the corner of Friedrichstraße and Georgenstraße, one finds a depiction of seven children, entitled, Trains to Life; Trains to Death. This moving sculpture by Frank Meisler was unveiled on 30 November 2008, and it depicts one of the many horrors of the Second World War: the deportation of children, either to life or to death. 


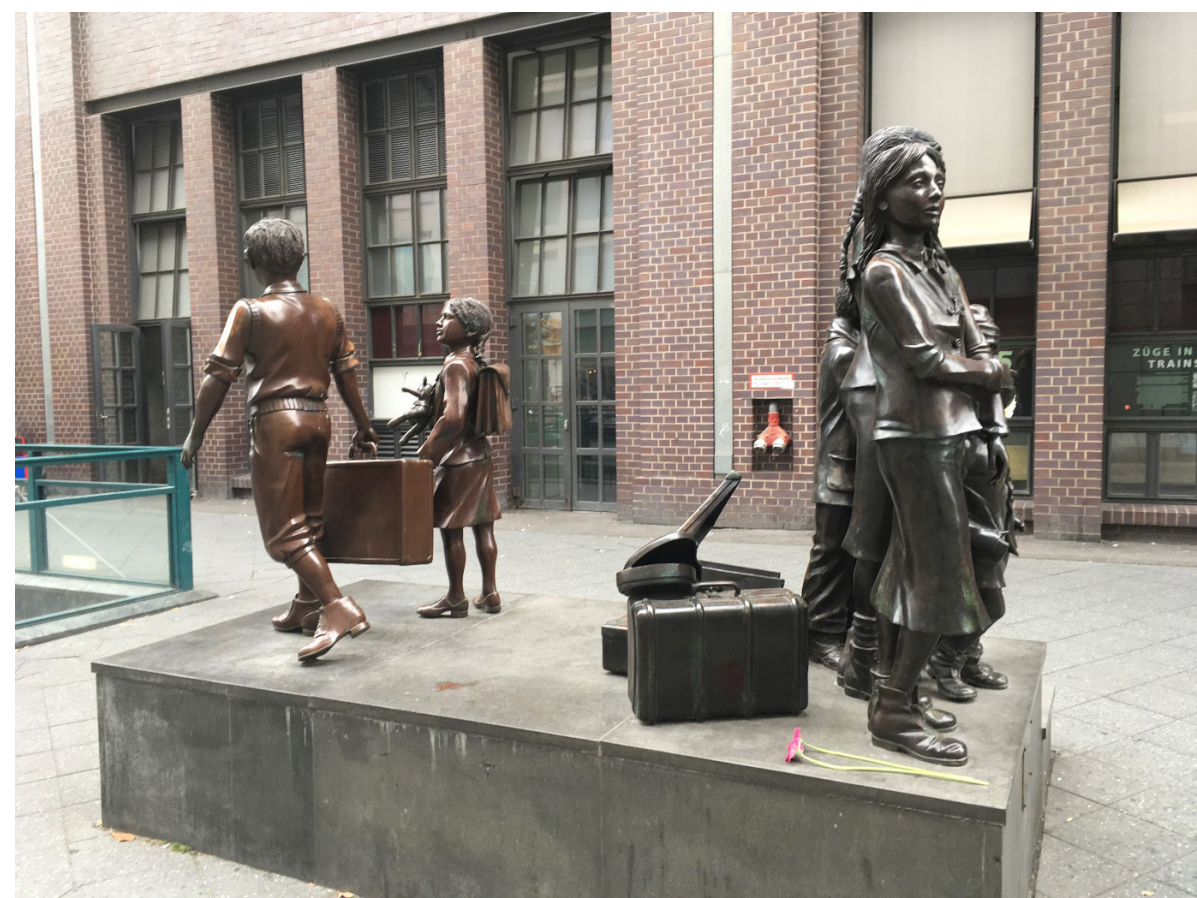

Figure 3.2 Frank Meisler's Trains to Life; Trains to Death (Photo @ J Johan Cilliers)

The memorial, standing at about 2,25 meters, is made of bronze, and it consists of seven children, boys and girls, almost life-size - five facing the reality of being loaded onto a train that will deport them to concentration camps, and two facing the other way, hoping to be put on a train to freedom, and life. The five children's body language says it all, speaks clearly about their plight, with broken musical instruments and a suitcase containing a broken doll at their feet. The colour of the bronze is darker than that of the two children, and these five children represent the estimated 1,6 million children murdered in the Holocaust. 


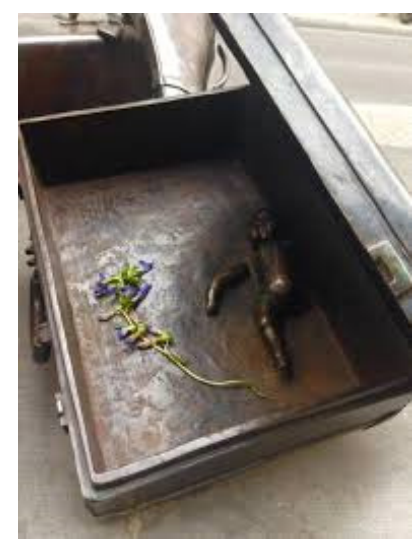

\section{Figure 3.3 Part of Frank Meisler's sculpting Trains to Life - Trains to Death (Meisler, 2008)}

The two children facing the other way, portrayed in lighter bronze, as if in sunlight, represent nearly 10,000 Jewish children from Nazi Germany, Austria, Czechoslovakia and the Free City of Danzig whose lives were saved by being granted entry into England in 1938, and being placed in British foster homes, hostels, and farms.

This space - the Friedrichstraße station - is the exact location where children were put on to trains, leaving for life; while those leaving for death were hoarded on board throughout Nazi Germany. ${ }^{136}$

This memorial contains several remarkable features. It exudes an 'aura of movement', a sense of expectation; representing the opening or closing of the doors of life. Each figure speaks volumes, expresses personal suffering, or liberation. It is particularly moving to know that the sculptor, Frank Meisler, was a traveller himself on a train in 1939 to England, being saved from death in a concentration camp.

But, equally fascinating, at least for me, is the fact that these children are looking in opposite directions, with an open space between them. The children facing the concentration camps are looking into the terrible past of the Second World War; the children facing new homes, look to the future. The whole sculpture embodies a sense of time ... and I would say, timing. But the

136 This memorial is one of four sculptures, which have been erected along the children's route to safety. The others by the same sculptor being 'Kindertransport - the departure' in Danzig, Poland; 'Kindertransport the arrival' at Liverpool Street Station in London; and 'Channel of life' at the Hook of Holland, Rotterdam. For a good overview, see the article by Hacker and Goodman (n.d.). 
space in between the figures, in between past and future, seems empty, seems to represent a present that is a vacuum.

This begs the question: how was it made possible for at least some children to be moved from a past of death, to a future of life? What happened in that seemingly empty present? Obviously, that present was not empty, does not represent a vacuum. On the contrary, at least historically speaking, it was filled with acts of liberation, with initiatives of grace.' The name of the trains that carried the children to life was called Kindertransport, given by people who initiated this rescue mission that began nine months prior to the outbreak of the Second World War. The mission's intent was to transport children to safety - children who could not speak, or act out, for themselves. The first train left Berlin's Friedrichstraße station with 196 children on board on 30 November 1938.

And of course, these 'people' who initiated this rescue mission, had names and faces. It was London stockbroker Nicholas Winton, moved by the fate of Jewish refugees, who worked with his fellow Britons to bring the first rescued children to the United Kingdom.

This present, between this past and future, was 'not' empty, but filled with empathy, with grace. In a sense, it is filled up in a special way by the sculptor himself - as one who knew first-hand what this movement from past to future entailed. In a sense, his own empathetic presence, his own broken, but liberated body kneels there...

I reiterate what I said earlier: in preaching, past and future condense into present, as Presence. Preaching is about the pre-sencing of this Presence. ${ }^{137}$ But again: what past, and what future, and what present/Presence are we talking about?

\section{Past ...}

The past is obviously, inter alia, about remembrance. Remembrance in fact forms a characteristic part of all religions; religion has always had a memorial aspect. ${ }^{138}$ The Christian religion could also rightly be called a religion of remembrance. In fact, the root word for remembrance (anamnesis; the mnē

137 See the previous discussions in Chapters 1 and 2.

138 Landres and Stier (2006:1). 
group) covers a concept, which is fundamental to the Bible and encompasses the whole of divine and human life. ${ }^{139}$

The biblical concept of anamnesis is deeply rooted in a specific understanding of the way in which time unfolds itself, or rather: is unfolded by God. Bartels contends:

God's revelation, unlike the nature religions, does not follow the birth-and-death cycles of nature; it is no automatically unfolding process as in the mystery religions or in Gnosticism. Rather, it occurs within the course of history ... stretching from yesterday, through today, and on to the future ... Hence, all the church's worship is and always has been historical, verbal and personal, rather than nature-orientated, mystical or dramatic. This is true of the preaching of the word, which aims to give outward expression to something which has happened in the past, by removing it from the wrappings of memory or of oral or written tradition and so recalling it to men's minds. ${ }^{140}$

In this act of remembrance, however, we should not fall prey to a 'homiletical over-estimation' of the past, or of the notion of linear time, for that matter, as we stated earlier. ${ }^{141}$ This over-estimation can take on many forms, often manifesting itself within preaching by, for instance, repristinating (the urge to repeat in the exact form, as in 'history is repeating itself'), traditionalism, fundamentalism and a mythical solidifying of time - all of which could be called a 'monumentalization' of time. ${ }^{142}$ Then the past becomes a 'pocket' that should be neatly brought into the present, to be erected there as norma normans for all further action, present and future: 'As Abraham did, we should also ...'

But the past is indeed the 'past'. It lies behind us and cannot be repeated. History does not repeat itself - contrary to what the popular slogan says. Gertrude Stein, the famous American writer and poet, once said: a rose is a rose is a rose, meaning (in terms of aesthetics) a rose is self-referential; its meaning is not constituted by realities outside of it, but much more by means of its modality, i.e. its relationship to these realities. ${ }^{143}$ Perhaps we could say, in the same vein: the past is the past is the past. It has gone by - and should be viewed as such. It cannot, and should not, be resuscitated homiletically.

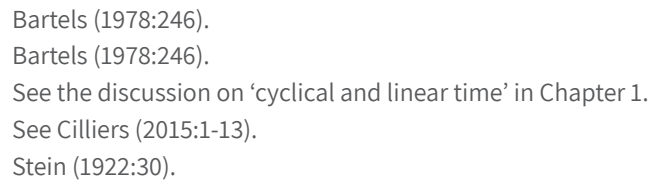


But in remembrance we should also steer clear of a 'homiletical underestimation' of the past, set within the framework of linear time. The past is of the utmost significance for the present. Therefore we could probably also, paradoxically, say: 'The past is not dead, it is not even past; the past is not dead ... it is not even sleeping.' ${ }^{144}$ The reason why people are interested in the past should, nonetheless, not be for the sake of a nostalgic or romanticised yearning for 'the good old days', in search for a type of retrotopia. ${ }^{145}$

Tradition as such, and the use of (homiletical) tradition, is no evil thing. Tradition should in fact serve as a conduit for meaningful transference (tradere) of culture from the past to the present, and to the future. We are not the first to invent the (homiletical) wheel. Others have come before us and it is wise to listen to them. In this sense, we need to 'celebrate the past', or rather: celebrate the acts of God in the past.

But we also have enough reason to lament the past. For this we need a 'responsible, hermeneutical dialogue' with the past, as we so often tend to apply a reduced form of remembrance, a selective memory, if not total amnesia. Ricoeur has written extensively on both the vulnerability and weakness of our acts of memory, but also indicates the potential of memory to interpret the past in a hermeneutically responsible manner. Memory is all that we have to link us to the past. ${ }^{146}$ But memory can also be abused in a variety of ways, for instance, on a pathological and therapeutic level, on a practical level (especially in terms of finding and defending our identity), and on an ethical-political level. ${ }^{147}$ We can simply 'remember' in search, and in aid of, power ...

We do indeed need an acute homiletical memory, as we so often tend to block out our wrongdoings of the past and find no need to lament them in the present. In this sense, the past is often strangely absent from our homiletics and indeed sermons. We seem not to understand that our wrongdoings of the past, especially those with grave social consequences, are not issues that can be settled and 'buried in the past' with a number of official denominational declarations, but which must be worked through in continuous discussions in a

\footnotetext{
144 Quotes from William Faulkner and David Lowenthal, in Vosloo (Charbonnier et al. 2018:215-226). Vosloo refers to five aspects of this search for a responsible engagement with the past, namely: The vulnerability of memory, the reality of the historical past, interwoven memories, subversive memory, and future-oriented memory. 
process of questioning and listening, and especially of liturgical and homiletical remembrance and reflection, instead of forgetting and pushing aside. ${ }^{148}$

We cannot run away from the shadows of our past - or sidestep it with silence. ${ }^{149}$ The sculptor Karol Broniatowski reminds us of this, by means of his haunting artwork, situated next to the infamous Track 17 at the Grunewald station (Western outskirts of Berlin), which functioned as one of the three main stations from where 55,000 Berlin Jews were deported during the Second World War. These people were mostly transported to Theresienstadt (a type of way station), or directly to the extermination camps.

The artwork, revealed on 18 October 1991, consists of a concrete wall with hollowed out imprints of human bodies. Seen at certain angles, it is almost not distinguishable from other, similar concrete walls; but when viewed from other angles, the sunlight creates shadows in the hollowed-out sections of the wall, resembling people walking towards the point of deportation. These shadows are fleeting - sometimes sharply edged, often vague, coming and going with the movements of sunlight, resembling the transience of life, and the vulnerability of the deported. During night-time, the images - of adults and children - are even more haunting, flickering and moving in the glow of nearby streetlamps, and other passing sources of light. 


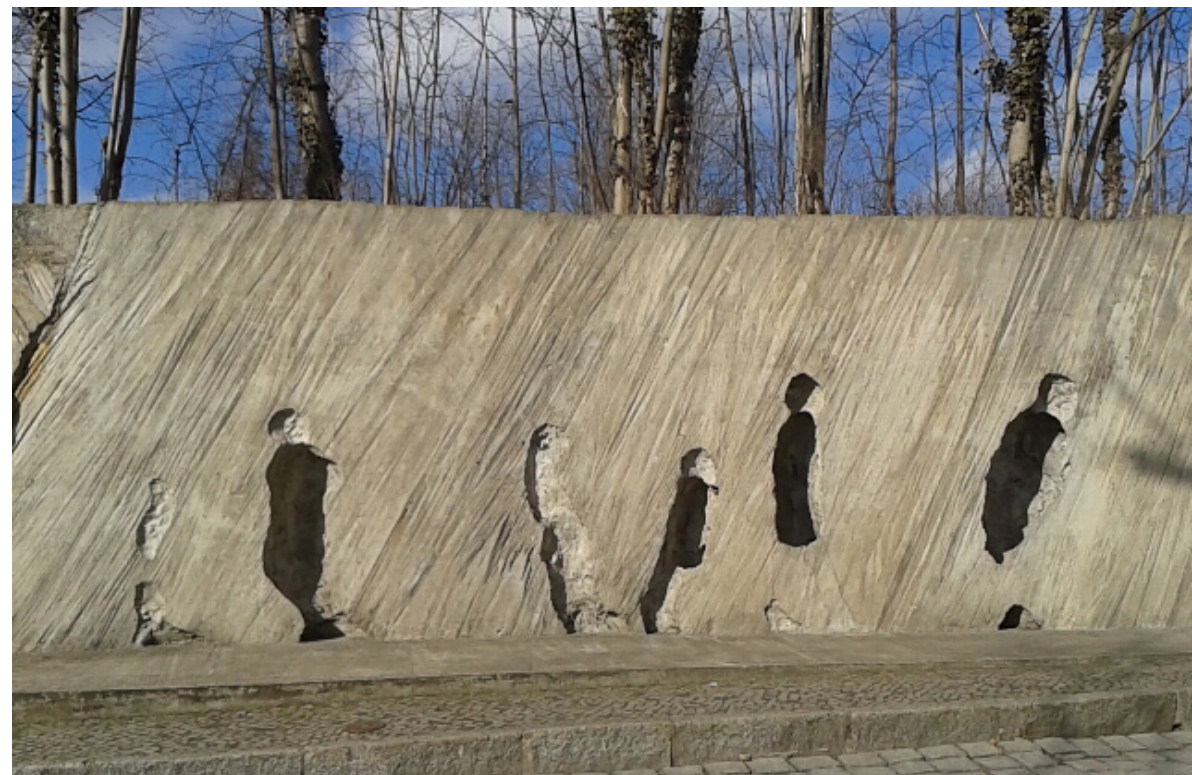

Figure 3.4 Memorial by Karol Broniatowski, revealed on 18 October 1991: bronze plaque and concrete wall with hollowed out imprints of human bodies (Fotoeins Fotografie, 2016)

Exactly 183 steel plates were placed on the platform, situated next to this artwork - each one representing one of the deportation trains that left this station, with Jews that were destined for extermination. Each of these plates shows the date, destination and the number of deportees. According to the available records, the last deportation train departed from this platform on March 27, 1945.

No train will ever again depart from Track 17.

But the haunting images remain ...

The act of remembrance (anamnesis), also of the haunting shadows from our past, is indeed of paramount importance for the act of preaching. 'What' we remember, but also 'how' we remember, determines not only our experiences in the present, but also our hope for the future. 'How' we face our shadows, from which (whom) we cannot escape, determines the amount of light, or darkness, filling up our present, as well as our future.

The act of remembrance surpasses and condenses time and space. The past becomes present and simultaneously a component of the future. In this 
sense, we 'remember' a future for ourselves that exists in hope. In the present (or, moment of preaching) we think, tell and act in reverse (remember) towards the future.

Many sermons, however, tend to suffer from amnesia. ${ }^{150}$ Their preachers have forgotten about Christ, or simply call Him into 'remembrance' in a mechanical and traditionalistic way, without understanding the deeper meaning of the Christ-event. They quote Christological formulae to escape from the real impact of the remembered, present Christ, as embodied through the Spirit. In the process, they fall prey to ideologies of power, which Keshgegian describes as kyriarchy ('which means the multiple and complex systemic grading of dominations, subordinations, and power arrangements'). ${ }^{151}$

To remember Christ as Kurios, however, is totally different from performing kyriarchy. To remember Christ as Kurios is to participate in a dangerous and subversive act, as this form of remembrance continuously interrupts and transforms us, takes us out of our comfortable liturgical and homiletical formulae, monumentalised theological structures and ideologies of power. ${ }^{152}$ It confronts us in a radical manner, but in doing so, also inspires us with hope for a new future that fundamentally colours our present. Remembering the Christ of the past in hope of the future recreates (reframes) the present. ${ }^{153}$

It also reshapes and reframes our identity, or again in the words of Keshgegian:

The act of remembering is constitutive of identity and the content of the memories shapes the character of the identity. The church not only needs to remember, but what and how it remembers will affect its nature and mission. The church's defining memory is the narrative of who we are in relationship to God in Jesus Christ. Christian identity is shaped in relation to that narrative. ${ }^{154}$

Indeed, we are in dire need of a critical and hermeneutical interrogation of the past. ${ }^{155}$ The potential of being homiletically enriched by this interrogation is

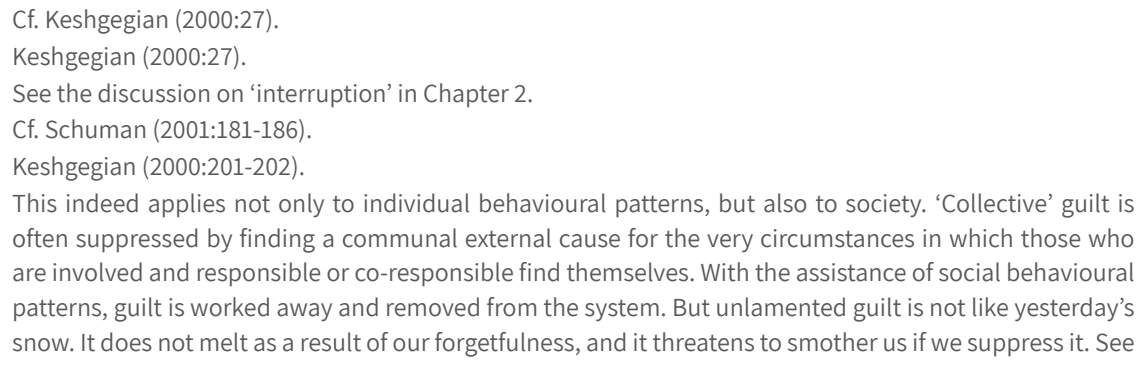
are involved and responsible or co-responsible find themselves. With the assistance of social behavioural patterns, guilt is worked away and removed from the system. But unlamented guilt is not like yesterday's snow. It does not melt as a result of our forgetfulness, and it threatens to smother us if we suppress it. See 
endless. It offers 'a horizon of expectation that opens the possibility of being strangely surprised by the past.'.156

But, being surprised by the past implies also being surprised by the future.

\section{Future ...}

Preaching is about remembrance of the past, but it is also about (anticipation of) the future. We are called to retell the message of Christ's death 'until He comes again. ${ }^{157}$ Obviously the future by implication means 'not now' - the future is the future is the future - but this is often misunderstood as an experience of time exclusively related to a futurum, i.e. an attitude or mentality that somehow bypasses the present in its eagerness for the future.

In the New Testament sense of the word, advent indicates a close connection between the saving presence of Christ 'who has already come' and the future. The hour that is coming, already is now. ${ }^{158}$ Anticipation is more about adventus (the coming of the present One), than it is about futurum. According to Jürgen Moltmann, the 'future' should be understood more in terms of the ways God is with us. This future of God's glory is not something that will be added on to eternity, for the sake of completeness. Between the faith in 'God above us' and 'God in us', comes a third possibility: 'God ahead of us', i.e. the 'God of hope and of the Exodus'. In the tension between our experiences of God's absence and God's presence, we are seeking God's future ... but this future is not something or a condition an eternity away; rather a power working in the present, through promise and hope, and in the liberation and creation of new possibilities. As the Power of the future, God works in the present. ${ }^{159}$

This understanding of the future as adventus clearly has profound implications for preaching. The present (presence of Christ) is celebrated precisely because the future is already here. It prevents us from practising a type of homiletical escapism, or our hope becoming apocalyptic. Anticipation is not about waiting for certain (apocalyptic) events, but about 'participation in the future'. Preaching could indeed be called an 'anticipatory participation in the presence of the coming One'. In the light of this understanding of adventus, it could be a fair question to ask whether 'the future is also not strangely absent from our

Bohren (Richter-Böhne 1989).

156 Vosloo (2007:290).

1571 Corinthians 11:26.

158 Cf. John 4:23; 5:25; and Mundle (1975:324).

159 Paraphrased from Moltmann (1975:177-178). 
sermons. Often the future is treated as a distant and totally unknown phase of time, rather than celebrated as gift that 'already' fills the present with meaning.

The latter point does not negate the fact that we have 'not yet' reached the telos of time. On the contrary, the homiletical and liturgical act of lament, for instance, does not only take place in the light of evil because it is simply there, but because the tension between what is (the 'presence of the future') and the discrepancies and paradoxes called forth by evil cry out for a 'final' answer and solution (i.e. the 'future of the presence'). ${ }^{160}$ This interconnectedness between the presence of the future and the future of the presence constitutes one of the most basic tensions in preaching, in particular in terms of timing. ${ }^{161}$

\section{And present ...}

Preaching is not just about 'anticipation', but also 'incarnation' and 'inhabitation' - 'in the present'. The Christian religion is not only a religion of remembrance, or anticipation - it is also acutely aware of (the importance of) the present, of the here (space) and now (time). ${ }^{162}$

This 'here and now' could be misunderstood in several ways. It could, for instance, be equated to certain forms of mysticism. The latter endeavour to extinguish both time and space, to find an eternal now. ${ }^{163}$ The effect of this form of mysticism is that time cannot create a radically new creation and no novum can be formed - there can be no escape from the tragedy of a cyclical

160 This tension between the future that is already with us, and simultaneously not yet, finds its best expression in the Eucharist. Purcell (2001:142-143) elaborates: "The present celebration of the Eucharist is referred to a past which exercises a certain judgment over the present and summons the present celebration to be responsible and faithful celebration. But, so too with the future orientation of the Eucharist. The life, death and resurrection of Christ which establishes the new covenant inaugurates the kingdom of God, and thus provides a substantial anchor for that 'pledge of future glory' (pignus futurae gloriae). The future is not an empty promise; it has already been established ... It already has a content which has been realised in the life, death and resurrection of Christ ... Thus, as with the past, the future has a certain exteriority regarding the present. It is that which, along with the past, gives a present."

161 See the discussion on 'Allan Boesak's sermon' in Chapter 4.

162 "Behold, 'now' is the acceptable time; behold, 'now' is the day of salvation" (2 Corinthians 6:2). When Christ breaks the bread during the last supper, He says: "Do this in 'remembrance' of Me", but He also says: "This is my body which is given for you" (Luke 22:19). He is not making a general remark, fitting for all times, but an offer, hic et nunc (here and now).

163 “... Über aller zeitlichen Gegenwart stehende ewige Gegenwart." Tillich (1962:191). See the discussions in Chapters 1 and 7 . 
birth and death. ${ }^{164}$ As we said earlier, this contradicts the notion of a moving God that moves in time, and moves time. ${ }^{165}$

The 'here and now' could also be misunderstood as a form of mythology. Destructive myths always tend to 'change history (or: time) into nature. ${ }^{166}$ Time is arrested and fixed in space. What is contingent is solidified as stringency. This is done to sanctify certain motives and ideals, often nationalistic in nature. But, in the end, (linear) time always draws its line through the circle of exclusivist space and congealed time; always reveals the inherent transience and finitude of any destructive myth, however powerful it may also seem to be. ${ }^{167}$

We indeed need phronesis to discern the value of the present. In the New Testament sense phronesis means a type of mentality that undergirds the inter-relationship between life and thought: "It expresses not merely an activity of the intellect, but also a movement of the will; it is both interest and decision at the same time ... this attitude of mind is closely connected with spiritual status: the believer's new standing in Christ both creates and demands a new mentality ..." ${ }^{168}$ This new mentality or attitude is one of looking at life, and the realities of the present in particular, through the lenses of the Christ-event; it is to discern the deeper meaning of the present moment - as a moment being filled by Christ Himself. ${ }^{169}$ It is indeed, in terms of this book, about timing as pre-sencing the Presence of Christ in the present. ${ }^{170}$

The present is filled with the past and the future. But we cannot live in the past or the future. We live in the present. It should not be devalued in any way. The present is the present is the present. It is a gift to be experienced, to the full, because it brings with it the presence of the One whom we celebrate. ${ }^{171}$

164 "So verstanden ist die Mystik die subtilste Form der Übermacht des Raumes. In subtilster Form verneint sie die Geschichte, aber durch die Ablehnung der Geschichte verneint sie zugleich denn Sinn von Zeit." Tillich (1962:192).

165 See the previous discussion in this chapter and footnote 6 in Chapter 1.

166 Barthes (1964:113).

167 Tillich (1962:190-191).

168 Goetzmann (1976:617,619).

169 In preaching we proclaim the God of history, the God of Abraham, Isaac and Jacob, of Sarah, Rebecca, and Hagar, that is, the God of the past (cf. Exodus 3: 6), but therefore also the God of the present and the future. When God says to Moses: "I am who I am" (Exodus 3:14), God fills the present with pregnant time (Kairos). It is the same One who says: "I am", and also "I was what I was", i.e. the God of Abraham, Isaac, and Jacob, of Sarah, Rebecca, and Hagar. But at the same time God is also the God who fills the future with God's promises, when God declares: "I will lead you out of Egypt," (Exodus 3:17); the same God who implies: "I shall be what I shall be."

170 See the discussion in Chapter 1.

171 In preaching, time is pressed into the present, as 'Ballungen von Zeit. Jüngel (1974:116). Or as Friedland and Hecht put it: "Central places, holy places, sacred places, memory places are those in which time is 
We celebrate the fact that that what was and will be, 'already' is. In contrast to this, we could so dwell on the past, or so escape towards the future, that the ontological gift of Christ's presence in the present is overlooked. It could also be that the present (presence) is strangely absent from our sermons - as we have seen in many of the sermon analyses above.

Certain forms of mysticism and mythological understandings of time may seem to be deep, but in fact they represent time being made 'superficial' of time, exactly because they try to escape from time. When we speak about discernment of (Christ's) Presence in the present, the latter is in no way intended. Homiletical discernment of Presence in the present is not a form of mystical escapism or mythological annihilation of time but should rather be understood as 'time out.'

The latter phrase is often used in the world of sport. For the game to be continued, 'time out' is taken to remind players of rules, to tend to those injured, etc. Time as such, of course, does not stop for one second, but the stopwatch for 'time out' signifies a different time zone, or time experience. 'Time out' exists within time, but simultaneously outside of time. It does not stop, or negate 'normal' time, but is there exactly to enhance the play taking place in 'normal' time. 'Time out' entails reframing, perhaps rescheduling, and re-evaluation of normal time. In preaching, we take some 'time out', or rather: we are given the gift of 'time out', not as an escape from time, but rather so that we can re-enter time, and experience 'time in' in a different manner. 'Time out' does not represent 'fairyland time', but real time - to reflect on (the meaning of) time. ${ }^{173}$

This 'different experience of time' could be called a type of 'condensation of the times': the past is presented in such a way that a yearning for the future is created, but a future that continuously breaks through into the present. The present then represents a form of 'punctual coincidence': the past and the future coincide in such a way in the present that the present becomes an epiphany, a point of revelation. ${ }^{174}$

concentrated, thickened. They are places where the beginning of time presses into the present and the present bleeds into the end of time. Beginning and end are there, but central places, holy places, sacred places, and memory places are intensely present." Friedland and Hecht (Stier en Landres 2006:17-35).

172 See Cilliers (2009:26-35).

173 See the discussion on 'fairyland time' in Chapter 1.

174 In this regard, Purcell refers to the phenomenon of 'Eucharistic Time', which signifies 'the presence of Transcendence'. The Eucharist is not only a present event; it rather creates the present as present. It constitutes the present as a gift (present). It interprets the present time in order to make it the time of the present/gift, or expressed in the above terms, it calls for 'time out', to transform 'time in' into a 'Kairos'. 
It is clear that 'now' is a relative and multi-layered notion. If we say, for instance, that 'so-and-so is President of the United States of America now', we have a four-year term of office in mind. Every 'now' is composed of many other 'nows'. The starlight we see 'now' is a 'now' of millions of years in the 'past'. The 'now' of hearing thunder comes seconds after the 'now' of the lightning - and so on. 'Now' indeed has many moments and is more than just a fleeting point on a line of fleeting points. ${ }^{175}$

Perhaps CS Lewis was right when he said: “... the Present is the point at which time touches eternity."176 $\mathrm{He}$ asks the fascinating question how much time God has to answer our calls for help, and answers as follows: "Almost certainly God is not in time. His life does not consist of moments one following another ... Ten-thirty - and every other moment from the beginning of the world - is always Present for Him. If you like to put it this way, He has all eternity in which to listen to the split second of prayer put up by a pilot as his plane crashes in flames."177

Perhaps prayer indeed is the most intensified form of timed, and timing, grace.

Time to sum up: the homiletical acts mentioned above (remembrance, anticipation, discernment) could be described as human expressions of faith (religious existentialia) and form the contours of preaching that is sensitive as to its dimensions of temporality. They could also be understood as divine acts. We remember on the grounds of God's remembrance of us; we discern because it is a gift of Christ's presence; we anticipate because the present One is (in) coming. God's acts in time (past, present, future) dovetail with our homiletical acts in the light of time. ${ }^{178}$ 'Timing grace' is indeed a reciprocal event: preachers time grace; and grace times preachers.

Purcell quotes, and in the process slightly alters, Aquinas' doxological understanding of the Eucharist: "O Sacred Banquet in which Christ is our food: the memory of his passion is recalled, a pledge of future glory is given", and “... (so) our lives are filled with grace”. According to Purcell, the 'and' in the previous sentence does not simply signify a conjunction that connects the present with the past and the future, but it is also a concluding 'so/therefore'. The gift of the Eucharist, "... arises in a past covenant; it points to an eschatological future charged with hope and promise; and because of this, it establishes a present". Purcell (2001:141-144). This filling of the present, or constitution of the present through the gift/present of the Eucharist (presence of Christ), could be called 'infinituding'. Time is filled with the infinitude; it becomes infinite. Cf. Van Wengen-Shute (2003:101, 98-107); and Wainwright (1983:131).

175 See Wilson (2008:41).

176 Lewis (2001a:75).

177 Lewis (2001b:166ff.).

178 What Bartels (1978:246) concludes in terms of remembrance is true for discernment and anticipation: "God's 'remembrance' of his people ... dovetails with his people's 'remembrance' of Him in praise and testimony ... God's remembering is thus an efficacious and creative event." 


\section{SERMON: GOD REMEMBERS ... TO FORGET}

God heard their groaning, and remembered God's covenant ...

Exodus 2:23-25

In his work entitled, Traveller without baggage, the playwright Anouilh tells this eloquent story: during the war, a young soldier is struck by a bullet in the head and loses his memory. He cannot remember his name, does not know who his parents are or where his hometown is - he becomes a person without identity, without a history. The past, for him, is nothing but a haunting haze ...

After the war, an attempt is made to track down his kin through the press and radio. A few families enquire, and arrangements are made for the young man to travel from family to family, in the hope that there will be recognition or memory. Thus, the young man without a past, without the baggage of yesterday, travels on - only to have to continue his way disappointed every time. Until one day, he walks into a house and the whole family cry out as one: "That is our son! Our brother!" But the recognition is not mutual. He stares at them uncomprehendingly, stands there as a stranger amongst strangers ...

The family confronts him with painful experiences from his youth to shock him into remembering. They take him to a dangerous spiral staircase from which he pushed a young friend in a fit of temper, breaking his neck and limbs. He shakes his head: "I cannot remember ..." The servant girl takes him aside and asks him, with tears in her eyes, if he has forgotten the grief, he caused her. $\mathrm{He}$ shakes his head: "I cannot remember ..." And so, it continues, with no success.

Then somebody remembers a birthmark on his body, something only his family would know of. The minute he sees the birthmark in the mirror, his memory returns instantaneously. And he remembers: 'I was no angel.' His past, with all its sin and guilt, looms before him so grotesquely that it threatens to overwhelm him. So, he decides to pretend, to not admit that he has regained his memory. Against his family's wishes, he continues his journey the next day. 
The next family he meets need a male heir. They reach an agreement: he will pretend to be their son, and they will pretend to be his parents. He does this, not for the sake of the inheritance, but to make a new beginning, to turn over a new leaf, as it were to leave his guilt-ridden history with his true family behind him - like a forgotten suitcase on a deserted platform. (A traveller [seemingly] without baggage, but [in reality] burdened with baggage.)

This young man is also our brother, our family. His story is also our story. When it comes to our sinful pasts, we often suffer memory loss, or at least selective memory loss. Consciously or unconsciously, we conceal our guilt, try to justify it, dismiss it, or rationalise it. We are masters of the art of presenting our sins as virtues. We often take what is beautiful in the past, and build our future on it, but that, which is less beautiful, we sweep under the rug of oblivion. Our clean conscience (and consequently good night's sleep) is often nothing else but a poor memory.

Until our past catches up with us, our history overwhelms us from behind. Because in the long run we cannot outdistance our past. Despite all our manoeuvres we cannot make a new beginning, we cannot turn over a new leaf, we cannot wiggle ourselves out of the suitcases of our past, heavily laden with the ballast of our guilt. In a certain sense, our past forms our identity, and it clings to us until one day we cry out: "What a wretched person I am! Who will rescue me from this coffin that I have to drag with me?"179

Fortunately, God is not forgetful, does not suffer from memory loss or selective memory loss. God recalls our sins, sees our transgressions, brings to light the misdeeds we try to hide. ${ }^{180}$ God is not fooled by our pretence. God remembers. But sin is not all that God remembers. God looks further back, beyond our sinful past, to the compassionate history God created - especially remembering 'that'.

As in the case of Israel in Egypt, the place of slavery. Why were the Israelites there? There could be only one reasonable answer - through their own actions. Their disobedience and rebelliousness towards God landed them in this situation. Their own sinful past caught up with them to the extent that the present became unbearable, the future without prospects. In their misery, they

\footnotetext{
179 Cf. Romans 7:24.

180 Cf. Psalm 90:8.
} 
sighed under their heavy burden. But their groans and cries for help also went up to God. ${ }^{181}$

And ... God remembered! What? Their saddening transgressions, yes, but more: 'God heard their groaning and God remembered his covenant with Abraham, with Isaac and with Jacob. So, God looked on the Israelites and was concerned about them.'182

God thinks of this covenant. God recalls God's mercy. This godly self-remembrance is a key moment, which keeps on repeating throughout the Bible. It is here, in God's good memory, that salvation is born. We forget so easily, but God remembers. God considers His's covenant of mercy, and compassion - to empower and reactivate it again. God 'remembers to forget' our sins; remembers the history He made with us, in order to grant us a new future.

Only God can do this. Only God can take our sinful pasts upon Himself, carry our heavily laden baggage, so that we can be freed of it, can walk towards a new horizon. Our self-remembrance is often nothing else but clever self-delusion; God's self-remembrance, on the contrary, institutes salvation, is the mother of all hope. It is a step back into history, and at the same time, a step forwards into the future. It is self-reminding of the salvation history, which includes the hope for the future.

Just as it was with Israel. God's self-remembrance precedes God's revelation to Moses. ${ }^{183}$ The entire unfolding of the Exodus story flows from this, as it acted as the fruit of God's reflection on what was. The exodus out of Egypt, the journey through the desert, the arrival at the Promised Land - are all born from 'God's self-remembrance'. It has nothing to do with the piety of Israel, and everything to do with God's grace.

Let us now try to remember not to forget what happened on Golgotha, where, more than anywhere else, we see God's self-remembrance in action. God thinks of our sins. God allows the full force of our baggage to come down on Jesus. On Golgotha Jesus bows and breaks under the weight of our coffins. Our haunting history catches up with him.

But it is exactly here that God also remembers the covenant with Abraham, Isaac and Jacob. Especially here God takes our history upon Himself, so that

\footnotetext{
181 Cf. Exodus 2:23.

182 Cf. Exodus 2:24-25.

183 Cf. Exodus 3.
} 
we may be gifted with a new future. From here, from this deserted platform of godforsakenness, we can continue our journey, as travellers without baggage, but also as travellers with a future. We become part of a (real) family. We are taken from the train en route to Death and put onto the train to Life.

God applies self-remembrance. The miracle is that: 'From time to time God allows us to remind Him to remember not to forget.' Indeed, God 'can' be reminded of God's grace, and reminds Himself of this grace ...

For those standing before the mirror and in a disillusioning moment are confronted with the full truth of his or her sinful past, there is no better prayer than this:

Lord,

Do not think on my sins.

Do not call my injustices into remembrance.

Rather remember your compassion and mercy, your patience and great love. ${ }^{184}$ Lord, please remember ... to forget. 


\section{Chapter 4}

\section{INTERRUPTING TIME}

Up until this point, we have been taking cognisance of sermons that somehow mistimed grace, against the background of the eras of apartheid and post-apartheid - the times we lived and live in. Of course, there were also other preachers that seemed to understand the art of timing grace, during the same times as referred to above. Their sermons could be described as 'modes of interrupting time.' ${ }^{1}$ In what follows, a selection of sermons from three of South Africa's best-known 'prophets' against, i.e. interrupters of, apartheid will be re-heard - those of Allan Boesak, Desmond Tutu, and Beyers Naudé.

All these preachers brought a distinctive style of preaching to the struggle against apartheid. In my opinion, the different styles of these three preachers could in itself make for interesting discussion, and could be broadly described as follows (although these distinctions are obviously not watertight; rather with elements thereof being present in the sermons of all three): Allan Boesak preached in a rhetorically masterful and often confrontational manner, moving masses and unmasking the powers of the day. ${ }^{2}$ Tutu, doing the same, added the inimitable dimension of holy wit, often revealing the insanity of the political structures by means of lampooning, in effect unmasking the status quo by means of the folly of the Gospel. ${ }^{3}$ Beyers Naudé contributed to all of this in his unique way, by logically spelling out the consequences of certain actions, within the framework of a specific understanding of ethical responsibilities.

It would indeed be an interesting exercise to plot the styles of these three South African preachers against the distinctions made by someone like James Gustafson concerning the variety of moral discourses that are possible. ${ }^{4}$ Gustafson refers, among other things, to a 'moral discourse of indictment' that

See the discussion on timing as interruption in Chapter 1.

"Allan Boesak has always been keenly interested in power... This certainly explains many of his own choices and commitments, his own involvement in many struggles and his own outspoken positions on many issues." Cf. Smit (2014:11).

3 When Dr Piet Koornhof declared boldly during a visit abroad that 'apartheid is dead', Tutu retorted, "Apartheid, we were told by Dr Koornhof, is dead. Sadly, we have not been invited to the funeral, nor have we seen the corpse." Campbell and Cilliers (2012:196).

4 Cf. Gustafson (1988:269ff.). 
confronts and reveals the roots and effects of moral injustices in society - much like Allan Boesak did and is still doing, speaking in such a manner that a sense of urgency, even crises is evoked. A second mode that Gustafson refers to is the so-called 'utopian mode of moral discourse', using language that not only reveals the defects of the status quo, but creates pictures of a hopeful vision, of a better future - like Desmond Tutu did time and again, even in the darkest hours of apartheid, by speaking of a new South Africa where we all, 'white and black together,' will be living in justice. ${ }^{5}$

Gustafson also refers to the 'ethical or technical mode of moral discourse', in which precise distinctions and logic, also in explaining the consequences of core concepts like justice and the articulation of the rational grounds for ethical values shared by believers and non-believers, are typical features. Openness for dialogue is a fundamental characteristic of this mode of moral discourse. ${ }^{6}$ In my opinion, this could in fact be an indication of Beyers Naudés preaching style.

Let us first re-hear the voice of Allan Boesak.

\section{Allan Boesak: a moral discourse of indictment}

Allan Boesak can be described as one of the most gifted preachers that South Africa has ever produced - rhetorically, theologically, and especially prophetically. ${ }^{7}$ His preaching could be understood in terms of the distinctions that Gustafson proposed, as referred to above, with Boesak exemplifying a 'moral discourse of indictment' that confronts and reveals the roots and effects of moral injustices in society, speaking in such a manner that a sense of urgency, even crises is evoked. ${ }^{8}$

It has been said that 'Allan Boesak belongs in the company of the great preachers of the Christian church, who have found in Jesus of Nazareth the authentic voice of Moses and the Prophets, and in Paul of Tarsus and John of Patmos formative hearers and doers of that voice. Boesak's is a contemporary voice, joining in a single chorus of affirmation that 'the Word of God is that which strikes the conscience!"9

\section{Cf. Tutu (1983:15ff.).}

Gustafson (1988:269ff). . Gustafson also refers to the modes of prophetic, narrative, and policy moral discourses.

Cf. Tisdale (2010:92). Tisdale refers to people like Allan Boesak, Nelson Mandela, Desmond Tutu, Martin Luther King Jr, and others as people who put their lives on the line for what they believed in. What follows, is a revised edition of Cilliers (2013:1-15).

See the previous discussion.

Lehmann (1979). 
In what follows, we endeavour to re-hear this 'authentic ... contemporary voice', through listening to one of Boesak's own sermons. ${ }^{10}$ Boesak's sermons can indeed be described as 'prophetical', or, in his own words, as 'situational." His brief definition of preaching states: "Preaching is the proclamation of the gospel in a language that can be understood by persons in a specific situation." ${ }^{12}$

This situational dimension of preaching is linked directly to a specific space and a particular time, within which preaching takes place, and this dimension also creates certain 'spaces and times of tension. ${ }^{13}$ In the analysis, I will be focussing on the following times and spaces, and consequently, challenges for timing: the presence (or absence) of God; the presence (or absence) of the future; and the presence (or absence) of Christ in the Church. ${ }^{14}$

The sermon in question was preached during the late $70 \mathrm{~s}$ - a time of socio-political turmoil and civic unrest in South Africa - which forms the fundamental time and space of tension, within which Boesak endeavours to time grace. ${ }^{15}$ The broad coordinating system within which this sermon can be placed is the experience of threat on the one hand, and the intention to preach the gospel 'in a language that can be understood by persons in a specific situation ${ }^{16}$ on the other hand.

It is within this time and space of almost unbearable tension, this 'specific situation', that Boesak the preacher steps in and opens his mouth. ${ }^{17}$ He does

10 “Jesus Christ Frees ... and Divides." Boesak (1979:76-81). Direct quotations from the sermon are in single quotations. In some instances, I also compare Boesak's homiletical theory, as reflected in the preface to this compendium of sermons, to the sermon as such.

11 "What is true for theology is true for preaching: it is situational." Boesak (1979:7). Obviously, prophetic preaching can be described in various ways, also linked to cultural settings. According to Ottoni-Wilhelm prophetic preaching reminds us of at least the following: the fact that God is compassionate, not deserting that which God has created; that God has made certain promises, expressing God's enduring faithfulness; and that there are alternatives manifestations of God's inbreaking new world that can be discerned even in our darkest moments, Ottoni-Wilhelm (2003:84-91). See the discussion on 'situation' in Chapters 3, and further on in Chapter 6.

12 Boesak (1979:7). See the discussion on 'situation' in Chapters 3 and 6.

13 Boesak is acutely aware of this. Speaking about the authenticity of the preacher, he says: "Authenticity lies in the correct combination of exposition of the word, sensitivity to the situation of the congregation, and the inner conviction resulting from a personal experience of God's liberation in the life of the preacher." Boesak (1979:15). At least three tensions are implied here: the tension caused by the situation (context); the tension arising from the historicity of the biblical text; and the tension generated by the experience of the preacher.

14 These will be discussed in more detail in the analysis. Obviously more 'spaces and times of tension' could be mentioned here. Cf. Cilliers (1982:100-133).

15 See the discussion in Chapter 2.

16 Boesak (1979:7).

17 The 'theological' tradition within which Boesak stands, is Reformed, with a strong affinity particularly 
this, well knowing that he puts his life on the line. In his reflections on the act of preaching, he states: "The white government of South Africa has a vast array of oppressive laws that have an intimidating effect on the preacher. A sermon that is too clear may land the preacher in the hands of the dreaded Security Police, because such a sermon could, within the definition of the law, be anything from 'instigation' to 'terrorism.' To preach the word of God relevantly in South Africa is to walk through a minefield - blindfolded."18 Boesak himself knew this from own experience - a member of the Security Police pointed a gun at his head after one of his so-called 'political sermons. ${ }^{19}$ Without a doubt, the sermons of Boesak could be described as interrupting the time(s), and, in the same breath, as a brave effort at timing grace for, and in, the present, i.e. specific situation.

In what follows I offer an analysis of this sermon, again utilising the Heidelberg Method, ${ }^{20}$ this time combined with certain elements of the Grounded Theory Model $^{21}$ and the administrative support of the Kwalitan Computer Program. ${ }^{22}$ The Kwalitan Computer Program was initially used to identify certain key concepts in the sermon text. The Grounded Theory Model offers an inductive methodology that helps us to group keywords and phrases that occur throughout the sermon together as categories, binding it together as a communicative unity. The Heidelberg method aims to disclose the 'fundamental hermeneutic structures' of sermons. In the following analysis I will focus on this, while also venturing a 'theological interpretation'. The combination of these methods - all of which have been used within the South African context before ${ }^{23}$ - seems most adequate to address both the empirical reality of the

towards Calvin. Cf. Boesak (1979:14)'s comments on 'Reformed Christians', who 'ought to know better'.

Boesak (1979:5-6).

Narrated to the author of this book in a personal conversation.

See the discussion on this method in Chapter 3. Cf. Bohren and Jörns (1989:55-61). As indicated, I utilised a combination of the Heidelberg Method, the Ground Theory Model, and the Kwalitan Computer Program in this chapter.

21 According to Pieterse: “... the process of grounded theory analysis of sermons develops in a bottom-up approach in three cycles: (1) open coding as an inductive exercise, initial identifying of categories and the development of an open coding analytical model; (2) selective coding that is a deductive exercise in which sermons are selectively chosen for analysis on the basis of the hypotheses that are developed in the open coding analytical model; (3) theoretical coding and the construction of a theory of preaching on the theme of the analysis. Open coding is an inductive analysis of what the preacher says, teaches, admonishes, appeals, etc. in the segments and is coded in short sentences. The idea is to move from the code as a linguistic designator to concepts in the sense that the codes are treated as indicators for larger conceptual categories." Pieterse (2011:95-112); also Pleizier (2010:113). In this chapter I restrict myself to the first cycle, i.e. that of open coding.

22 This programme enables researchers to acquire qualitative data from written texts, for instance in the form of keywords, codes, categories of codes, etc., see Peters (2012). For an example of how this programme was used in the South African context, cf. Pieterse (2001:112ff.). 
sermon, as well as offering possibilities for a hermeneutical and theological reflection. The methodological procedure was therefore one of data collection/ selection; observation and interpretation, and (theological) reflection. ${ }^{24}$

It is important to keep in mind, however, that this analysis does not pretend to be the final word on this sermon. ${ }^{25}$ On the contrary, 'it intends to open up a provisional and experimental space within which the discussion about 'timing grace' can be fostered'

Let us now take a step back into (apartheid) time and listen to the voice of Allan Boesak.

\section{Jesus ChRIST FREES ... AND DIVIDES}

Do you suppose I came to establish peace on earth? No indeed, I have come to bring division.

(Luke 12:51) $)^{26}$

The coming of Jesus the Messiah is a sign of great decisions. The introduction to the Gospel of John makes this clear from the very beginning: this event - his coming - is something extraordinary, because here indeed is the revelation of 'the Father's only son, full of grace and truth' (John 1:14).

In Jesus the Father makes an incomparable and unrepeatable decision for his world and for his people. Through this decision old forms are affected in their innermost core, and the disorderly 'order' of this world is totally overturned and made unstable. The Messiah brings a new understanding, and a new (changed) reality.

God's decision for a changed world sets humankind before a similar decision.

God's decision about Jesus' coming forces humankind and the world into movement, because the decision is a powerful continuation of the liberation movement that he began with his people when he led them out of slavery

\footnotetext{
24 Cf. Pieterse (2011:113).

25 This analysis therefore does not profess to represent an exact image statistically of all (reformed) preaching from this time. But it can indeed say that preaching was also done like this. Naturally, there were other voices that expressed the 'situation' completely differently. As we have seen, there were also 'reformed' sermons - perhaps the majority - that made no mention of the situation. See the discussion in Chapter 3.

26 Scripture from the New English Bible (NEB).
} 
in Egypt. And just as it was impossible for the pharaoh and the Israelites to withdraw from this movement inaugurated by God, so it was impossible for persons to withdraw themselves from Jesus of Nazareth.

Time and again Israel was confronted by God and faced the decision whether they wished to go further with him. Every time the choice had to be made anew: either further 'with' God in faith to his promised land, or back to the reassurance of the fleshpots of Egypt. And later, when God had led them into the promised land, it was to be the same again. Then the choice was to be between Yahweh, the Living One, the Only One, and the idols; between trust in Yahweh and the temptation to follow Baal.

And each time this decision held the deepest repercussions for the people. And each time it brought dissension and division. So it was when Moses came down from the mountain and had to see how his people, while he was on the mountain struggling with God on their behalf, had begun to exchange, under the leadership of his brother Aaron, worship of God for worship of the golden calf. And then, once again, the challenge had to come: Moses 'took his place at the gate of the camp and said, 'Who is on the Lord's side? Come to me', (Exodus 32:26).

So, it was also when Elijah threw down the challenge to the prophets of Baal and thus also (how could it be otherwise?) to those who wished to be the people of God. How deep this decision cuts each time: "How long will you sit on the fence? If the Lord is God, follow him: but if Baal, then follow him," 1 Kings 18:21. This is the same God who in the same movement of freedom throughout history calls persons, in his decision to give his Son, in his choice for humankind, to make their own decision and choice.

When Jesus comes, he brings a painful and controversial tension. Inevitably he causes confrontation with tradition, with powers, with persons. He comes into collision with sinful attitudes, wrong structures, and vested interests. When his parents brought him to the temple and sacrificed two turtle-doves, Simeon prophesied: "Many in Israel will fall and rise again because of him," (Luke 2:34).

Confrontation with this Jesus makes it impossible for 'the ordinary life' to run its normal course. His radicality with respect to the law, the Torah, the attitude of the Pharisees and the scribes, bring him into conflict with tradition. His majestic association with the poor and the oppressed, with harlots and tax collectors, causes division among the people. His followers 
worship him as Lord and thus come into collision with the Roman state and the idolatrous emperor. He demands of his followers' faithful obedience and total trust; he demands of them the capacity to take up their cross, to regard everything else of lesser importance, and to follow him. Father and mother, brother and sister, husband or wife, are no longer all-important to his followers. Even the preservation of life is given a different, radical perspective by him:

If anyone wishes to be a follower of mine, he must leave self behind: day after day he must take up his cross and come with me. Whoever cares for his own safety is lost; but if a man will let himself be lost for my sake, that man is safe (Luke 9:23-24).

His hold on our lives is so total that all other human relationships have to be seen in another light. The word of the Torah, 'There is no other god besides me ..., becomes yet more radicalised in Jesus. and it is this fact that Jesus Christ is king, that $\mathrm{H} e$ has the last word over my life, that He rules over my total being - that makes it so difficult for us, and brings division and fire in its wake.

Therefore, the division caused among us South Africans by 'the enlightened' and 'the closed-minded', and the dissension brought about in the churches by the Koot Vorsters and the Beyers Naudés ${ }^{27}$ (think, for example, of the battle over sports policies) - all this is really nothing. The 'real' issue has still to come!

In the squabbling about sports policies Dr Vorster is of course correct when he says that sports must not become an idol. This is a very great danger in South Africa. But what is his alternative? The idol of ethnic identity? The purity of the 'volk'? How many bloody sacrifices have already been laid on its altar in our history? God is not yet even in this picture and the issues are not yet really important. No, the 'real' division has still to come!

When Christians in this country really take Jesus Christ and the demands of the gospel seriously, then his fire and his sword will become apparent.

27 Dr Koot Vorster was for many years the most famous leader of the white Dutch Reformed Church in South Africa. He was an unbending, articulate spokesperson for, and symbol of, the extreme right in Afrikanerdom. Dr Beyers Naudé was also an Afrikaner, and once a leader in the Dutch Reformed Church, but he committed himself to the struggle for justice in South Africa, and was later shunned by most Afrikaners, but respected by those in the struggle. He was banned by the government on October 19, 1977. See the discussion on Naudé further on in this chapter. 
Then it will be seen how dissension will really tear South Africa in two. But then at least it will be for 'something', for in the Bible the fire of which Jesus speaks is always a sign of purification. The fire separates the pure from the impure, and tests for what is lasting. Jesus says: "I have come to set fire to the earth, and how I wish it were already kindled!" (Luke 12:49).

He knows that he will have to go through this fire himself. He knows that he will not escape the testing and the purification, and "What constraint I am under until the ordeal is over!" (Luke 12:50). And the decision of those who go with him through the fire will bring division. Verse 51 can perhaps best be translated: 'No peace, nothing but division.' This shows how radical is this choice, how deeply it cuts, how final it is.

But how can Jesus say these things? What about the angels' message on the night of his birth? What of the song about peace on earth? What of the promise that his kingdom will be one of peace? Is there a contradiction here?

No, Jesus is not denying the angels' song. His critical words here apply to another kind of peace, the peace that is proclaimed and sung about when in reality there is no peace and there can be no peace. Just like Jeremiah in his time, so Jesus has no patience with the slippery merchants of piety who barter away genuine peace at the clerical market and try to palm off artificial products on the assembly of the Lord. Jesus desires a peace that is authentic. Not the sort of peace in which differences are patched over, sins are concealed, and irreconcilables are reconciled.

Jesus speaks of peace as the Old Testament understands it: God's longing that shalom should prevail on the earth. Shalom is the wish that things may go well with others. It is concern for the welfare of one's fellow beings. It is a sign of solidarity, of commitment to one another, of standing in for each other. In this peace, responsibility for each other - before God and before humankind - is embodied. In the Old Testament peace is always associated with right and justice. Peace is there as a 'socio-political' reality.

It is in this kind of peace that swords will be turned into ploughshares and spears into pruning knives. It is of this kind of peace that Jesus speaks. For this reason, he opposes a superficial understanding of this word to which God himself has given content and meaning through his love and his liberation. 
Peace, yes, but it must be genuine. Peace is not the power to pose a greater threat to the other with my better and more sophisticated weapons. Peace is not possible while thousands suffer hunger and the uprooting of communities and the destruction of families are glibly argued away with euphemisms such as influx control.'28 There is no peace while millions are oppressed, and while right and justice openly stumble in public. There is no peace as long as conditions that give rise to hatred and bitterness, to repression and rebellion, are regarded as God-given. There is no peace while justified protest is smashed into the ground in the most brutal way. Let us not mislead ourselves: there is no peace.

The peace of God is different from the peace of the world. It is not only the absence of war, but the 'active presence of justice'. And as long as injustice rules, no church and no Christian may not be at peace with themselves and the world. If Christians in South Africa are not purified in the fire of God's love, then we shall be consumed in the fire of his wrath.

The peace of God is a summons to battle with sinful structures, with those who resort to injustice, with the prejudice and sin in my own heart - with everything that obstructs his true peace. We have to make peace with him and with each other, and quickly too. To paraphrase for our situation the famous saying of Martin Luther King, Jr: I am convinced that we shall still have remorse in our time, not only over the poisonous words and the detestable actions of evil persons who take no account of God and give his word no place in their lives, but we shall also have remorse over the horrifying silence and the indifference of the good persons who did not know 'what served their peace'.

If we are honest, we have to admit that the words which Jesus said in tears over Jerusalem also apply to South Africa:

If only you had known the path to peace this day; but you have completely lost it from view! Days will come upon you when your enemies encircle you with a rampart, hem you in, and press you hard from every side. They will wipe you out, you and your children within your walls, and leave not a stone within you, because you failed to recognise the time of your visitation (Luke 19:42-44).

28 An expression used by the South African government in reference to its limitation of the rights of black people to reside in areas reserved for white people. 
If only South Africa would listen so that we could know what serves our peace. If a Christian people would only stop shouting its own prophets down, ignoring them, shutting them up in prisons where they are treated as if their lives were not worth a cent. If Christian leaders would only stop glossing over evil, thereby strengthening evildoers in their evil. If only we would stop twisting, mutilating, and manipulating God's word to make it fit the framework of the prevailing ideology. If only we could find the courage to speak the truth to each other and not to mislead each other for the sake of money or status, or out of fear.

It is painful, but we shall have to learn to accept that our obedience to Christ will also bring divisions within the church. We shall not always have everyone go along with us. And it would be wrong to sacrifice genuine peace for the sake of external conformity. We cannot indefinitely postpone doing what is right simply because not everyone is willing to go along with us.

Obedience and dedication to the Lord's work will bring division and a lack of peace. And of course, they will then take sides against each other. But then it will no longer be on the grounds of race or colour or ideology, but on the basis of our willingness or unwillingness to follow the Messiah on his way through history. We seek not the peace of the world, but 'His' peace, the peace of him who has made us one in him, and who has broken down the divisive wall of hostility.

We now turn our attention to the analysis of the sermon.

\section{Analysis}

\section{Primary and secondary codes}

A scrutiny of the sermon following the notion of 'open coding' reveals the following most often repeated phrases - grouped underneath as the 'core code', with 'secondary codes.'The core code indicates the dynamic key concept - mostly found in the form of a 'verb', in accordance with the definition of preaching as an 'event' - on which the basic structure of the sermon in fact hinges. ${ }^{29}$ The core code (not necessarily inferred from the number of repetitions) appears

29 See the discussion on 'preaching as an event' in Chapter 2, as well as 'timing as an event (happenstance)' in Chapter 1. 
at certain key moments in the sermon; the secondary codes are connected to/dependant on this core code.

\section{Primary code}

» Jesus/God/humans 'come'; are in 'movement'30

\section{Secondary codes}

» Jesus/God/humans decide/choose ${ }^{31}$

» Jesus/God/humans divide ${ }^{32}$

» Jesus/God/humans long for peace ${ }^{33}$

» Really/real/reality ${ }^{34}$ - used mostly as emphasis

We now take a closer, analytical look at these different codes.

\section{Timing:" "The coming of Jesus ..."}

The very first sentence of the sermon sheds an interesting light on the preacher's understanding of the 'coming of Jesus' (the core code): "The coming of Jesus the Messiah is a sign of great decisions." ${ }^{35}$ Three observations are of importance here, as they also have an impact on th uses the nominalisation of the verb ('The coming of ...'), and not the active, indicative form ('Jesus comes ...'). One could say: this nominalisation of the verb represents a type of general description of 'the coming of Jesus'; not so much as a performative articulation of this coming. The 'coming of Jesus' is still historically abstract, not revealing 'how' and 'when' Jesus comes, at least in South Africa, today. ${ }^{36}$ 'The timing of this coming is still left open'.

The second observation concerns another important word in this first sentence, namely the word 'is'. 'Is' is the present tense, here pregnant with meaning. It means - so, it is, and so it must be. Or, in theological terms: 'is' contains and combines the indicative and the imperative. The first part of the sermon strives to proclaim the 'coming of Jesus', the how and when thereof, in

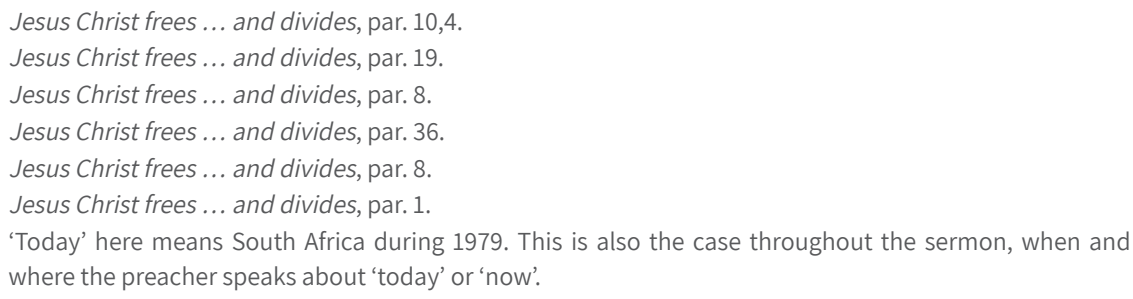


clear indicative terms, by referring to a number of biblical instances, which the preacher defines as God's 'liberation movement', and 'movement of freedom. ${ }^{37}$ But the potential for the imperative - which is strongly emphasised later in the sermon, is also already implanted in the word 'is'.

Thirdly, the potential for emphasising the imperative is furthermore enhanced in the way that the preacher slightly adjusts the biblical text that he uses as basis for his sermon in this first sentence. ${ }^{38}$ The text articulates the words of Jesus: 'I have come to bring division'; the preacher speaks of 'decisions.' This secondary code is repeated 19 times throughout the sermon, and the first sentence already indicates the preacher's intent: to call upon his listeners to 'decide', to 'choose'. Although he does use the term 'division' - another secondary code, found 8 times - which underlines the idea that God initiates this action, the notion of 'decision' offers a better platform to speak about human responsibility and even 'capacity' later on in the sermon..$^{39}$ It is also interesting to note that the first sentence is in the form of an 'impersonal construction' - 'a sign of great decisions' - without revealing who in fact 'makes' these decisions.

This brings us to a second occurrence of the core code.

\section{Timing:" "When Jesus comes..."}

Now the preacher no longer speaks of 'the coming of Jesus' in a nominalised construction, but he prefers the verbalised form: 'When Jesus comes ...40 This seems like a step towards answering the question that was evoked by the first sentence of the sermon: how and when does the 'coming of Jesus' in

\footnotetext{
Jesus Christ frees ... and divides, par. 4,8.

It is not possible to do an extensive 'exegetical reading of the biblical text and/or pericope' within the limitations of this chapter. The following broad strokes are however relevant for the 'analysis of the sermon text': Firstly, the pericope in Luke from which the sermon text is taken, forms part of the narrative of Jesus' 'journey to Jerusalem' (starting in 9:21), and his 'escalating contrast to and conflict with' the Pharisees and Lawyers (cf. 11:37-54). The text that the preacher uses as basis for his sermon is furthermore part of the segment that calls for a 'preparation for the coming judgement' (12:1-13:9) and is followed by an extended segment about reversals now and to come (13:10-14:35). Secondly, the pericope is drenched in Old Testament language and symbolism. For instance, the fire here denotes 'God's intention' to purify God's people in 'God's time'. For this purpose, Jesus also came to the earth - to realise 'God's Kairos'. Thus, Jesus does not stand as fiery Judge against the world - He himself will be judged, will be immersed in fire. He knows and expects this but awaits 'God's timing' of this (eschatological) event. Thirdly, it is important to note that it is not clear 'how Jesus is to be seen to be initiating this conflagration'. The reader is rather left with puzzling, paradoxical speech, e.g. the apparent clash between 'fire' and 'peace'. Nowhere, however, is it expected of the church - or followers of Jesus - to initiate the how and when of 'God's Kairos' in Jesus. It remains an eschatological, and in this sense, also Christological event. For good overviews of this pericope, cf. Patterson (1989:121-139); Sellew (1987:617-668); Vögtle (1976:51-113); Nolland (1998:131ff.). 
fact take place in South Africa, today? But it is interesting to note that the preacher - rhetorically gifted as he is - does not answer this question, at least not at this stage of his sermon. He keeps the suspense going. The 'conditional terms' of the how and when remain open.

But the preacher in fact does 'prepare the ground' for answering this question carefully and rhetorically. It is significant to see that the imperative is used quite emphatically in the section following this "when Jesus comes ..." One could say that the potential for the imperative that was given in the first sentence of the sermon now comes to fuller fruition. Now 'is' does in fact mean 'should be'; now 'decisions' should in fact be made. But all these imperatives are still taken as examples from biblical incidents, i.e. they are not at this stage of the sermon directed at listeners in South Africa, today.

Many examples of this emphasised imperative can be pointed out in this section, perhaps culminating in: 'He demands of his followers' faithful obedience and total trust; he demands of them the capacity to take up their cross ..." ${ }^{41}$ These imperatives are surrounded by strong words, like 'painful and controversial tension'; 'confrontation'; 'collision'; 'radicality'; 'division'; 'radical'; 'more radicalised', etc. ${ }^{42}$

This paves the way for the third nuance of the core code.

\section{Timing: "... the real division still has to come!"}

The preacher now starts to shift his attention to the listeners in South Africa, today. In a bridging paragraph, he speaks of Christ's hold on 'our lives', about the fact that 'he has the last word over my life, that he rules over my total being - that makes it so difficult for us ...43 For the first time we hear 'our', 'my' and 'us'. Then comes the bridging word - we often find variants of these in sermons - linking the first part of the sermon with that which is to follow: 'Therefore ...'44

Again, the emphases catches the eye. The word 'really' - another secondary code in the sermon, repeated 8 times in different forms - comes to the fore. But what is even more significant in this turning towards the listeners in South Africa, today, is the change in verbal tense. While the present tense was

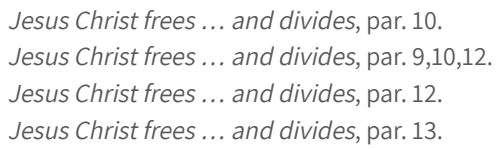


used predominantly in the first part of the sermon, inter alia to express the 'reality' brought about by 'the coming of Jesus, ${ }^{\prime 4}$ the future tense now takes over, strengthened by the use of emphasis. Now we hear: 'The 'real' issue has still to come!' and 'No, the 'real' division has still to come!"46

One could say: the reality of the peace that Jesus has brought, referred to in the first part of the sermon, and expounded in the closing section of the sermon, becomes the peace that Jesus will still bring - in the future, when certain conditions are met. The future coming of division places peace - another secondary code (repeated 36 times) - on hold.

Even the God-image of the preacher changes, or is at least affected by, this transformation of tense. In the first part of the sermon he stated that through God's decision for the world 'old forms are affected in their innermost core'; in this section we hear: 'God is not yet even in this picture ...47

This prompts an array of questions: how then must or can God be brought (back?) into the picture? How can peace become 'real'? What conditions must be met to activate the 'when' and 'how' of 'the coming of Jesus' and 'when Jesus comes' and the 'real issue that still has to come'?

These questions lead to the fourth articulation of the core code, offered by the preacher.

\section{Timing: "When Christians really take Jesus seriously, then his fire and sword will become apparent"}

Because 'real' division (and consequently 'real' peace) lie in the future, the listeners of South Africa, today ('Christians in this country'), are called up with the imperative to 'really take Jesus and the demands of the gospel seriously'. 'When' this happens 'then it will be seen how dissension will really tear South Africa in two. ${ }^{48}$ Linguistically speaking, this emphasis means: only the 'real' seriousness of Christians will or can lead to 'real' division, i.e. the 'real' gospel. The condition is clear: 'when ... then'.

With this unfolding of the core code of the sermon, the potential for imperative, already found in embryonic form in the first sentence of the sermon, reaches

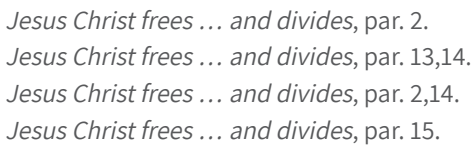


its rhetorical climax. At least on a linguistic level, this structure means that the 'coming of Jesus' is now determined by the 'real' seriousness of Christians. 'Coming' becomes 'becoming' - through the 'faithful obedience and total trust' of the followers of Jesus, as well as the 'capacity to take up their cross, ${ }^{\prime 9}$ as the preacher stated earlier in the sermon. The immediate relevance and reality of the Messiah now becomes a mediated relevance and reality; 'the coming of Jesus' becomes dependant on 'temporality and human timing' - 'when' they are serious. We noted that the preacher used an 'impersonal construction' in the first sentence of the sermon - 'a sign of great decisions' - without revealing who in fact 'makes' these decisions. Now, this impersonal construction is dissolved in the ecclesiological imperative: 'When Christians ...'

This structure determines the rest of the sermon, or at least throws its shadow over it. The preacher for instance states: "And the decision of those who go with Him through the fire will bring division." ${ }^{50}$ We are again reminded of the preacher's use of 'decision' in the first sentence of the sermon, instead of division (as in the bible text). In this instance the division that Jesus brings, does not lead to our decisions; our decisions rather lead to divisions. Here the continuity of the 'liberation movement' of the Messiah through history becomes the chain reaction of momentary 'decisions' of serious Christians in history. No longer does Jesus make peace with us - we 'now have to make peace with him ...

\section{Retrospective Reflection}

The sermon represents a brave effort to confront the status quo and preach against the powers that be. It could justifiably be called 'prophetic preaching that strives to address a concrete situation' - in accordance with Boesak's own understanding of preaching..$^{52} \mathrm{He}$ articulates his aversion of pietistic traditions and preaching in the church in no unclear terms, stating that "this kind of theology is often the handmaid of authoritarian structures that preserve the status quo within the church, with the result that the church is being held back to an era that has irrevocable passed".53 For Boesak, the gospel - and preaching - is about 'this' world, not an 'other-worldly theology' ${ }^{4}$

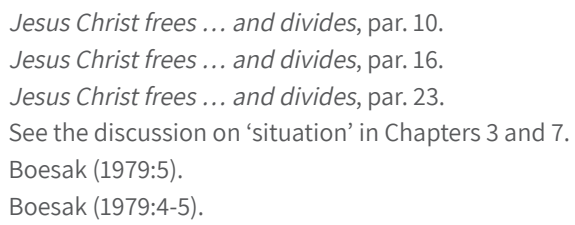


In my opinion, it would not be an exaggeration to say that, to a certain extent, we still suffer from such forms of pietistic, 'other-worldly' theology and preaching in South Africa, and perhaps even more so than before. We still need a prophetic voice that challenges this trend. ${ }^{55}$ For this, the sermon of Boesak gives valuable food for thought.

Obviously, prophetic preaching can be described in various ways, also linked to cultural settings. According to Dawn Ottoni-Wilhelm, prophetic preaching reminds us of at least the following: the fact that God is compassionate, not deserting that which God has created; that God has made certain promises, expressing God's enduring faithfulness; and that there are alternatives manifestations of God's in-breaking new world, to be discerned even in our darkest moments. ${ }^{56}$ Looking back at Boesak's sermon as an example of 'timing grace' during the time of apartheid, how could or should we then evaluate it? I venture a few brief comments - using Ottoni-Wilhelm's understanding of prophetic preaching as broad parameters:

Firstly, it would seem fair to state that the preacher's 'hermeneutical structure' is decisively influenced by his experiences under apartheid. For him, the situation under the apartheid government is so bleak and dangerous, so godless, that he interprets it in exactly this way: Godless, Jesus not-being-in-the-picture. This then becomes his 'intention' with his sermon: 'To bring God back into the picture, and the way to achieve this is by calling on the Christians in South Africa to act in such a manner that God can again be (experienced as) present in the South African situation.'

One could ask whether this intention does not open up one of the most profound times and spaces of tension to be found or created in any form of preaching - the 'presence of God's absence, and the absence of God's presence. ${ }^{57}$ Or, in other words: of God being present - God is compassionate, not deserting that which God has created ${ }^{58}$ - and yet being (experienced as) elusive, as 'not being in the picture.' The 'situation' under apartheid seems to have radicalised this fundamental space of tension - forcing Boesak to opt for the latter (God not being in the picture).

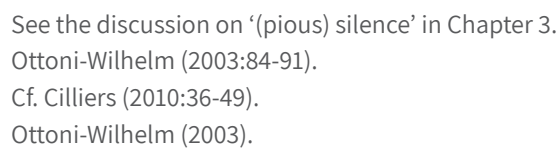


Secondly, Boesak calls upon his listeners to act in a certain way with an eye to the 'future.' He expects divisions and confrontations as a direct result of the earnest obedience of Christians in South Africa; he even foresees a chaotic future and suggests that the present is but an introduction to the greater crises, which loom over South Africa - the 'real issues' are still to come. Boesak's sermon hopes to call forth the future, so that the status quo can be shattered - in contrast to 'the silence that some want the church to maintain on these issues (which) means that they are affirming the status quo. ${ }^{59}$ In Boesak's sermon, there is a search for what does not yet exist, namely true Christianity - when people will 'really' be earnest and 'radically' obedient.

Perhaps the conviction that underpins this stress on the future can be connected to Boesak's understanding of God's promises. According to Ottoni-Wilhelm God 'has' made certain promises, expressing God's enduring faithfulness. This brings us to another profound time and space of tension within Boesak's prophetic preaching - that of 'the future of the presence, and the presence of the future. ${ }^{60}$

Obviously, the future by implication means 'not now' - the future is the future - but, as I have already pointed out earlier, this is often misunderstood as an experience of time exclusively related to a futurum, i.e. an attitude or mentality that somehow bypasses the present in its eagerness for the future. ${ }^{61}$ In the New Testament sense of the word, the future is more about adventus (the coming of the present One), than it is about futurum.62 Once again, it seems that the 'situation' under apartheid has radicalised this fundamental time and space of tension - tempting Boesak to favour the latter (the futurum).

Thirdly, the basic intention of the sermon also has far-reaching implications for the ecclesiology implemented by the preacher. Boesak clearly expects much from his listeners. In a certain sense, the future is made dependant on the actions of Christians in the present, even to the point where 'the coming of Jesus' flows forth from the chain of decisions made by Christians in South Africa. In this process Christology functions in an exemplary manner: Christ is the great and ultimate example of how Christians should make their decisions in the present; He is the culmination of a series of acts of God, but also the main Player in the Christians' history of decision-making. In effect, Christ is shifted out to the

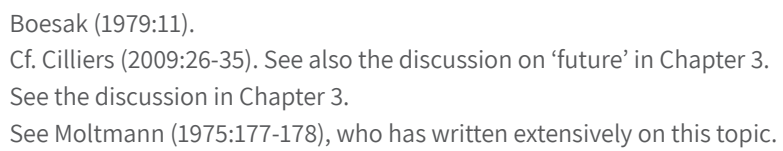


future, and Christians are called upon to move towards this future by means of their devout 'seriousness'.

This confronts us with yet another profound time and space of tension - that of 'Christ in the church', and 'the church in Christ'. On the one hand, there is truth in what Boesak propagates. In a certain sense it is true that Christ is present in this world in the form, and through the mediation of, the church. We are reminded of Bonhoeffer's 'definition' of the church as: 'Christus als Gemeinde existierend. ${ }^{63}$ This means that Christ exists in this world 'as' church. And furthermore: the world (or, in this case: South Africa), will see Christ through the (devout and earnest) actions of the church. Christ 'is' in the church.

But does this mean that the church is (always) in Christ? That our hope of seeing and experiencing Christ and his peace is (always) dependant on the church? Can the 'adventus' of the Messiah (the coming of the present One) only be found in the serious devotion of Christians? Or, again in the words of Ottoni-Wilhelm: does the church offer the only viable alternative of God's infringing new world, to be discerned even in our darkest moments? It would seem, once again, that the situation under apartheid has radicalised this time and space of tension - causing Boesak to proclaim the latter (the serious devotion of Christians being the alternative).

So, the sermon of Boesak, preached in the late 70s, prompts us to rethink certain times and spaces of tension when preaching. It reminds us that the gospel is heard within the tension of - amongst others - these times and spaces: the presence (or absence) of God; the presence (or absence) of the future; and the presence (or absence) of Christ in the church.

In conclusion, at least this critical question must linger: is the 'coming of Jesus' indeed dependant on the 'real seriousness' of Christians, and their 'capacity' to take up the cross? Is this in fact the (only) way to fill up the 'now'? If that is the case, South Africa is in trouble again, today (i.e. in 1979, and in 2019). 'Really seriously' in trouble.

\section{Speaking truth to power ...}

Boesak's sermon in effect calls for a deeper, critical perspective on the powers of the day - he indeed 'speaks truth to power. ${ }^{64}$ I would call this perspective 
a 'reversed, bifurcated sense of time and space.' It has been pointed out that literature like the Book of Revelation in fact offers such a bifurcated view, in the sense that two realities, i.e. that of the Roman Empire and the deeper, often hidden reign of God 'coexist at all times and places.'.5 One could, however, easily overlook the hidden reign of God, seeing only the seemingly evident rule of the so-called powerful. Preaching then, could be described as the unveiling of the reality of God's presence, in the same spaces and times that are occupied by the powerful. ${ }^{66}$

Boesak does exactly this - unveiling a deeper, hidden reality, whilst facing the powerful. In this particular sermon, he emphasises the fact that not only is the rule of God the ultimate reality, but that the powerful will pass by, be revealed as powerless, in the end 'when Jesus comes' - it is only a matter of time.

Coexisting in all spaces and at all times with the powerful is not only the reality of God's coming, but also comprise mortality and death.

In this regard, an artwork by Hans Holbein (Jr) is truly remarkable. In fact, I believe that it offers a distinct, homiletical paradigm. ${ }^{67}$

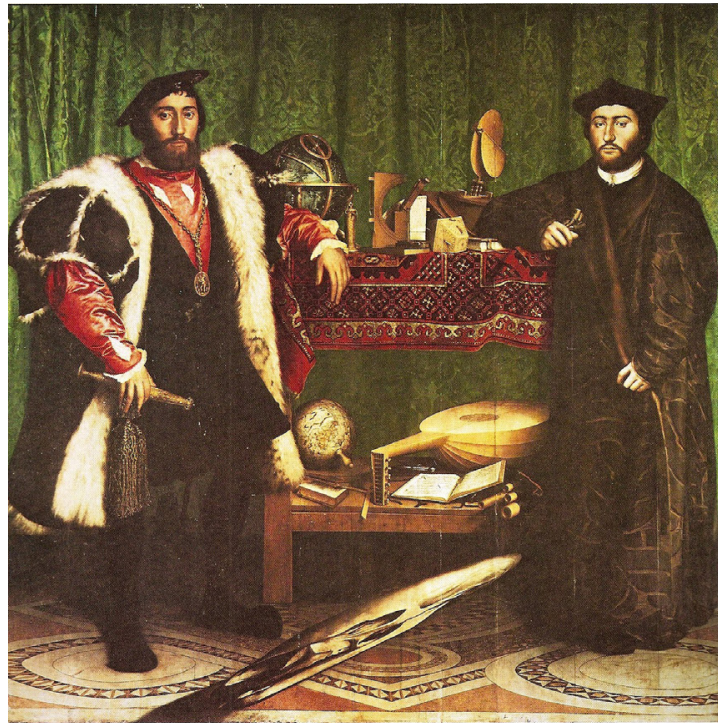

Figure 4.1 Hans Holbein's The Ambassadors (1533) (Public Domain)

65 See the enlightening work of Howard-Brook and Gwyther (1999:120-135).
66 See the discussion in Chapter 7.
67 See my discussion in Cilliers (2004:64ff.). 
Holbein painted, The Ambassadors, in 1533, depicting two wealthy and well-educated young men, both French diplomats, viz Jean de Dinteville and Georges de Selve. The painting was created during a time in Europe's history that was characterised by momentous upheavals and battles, between the political powers (Henry VIII), and the Pope of the Catholic Church. Somehow, Holbein makes all this relative to being folly, being also known for his woodcut illustrations for the Dutch scholar Erasmus's satirical essay, The Praise of Folly. Many powerful figures from this era, from both the political and religious order, took the world to the brink of war - people like King Francis I of France, Holy Roman Emperor Charles V, and the Pope.

Holbein's remarkable painting was created within the context of the Renaissance - a notion that positioned humans in the central position of creation, in a sense masters of earthly and heavenly realms. Against this temporal background, it is interesting to note that almost all the elements in the work reflect the 'cyclical narrative' of humanity and death, and, at the same time, it depicts the unstoppable, 'linear onslaught' of time. ${ }^{68}$

The meaning of the polished marble floor could easily be overlooked. It has been noted that the pattern of the floor corresponds with that of the sanctuary in Westminster Abbey, originally inscribed with the phrase Spericus archetypum, globus hic monstrat macrocosmum ('This spherical ball shows the Macrocosmic archetype'). This places the picture within a broader, macrocosmic framework, combined with a rich variety of cutting-edge scientific instruments, contemporary mathematical treatises, and musical scores from that period. ${ }^{69}$

The objects on the upper shelf are all somehow linked to the heavenly realm - a celestial globe, a sundial, and various other instruments used in astronomy and for measuring time. The objects on the bottom shelf point towards earthly pursuits - a terrestrial globe, a compass, lute, case of flutes, and open hymnbook. A closer look reveals that the lute's string is broken - perhaps a reference to the ecclesiastical discord of the day. The hymnal, on the other hand, lies open at the Veni Sancte Spiritus, a supplication to the Holy Spirit, traditionally invoked in view of church unification. ${ }^{70}$

The painting in effect juxtaposes power and the reality of powerlessness, of death. One of the Ambassadors, De Dinteville, standing on the left, appears

\footnotetext{
See the discussion on 'cyclical and linear time' in Chapters 1 and 3.

Butler, Van Cleave and Stirling (1996:226).

Butler, Van Cleave and Stirling (1996:226).
} 
as a man of action, apparently clutching a sheathed dagger, while the other Ambassador, De Selve, rests his arm on a book, suggesting education. A closer look again reveals the motive of the artist: both the dagger and book are inscribed in Latin with the ages of the two Ambassadors, 29 and 25, respectively. In effect the artwork underlines the fact that, although these men appear vital and young, their lives are dated, and their time(s) running out. De Dinteville's cap even has a brooch attached to it, featuring a skull!

The reality of mortality permeates the whole picture - keeping in mind that rampant epidemics of fatal diseases such as plagues were common and resulted in short lifetime expectancies. Both these men, even Holbein himself, died at a relatively young age. The historical fact that both these two young men were extremely gifted deepens the irony of the painting: while posing for the painting they were terminally ill. Both died at a young age.

The most remarkable indication of mortality can be seen in the elongated skull at the bottom of the picture, a type of a memento mori ('remember that you will die'). The distorted skull obscures the centre of the world as it (literally) covers the middle circle on the floor pattern. It 'interrupts' the belief that humans can create and maintain a unified, or wholesome, world, despite the Renaissance. ${ }^{71}$ But, importantly, the perspectival skull can easily be overlooked; it is not necessarily perceived, or understood, at first glance. It calls for a specific perspective on life, and on the powerful and all notions of power in this world. Suddenly, one sees the wealthy, well-educated young men, as well as the renaissance of human aptitude around them, in a more complex, transient perspective. The skull says: the young, the strong and the intellectual also have a skull at their feet. They too do not escape the pull of the grave.

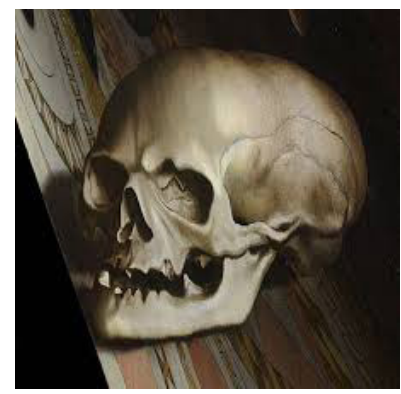

Figure 4.2 Hans Holbein: The Ambassadors (1533): The Skull seen from side-perspective (Public Domain)

71 See again the 'notion of interruption' in Chapters 1 and 2 
And yet, subtly, all is not death, in this picture. In the top left-hand corner, partially hidden by the emerald green backdrop (peeping into the picture from behind, as it were), a crucifix stands for resurrection, for new life, for hope. One literally must stand close to the artwork to discern this. The idea of life and hope is also alluded to in the cylindrical sundial, which is set to April $11^{\text {th }}$, the date of Good Friday in 1533. Again, not all viewers see, or understand this, at least not at first glance. Here also, in order to perceive hope amid death, one needs a way of seeing; a distinctive perspective.

If Boesak's sermon represents a 'moral discourse of indictment', Holbeins's painting represents a 'moral aesthetics of indictment'. If Boesak's sermon uses words to speak truth to power, Holbein's picture uses images to portray truth to power. Both say: if the powerful seem to be eternal, look again: it is only a matter of time, before they are gone. Now they may still hold sway, but their time will soon be up. Just imagine being so unveiling, so 'interruptive' of the powerful time(s) and players of apartheid ...

Let us now turn to Archbishop Desmond Tutu, who, in his own way, unveils power as fleeting, 'powerless power' - and points towards 'imaginative alternatives'.

\section{Desmond Tutu: a utopian mode of moral discourse}

\section{Global Guardian}

The complex nature of South African society poses several challenges to anyone who dares to speak about political-ethical preaching, i.e. preaching that endeavours to 'time grace' in terms of concrete situations. ${ }^{72}$ The pluralistic fabric of our South African society makes it difficult to describe the notion of 'ethical preaching', or 'ethics' for that matter. What is 'right' for one (or one group), may be 'wrong' for another; and what is 'wrong' for one, may be 'right' for another. When South Africans speak about 'change' or 'transformation, they are not necessarily on the same page. The best we can hope for in our pluralistic society is a type of 'bricolage' among different dialogue partners who speak out of, but hopefully also beyond their own traditions. ${ }^{73}$

Following the distinctions made by Gustafson concerning the modes of ethical discourse, already referred to above, I would say that former Archbishop

See again the connections drawn between 'ethics and improvisation, i.e. timing', in Chapter 2. What follows, is a revised version of Cilliers (2015:41-56).

73 In this regard, Bricolage refers to the borrowing among partners of what is handy, appropriate and communicative in jostling, negotiating and persuading towards a common moral sense. Cf. Cahill (1994:373). 
Desmond Tutu practised a so-called 'utopian mode of moral discourse', using language that not only reveals the defects of the status quo, but creates pictures of a hopeful vision, of a better future - even in the darkest hours of apartheid. ${ }^{74}$

In what follows, I limit myself to brief comments on some sermons, speeches, and letters by Desmond Tutu - that 'tiny pastor with a huge laugh from South Africa who became our global guardian.75 I do this because Tutu has become known, inter alia, for his ability to do exactly this: speaking from his Christian convictions in such a manner that it is applicable beyond his convictions. ${ }^{76}$

In order to understand his approach to ethics, one should keep Tutu's basic Ubuntu paradigm in mind - which, for me, offers another example of what I call a 'spiral-communal' understanding of time. ${ }^{77}$ Earlier, when I considered the connections between preaching and space, I came to the conclusion that space and time can only be linked meaningfully by means of community. I reiterate:

Speaking from an African perspective, it could, for instance, be said that time and space can only coincide meaningfully within the context of 'community'. The basic structures within which we exist ... would then not only be time and space, but also community. Time and space are transformed and converged into Kairos within community. ${ }^{78}$

One could say that Tutu's approach is all about the restoration of community in the aftermath of the devastating separation of communities during the time of apartheid. In this sense, he intends to bring South Africans back into the circle, but the latter not being an exclusive one, rather a circle of community that can be celebrated. ${ }^{79}$ In short: Tutu believes that I am, because you are; that we are, because we exist together, i.e. he believes in Ubuntu.

The concept of Ubuntu, as a unique, although somewhat elusive, expression of community, has become well known all over the world as being typical of African and specifically South African culture. Although Ubuntu as an African cultural expression could strictly speaking not be called 'theology', there are many prominent theologians who interpret this concept in theological terms.

\footnotetext{
See Gustafson (1988:269ff.), and the discussion at the beginning of this chapter. Alex Perry, The Laughing Bishop, Time Magazine, Monday 11 October 2010.

One of the famous sayings of Tutu is: "I am such a good ecumenical, because I am such a good Anglican." See the discussion in Chapter 1.

Cilliers (2016a:157).

See the discussions on 'the meaning of 'circle' within the African context' in Chapters 3 and 7.
} 
Desmond Tutu, for instance, has developed and practiced what could be called a 'theology of Ubuntu'so

Tutu's theology is probably one of the most representative expressions of African Ubuntu. For Tutu, Ubuntu has a profound theological meaning, because God has created us to need each other. We are made to be part of a 'delicate network of interdependence ${ }^{\mathrm{s}}{ }^{81}$ In this ethical paradigm, being there for one another is of paramount importance. One could indeed say that Tutu has been a proponent of 'sacrificial ethics', rather than an achievement ethics. ${ }^{82}$

Following the cues left by Desmond Tutu, I offer three brief perspectives on 'ethical preaching, or 'timing grace', taken from our past, and our present. These perspectives, or rather movements, are intertwined, and I venture them, knowing well that there are many more that could be explored.

\section{Timing (as) confrontation}

In a remarkable letter, which remained unpublicised for more than three decades, Tutu addressed the then Prime Minister, P.W. Botha, and confronted him about the forced separation of white and black people in South Africa in no uncertain terms - specifically in terms of the forceful removal of between two and three million black people from their homes. ${ }^{83}$ This letter was written on 5 July 1979 - as we also have noted above, a time of socio-political upheaval in South Africa as seldom experienced before. ${ }^{84}$ The tension of this catastrophic phase of South African history forms the contextual background of the letter - a profound ethical 'sermon' in its own right, speaking to the 'times of turmoil' in Tutu's inimitable manner.

In a moving fashion, Tutu appeals not only to P.W. Botha's Christian belief ('as one Christian to his fellow Christian'85), but he makes liberal use of passages of Scripture, and he ends the letter by stating that he will continually pray for P.W. Botha and his colleagues, 'that you may be instruments of his divine gracious will in this beautiful land which we all love so deeply ${ }^{86}$ It is exactly

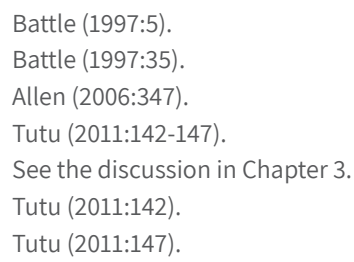


'within this profound theological framework' that Tutu speaks some of his sharpest words of confrontation, of struggling with the system of apartheid:

I write to you to say that the policy of population removal and resettlement is quite indefensible on moral and pragmatic grounds ... But it is the moral aspect that has shattered me and that I believe you and your colleagues must be unaware of. And it is that human persons are treated as if they are less than that. I must be careful not to use emotive language, but Mr Prime Minister, I cannot avoid speaking about the dumping of people as if they were things, with little prior consultation about how they felt about things and almost certainly scant attention being paid to how they feel ... I am trying to be as restrained as possible because I want to confess to you that at this moment as I write I am deeply agitated and angered by what I have seen ... We want justice, peace, and reconciliation in our land, and these will come as we strive to remove all which makes people less than what God intends them to be. We will be free together or not at all. ${ }^{87}$

There seems to be almost something Pauline about this ethical approach and struggle of Tutu: he appeals for change on the grounds of the reality of an identity, in this case - the outspoken Christian belief of P.W. Botha, and that of the whole apartheid government, for that matter. ${ }^{88} \mathrm{He}$ is agitated and angered, because P.W. Botha and his government are not acting according to the ethical parameters of their so-called Christian confession. This basis of appeal adds theological gravitas to Tutu's analysis of the situation, making it difficult for the addressees to ignore. ${ }^{89}$

Fifteen years after Desmond Tutu wrote his letter to P.W. Botha, on 27 April 1994, the first democratic general elections took place, and South Africa's young democracy, the 'Rainbow Nation', recently celebrated its twenty-fifth birthday. The times have moved on since the dawn of democracy, and there is much to be applauded about the developments in our country, but also much to be

87 Tutu (2011:143-146)

88 Apartheid was openly sanctioned by certain Christian Churches such as the Dutch Reformed Church, and many of the members of Parliament were leaders (elders and deacons, even former preachers) in these churches. For Paul's view on ethics cf. Hansen (1994:25ff.).

89 Indeed, "... it is clear that some of the most effective 'prophetic preaching' in our time by such dazzling voices as Desmond Tutu ... has the power of indignation, but comes across as utterances of hope-filled, compassionate truth-telling largely free of rage." See Brueggemann (2003:73). In this instance, Tutu argues based on his and P.W. Botha's Christian beliefs. Many of his ethical stances are however also applicable to other religions and non-Christians. He keeps on insisting that 'God is not a Christian', and that there is a moral core to the Universe - of importance for people of all races, but also beliefs. Tutu (2011:3ff.,206ff.). 
lamented. Many people feel that we need ethical preaching again, but that the prophets have gone, that (un)ethical silence has once again fallen upon us. ${ }^{90}$

Embedded in Article 15 of the Bill of Rights of the South African Constitution (drafted in 1996), are the three principles of freedom of religion, belief and opinion. These principles give recognition to the reality of religious diversity in South Africa, the separation between religion and state and equal opportunities for all religions in societal life. ${ }^{91}$ Although this might seem like an utopian state of affairs, the effect could in fact be a 'new syndrome of silence' in South Africa - no longer feeling the need to speak out against certain ethical issues in society. This temptation does not only apply to churches who supported the former liberation movements whose members are now in government, but also to those churches who supported the apartheid system and who intends to restore their credibility in the South African society. The former opponents of apartheid run the risk of showing uncritical loyalty to the current government, while the former defenders of apartheid might easily succumb to the temptation of political correctness, and a consequent uncritical stance towards the government, in view of regaining public credibility. ${ }^{92}$

This, in my opinion, is in fact what is currently happening in South Africa. Between uncritical loyalty and political correctness, the ethical voice of the church has, to a large extent, been silenced, and in effect, neutralised. We might - once again - be mistiming the grace of the present. ${ }^{93}$

\section{Timing (as) celebration}

But, now as in the past, swimming against this stream, Tutu calls upon South Africans 'not to be silent, or to be separated again, but rather celebrate their diversity'. This is a theme that has dominated the ethical thought of Tutu from the beginning. In a speech to the United Nations' Commission on Human Rights in Geneva in 2001, Tutu states:

We belong in a world whose very structure, whose essence, is diversity, almost bewildering in extent. It is to live in a fool's paradise to ignore this basic fact ... We live in a universe marked by diversity as the law of its being and our being. We are made to exist in a life that should be marked by cooperation, interdependence, sharing, caring, compassion, and

\footnotetext{
90 Cf. my discussion in Cilliers (2014a:125-142) and in Cilliers (2014:125-142). See also the discussion on 'silence' in Chapter 3.

Lubbe (1993:146).

Cf. Koopman (2002:237-247).

See the discussion on 'silence' in Chapter 3.
} 
complementarity. We should celebrate our diversity; we should exult in our differences as making not for separation and alienation but for their glorious opposites. The law of our being is to live in solidarity, friendship, helpfulness, unselfishness, interdependence, and complementarity, as sisters and brothers in one family, the human family, God's family. Anything else, as we have experienced, is disaster ... Our survival as a species will depend not on unbridled power lacking moral direction, or on eliminating those who are different and seeking only those who think and speak and behave and look like ourselves ... There is room for everyone; there is room for every culture, race, language, and point of view. ${ }^{94}$

Could one find a starker contrast than between the time of apartheid, and this utterance of Tutu? The one separates; the other celebrates. The one fights against the exposure to the so-called 'enemy'; the other stands in awe of our diversity. The one divides; the other is amazed. ${ }^{95}$ It is on these grounds - the interdependence of human beings, as envisioned by his Ubuntu-theology - that Tutu bases his ethical appeals. This represents an ethics not of fear for the enemy, but rather acceptance, but even stronger than that, 'an ethics of celebration' of the so-called 'other'. Fear does not transform anybody, at least not fundamentally, and not in the long run; awe and celebration invite one into a world that is not threatening. This mode of ethics is no whip, chasing people into an enclosure; rather, it is a beckoning hand. It indicates a world, an alternative, of which one could voluntarily say: this is where I want to be; in this space I long to live. ${ }^{96}$ This is indeed a world, not where strict and smothering rules dictate life, rather celebratory freedom, underpinned by an ethics of improvisation. ${ }^{97}$

\section{Timing (as) anticipation}

According to many commentators, the South African 'rainbow nation' is losing its kaleidoscopic charm. Many are lamenting the demise of many aspects of the era that was so boldly inaugurated by Nelson Mandela and others. Some of these sighs express a longing for the 'good old days' of apartheid, but others, like Desmond Tutu, are lamenting what has gone wrong, without giving up the hope of an alternative future. In a speech, delivered in 2006, and entitled,

\footnotetext{
Tutu (2011:50-52).

See again the discussion on 'apartheid sermons' in Chapter 3.

See Cilliers (2017).

See the discussion on 'the ethics of improvisation' in Chapter 2.
} 
What has happened to You, South Africa? Tutu states his sadness concerning certain events in our country. ${ }^{98}$ He laments and sighs - in protest:

My naiveté was that I believed that these noble attitudes and exalted ideals (of the liberation struggle, JC) would, come liberation, be automatically transferred to hold sway in the new dispensation. We South Africans were a special breed, and I believed we would show the world, hag-ridden especially in Africa by the scourge of corruption, that we were a cut above the hoi polloi. Wow! What a comprehensive let-down - no sooner had we begun to walk the corridors of power than we seemed to make up for lost time ... The trouble with these people in government is that they've got power now and they believe that they're going to have power forever, and you have to keep warning them. The Afrikaner Nationalists thought they were invincible. Let me tell this ANC government what I told the Afrikaner Nationalist government: You may have power now, but you're not God. Remember: you're not God, and one day, you'll get your comeuppance. ${ }^{99}$

Desmond Tutu often uses the exclamation Wow! mostly to express his amazement at something good. Here he uses it as an expression of disbelief: how can this be? It signifies the tension between sighing and yearning for a better future. In fact, longing for a better South Africa, yearning for the alternative, has always been part and parcel of Tutu's ethical thinking. Speaking to a white audience in 1978, he declares:

Come, let us walk tall together into the wonderful future that can be ours, black and white together, a wonderful future for our children, black and white together. ${ }^{100}$

98 In this speech, Tutu openly spoke about his dismay that someone like Jacob Zuma could be elected as President of South Africa. Although retired, Tutu still exposes injustices in society, whatever form it takes on. He once stated: "I do not do it because I like to do it ... I cannot help it when I see injustice. I cannot keep quiet ..." In recent times he has spoken out against the massacre of mine workers by police at Marikana, the waste of almost 250 million Rand in so-called 'security upgrades' being done at (ex) president Jacob Zuma's private residence at Nkandla, and in particular the plight of abused women and children, and the fragmentation of family life in South African society. Tutu (1983, xiii). In a recent appearance on national television, he even said: "Be aware. We will start praying for the downfall of the ANC ..." The paradoxes of the past, and the paradoxes of the present, still plaguing our country, perplexes Tutu. He protested against the 'God-with-us' theology of the apartheid era, and he protests against the 'God-with-us' theology of the current ANC Government, from whom we often hear statements like: 'God was there at the inception of the ANC - therefore it is the only Party to vote for'; 'If you vote for any other Party than the ANC, you will go to hell (sic)'; 'If you vote for the ANC, it is your ticket to heaven'; 'The ANC will rule until Jesus comes again ...'; and so on. 
This phrase: 'black and white together', in fact could be called a key rhetorical technique used by Tutu in numerous sermons and speeches. It underlines what I said earlier about the connections between anticipation, and our views on time. ${ }^{101}$ It describes the content of the future Tutu was, and to a large extent still is, longing for. It expresses his anticipation of an alternative, in the present. If it is indeed the task of the church 'to show the world where her future lies', as Geoffrey Wainwright insists, this is what Tutu keeps on doing. ${ }^{102}$

Not everybody agrees with the ways in which Tutu has been expressing his anticipation of an alternative future for South Africa - not during the time of apartheid, and surely not now. Tutu was once called 'Public Enemy Number One', and blatantly accused of being 'on a wicked path. ${ }^{103}$ In some political cartoons of the day, Tutu was betrayed as a devilish figure, complete with trident, tail, and horns, or as a vulture sitting in a tree. ${ }^{104}$ Tutu is also not popular within certain sectors of the ANC government of today, often openly criticising people like the now ex-President Jacob Zuma, and former Finance Minister Trevor Manuel, to name but a few. ${ }^{105}$ He has been stereotyped and shamed by the apartheid government of the past, and he is still being stereotyped and shamed by many members of the present ANC government. ${ }^{106}$

The remarkable thing is that he mostly reacts in a mischievous way, using rhetorical techniques like irony, indirect speech, parody, and lampooning to state his convictions and envisage alternatives, much like the so-called fools of all ages and cultures. ${ }^{107} \mathrm{He}$ could indeed be called a 'rabble-rouser', as his authorised biography states. ${ }^{108} \mathrm{He}$ often makes serious situations relative by means of humour, acting as a type of clown or court jester or joker. In the process, he does not take himself too seriously. ${ }^{109}$

In my opinion, this behaviour of Tutu signifies a remarkable 'playful mode of anticipation. Tutu yearns for the future, but he does this not only through

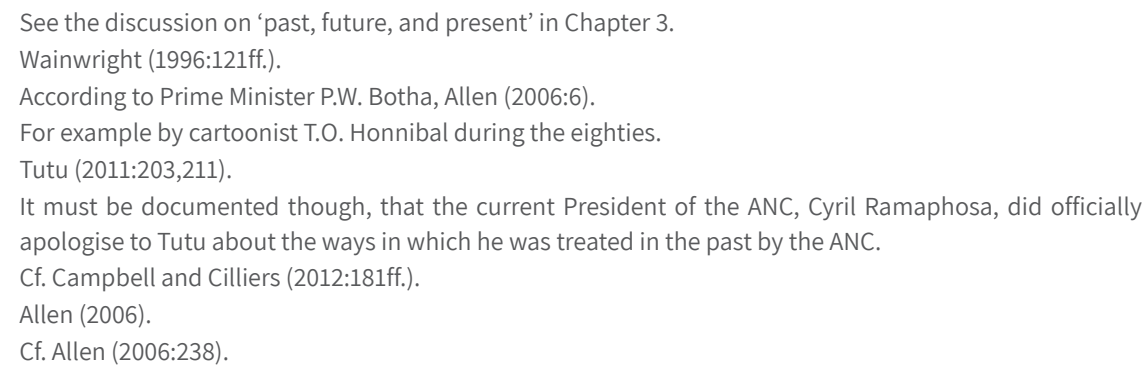


expressions of indignation and anger, but also in a playful manner. He laughs as much as he weeps - for a better future. ${ }^{110}$

It is no wonder that Tutu often links the future to children. "When we see the face of a child," he says, "we think of the future. We think of their dreams about what they might become, and what they might accomplish." ${ }^{111}$ For him, the future is tomorrow's child - to borrow a phrase from Rubem Alves. For him, as for Alves, to hope is to hear the melody of this future. Faith is to dance it. ${ }^{112}$

In a playful manner, children imagine and anticipate an alternative world. To be a child is to play. Through their play, children call for new paradigms, and surprising re-configurations - without them knowing it. (Children are masters of improvisation. $)^{113}$ Through their play, they breathe new life into archaic forms; lifting and shifting that which seems immobilised and immoveable. Or, again in Tutu's words: "Children are a wonderful gift. They have an extraordinary capacity to see into the heart of things and to expose sham and humbug for what they are." 114

Play imaginatively creates its own times and spaces and rhythms, in which the normal order of things is no longer applicable. The playful exuberance of children reminds us of the dawning of the new age amid the old and calls upon us to act accordingly. The future breaks into the present, into the 'now' Again, this type of anticipatory ethics is no whip or threat, but invitation to step out of the sham and humbug of old patterns, into the imaginative space of new possibilities. Tutu imagines, no, rather 'playfully re-imagines' a new society, build on the vision of God's alternative. In the words of Patrick Miller, Tutu's sermons are filled 'with imagining a different way, with envisioning and announcing the new possibility of God's way in the world ...'115

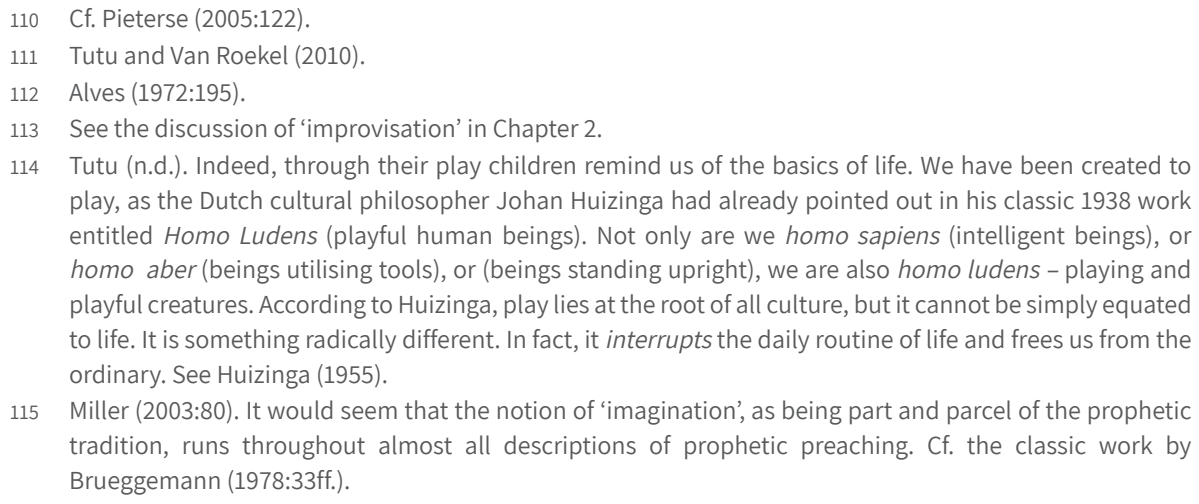
play, as the Dutch cultural philosopher Johan Huizinga had already pointed out in his classic 1938 work entitled Homo Ludens (playful human beings). Not only are we homo sapiens (intelligent beings), or homo aber (beings utilising tools), or (beings standing upright), we are also homo ludens - playing and playful creatures. According to Huizinga, play lies at the root of all culture, but it cannot be simply equated to life. It is something radically different. In fact, it interrupts the daily routine of life and frees us from the ordinary. See Huizinga (1955).

115 Miller (2003:80). It would seem that the notion of 'imagination', as being part and parcel of the prophetic tradition, runs throughout almost all descriptions of prophetic preaching. Cf. the classic work by Brueggemann (1978:33ff.). 
Play is not about production, not about an ethics of achievement, but about joy. For playing children, time is not money. To be able to play, one needs imagination. Imaginative play implies a radical critique of a society that opts only for productivity and success, often sacrificing the joy of imagination. Play stretches the imagination, opening possibilities unsought and unthought of. It asks, 'What if ...?'116

Children somehow sense that the gift of tomorrow is a gift of grace to be celebrated today. As a matter of fact, another word for play is 'grace'. Playing children are keepers and guardians of grace. They sense another world. ${ }^{117}$

But perhaps this imaginative anticipation of an alternative society, this 'ethics of anticipation of, and seeing the future through the face of a playing child' is again best depicted aesthetically, as we have often discovered in this book. An example of this comes, strangely enough, in the form of a classic film, produced in South Africa in 1976 - completely against the grain of the apartheid ethos of the time. The film was entitled, e'Lollipop, sometimes also advertised as Forever Young, Forever Free, and is basically about the friendship between a black boy and a white boy, in a time when black and white were not supposed to mix. In this sense, the film truly 'interrupted' the apartheid times.

The two children - Tsepo (Muntu Ndebele) and his orphaned friend Jannie (Norman Knox) meet when Jannie's parents die tragically in a car crash in the Lesotho Mountains. Jannie is sent to a missionary station in Tsepo's village where they become best friends. Together with their dog Sugarball, life is full of childhood fun and antics until tragedy strikes again: Jannie, aged 13, is seriously injured when one of their games goes horribly wrong. Tsepo and his community pull together so that Jannie can receive emergency medical treatment.

116 This reminds one of Walter Brueggemann, when he talks about the role of the Old Testament prophets in their passion for justice, namely 'judgement', 'pathos', and 'new beginnings'. Brueggemann uses these terms against the backdrop of the experience of exile in Israel, a state of transition in which the plight of the marginalised in Israel were often only articulated by the prophets, while issues like displacement and loss were not on the horizon of those in power. This experience of liminality, of being in-between, asked for a specific form of prophecy, namely one "... that witness to the terrific loss that comes on the community, what in prophetic parlance is 'judgement', but judgement communicated with more sadness than rage ... that testify to the 'pathos' of God, to the pathologies of human community that contribute directly to God's own pain, a pain that reaches an extremity on the cross ... that find around the edges of failure 'new beginning', new social possibilities that are given here and there in the midst of the deathliness as the 'prophets watch for and discern signs of newness.'” Brueggemann (2003:74). 
e'Lollipop is a true South African classic of international stature that transcended the apartheid boundaries of its day. Despite the fear, hatred and brutality that plagued South Africa in the mid-1970s, e'Lollipop told a story of friendship and commitment that confronted apartheid South Africa with images of two children, black and white, playing together. Pictures like the following spoke more than a thousand (ethical) sermons. It angered those in power to such an extent, that the film barely escaped being banned.

In my imagination, I can hear Desmond Tutu not only chuckling, but laughing out loud - wishing he could be part of the play - his Anglican regalia flapping in the wind, not unlike Tsepo's blanket ...

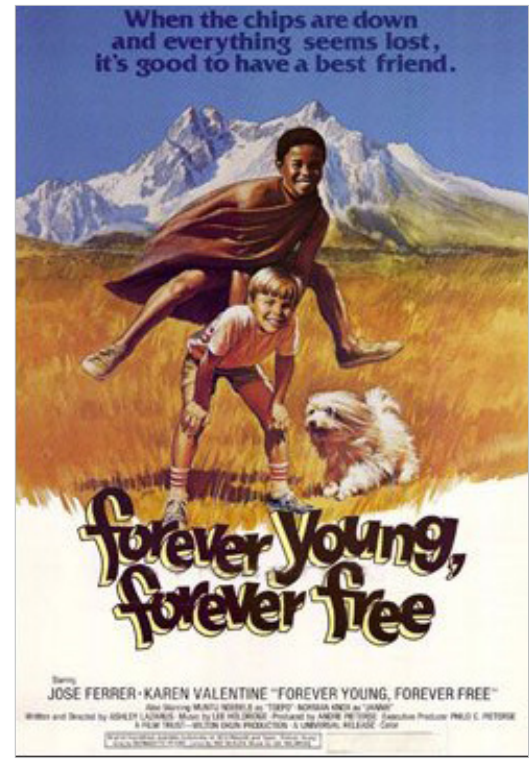

Figure 4.3 The movie poster of e'Lollipop (Forever young, forever free) 1975 (IMDb)

Somehow, the film acted as a type of imaginative alternative, indeed a proleptic fulfilment of Desmond Tutu's longing for a South Africa in which black and white together, could play as children. For many South Africans living in the seventies, this would have been unthinkable. For many, even today, it still is.

Imagine this: black and white, playing together, 'now' ...

Wow! 


\section{Beyers Naudé: an ethical mode of moral discourse}

While Allan Boesak fills up the 'now' in his sermon with the seriousness of the Church and the devotion of Christians in South Africa, Desmond Tutu opts for portraying the future-as-present in the form of playing children, black and white together. Beyers Naudé adds to the richness of these prophetic voices, by emphasising the priorities of the present, 'now', as the urgent need to 'interrupt structural injustice, in view of restructuring justice in South Africa. ${ }^{118}$ In order for us to understand this emphasis, we need to take cognisance of, albeit partially, where Beyers Naudé was coming from.

The history and legacy of Beyers Naudé (also affectionately known as 'Oom Bey') has been well documented, and need not be repeated at length here. ${ }^{119}$ In broad strokes it could be said that Beyers Naudé grew up in a home where patriotism was the order of the day, and he was identified at an early age as a possible leader in the Afrikaner community. ${ }^{120} \mathrm{He}$ studied theology at Stellenbosch University (1932-1937), and served on several student councils, often as chairperson. In due time he became a member of the then powerful and elitist Afrikaner institution called Die Broederbond, and Moderator of the Southern Transvaal Dutch Reformed Synod. In short: Naudé was positioned to play a leading role in Afrikaner culture.

All of this however changed when Naudé felt his conscience being stirred by what was happening during the time of apartheid, particularly the massacre at Sharpeville (21 $1^{\text {st }}$ of March 1960) resulting in a decisive, and for many, shocking and dramatic breakaway from powerful Afrikaner circles, and identifying with the ideals of the political struggle against apartheid. ${ }^{121}$ Naudé consequently felt compelled to resign as minister from the Dutch Reformed Congregation of Aasvoëlkop in Johannesburg, delivering a moving farewell sermon there on Sunday 22 September 1963, after much inner struggle. ${ }^{122}$

Some scholars point out that this fundamental decision by Beyers Naudé to practise his theology from within the paradigm of the 'option for the poor'

\footnotetext{
118 As stated already, these distinctions are not watertight - all three preachers would, for instance, preach about structural injustice.

119 The legacy of Naudé is discussed in for instance Hansen (2005); Hansen and Vosloo (2006); etc. What follows, is a revised edition of Cilliers (2018).

120 Naudé (2013:vii)

121 "Dr Beyers Naudé would be a good example of someone who could be said to have taken this option for the poor and suffered the consequences ...” Nolan (1985:189).

122 Naudé (1995:68).
} 
ultimately represents a shift away from a race struggle to a class struggle. ${ }^{123}$ It is in the light of this shift that someone like Boudewijn Sjollema, former Director of the World Council of Churches' Programme against Racism, could say that Naudé was in fact a global prophet, having an impact far beyond the borders of South Africa: "Beyond, beyond - absolutely! ... In that sense Beyers was surpassing, was bypassing the national South African context and was going far beyond. I think that is how the ecumenical movement will recognise him, or ought to recognise him in so far as it hasn't happened."124

As a result of his moral choice against apartheid, Naudé was treated as a persona non grata by the powers that be, jailed and placed under house arrest. In fact, his previous seemingly powerful position within the Afrikaner community was completely inverted - he became a figure of resentment (often called a 'traitor'), and was alienated, branded as a collaborator with the 'enemy'. During this time, he never gave up hope for the achievement of a 'new South Africa', where justice would prevail, as frequently repeated in his autobiography, My Land van Hoop (My Land of Hope). ${ }^{125}$

In the process, Naudé bravely swam against the ethos of fear that permeated a large portion of the Afrikaner community. In his own words: "I would like to mention in explaining the Afrikaner's traditional attitude to race is 'fear' ... for the ordinary Afrikaner his traditional enemy always had a black face or included one - and it is this fear which determined so much of his attitude and policy towards his non-white neighbour in this country."126

Beyers Naudé has rightly been hailed as an icon in the struggle against apartheid. ${ }^{127}$ He was of course not the only one - joining the ranks, as I said earlier, of people like Archbishop Desmond Tutu and Allan Boesak. ${ }^{128}$ When we keep the distinctions made by Gustafson regarding the different modes of ethical discourse in mind, referred to above, we could say that Naudé falls within the category of an 'ethical or technical mode of moral discourse'. In this mode precise distinctions and logic, also in explaining the consequences of core concepts like justice and the articulation of the rational grounds for ethical values shared by believers and non-believers, are typical features. Openness for

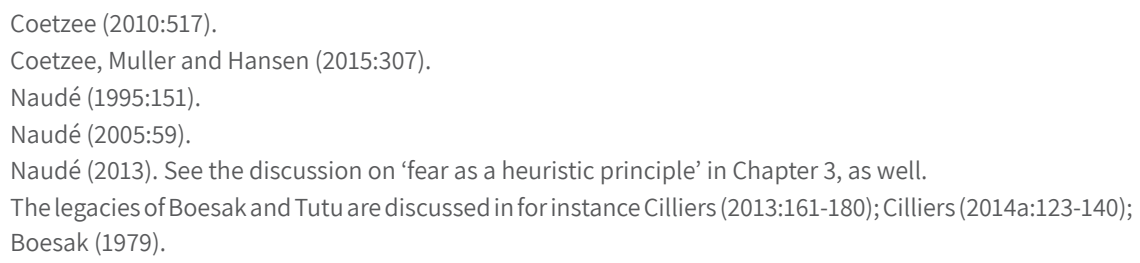


dialogue is furthermore a fundamental characteristic of this mode of moral discourse - all distinct elements of Naudé's preaching.

His sermons could probably not be described as rhetorical masterpieces, perhaps rather as brief and often to the point, in accordance with his logical style of presentation, through which he repeatedly calls for (ecumenical) dialogue. Many of his sermons are only available to us as sketches - outlining that which was of importance for him. ${ }^{129}$ In what follows I limit myself to two of these sermon outlines, particularly in terms of their articulation of Naudés convictions concerning justice - for him the priority of the hour - and allowing as much of his own voice as possible to be heard.

\section{"Poverty and Privilege"}

In a short sermon entitled, Poverty and Privilege, preached at the Dutch Reformed Church in Africa in Pretoria on 9 February 1992 - about two years before the first democratic elections took place in South Africa - Naudé refers to the 'astoundingly large number of references in Scriptures to the poor, the widow, the hungry, the foreigner .., and confirms his belief that God calls the church to stand in solidarity with these marginalised people. ${ }^{130}$ And, true to his logical style of pointing out consequences, he makes four points, in concreto, about what this would entail for the church(es) in South Africa:

» Poverty and injustice normally go together. They are not synonymous, but often they are like twin horses pulling the cart of the affluent and the privileged.

» Scripture does not provide a specific economical system for solving the issue of poverty, but it does judge and calls upon the church to judge all economic systems in measuring them against the biblical demands of justice, love and mercy for all God's creatures.

»As far as South Africa is concerned, the policy of apartheid has been one of the main causes of the economic injustice, which over many decades have been inflicted on millions, especially of our black (African) community. God therefore demands that all those Christians who have been involved and have approved in principle and practice the injustice of apartheid 
should admit their wrongdoing in this regard and prove their sincerity through some form of restitution.

» This congregation will be a crucial test to the NGKA and the NGSK (Dutch Reformed Mission Church) as well as the NGK of what God demands of all of us in the new South Africa. He will judge all these churches, not only by our words and resolutions but especially by our deeds and actions. ${ }^{131}$

It is clear that Naudé views the congregation highly, through a 'theological lens', by stating at the beginning of his sermon: "This is a ... unique congregation," and ending off by stating: "It is also possible that God may use this congregation as a test and a stimulus to prove the need for a united Reformed family where love, justice and mercy may be the hallmarks." ${ }^{132}$ Naudé sees the congregation (church) as playing a fundamental role in the confession of injustice, but also in the restructuring of justice. In fact, the whole issue of structural injustice ${ }^{133}$ and restructuring of justice forms the background of the four points quoted above.

For Naudé, justice is not only a private matter, but structural, and furthermore contextual, and he challenges his congregation (in effect the whole Dutch Reformed Family) to not only speak out, but also to strive to contextually transform structures that could either hamper or foster justice, by means of the power of ideas, values, transformed relationships, and communication, 'not only by our words and resolutions but especially by our deeds and actions. This seems to be a golden thread running throughout Naudés preaching, namely the call for 'structural and contextual justice.' Naudés preaching could, in my opinion, indeed be described as a structural-contextual-ethical mode of moral discourse.

\section{"Priorities at the present moment"}

In a sermon preached on 13 April 1997 at the launch of the Gauteng Provincial Council of Churches, almost three years after the dawn of the new democracy in South Africa, Beyers Naudé articulates his deep concerns about certain disturbing events in the new South Africa:

Many South Africans ... experience these changes as a time of confusion, lack of clarity and direction, especially where increasing criminal violence, serious abuse of women, conflict in many educational institutions, chaos in some state hospitals, shocking revelations about fraud and corruption,

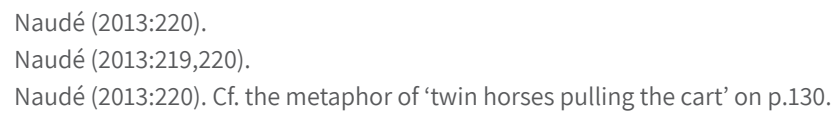


all tend to strengthen the impression that our country is slowly moving towards a state of anarchy. Our newspapers, our radios, our televisions are full of reports about bank robberies, police killings, car hijackings, mugging of people amidst rising unemployment and the hopelessness of thousands of people. ${ }^{134}$

The ongoing relevance of these words uttered twenty-two years ago, is perhaps more evident today than ever before. Sensing the urgency of the situation, Naudé asks the Gauteng Provincial Council of Churches; 'What should be your priorities at the present moment?', and again spells out the logical consequences and challenges of this for the churches in a few brief, even terse points:

1. Strengthening of the ecumenical witness;

2. To further, wherever possible, the goal of Christian unity;

3. To confront the serious economic needs of much of our people: poverty, unemployment, homelessness and the evils that flow from such poverty, unemployment and homelessness we find in a concentrated way in Gauteng;

4. To challenge increasing fraud, corruption and self-enrichment in our community; and

5. Spirituality. ${ }^{135}$

Again, the contextual and structural dimensions of Naudé's understanding of justice and injustice - 'and the evils that flow from such poverty' - can clearly be discerned, and many other post-apartheid sermons of Naudé could be quoted in this regard. ${ }^{136}$ The consistency in Naudé's preaching before and after the demise of apartheid is evident; the golden thread of a structural-contextual-ethical mode of moral discourse connects these epochs of his prophetical witness. ${ }^{137}$ It is therefore not surprising that in this post-apartheid sermon we again hear the call to the (ecumenical, united) church to contextually address ('confront ... challenge') those structures that threaten justice. In effect, Naudé consistently kept on asking: 'how long must the systemic injustice still be tolerated, even actively kept intact?' In my opinion, it remains an open question

Naudé (2013:237).

Naudé (2013:237-238).

136 For example in a sermon preached in Alexandra on 20 October 1996: "There are many good and positive things which have been established and of which we should constantly remind ourselves. But it is also true that there are things happening that deeply worry us ..." Naudé then refers to a variety of societal-structural problems like corruption, the 'gravy train', etc. Naudé (2013:233).

137 This is not to say that Naudé did not undergo changes of conviction. For a discussion on 'the different phases of his theological development', cf. Coetzee (2010:592). 
to what extent these churches and the Dutch Reformed Church in particular, have in fact acted upon this challenge.

\section{Restorative justice or tragicomedy?}

Obviously, different churches and theologians in South Africa have all contributed in many ways to the dawn of the new South Africa, being instrumental in the formation of new and meaningful theological paradigms. ${ }^{138}$ The fact that glaring economic inequalities between poverty and privilege lie at the root of many of South Africa's societal problems, and the view that the church should urgently take part in this debate, have been acknowledged many times before. ${ }^{139}$ In essence, what is needed is a theological paradigm that does not shrink from this debate, but rather helps to set the agenda and provide relevant content. ${ }^{140}$

It is, however, not easy to describe this (new) paradigm. It has, for instance, been called a theology of reconstruction, as opposed to the paradigm of liberation theology. ${ }^{141}$ According to Mugambi the period of political liberation, with its concomitant liberation theologies, should now be complemented by a theology of reconstruction, in which the issue of 'systemic poverty' is tackled head-on. ${ }^{142}$

This theology of reconstruction, however, is not an elitist enterprise - it encompasses, and is nurtured within, the community. ${ }^{143}$ The 'pedagogic of reconstruction' is aimed at harnessing the energies and resources of the communities in a collaborative effort to rebuild society. It takes a hard look at the 'root causes' of injustice, especially also in its economic and systemic modes of appearance. ${ }^{144}$ In short, a theology of reconstruction demands a new form of discourse, which is in principle open to other disciplines and strives to address the issue of poverty within a different paradigm than just alleviation through 'compassionate handouts.' ${ }^{45}$

\footnotetext{
38 What follows is an excerpt from Cilliers (2011:187-198).

Cf. Smit (1984:71).

According to Finca (2007:4).

Villa-Vicencio (1998:2ff.).

According to Mugambi, liberation and reconstruction represent different socio-political processes within specific cultural contexts, requiring different theological paradigms. Mugambi (2003:61).

Mugambi (2003:74). See the discussion on 'community' in Chapter 7.

The challenge is therefore not to return to old modes of doing theology, but to work with all relevant partners in constructing an innovative theology that builds on the humanity and dignity of life. Elliot (1987:181-182). Cf. Villa-Vicencio (1998:2).

145 Swart (2004:328-339).
} 
Other authors, such as Maluleke, prefer to talk about a theology of restitution, especially in the light of the fact that the notion of restorative justice can be misunderstood, misappropriated and softened. ${ }^{146}$ It is furthermore important to understand that a theology of restitution should not be confused with charitable acts. ${ }^{147}$

Swart takes this further and states that the South African churches, like their NGO counterparts in post-apartheid South Africa, are faced with the challenge to move beyond conventional welfare and local project-centred modes of intervention in poverty, towards more sophisticated modes of development intervention, in other words to look beyond the individual community and seek changes in specific policies and institutions at local and national levels ${ }^{\text {, }}{ }^{148}$ In this regard churches as faith communities can play an important role because of their 'politics of ideas', i.e. to contribute towards 'change to be brought about by the power of ideas, values, transformed relationships, and communication., ${ }^{149}$ In this way restitution can become a truly people-orientated movement, not only towards 'poor people', but also as a double movement 'in which the imperative of renewal, conversion, and change should as much be directed to the life-worlds of the economically rich and privileged.' ${ }^{150}$

Whatever route one chooses to follow, it should indeed be all about 'reconciliation restoring justice', or in the words of De Gruchy: “... to recover the full meaning and rich texture of reconciliation, and to demonstrate its inseparable connection with the restoration of justice." ${ }^{151}$

\footnotetext{
146 Swart (2008:104-149).

147 Maluleke (2008:681-696).

148 Swart $(2008: 123,126)$.

149 Swart (2008:128).

150 Swart (2008:134). It is of course impossible to talk about restorative justice in South Africa without also touching upon the issue of 'land restitution' - recently again emotionally debated in parliament and the media. This remains a sensitive and complex challenge. There are many theories underlying the modus operandi of land restitution, for instance, the so-called special-right-based (SR-based) argument for private property, which justifies private property as being necessary for the protection of property rights that have been legitimately acquired by, or transferred to, the holder. The general-right-based (GR-based) approach, in contrast, justifies private property as essential to the development of individual freedom. The South African endeavour to restore land ownership leans strongly towards the principle of rectification of injustice, which permits state interference to re-legitimise the property rights order. Roux suggests that we revisit the notion of land restitution by removing the artificial time limit imposed on the finalisation of the land restitution process; by brokering deeper and more meaningful settlements; by involving current landowners in the search for settlement solutions (in other words: by bringing people together in safe spaces for negotiation and collaboration); by investing more resources in monuments and museums (thus rekindling remembrance); and by calling for an apology from white South Africans for apartheid forced removals, therefore re-inviting reconciliation into the process. Roux (2008:147,168-171). 
The Reformed Family of Churches has also been struggling with the issue of restorative justice. One of the relatively recent developments within the Reformed Church Family in South Africa has been a rediscovery of the so-called 'missional church'. It is not possible to do justice to the history and development of this movement within the limitations of a book like this. A few broad strokes must therefore suffice: the original intention of this movement was 'highly contextual', striving to answer the question: what does the Gospel mean for this specific context ('culture network') within which we find ourselves - a culture in which the Gospel has been effectively domesticated? ${ }^{152}$

Willem Saayman makes the point that although there are no significant terminological differences between 'missional' and 'missionary' - “... as an Afrikaans proverb says, choosing six of the one and half a dozen of the other ..." - the concept missional was not originally chosen simply to function as a synonym for missionary, but is rather part of a thoroughly contextual North Atlantic or Western missiology. ${ }^{153}$ The context of the missional movement (also the context against which it reacts) is therefore the phenomenon of so-called 'emerging churches' within postmodern settings. ${ }^{154}$

This contextual thrust can be seen in the works of the founders of the movement, in particular in the classic works of Lesslie Newbigin and George Hunsberger, who contributed fundamentally to the question about the relationship between the Gospel and our Culture Network. ${ }^{155}$ Exponents like Darrel Guder (working in the Gospel and our Culture Project) have popularised the idea of a missional church, particularly in North America - a project not necessarily acclaimed positively by everyone. ${ }^{156}$ According to Willem Saayman, the main concern of this project 'is a desire to bring the World Council of Churches' discussions of missio Dei ('the mission of God') and Lesslie Newbigin's missionary insights to bear on North America.' ${ }^{157}$ As a matter of fact, it has even been called a 'Trojan horse through which the (unassimilated) 'American' vision was fetched into the well-guarded walls of the ecumenical theology of mission., ${ }^{\text {, } 58}$

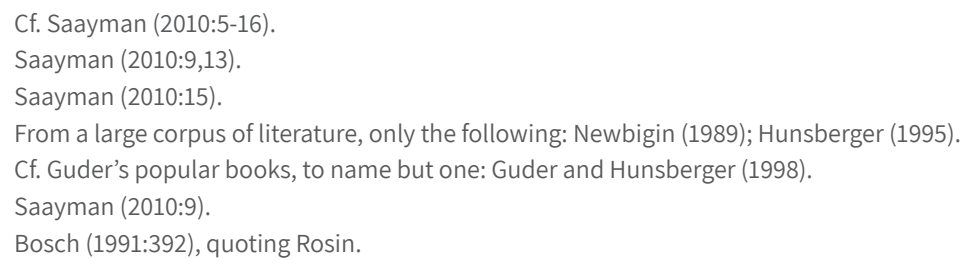


It is therefore a legitimate question whether the missional paradigm could be transplanted to South Africa, 'lock, stock and barrel without any further ado.' ${ }^{159}$ Saayman pertinently asks whether the exchange of these two terms (missional for missionary) is not simply an effort to 'rebrand' the latter, which has fallen into (anti-colonial) dispute? Furthermore, he states:

The definitive question is: is that what we really want to do? Is that what we really need to do to overcome our problem? ... If we choose for 'missional', we unavoidably choose now for emerging churches in postmodern contexts. How useful is such a choice for the theological discourse in the Third World in general and Africa in particular? ... We will have to re-indigenise or re-contextualise the concept to make it useful. ${ }^{160}$

It is interesting to note that when the renowned South African missiologist, David Bosch, posed the question as to what mission means in South Africa, he was in line with the original intention of the movement, namely, to translate the Gospel in terms of contextual issues, but then indeed strongly (re)indigenised and (re)contextualised. In his magnum opus he wrote movingly on 'mission as contextualisation,' 'mission as quest for justice,' 'mission as liberation', etc. ${ }^{161}$ One could perhaps state that his whole theology hinges on the commitment to transform the plight of the poor and marginalised, taking his cues from orthopraxis, not orthodoxy. ${ }^{162}$ As a matter of fact, a whole book has been written on, and dedicated to this praxis of Bosch's missiology, which is said to be 'unmistakably and consciously contextual', and addresses issues like racism, nationalism, economics, gender, etc. ${ }^{163}$

The notion of a missional church has also been widely debated within the Dutch Reformed Church, with many articles, conferences and Synodic declarations resulting from this endeavour. In the official Synodic report, entitled Framework Document on the Missional Nature and Calling of the Dutch Reformed Church, ${ }^{164}$ the emphasis falls on the word 'new' - new thinking about God, the Incarnation, the Kingdom of God, the world, the church, the offices in the church, the formation of faith in the church, the liturgy, the theological training, etc. In short, just about every item that could be connected to the

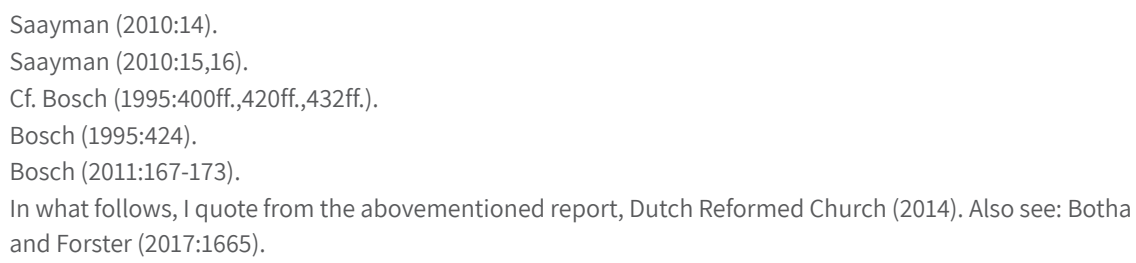


church and theology is seen through the lens of being 'new'. One could in fact say that the notion of a missional church in effect becomes a type of 'container concept' that is set up to carry all that is 'new'. In the process, inspiring and creative theological frameworks are drawn up, which are to be commended.

Although the document starts out by referring to the challenges facing the Dutch Reformed Church 'within the South African context', the few, general comments made on the calling to be missional within specific contexts, i.e. practising 'public theology' within a new understanding of the 'world', in my opinion begs for further explication. ${ }^{165}$ Although the document explicitly states that it 'does not spend time on the development of comprehensive practical steps - it is for each congregation to create its own ${ }^{166}$, and although one surely should not judge a movement on the grounds of a single document, this official document in my opinion still lacks a specific analysis of urgently relevant issues in the current South African context, issues directly related to structural injustices that still prevail, even twenty five years after apartheid. Although there are a few direct references to South Africa ${ }^{167}$, this document could as well have originated in North America, or any other country, for that matter. ${ }^{168}$

Are we missing the point? Or, in terms of the terminology of this book: are we (again) mistiming grace - in contrast to the preaching of, for instance, someone like Beyers Naudé We might not be the first people to do so. The Netherlands

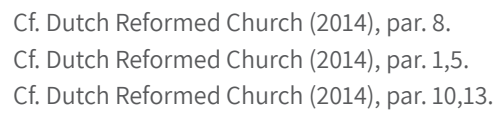
missio dei, for missio dei. Cf. Bohren (1962:4). Perhaps this lack of contextual analysis could be traced back to the way in which Calvin has been interpreted within the Dutch Reformed tradition in South Africa. It has been noted by some scholars that this interpretation, while being solid in soteriological content, indeed lacks a 'mature theology of creation'. Perhaps the lack of a mature theology of creation can indeed be attributed to a dominant, and often exclusive theological focus on 'ecclesiology' in ministerial training; the countering of a natural theology associated with apartheid with a strong contrasting emphasis on 'Scripture'; and a narrow 'pietistic notion of salvation' as personal sanctification. As far as the latter is concerned it is well known that the Dutch Reformed Church always had a certain pietistic component in its theological make-up, dating back to the times and undeniable influence of the Scottish ministry in South Africa, the most prominent figure being Andrew Murray. Cf. Conradie (2010:357-369) and Cilliers (2011:279-299). It is, however, important to note that the Scottish influence in South Africa had many faces, distinguishing it from what is often understood under the term pietism. Although there was the puritan dimension in the Scottish tradition, that in effect led to an ethical vacuum as far as social issues were concerned, one could also state with Coetzee that it was in fact this Scottish tradition, with its assertion that all people are equal, that influenced Beyers Naudé, together with his understanding of the so-called Utrecht School, to become more and more critical of the apartheid ideology. Coetzee (2013:1-15). 
has also seen its drive towards a missional church, with concomitant critical voices. Marcel Barnard, for instance, after giving an extensive overview of the countless activities that have been initiated to fuel this drive, of money being invested and personnel being appointed, expresses his misgivings, as follows:

After eight years we have discovered that nothing has come of these ideals. The Protestant Church in the Netherlands consists of spectacularly waning communities ... Particularly in the years that the church claimed a new missional identity, she did not even come close to retain her dwindling numbers. The missional project has failed, or we should give a different meaning to the word 'missional' ... Against the backdrop of the waning church, missional language and pretences have become laughable. We are playing in a tragicomedy ... Let us agree that from now on we will no longer be 'missional'. We call a halt to the missional activism. We rather return to the inner chamber. The inky night. The void. The great silence. The judgement of God. There, not visible to any outsider, we bend over the Scriptures and search whether we may not again, perhaps softly, hear the foolish voice of the Gospel ... Here we gather around a table and share a tiny piece of bread and take a tiny sip of wine. And then we say (and we believe it ourselves): This is a sign of the great feast of all nations, with the best food and the best wines. And we inconspicuously walk an extra mile with those who need it - the refugee, the vulnerable elderly, and the abused child. Maybe a few people might ask themselves: what is it with those Christians? Then we will have little to say. Perhaps stutter: 'You know, we belong to an executed criminal, crudely hung up on a piece of wood.' That is it. Let us simply be. Our God works in secret. That is His mission. ${ }^{169}$

\section{Between silence and struggle}

Speaking from his context, Barnard calls upon the churches in the Netherlands to bring a halt to the missional activism; to rather go back into the silence of the void, even into the judgement of God. From his context, Beyers Naudé calls upon the churches to step out of the silence of the void, in order to grapple with the realities of structural injustices in South Africa - a call which many may experience as highly interruptive. ${ }^{170}$ Perhaps our calling lies somewhere in between the 'ethical tension of silence and struggle'; of going back to the sources of our identity - being followers of an executed Criminal - and going

169 Translated and paraphrased from Dutch by Johan Cilliers, Barnard (2013:34).

170 See the discussion on 'silence' in Chapter 3. 
out (whether missional or missionary does not really matter) into the realities of South African societal structures.

Perhaps our ethical 'priorities at the moment' are constituted by two movements. First, a 'centripetal movement', back to the poor and marginalised, to the preferential option for the poor; back to the orthopraxis of listening to the poor and allowing our theology to be formed within their spaces, following in the footsteps of Beyers Naudé and David Bosch and others like them. It is here, within the present and presence of the poor and vulnerable, that the real present and presence of God (praesentia realis dei) can be experienced. Second, a 'centrifugal' movement, against the grain of our fear for the 'other', into the hard realities of injustices in everyday life in South Africa, and against the grain of all structures that lie at the root of these injustices.

How exactly we are to go about this ethical calling will be an ongoing debate, hopefully in the form of an open dialogue. In this regard, the life and sermons of Beyers Naudé still challenge us to revisit the role that religious communities 'can' play within the South African context. His passion for justice and his structural-contextual-ethical mode of moral discourse remind us that religion 'can' in fact contribute towards political processes. His legacy calls upon people - also religious people - to develop stronger bonds with their political systems, hopefully resulting in the (public) re-shaping of a just society. ${ }^{171}$

In my opinion, Beyers Naudé made a sterling contribution towards the restoration of justice in South Africa. He understood the space (context; situation), and he timed the possibilities (of justice, and grace):

South Africa is a microcosm of the contemporary world. Here white and black, East and West, rich developed First World and poor developing Third World meet as in no other country in the world: this sets a tremendous challenge, but it is also a unique privilege. In the melting-pot of this meeting Christians who want to live out their faith have an incomparable opportunity to witness to justice, love of neighbour, truth and compassion.

\footnotetext{
We can discern three dimensions when we talk about the concept of politics: 'Polity' in the sense of a formal structuring, which includes questions concerning the order of political systems, its norms, judicial arrangements, institutions, and organisations; 'Policy', which entails the formative and educational processes of politics, inclusive of specific aims and problem-solving mechanisms, understood within a specific framework of values; and 'Politics' as the actual processes of communication of interests, of confrontation with other political systems, and the quest for building consensus within its own ranks. The specific contribution of religion might be linked particularly (but not exclusively) to the notion of 'Policy', in the sense that it can contribute towards the necessary dialogue about, and formation of ideas and values, and acting as a conduit in the search for problem-solving mechanisms, according to Münkler (1997:2).
} 
Indeed, the space is ripe, and the hour is 'now' ...

\section{But, how long is now?}

How long must systemic injustice still be tolerated, even actively kept intact? This is what Beyers Naudé consistently keeps on asking. I have been confronted by a similar question before, in a remarkable setting - standing in front of a mural-graffito in Berlin. It still confronts me, in a rather interruptive manner:

In Berlin, one finds an interesting piece of graffito on one of the walls of the Tacheles, an alternative art centre representing times when artists spoke out fearlessly against political and social divisions (the German word, with Yiddish roots, for speaking outright being 'tacheles'). The graffito asks the question: 'How long is now?' Well, how long 'is' now? Obviously there are many (cultural) answers to this question - as a matter of fact, at a second glance at the graffito one sees that the question actually contains no question mark (?) - as though it is already in the form of a statement, an invitation to experience how long (and rich) 'now' can indeed be. Or, perhaps it represents an existential cry, articulating the unbearableness of the moment: Why can (this specific) time not pass by more quickly? ${ }^{172}$

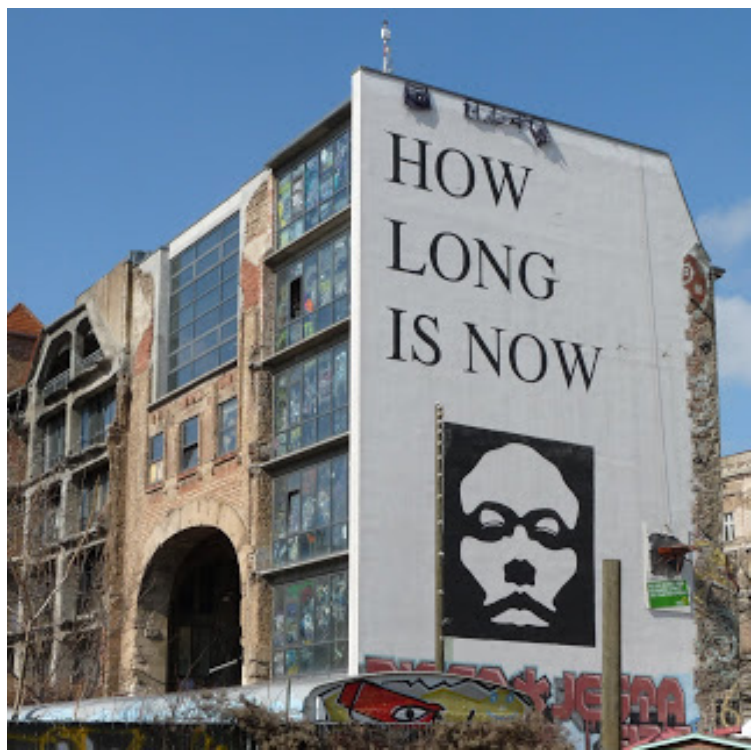

Figure 4.4 An abandoned building in Tacheles, Berlin, with graffiti (Tacheles: How long is now, 2010) (Public Domain) 
'How Long is Now' probably represents 'both' a melancholic sigh of resignation, and a utopian vision. As a 'sigh of lament' it expresses the reality that time consists of a continuum of moments that perish as soon as they are there, and even those fleeting moments often being filled with suffering. As a 'utopian vision', it points towards a (possible) eternal significance of these fleeting moments. In a sense, this iconic graffito expresses the tension between redeemed and unredeemed time, perhaps even the tension between linear and cyclical time that I have been referring to throughout this book. ${ }^{173}$

This reminds one of Walter Benjamin's critique of some understandings of 'history'. Benjamin propagated a radical alternative to the perception of history being a (linear) one-way street, indeed a continuum of empty 'nows.' ${ }^{\text {'174 }}$ The latter view on history is often associated with the so-called philosophy of progress, which advocates a progression towards some form of ideological future. Benjamin rather opts for what he calls the messianic power of 'now', which is enriched through its reaching backwards into the 'past', so redeeming the present of the haunting spectres of the past, unveiling that which was once lost. ${ }^{175}$ According to Benjamin, the linear interpretation of time could indeed be linked to the Christian belief in a telos, called the eschaton. ${ }^{176}$ An overemphasis of this particular focus on time as unending 'process' could then take on a backwards and forward mode of facing infinity, with the result that the individual moments of history are stripped of any existential significance. ${ }^{177}$

Coming back to the question posed by Beyers Naudés sermons: do we not need the 'messianic power of 'now', in order to be liberated from our haunting spectres of the past, still roaming about in South Africa? Must we forever suffer under the structural injustices of apartheid? Do we not need a utopian vision,

173 See the discussion in Chapter 1.

174 Benjamin, Bullock et al. messianic thinking is always linked to a messianic re-conceptualisation of the concept of historical time. Benjamin consistently proposes that no concept of history can be based on a linear, successive, and mechanic time, but only on a non-linear, abbreviated, and condensed time. For him, history is "... the subject of a construction whose site is not homogenous, empty time, but time filled full by now-time [Jetztzeit]”. (Benjamin, Bullock et al. 2003:395).

175 The 'theological' concept for this fully filled, fulfilled time is 'messianic time'. Benjamin, however, constantly uses this theological concept in view of 'political revolution of the status quo of structures'. Herein lies the (theological) messianic link - the disruption (explosion) of linear time, through the power of the messianic 'now'. He states: "What characterises revolutionary classes at their moment of action is the awareness that they are about to make the continuum of history explode." Benjamin, Bullock et al. (2003:395).

176 It is interesting to note that Benjamin in fact also makes use of some New Testament notions of time, for instance Kairos. See Lindroos (1998:43-46).

177 See Benjamin, Bullock et al. (2003:395ff.). 
in the words of Beyers Naudé, 'not only by our words and resolutions but especially by our deeds and actions'?

'Well, how long is now (?)' 


\title{
SERMON: How LONG, LORD?
}

\author{
How long, Lord? Will you forget me forever? \\ PSALM 13:1
}

The worst of the worst that can happen to you. How would you describe it? The biggest tragedy that can overcome you. What would that be? If you think back on your life history, there are surely a number of experiences that could qualify for this doubtful honour: the time you were in a car accident or underwent an operation; perhaps when you had to hear a doctor's diagnosis or received a death notice. What could, for example, possibly be worse than a parent standing at the deathbed of a child? Is death not the totality of all the most dreadful things in life, the gruesome summary of the worst of the worst? Surely, nothing could possibly be worse than death?

It can. There is something even worse than the most grievous things that life can throw at you. In fact, all the grievous things can be merely symptoms, fallout of this greater, all-encompassing misery: When God is silent; when you begin to feel that God is hidden in all the terrible events in your life, that God is concealing Himself in them.

This concealment of God is the worst of all; it is the real worst of the worst. Can there be a greater horror than this: that God, who is the source of life and love and meaning, is hiding His's face from you?

What could be worse than this empty, seemingly never-ending 'now' ...?

Lord, how long must this 'now' be ...?

The poet of Psalm 13 knows exactly what we are talking about. No less than four times he sighs, cries out rhetorically:

How long, Lord? Will you forget me forever?

How long will you hide your face from me?

How long must I wrestle with my thoughts

and day after day have sorrow in my heart?

How long will my enemy triumph over me? ${ }^{\text {178 }}$ 
This is a groan one finds in many of the psalms, particularly the penitential psalms. ${ }^{179}$ It is also heard in several other places in the Bible, particularly in the prophets, for example Habakkuk when he cries out in the same vein: "How long, Lord, must I call for help, but you do not listen? Or cry out to you, 'Violence!' but you do not save?"'180

It is like someone standing freezing in a cold, wet alley. The ice-cold raindrops fall on him - and it is no sign of grace to him, on the contrary. His hand is on the heavy knocker and he knocks and knocks, because he knows there is someone inside. But that person does not hear, or does not want to hear, does not open, or does not want to open. 'How long, Lord? Do I have to keep knocking and knocking and knocking? How long, Lord?'

This lament does not only reverberate through the Bible or Biblical times; it expresses the experience of believers throughout the ages. It is the feeling you sometimes get when you look at the stars and they say: What do you want, little earthworm? What do you search for, little piece of dust? There is no one listening to you. It is the whispering of the wind taunting you, or the dark silhouettes of the mountains relentlessly mocking you, or the trees smiling at your despair and doubt. You stand in a bewildered, totally disabled world, you see how all your expectations disintegrate in ruins, and you look up, cry upwards, hoping that somewhere in this universe there is a God who will bend down to you, but there is no answer.

Wave after wave of injustice rolls over the world, famine drags millions from life year after year, there is oppression, anxiety, bewilderment. Fists are raised, for nights on end we pray, beg, shout, struggle. And God? Apparently, God withdraws into cruel silence. And in the morning the sky is blue - or clouded - like yesterday, and the birds sing as before. Everything remains exactly as it was. And God? It seems as if God is unaffected, utterly unaffected, by our lamentation. It is enough to drive you crazy. That, is the worst of the worst.

This is not only the experience of believers. According to some commentators a number of these psalms resonate with the so-called secularist life struggle of people, in the outspoken or unspoken belief that God no longer matters, because God no longer makes Himself matter. God has become irrelevant, uninvolved; God's face is hidden, or, if God is there at all, God is silent. This can vary from a cynical, resigned shrug about God to a bitter rejection of

179 Cf. Psalm 6:4, 35:17, 74:10, 79:5, 80:5, 89:47, 94:3, 119:84.

180 Habakkuk 1:2. 
God. For example, as expressed in the following poem from Summa 4, journal of the Theological Faculty of the University of Amsterdam, dated 12 May 1969 (translated):

"Exit fides, exit spes" (Out with the faith, out with the hope)

Humanity

for centuries applied its brain

to rhyme with God and understand him as love

But God

abandoned humanity, concealed himself in haughty silence when some people began to fathom His being.

A God

who is praised in vain in concentration camps, worshipped in vain by slaves in their songs;

a God who fought and fights side by side with all oppressors

should be denied His being.

Because God

proved again and again

in Vietnam, Biafra, the Near East

that He is but a loose thread of thought.

Humanity

hoped, expected, prayed

believed in a God of Peace.

But God

has never concerned himself with the poor

never truly saw the lowly.

Humanity

thought that someone should help the orphan

hoped that there is Someone who can stop the rivers of blood.

Humanity

will have to take God's place

so that at least a small remnant of humanity,

of plant life and animal life, can live on;

Humanity

will have to ground justice on earth

before death becomes the premature victor,

so there can be life as long as the earth

has not reached it cosmological end yet.

Is this also the case in Psalm 13 - exit fides, exit spe? God-Ichabod? 
No, there is a vast difference between this poem and the poem in Psalm 13, the latter having a totally different tone, and aimed at a completely different address. Yes, the poet struggles in Psalm 13, yes, he prays and sighs and beseeches, but at least he struggles with God for the sake of God, fights with God for God. In the process, a remarkable change takes place within him - he views the present, his struggles in the now, through a new, quite surprising lens.

This already becomes clear in the way he uses the Name of God, Yahweh, in the course of the psalm. In verse 1 this name is used in a business-like manner, almost matter of fact, followed directly by a complaint, an attack. In verse 3 it becomes an intimate: "Lord my God," and in verse 5 the accused Yahweh becomes a venerated Yahweh. The psalm begins with an accusation and ends with praise. Remarkable ...

From the beginning to the end of the psalm, there is a remarkable shift, a giant leap, a massive swing. In verse 5 , we are summarily transported into a totally different atmosphere, with completely different emotions and expressions. What happened? Did the poet's circumstances change? According to most interpreters, his circumstances remained the same. Is it due to the inherent piety of the poet, perhaps his determination to remain positive despite his circumstances? Something like the power of positive thinking? I doubt it strongly. Then why?

The secret of the psalm, one can say the secret of a faith and a hope that survives, that stays alive, lies in the first part of verse 5: 'But I trust in your unfailing love ... This faithful love is God's covenantal fidelity and covenantal love, is the relationship God forges with Israel for the sake of the salvation of the world. The poet knows: God has a goal with the world, a plan, and God will not set it aside for anyone or anything. God's plan will be fulfilled, and who can prevent this?

One is reminded of Paul's cry of jubilation in Romans 8:31-39 in which he looks back on God's faithful love as revealed in Christ. It is striking to note that he also makes use of a rhetorical question - posed four times:

If God is for us, who can be against us?

Who will bring any charge against those whom God has chosen?

Who can judge us?

Who can separate us from the love of Christ? 
And the conviction: 'For I am convinced that neither death nor life, neither angels nor demons, neither the present nor the future, nor any powers, neither height nor depth, nor anything else in all creation, will be able to separate us from the love of God that is in Christ Jesus our Lord.' Remarkable, in one breath:

How long, Lord? ... I trust in your unfailing love!

At the same time, simultaneously, the poet is so sure of this faithful love of God, even in his hour of struggle, that he uses the prophetic perfectum, a technique often found in the Bible. He is so certain that God will do as God promised, that it is as if it has already been done. He, as it were, places himself in the future he knows God will ensure. (For him this future is so unshakably sure, that he experiences it as the present ... and the present as the future.)

My children created an expression that reminded me of this: 'Today is yesterday's tomorrow.' It means, amongst other things that that to which we looked forward yesterday so eagerly, has arrived today, at last. The many nights we counted (before Christmas, in the case of my children), are over. The great moment is here. This is what the poet is saying - God's tomorrow is so certain, that it has already broken today. Today is so saturated with tomorrow, that today 'is' tomorrow, and tomorrow today. That which we anticipated, is already upon us.

That is why the poet can, in the same psalm, in the same breath so to speak, both lament and praise. That is why his rhetorical: How long? ${ }^{181}$ can transform into a: How patient is God! That is why the raw cries at the beginning become the singing and jubilation at the end, ${ }^{182}$ become a song in the night against the night; a hallelujah amidst the hesitation over the terrible things in life, and a hallelujah against this hesitation.

Yes, the poet is still in the dark, wet alley and is still knocking at the door. But he can hear the footsteps of One approaching to open the door. He knows that in a short while the door will open, he will enter and sit before the crackling fire. The cold raindrops are still falling on him, but he can already feel the glow of the fire on his skin. Tomorrow (the future) is already dawning, today, 'now' ...

Psalm 13 is the cry of someone who is still standing in the dark but has already seen the sun of God's kingdom breaking through, a sun that shines through his

181 Cf. Psalm 13:1-2.

182 Cf. Psalm 13:6. 
sombre despair and dejection. It is the confession of one who looks through the pitch-dark night and sees the invisible God. ${ }^{183}$

Is this not what another Jew, Habakkuk, also did centuries ago?

Though the fig tree does not bud

and there are no grapes on the vines,

though the olive crop fails

and the fields produce no food,

though there are no sheep in the pen

and no cattle in the stalls,

yet I will rejoice in the Lord,

I will be joyful in God my Saviour (Habakkuk 3:17-18).

If you receive the grace to confess this, is that not the best of the best that can happen to you? 


\section{Chapter 5 \\ WASTING TIME?}

Earlier, we spoke about the 'syndrome of silence' that characterised certain periods of the preaching in South Africa. ${ }^{1}$ Concerning preaching on ecological issues during 1987, the analysis was quite clear about the frequency of preaching in this regard - a resounding $0 \%{ }^{2}$

One of the almost completely neglected themes, also today, remains the issue of ecology. The mistiming of preaching in this regard is quite remarkable, more so sad, given the fact that ecology might be the most pressing issue facing not only the church, but also humanity. Personally, I think the question about the survival of our planet - God's planet - needs to be preached about far more urgently, and in a far more responsible manner. We could indeed ask, again: 'How long must systemic injustice - also against nature - still be tolerated, even actively kept intact?'

This urgent call for ecological preaching should not be labelled as an over-ethicising of life. We are again reminded of Dietrich Bonhoeffer's contention that the intention of God's law is to create structures within which we can experience and enjoy everyday life, and that we are not called to make major ethical decisions every second of every day. Therefore, we should also not overburden life in a pathological manner with the ethical. ${ }^{3}$ The whole of life is not ethics. But, says Bonhoeffer, sometimes situations and conditions arise in life in which the 'normal', everyday existence is so shattered, so ravaged, that the Church cannot avoid uttering a clear, ethical word. Then the gospel must be proclaimed as the 'concrete law for the hour.'

In this sense, the Church does not proclaim 'eternal principles' that profess 'truth that is applicable everywhere', but rather the gospel as law for the hour, being true here and now. Not all that is 'eternally' true is of necessity true 'today'. The question is: does the pollution of our planet not constitute an ethical dilemma

See the discussions in Chapter 3.

See the discussions in Chapter 3.

Bonhoeffer (1955:23ff.).

See the discussions in Chapter 3. 
of such magnitude, that the Church should urgently proclaim the gospel as truth-for-today, indeed as law for this late hour ('now', before midnight)?

Given the scarcity of sermons on ecology within the South African context, I will not be referring to examples (or lack thereof) from the pulpit in this chapter, but rather from 'preachers' and 'prophets' outside the official church and traditional theology, i.e. the cartoonists, novelists, artists, children playing, and people working on the garbage dumps, etc. In the process, I will underline some 'fundamental theological' strands of thought, which, in my opinion, could enrich our preaching on ecological issues.

According to a recent report of the WWF, we are facing the 'sixth extinction crisis', after the five known extinction waves in geological history. ${ }^{5}$ And, 'unlike the mass extinction events of geological history, the current extinction challenge is one for which a single species - ours - appears to be almost wholly responsible.6 Perhaps the next wars to be fought on this planet will not be about race or religion, etc., but rather about the quest for inhabitable land, breathable air, drinkable water, and usable energy - all the basic elements of our existence. In the meantime, we are wasting away ... and the hour is running out.

\section{What a waste ...}

The issue of waste has escalated into a planet-threatening reality. ${ }^{7}$ South Africa generates approximately 108 million tonnes of waste per annum - and it is growing. About $55 \%$ of this waste could be classified as 'general waste', $44 \%$ as 'unclassified waste', and 1\% as 'hazardous waste.' The Member States of the

World Wide Fund for Nature; formerly known as World Wildlife Fund, founded in 1961.

"The rapid loss of species we are seeing today is estimated by experts to be between 1,000 and 10,000 times higher than the 'natural extinction rate'. These experts calculate that between 0,01 and $0,1 \%$ of all species will become extinct each year. If the low estimate of the number of species out there is true - i.e. that there are around 2 million different species on our planet - then that means between 200 and 2,000 extinctions occur every year. But if the upper estimate of species numbers is true - that there are 100 million different species co-existing with us on our planet - then between 10,000 and 100,000 species are becoming extinct each year." World Wide fund (n.d.).

What follows, is a revised edition of Cilliers (2014b).

The National Environmental Management Waste Act (2008) provides the following definitions of the different types of waste: 'General Waste': "waste that does not pose an immediate hazard or threat to health or the environment, and includes domestic waste, building and demolition waste, business waste; and inert waste." 'Hazardous Waste': "Waste that contains organic or inorganic elements or compounds that may, owing to the inherent physical, chemical or toxicological characteristics of that waste, have a detrimental impact on health and the environment." 'Unclassified Waste': Refers to waste streams that are listed both under general and hazardous waste in the Waste Information Regulations. These waste streams are typically generated in high volumes but are believed to pose relatively low hazard to the environment and human health (Department of Water Affairs and Forestry, 1998). To improve the classification of waste in South Africa a more comprehensive system of classification is being developed in the form of 
European Union (EU) produce more than 2 billion tonnes of waste, including hazardous materials, every year. And this figure is rising steadily. The situation is even more alarming in the countries of Eastern Europe, Caucasus, and Central Asia. The waste generated there per annum accounts for nearly 4 billion tonnes. And so, we could go on.

Water pollution has become a threat in South Africa. South Africa is a place of many paradoxes. ${ }^{9}$ Water is no exception. In South Africa we have some of the most breath-taking waterfalls, dams, oceans, rivers - but, paradoxically, not only a scarcity of freshwater resources in comparison to our population growth, but also pollution of these scarce sources on a shocking scale. We have a water crisis. South Africa is by some standards, a 'dry' country, and the water sources that we have, are under threat.

The main factors contributing to the deterioration of water quality in South Africa are salinization, eutrophication, disease-causing micro-organisms and acidification. South Africa is facing a water supply crisis caused by a combination of low rainfall, high evaporation rates, an expanding economy and a growing population whose geographical demands for water do not conform to the distribution of exploitable water supplies.

In 2005, more than $95 \%$ of the country's freshwater resources had already been allocated for usage in different spheres of our society. The water quality of these resources has however declined due to increased pollution caused by industry, urbanisation, afforestation, mining, agriculture and power generation. Exacerbating factors are South Africa's outdated and inadequate water treatment and sewage treatment plant infrastructure, combined with the reality of unskilled operators.

the draft Waste Classification Regulations in terms of the National Environmental Waste Management Act, RSA (2012). As a result, some waste categories that were previously considered to be unclassified waste would have been monitored and classified as either general or hazardous from 2012 onwards. Since the DEA baseline report, RSA (2012), predates this development a considerable amount of waste is still noted as unclassified.

9 There exists, for instance, the paradox between poor and rich, and particularly extremely poor and extremely rich. There is the paradox between luxurious mansions and affluent estates, and struggling townships and dilapidated shacks - often situated just a few kilometres from one another. There is the paradox - in comparison to many other countries - between the highest figures of unemployment, and the lowest rates of life expectancies; the highest forms of educational inequalities, and the lowest forms of productivity rates; the most sophisticated technological advances in the world (for example the largest disk-shaped telescope, SKA, being constructed in the Karoo), and a crumbling provider of electricity (Eskom); between being able to host one of the most successful Soccer World Cups in history (2010), and experiencing some of the worst bouts of xenophobia ever (in 2008), etc. 
It is time, high time, for preaching (speak out) against waste. But what do we mean with 'against'? In what follows, I offer four brief perspectives.

\section{Anti-something?}

Firstly, 'against', in its homiletical sense at least, does not indicate a general negative attitude towards life. Unfortunately, this has often been the case. 'Protestantism' does not equate a constant protesting something or someone, but rather a way to live within the context of a new identity. (Protestant) preaching should consequently also not be usurped to become a constant campaign 'against' certain realities but should rather be an expression of our new identity in Christ. Perhaps we should critically revisit the suffix '-ism' in Protestantism. It could be misconstrued as a syndrome of we-are-against-all-and-everything.

In fact, it would be interesting to do some research on what types of closed ecclesiologies lurk behind certain negative conceptions of Protestantism - an ecclesiology that needs the 'enemy' in order to function and indeed to exist. In this sense the 'enemy' not only threatens, but also affirms; if the enemy is no longer there, such Protestants no longer have an identity and existence. ${ }^{10} \mathrm{It}$ signifies a type of Protestantism, even a God-image that exists by grace of the 'enemy'. In such -isms the gospel is often deteriorated into an 'anti-something': anti-humanist, anti-communist, anti-gamble, anti-homosexuality, anti-this, and anti-that. 'Anti' then becomes an 'essential part' of such modes of faith - which resembles Zoroastrianism, rather than Christianity. ${ }^{11}$

Secondly, (Protestant) preaching is, obviously, 'against' negative and destructive forces and realities. Silence is not always golden. ${ }^{12}$ We must protest, to oppose, to speak and act out - against. We should withstand waste. But we do this from a theological basis, not as followers of the latest (ecological) trend.

I take my cue here from the famous Roman Catholic monk, Teilhard de Chardin, who was way ahead of his times in the debate about science and faith, and about the relationship between evolution and creation. I cannot do justice to the richness of his theological and philosophical thought here. ${ }^{13}$ What I find interesting is his understanding of the Cosmic Christ - and he takes his cue in

\footnotetext{
See the discussion on 'the enemy in apartheid sermons', Chapter 3.

Cf. Cilliers (2006:30ff.).

For an exposition of the positive meaning of silence within liturgical context, cf. Cilliers (2008:19-35). See the discussion on 'silence' in Chapter 3.

13 His thoughts on the relationship between evolution, science and faith can be read in De Chardin (1977).
} 
turn from the Apostle Paul. ${ }^{14}$ For De Chardin, all of creation is underway, also through evolution, to the ultimate fulfilment under the Omega, Christ. All of reality is 'converging' towards this Pleroma, this fullness, this final unification of all things under Christ. ${ }^{15}$ This movement finds its culmination in the final triumph over all destructive powers. At present, however, there are still counter powers, resisting this movement towards the fulfilment. These counter-powers do not converge, but rather create chaos; do not fulfil, but instead fragment.

So, if we venture an interpretation of De Chardin, we could say that the pollution of creation, with the escalation of waste, may be part of this countermovement, away from the unification under Christ, back towards the chaos. Pollution stands in paradox to the Pleroma - where and when all of creation will finally come to rest. Pollution opposes the ultimate peace and fulfilment of God's creation and in doing so represents the chaos that threatens this creation.

Preaching in protest (interruptive preaching) opposes these opposing powers; represents a countermovement against the counter-powers; protest against the pollution that seeks to draw creation back to chaos. In preaching we are indeed co-workers with Christ, as Paul states, co-converging towards the Pleroma. ${ }^{16}$

Thirdly, preaching protests, but is not 'against' chaos, per se. Chaos can in fact be the first step towards order; the presupposition to new creation. Chaos can become the 'playground for new creation.' This time I take my cue from a change in aesthetical paradigm during the $19^{\text {th }}$ Century. During this era, the 'other side of beauty' was rediscovered by people like Arnold Ruge, Friedrich Vischer, and Karl Rosenkranz. ${ }^{17}$ Rosenkranz spoke about the Ästhetik des Hässlichen (aesthetics of ugliness), and called ugliness Negativschönen (negative beauty - but still beauty). ${ }^{18}$ According to this perspective, beauty should rather be understood as a space where all the disorders, the imperfections, even the evils and the one-sidedness of our experiences of reality do not necessarily estrange us from the truth, but where we rather have the possibility of stumbling upon 'truth'.

The 'ontological function' of (ugly) beauty is therefore to narrow the chasm between ideal and reality. ${ }^{19}$ In this sense, 'beauty' lies on the borders between

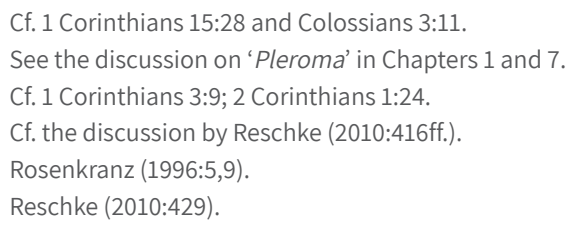


so-called order (proportion) and so-called chaos (disproportion). Beauty is simultaneously the order of change and the change of order, and as such it is fragile, fleeting, endangered, and contingent. ${ }^{20}$ According to Rainer Maria Rilke beauty is nothing more than a terrible beginning (Schrecklichen Anfang) to unthought-of possibilities. ${ }^{21}$

Within this paradigm, chaos is not viewed as the negative of order; it is not not-order. ${ }^{22}$ The Greeks already understood chaos as the possibility for order, as space and horizon filled with potential. ${ }^{23}$ Nietzsche spoke about the 'beautiful chaos of being.. ${ }^{24}$ In this sense, beauty could be interpreted as the dialectic or paradox, i.e. as the perpetual and reciprocal movement between chaos and order. ${ }^{25}$ Within this perspective, waste (or: chaos) is allocated a certain form of worth (i.e. possibility of new creation), and this brings us to our fourth perspective.

Fourthly, preaching against waste views waste as a playground for new creation, from the 'perspective of repurposing'. It brings play and purpose together. For some, it might be difficult to picture play and purpose together. So, let us view this notion of repurposing through a (playful) aesthetical lens - taking as example an artwork by the somewhat enigmatic German artist Joseph Beuys (1921-1986).

Beuys was injured during the Second World War and spent some time in the military hospital. During his recovery, he experienced first-hand the ravages of human waste and indignity, of destruction and chaos, of death and decay. He was

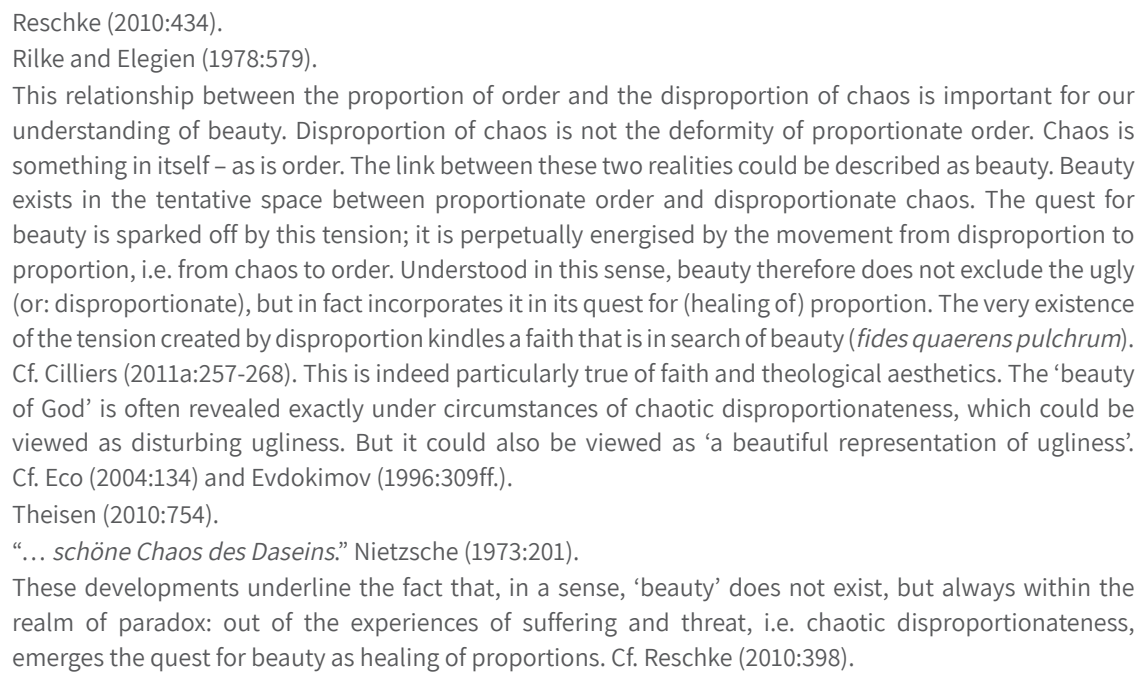
(or: disproportionate), but in fact incorporates it in its quest for (healing of) proportion. The very existence of the tension created by disproportion kindles a faith that is in search of beauty (fides quaerens pulchrum). Cf. Cilliers (2011a:257-268). This is indeed particularly true of faith and theological aesthetics. The 'beauty of God' is often revealed exactly under circumstances of chaotic disproportionateness, which could be viewed as disturbing ugliness. But it could also be viewed as 'a beautiful representation of ugliness'. Cf. Eco (2004:134) and Evdokimov (1996:309ff.).

Theisen (2010:754).

“... schöne Chaos des Daseins.” Nietzsche (1973:201).

These developments underline the fact that, in a sense, 'beauty' does not exist, but always within the realm of paradox: out of the experiences of suffering and threat, i.e. chaotic disproportionateness, emerges the quest for beauty as healing of proportions. Cf. Reschke (2010:398). 
struck particularly by the medical waste created by the hospital - used needles, blood plasma containers, and blood-soaked bandages piling up everywhere. In an artwork, entitled Crucifixion ${ }^{26}$, he makes use of items from this form of waste, and, in an aesthetical sense, repurposes it in the light of the salvific work of Christ. We could say that he gathers items from life, and 'improvises' a new form of Life, playfully repurposing it towards a new, beautiful chaos of Being. ${ }^{27}$

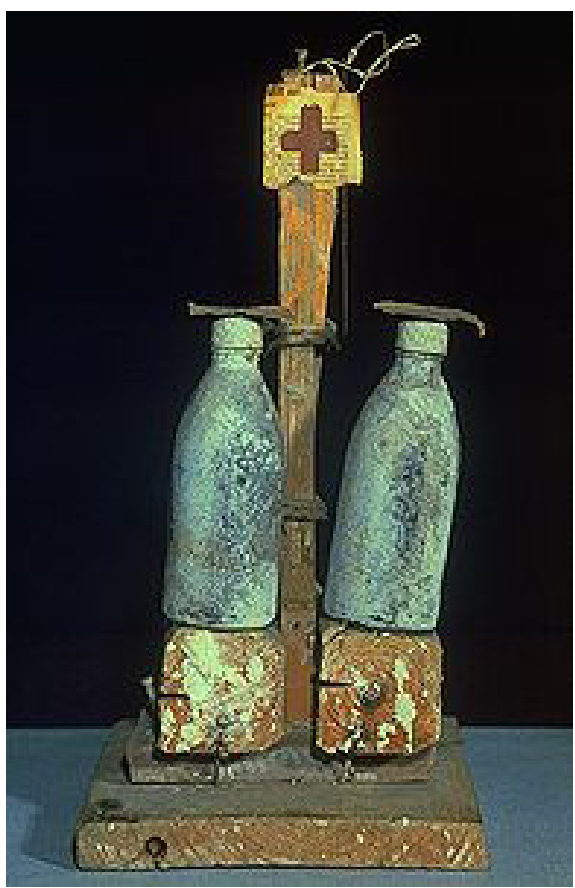

Figure 5.1 Joseph Beuys's Crucifixion (1962-1963), a sculpture made with wood, bottles, electrical cable, wire, paper, oil, plaster, nails, needles (Bild-Kunst, 2006)

This installation of Beuys went through three stages. Firstly, he felt the need to create a figurative embodiment of the entirety of Christian experience; secondly, he was overcome by a feeling of paralysing emptiness at the death of Christ; and third he felt the intense desire to embody the mystical power of Jesus' death. He described the process as follows: "For me it was a question of showing the reality of the energy. A permanently self-reinforcing existence. It

26 Bild-Kunst (2006).

27 See Chapter 2 on 'improvisation'. 
isn't a question of embodying or depicting a historical event. It's about making reality present." 28

Although the crucifix installation of Joseph Beuys depicted above retains traces of the traditional image of the crucifixion, there is also a complete renunciation of realistic, figural representation. This heightens the metaphorical significance of the objects that Beuys introduces into his artwork.

The nails and needles on the installation for instance allude to the tools used in afflicting Christ with suffering, but they also indicate physical and mental pain in general. It is quite interesting to note the role that the concept of blood plays in this installation. Three blood-red crosses (unfortunately not all seen in the depiction above) leave the viewer with no doubt as to the theme of the work, and the two old empty plastic blood plasma containers (as used in the military hospital), which symbolise blood as a life-giving fluid, cannot escape attention. It is however live giving that is inseparably linked with suffering; new creation flowing forth from chaos.

Scraps of newspaper with some words on it (unfortunately also not visible on the image) form a collage-effect and links two concepts in a contemporary manner: on the one hand, written on the bottle on the right, the term 'guilt' is quoted from the world of finance; on the other, on the left-hand bottle, one can see an engagement announcement. In this way, a sign of love is linked to the ideas of guilt and retribution. The artist calls for remembrance of the past, but in such a fashion that the timeless themes of life and guilt, blood and suffering, life and death are re-imagined.

In short: scrap becomes symbols of salvation; waste receives metaphorical significance for repurposing.

\section{From waste to worth: preaching as repurposing.}

Preaching should speak out against waste, but in such a manner that waste is viewed as a possibility for repurposing. ${ }^{29}$ In a sense, God 'specialises in the repurposing of waste.' Nobody expresses this better than Chrysostom does:

The people, once less sensitive than stones, are raised to the worthiness of angels in one deed of God's grace, simply through God's Word and their

Quoted from Guillet de Monthoux (2004:6).

It is interesting to note that someone like Moltmann regards the prefix 're-' as ironic, even negative. According to him, movements such as the renaissance and the reformation, as well as concepts like revolution, revival, renewal and restoration, all reveal a longing for a (golden) past, which implies a cyclical 
faith, without any merit on their side. 'This' is the glory and richness of the mystery of Christ. It is like when a scruffy and mange dog, ugly and deformed, which cannot even move himself anymore but lies with four legs in the air, is instantly transformed into a human being and set on a kingly throne. It is like when people who once worshipped the stars and the earth, has now gained insight that they are better than the heavens and the earth and that the whole world is there at their service. Once they decayed in the dungeons and chains of the devil, but now, of a sudden, they stand high above him, and they flagellate 'him'. First, they were the captives and slaves of the demons, but now they have become part of the body of the Lord that reigns over angels and archangels. First, they were without knowledge of God, now, in an instant, they sit on the throne 'next' to God. ${ }^{30}$

This is repurposing, par excellence.

Of course, some people might say that preaching that intends repurposing is impractical, even wishful thinking, at best merely the usage of abstract theological concepts, with no links to (real) life - especially if we argue from within a context of affluence. Indeed, we may think, this is all a royal waste of time. ${ }^{31}$ Not so for the so-called 'garbage people of Cairo'. They have, as Coptic Christians, taken waste seriously, for many decades now, and view and repurpose waste as a type of leitourgia, as liturgy-for-life; liturgy-on the-street.

The rich history and tradition of the Zabbaleen - literally, 'garbage people' - of Cairo, cannot be described adequately within the limitations of this book. ${ }^{32}$ For half a century, they have not only sustained themselves on the city's discards, but they do this from a specific Christian point of departure. On the surface, it looks as if the Zabbaleen, now numbering over 40,000, are simply running

understanding of history. It represents change while 'dreaming backwards'. He rather opts to embrace the completely new reality (novum) instead of the old (re-). Moltmann (1969:32-33). This prompts the question: Should we not rather speak of pro-volution, etc., and, in this sense, also of 'pro-purposing'?

30 Translated from Ihlenfeld (1965:35).

31 According to Dawn: "To worship the Lord is - in the world's eyes - a waste of time. It is, indeed, a royal waste of time, but a waste, nonetheless. By engaging in it, we don't accomplish anything useful in our society's terms. Worship ought not to be construed in a utilitarian way. Its purpose is not to gain numbers nor for our churches to be successful. Rather, the entire reason for our worship is that God deserves it ... Worship is a royal waste of time that spirals into passion for living as Christians and back into more passionate worship. It is totally irrelevant, not efficient, not powerful, not spectacular, not productive, sometimes not even satisfying to us. It is also the only hope for changing the world." Dawn (1999:1,17).

32 Cf. Fahmi and Sutton (2006:820); Fahmi (2005:158). A film has even been made of the Zabbaleen: Marina of the Zabbaleen (2008). 
highly successful recycling micro-enterprises that collect 4,000 tonnes of rubbish each day - about a third of Cairo's output. But on a deeper level there are theological-liturgical foundations for their activities.

Their acts of repurposing are in fact hopeful acts of dense metaphorical meaning, signifying a habitus, a stance and life-style that lives out the novum of the new life in Christ, against waste and indignity; in a sense celebrating the advent of the Pleroma, seeing the inbreaking telos of God's future with eyes of faith. They are way ahead of their times.

The ways in which they repurpose waste like plastic, cardboard, garden and household refuse are truly creative, indeed playful, continuously seeing new possibilities in objects that other people no longer have any use for. In the process, they have become a 'powerful metaphor for a life of repurposing, reminding us that we urgently need such a theology of repurposing, a liturgical-homiletical habitus that takes us to the street - and on to the dump heap.

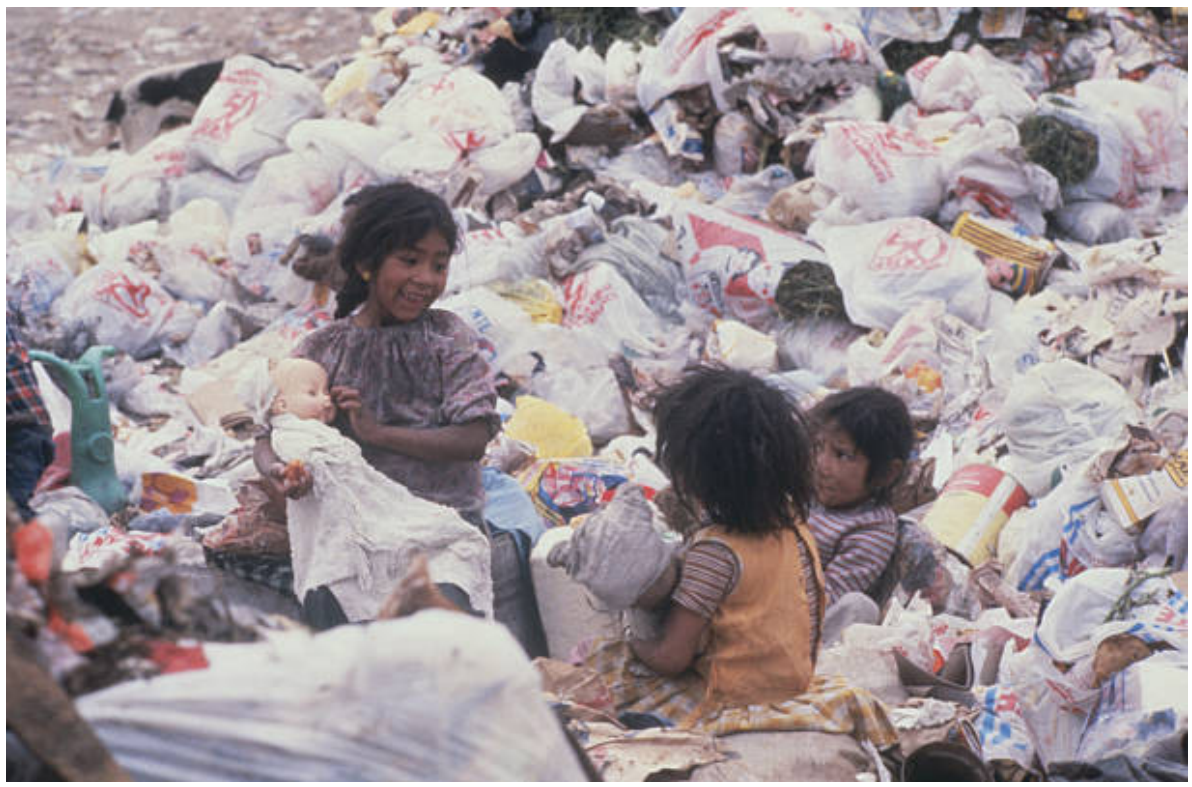

Figure 5.2 Children of members of the Sindicato de los Pepenedores, or Scavenger Union, play with dolls at the Santa Catarina Dump outside Mexico City (Bettmann, 1984)

Like the children playing with their dolls amongst the waste of humanity - seen in the depiction above. Yes, it is the children again, as in Desmond Tutu's view 
of children playing together, that brings the future into the present, that helps us to discern that today is indeed yesterday's tomorrow. ${ }^{33}$ The image of these children playing on the refuse dump symbolises the chaotic and polluted state of our planet, but perhaps it also represents - without the children knowing it - a playful, but purposeful protest against the waste on which they are sitting, and against those who allow this to be. Yes, perhaps their very childlike existence undermines the dump beneath them, giving glimpses of what could and should be - the 'grey children of God', playing in the fullness of 'Pleroma', in God's new creation.

It may seem like a royal waste of time.

In fact, it says: We are wasting time. It is time to stop the royal waste. 'Now'.

Of course, a single act of preaching cannot address, or solve, global phenomena. However, we could start where we are, with a place that is closest to us, a space that we would call 'home', in an existential manner. This is what I will be doing in the pages to come.

\section{"The most beautiful nothing in the world"}

Let me start by saying that I am biased. Completely and totally biased. I grew up in South Africa, in a place called 'The Karoo.3. I own a (little) house in the Karoo. I go there as often as possible. I call it home.

The Karoo gives new meaning to the term 'space. ${ }^{35}$ The official geographical description of this part of the world is 'arid, semi-desert'. Some would say there is nothing in the Karoo. (But it is the most beautiful nothing in the world.) Kilometres and kilometres of vast, empty planes, with a little bump here and there (small mountains, locally called 'koppies') interrupting the outstretched flat line of the horizon.

I have tried many times to capture something of this beautiful nothingness on canvass - but it is always more than I can imagine, or paint. One of my efforts looks like this:

See the discussion on 'children and play' in Chapter 4.

Many indigenous names describe the nature of the Karoo, for instance: Moordenaarskaroo (Murderer's Karoo), Hardemanskaroo (Tough man's Karoo), etc. Cf. Schoeman (2013:8-9). Cf. also my book: Cilliers (2016a). 


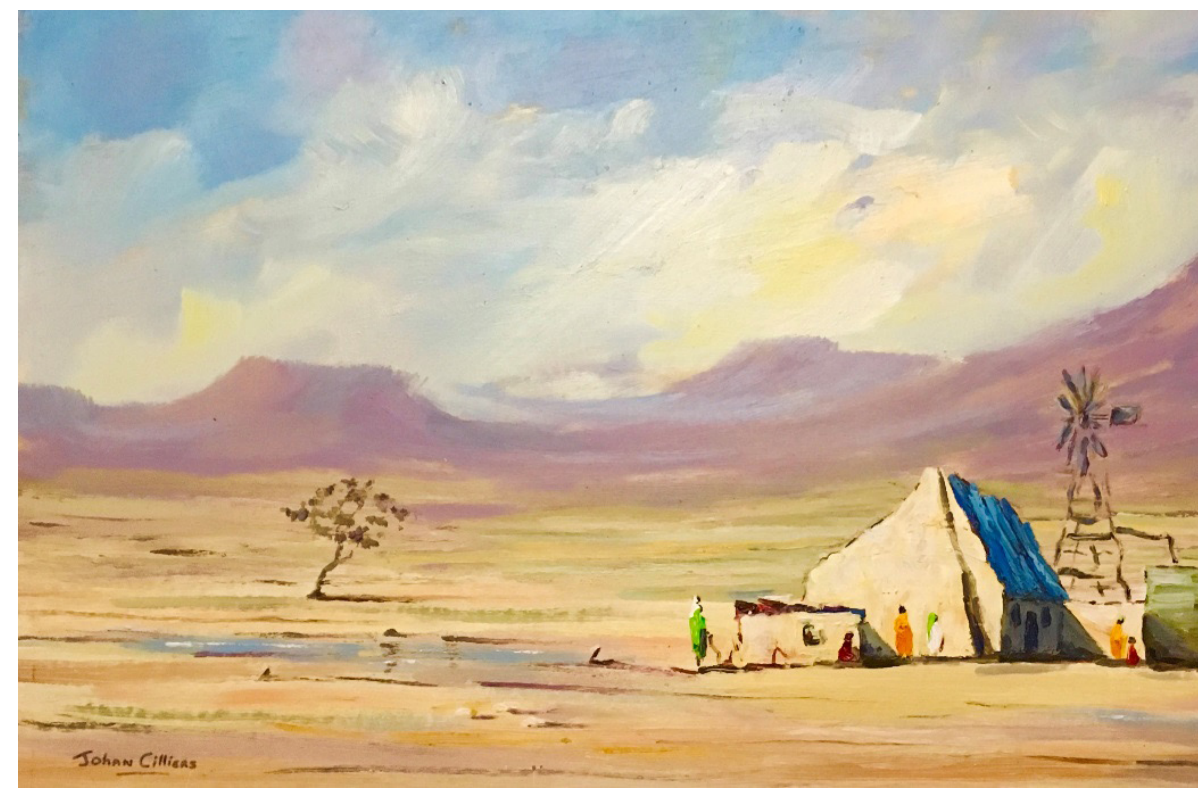

Figure 5.3 Karoo: Beautiful Nothingnes (Photo @ Johan Cilliers)

On a clear day you can see forever. Olive Schreiner, the famous South African author, once wrote: "In the still, clear air you can see the rocks on a hill ten miles off as if they were beside you; the stillness is so intense that you can hear the heaving of your own breast. This is the Karoo." ${ }^{36}$ Indeed, in the Karoo, I can breathe. I become human. I rediscover my direction.

For me, the Karoo is truly a 'landscape of the heart'; ${ }^{37}$ a holy place, a sacred, even sacramental space. 'If you take everything that does not matter away, only the Karoo remains.' It has infiltrated my being to the core and formed the first flashes of my theological thinking since I was a child. (To this day, I believe that geography plays a more important role in our religious formation than we would tend to admit.)

For those looking at the Karoo skies, like I often did as a young boy through a somewhat primitive telescope, time and space seem to converge in awe. Already at an early age, I was overcome with wonder, as I strove, in my own way, to enter into the arché of the cosmos, in a sense entering into the 'archaeology, indeed existential ontology of time and space' - imagining myself as a type of

\footnotetext{
Schreiner (2013:38-39).

Cf. Troeger (1999:85-95).
} 
astronaut at the starting point of (my) being. ${ }^{38}$ Perhaps I was already trying to formulate, for myself, a type of 'archaeology of temporality', within the framework of a (theological) understanding of the cosmos ...? ${ }^{39}$

I am still trying.

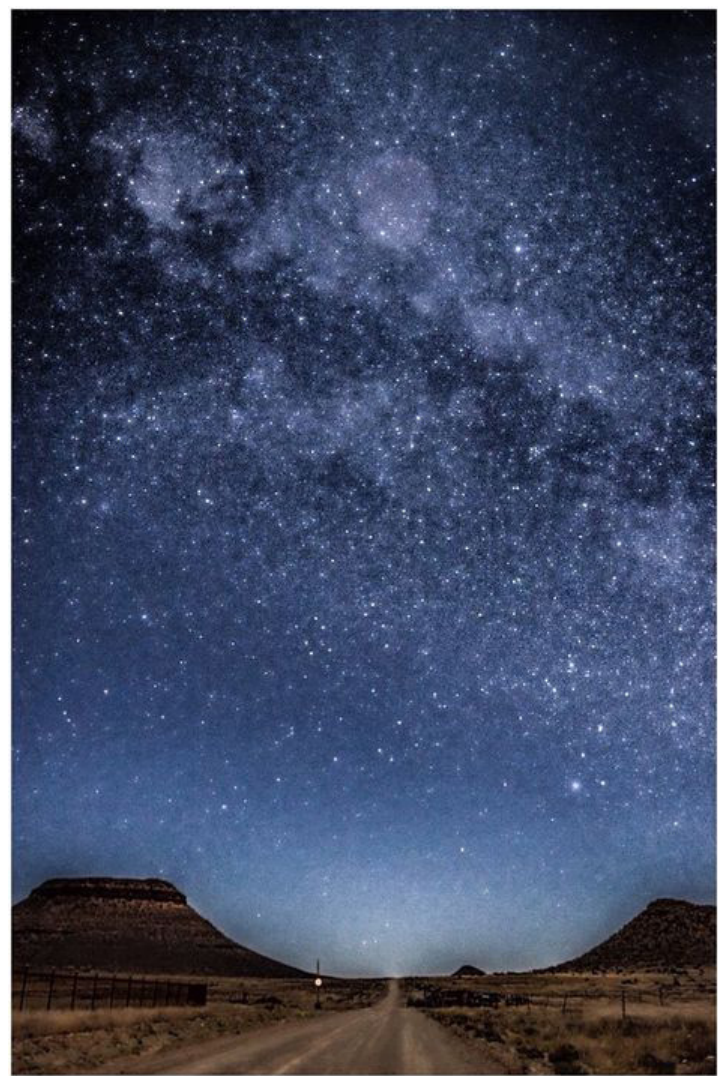

Figure 5.4 Karoo night-Colesberg - South Africa probes beyond the borders of the finite (Langerman, n.d.)

With arché and archaeology, I do not simply mean 'beginning, or even 'archetype', and not 'rigid structure'. Arché, in my mind, rather correlates with what

38 The Karoo not only reversed my perspectives on life, but in fact offered a totally new set of perspectives. It still does. I am forever in search of space - somehow still astronauting through the vast expansion of everlasting skies with the curiosity of an iconic viewer. This is a defining feature of the icon: Not only creating a reversal of standard linear perspective (as conventionally understood), but rather creating images which are not defined by perspective at all. Cf. Antonova (2010:29ff.).

39 The notions of 'archaeology' and 'temporality' represent a linking of time and space. 
Ernst Bloch would call an archaeology of movement. ${ }^{40}$ Bloch in fact links on to the Aristotelian 'arché tes kineseos' - the beginning of the movement. The principle of the beginning (arché) is therefore literally the principle of movement. Both the beginning and the principle are movement, process. In this sense, Bloch's ontology is one of being en route, of 'not yet' - beginning or breaking new ground never simply 'is', but always exists as a form of lack or need - Bloch sometimes calls it hunger - that is seeking its own meaning. ${ }^{41}$ Therefore, 'genesis' is not something completed at the beginning; it rather happens at the end. ${ }^{42}$

To this point, I would add that genesis happens when and where past or beginning (arché) and future ('not yet'), are experienced as present, as 'now'. Genesis, for me, is not so much the past of the beginning, or die future of (new) beginning, but the 'now of beginning.' Genesis is always, and continuously, now. Now always implies beginning and beginning always implies now. This is what is understood under the archaeology of temporality, or: the 'now of genesis'.

This now of genesis, seen homiletically, harbours within itself movement - the movement of the presence of God, who always starts new, always is at the beginning (or is it the end?) of time - taking us along in this movement. ${ }^{43}$ Here, neither linear, nor cyclical time can become idolised, or tormentors or escapees of history - God is present, constantly surprising us with the unexpected twists and turns of 'God's' timing, 'God's' improvisation, 'God's' synchronisation of grace, with and within the 'times like these', in which we live. These twists and turns of unexpected grace, take us to spaces and times that we could not dream of, beyond our imagination, which we could not fulfil ourselves. This now of genesis is indeed filled with vivid, warm life; it is filled with light and movement, filled with (spirals of) community; with 'Pleroma'.

40 Of course, Bloch's (Marxist, utopian) idea of hope met with different forms of critique - not to be discussed here (Bloch 1966:873). Some of the most outspoken were Jonas (2003); Schelsky (1979). See also the discussion on 'time and movement' in Chapters 1 and 3.

41 Plum (2005:206).

42 "Genesis is not at the beginning: It is at the end ... when man will have found the roots of his being, those which will allow him to transform and transcend what is given, then something will be born in the world which everyone perceives in the radiance of his youth and where no one has ever been: Heimat, a Homeland ..." Bloch (1966:1375-1376).

43 See Chapter 3 on 'movement' and 'God-images'. 
Besides trying to depict the beautiful nothingness of the Karoo, I have also tried - many times - to capture something of this 'now of the genesis' of the Karoo on canvas. It also, always, eludes me. One of my efforts looks like this:

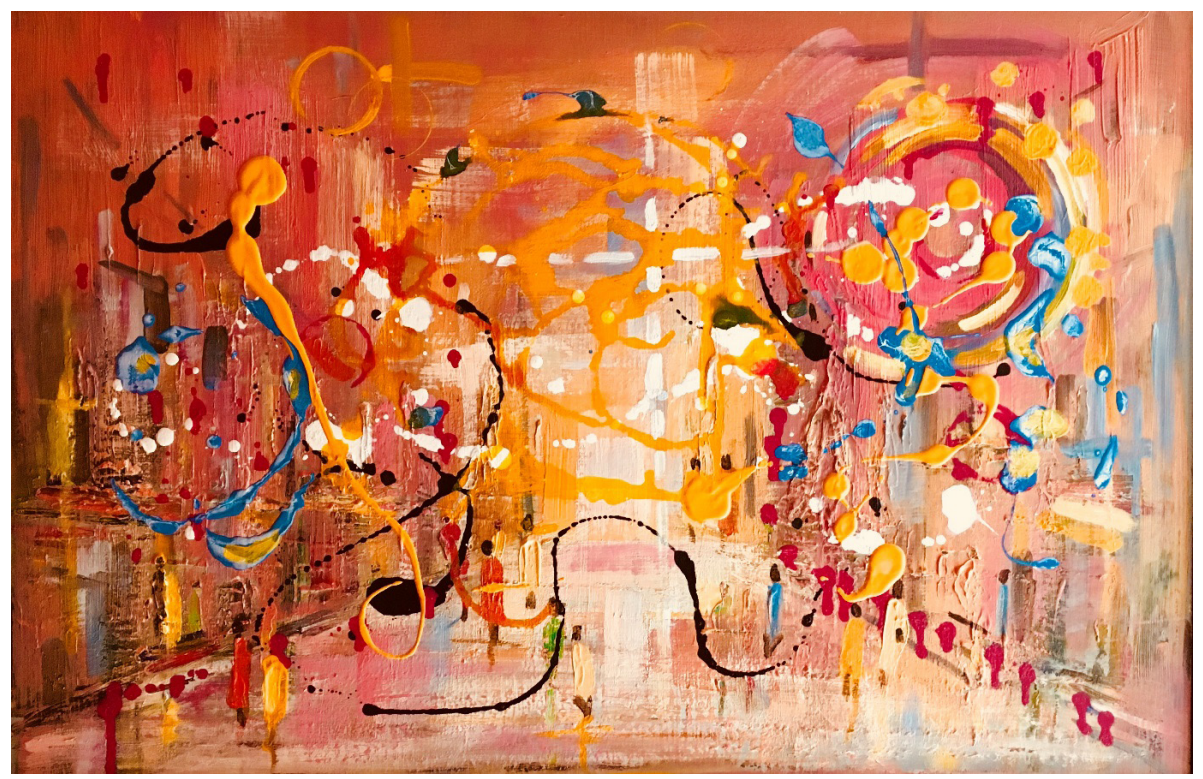

Figure 5.5 Karoo: Genesis of Now (Photo (c) Johan Cilliers)

Arché does not equate 'archaic'. On the contrary, it opens the horizon towards a future that is present, taking the dynamic movement of the cosmos, i.e. of life, seriously. An archaeology of temporality is about a body that lives and breathes; that is hungry and must eat; that could be wounded and die - now. 'Now' is not, and should not be, 'archaic' - rather filled with the Presence of a Body.

In my opinion, the ideas of Sally McFague resonate strongly with this notion. McFague has forcefully argued that the world as such could metaphorically be understood as being God's Body. For her, this implies that 'the action of God in the world is similarly interior and caring ... Furthermore, the model of the world as God's body suggests that God loves bodies: in loving the world, God loves a 'body'. Such a notion is a sharp challenge to the long antibody, anti-physical, anti-matter tradition within Christianity. ${ }^{44}$ 
As such, the Karoo is also a 'body' that God loves. This does not imply pantheism. ${ }^{45}$ The Karoo is not God, and God is not the Karoo. (But one of the ways in which I experience (the body of) God, is in and through the Karoo.) One of the ways in which I can pre-sense the Presence of God in the present, in the genesis-now of the Karoo, is through the 'body' of the Karoo.

Martin Luther often spoke of God's acts and presence in history as a disguise, or mask. ${ }^{46}$ According to Luther, every part of creation form part of God's masquerade. ${ }^{47}$ God is always present and always working. Not only did God create this world; the creation also represents God, and could be compared to a cloth, with which God is covered. There is no discrepancy here: 'God is present in every leaf on every tree and in every piece of bread that we eat, and at the same time God is beyond all that is.' The whole of history is God's great masquerade, and God's masks (larvae dei) can take on many forms: the church, preachers, but also kings and queens, ordinary working people ... and the 'body' of the creation. ${ }^{48}$

Dare I say that Luther's notion of ideo universa creatura eius est larva $d e i$ - every part of creation form part of God's masquerade - helps me towards an understanding of the archaeology of temporality, and therefore towards a better understanding of my love for a space called the Karoo? Every time I

45 It does come closer to the notion of panentheism, first propagated by Moltmann (1974), who developed a form of panentheism in his early work, where he said that the suffering and renewal of all humanity are taken into the life of the Triune God. He explicated his understanding of panentheism more fully in Moltmann (1981). Basically, panentheism seeks to avoid either isolating God from the world as traditional theism often does or identifying God with the world as pantheism does.

46 The richness of Luther's thinking in this regard is well known. What follows are merely a few strains of thought from Luther that pertain to our subject. Luther struggled intensely with experiences of a 'distant' God. To Luther, God's concealment (as deus absconditus) was a burning existential question: How can I experience (find) God in the light of my despair and uncertainty? The 'absence' of God lay on the level of his despair, but to Luther it was a 'delicious despair' at the same time. By experiencing the 'delicious despair' of existential struggles (Anfechtung), we are taught to trust in God alone. Fleeing to this (in our experience apparently absent) God, indeed in fleeing to God against God (ad deum contra Deum), we come to trust God, as known in the cross of Christ. In Luther's theology, one finds this constant tension between the act of God's revelation and the need to interpret and express this act in human terminology (for instance through preaching). In this sense, preaching as an act that unmasks concealed identities and misuse of power could be a direct consequence of God's acts of unmasking, of bringing the darkness to light. These acts of unmasking (revelation) can be seen throughout salvation history, with the apex in the Christ event that tears the curtain of the tabernacle to reveal the innermost sanctuary, and it can be seen especially in the outpouring of the Spirit on the day of Pentecost. Ultimately, it is the Spirit that opens and enlightens our eyes to discern God's presence, also in the act of preaching. Cf. McGrath (1985:171-173) and Ephesians 1:15-21.

47 Ideo universa creatura eius est larva dei; Luther (1883:40(1):174, 17(II):192).

48 Luther even said that not only positive but also destructive powers; even the devil and God's own judgement can mask the acts of God's love. The powers that destroy, however, do not understand that their actions cannot nullify God's aims and victories: they are mere puppets in God's hands. W.A. 19:207. 
see a leaf on a tree (especially after the drought), and every time I eat a piece of (especially locally baked) bread, I am looking at, and handling, a mask of God - a mask that both reveals and conceals. I touch the cloth with which God is covered.

Of course, I do realise that (our, also my notions of) space is a culturally determined phenomenon, as every culture continuously forms its own concepts of space - resulting in a variety of interpretations of the notion. ${ }^{49}$ For different cultures, powers and individuals, 'space' could mean different things. The very same space could, for instance, be interpreted differently, even radically opposing, from the viewpoint of a Karoo-child with stars in his eyes, a farmer, a land developer, an ecologist, a homeless person or displaced community.

This diversity of perspectives, often vehemently opposing, has become abundantly clear in the recent debate in South Africa about the possibility of fracking in the Karoo. Let us look at some fracking facts.

\section{Fracking Facts}

It is not necessary, indeed not possible, to go into all the technical detail concerning fracking within the limitations of a chapter like this. Basically, fracking (i.e. horizontal hydraulic fracturing) involves a vertical well that is drilled to a depth of between 2,000 meters and 6,000 meters, after which the drilling bore turns to drill horizontally for a few thousand meters. A mixture of 99-99,5\% water and sand, along with $0,5-1 \%$ chemicals are pumped under high pressure into the well. This process fractures the shale rock layer, releasing the gas trapped between rock particles. ${ }^{50}$ The process could be illustrated as follows:

49 "Physical space is continuously redefined by human presence and individual interpretation of the ideology of place." Matthews (2003:12).

50 Shale is classified as a low-permeability rock which allows substances such as water, gas or oil to move through its pores. Shale is, chemically speaking, not unlike clay, but through the effects of heat and pressure over millions of years has become flaky and hard. It is because of this high pressure that fracturing of the shale enables the gas to flow to lower pressure areas, for instance the borehole. Normal drilling techniques, for instance for oil will however not have the same effect - for this, the method of fracturing is necessary. See the descriptions by the RSA DoMR (2012:20ff.). 


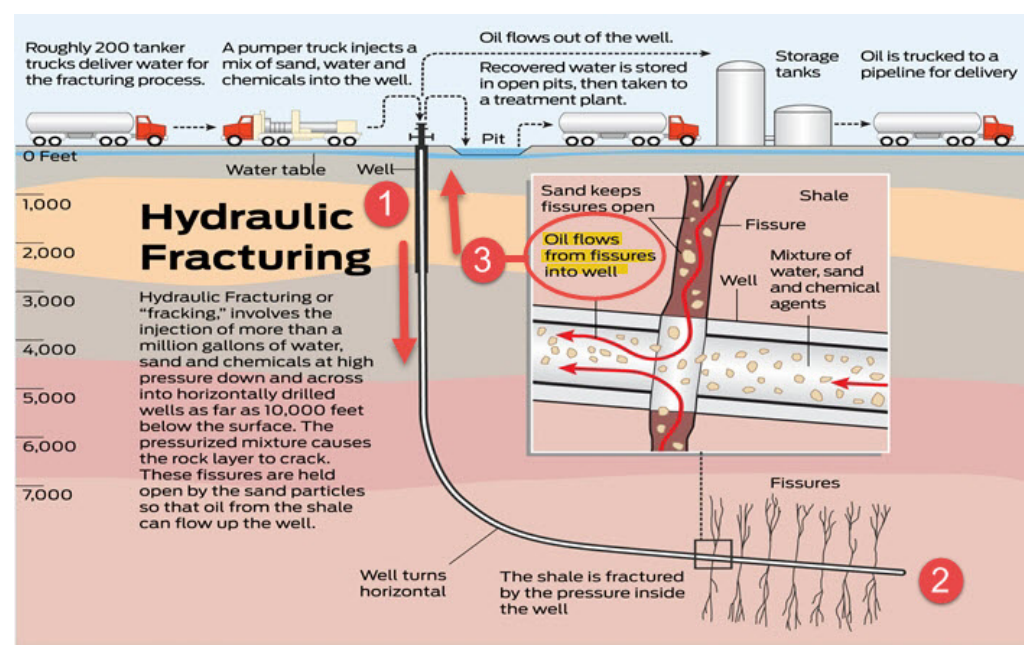

Figure 5.6 A diagram of a typical hydraulic fracturing operation (Shale Stuff, 2014)

The process of fracking in the Karoo seems to be more fraught with possible peril than in other places on the globe, given the geography and geomorphology of this region. It has been argued that the Karoo is the only place known where shale gas deposits have been intruded by dolerite, a fact that exacerbates the danger of so-called fracking fluid penetrating the many sills and dykes formed by dolerite, resulting in an upward migration of the fluid and consequent contamination of surface soil, air, plants, and agriculture. ${ }^{51}$ The problem is furthermore that these possible effects could take centuries to be reversed. ${ }^{52}$

Fracking as such is of course not a new phenomenon. It has been practised for some time in places like the United States of America, but has been banned in other countries like Germany, France, Bulgaria, Scotland, etc. The status quo in South Africa is that a moratorium was placed on fracking by the Department of Mineral Resources (in April 2012), after which the energy company Shell retracted their application for an exploration licence. This moratorium was however lifted in March 2016, when it was announced that fracking could in fact start within 12 months from then. The green light to proceed with fracking was again repeated on the $30^{\text {th }}$ of March 2017 by the then Mineral Resources Minister Mosebenzi Zwane. As far as my knowledge goes, no exploration licences

51 Dolerite is a medium-grained form of igneous rock, i.e. rock formed millions of years ago when molten lava surged towards the surface but cooled before reaching it. Sills are normally horizontally formed by this molten lava between layers of sedimentary rock; dykes are normally formed within vertical fissures between rocks. Department of Mineral Resources (2012:34).

52 It is also uncertain how much of the fracking fluid remains underground after fracking, with the possibility to pollute the earth for millennia to come. Cf. Van Tonder and Tucker (2014:1-8). 
for fracking in the Karoo have been issued in South Africa to date. 'But it seems only a matter of time ...'

According to the South African government fracking will enable many South Africans to lead a more fulfilled life, as it will provide job opportunities, counteracting the high levels of unemployment in our country. Obviously, government is also keenly interested in the resulting taxes, royalties, and revenue that would be generated through this process. ${ }^{53}$ South Africa has been struggling with an energy crisis for some time, and the exploration of shale gas, together with another highly contested initiative, namely the introduction of several nuclear plants in South Africa, was seen, until recently, as a 'sustainable solution' to this problem. The notion of sustainability is furthermore fuelled by the sheer enormity of possible reserves in the Karoo Basin - estimated at 485 trillion cubic feet of shale gas. ${ }^{54}$

The economic benefits of fracking are claimed to be potentially immense. In a controversial study commissioned and paid for by Shell, one of the original applicants to explore for shale gas in South Africa, developing one tenth of the estimated Karoo for fracking could generate 200 billion rand per year and create 700,000 jobs. An estimated 200,000 holes will be drilled during gas exploration in the larger Karoo basin, so as to provide enough gas for 200 years of energy use in South Africa. ${ }^{55}$ These and other data are used to propagate the idea that fracking could be 'a flagship for so-called 'sustainable development' in South Africa'.

But at what (real) cost?

\section{Frack off!}

As stated above, and understandably so, the debate about fracking in the Karoo has been highly charged, given what is at stake here. Not all share in the euphoria

53 Department of Mineral Sources (2012:54).

54 This claim has recently been contested in a scientific study, Wit (2010). This study indicates that the Karoo shale deposits are 'over-mature' (cooked to the point where most gas has disappeared). New evidence that the shale gas potential of the Karoo is grossly inflated is part of an emerging worldwide pattern - where 'game-changing' economic opportunities from the gas fracking industry are deliberately manipulated or overstated. Prof Michiel de Kock, the study's lead author and head of geology at the University of Johannesburg, said the United States Department of Energy published a report in 2011, estimating the Karoo basin's recoverable reserves to be 485 Tcf (trillion cubic feet), suggesting South Africa had the fourth largest shale gas reserves in the world. This estimate was later revised down to around $390 \mathrm{Tcf}-$ but a new study by de Kock and a team of researchers from several other universities suggests both these estimates are 'grossly inflated' and that the actual reserves are more likely to be around 13 Tcf.

55 Shell South Africa (n.d.). 
about shale gas. On the contrary, several civil organisations have taken up arms against government concerning this matter. ${ }^{56}$ Countless blogs speak out against fracking. ${ }^{57}$ The mood on street-level is particularly clear - perhaps illustrated best by a caption on a T-Shirt that reads: 'The F-racking word is a dirty word.'

Countless artists have joined in the fray - the cartoonists not in the least. The example by Zapiro says it all:

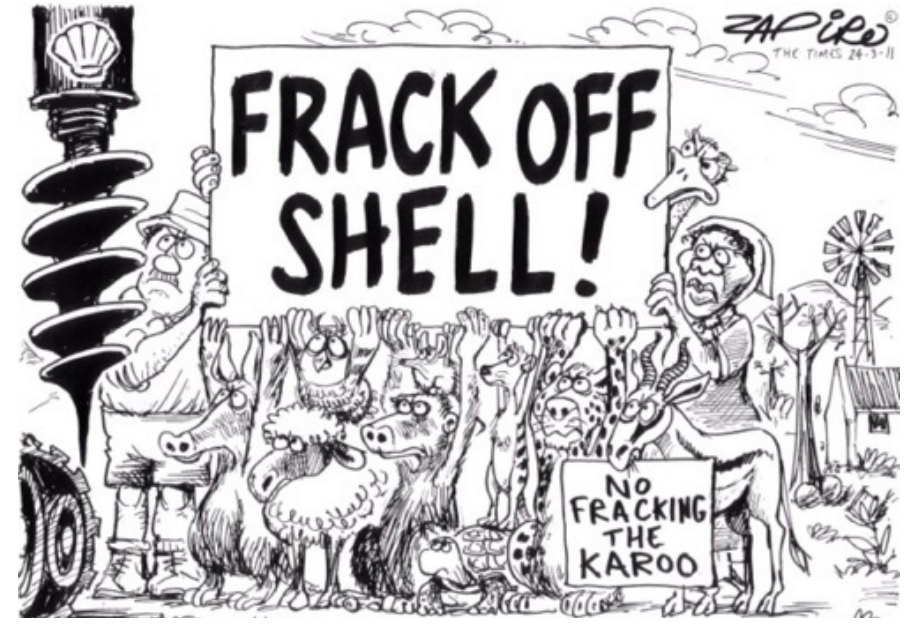

Figure 5.7 Zapiro's Royal Dutch Shell fracking in the Karoo was published in The Times (Zapiro, 2011)

Some South African churches have also joined in the protest. Archbishop Thabo Makgoba, for instance, wrote a moving letter on 14 November 2013 on behalf of the Anglican Church, addressed to the South African authorities,

56 For example, Earthlife Africa, Treasure Karoo Action Group, Saving Water SA, etc.

57 "So, our government has given the go ahead for drafting fracking rules in South Africa. The Business Day article calls it the 'green light' but there is nothing green about it. Of course, this is simply another step into the inevitable downward spiral chasing after easy billions no matter what the cost to our fragile environment ... For residents in the region the idea of fracking is disturbing. Would we not all feel this way when we realise how brutal the process is. No, it is not about jobs for the unemployed. Fracking is not sustainable. Once the deed is done the foreign companies will move on leaving all sorts of social and environmental scars ... Fracking is safe they say? Look at the recent spill in North Dakota and tell me that anyone wants to see that in the Karoo. We need to remember that the Karoo's water comes from ancient springs underground. It is not being replaced. Once contaminated that is it! Gone." Dewey (2013). One of my favourite commentaries on fracking can be seen in a satirical episode of The Simpsons, the iconic American television series that more than often speaks truth in jest. See Abdalla (2014). 
criticising the short-sighted process behind the seemingly rushed drive to get fracking in the Karoo Basin going. Concerning the risk to water, Makgoba states:

South Africa is a water scarce country. The Karoo has a particularly fragile water table. Fracking uses chemicals which are toxic and there is the possibility of chemicals entering the aquifers if pipelines or cement casing is damaged. Furthermore, the process involves the disposal of large amounts of toxic water which could impact negatively on humans, animals and plants.

In a rare show of unity, the Dutch Reformed Church (DRC), the Uniting Reformed Church in Southern Africa (URCSA), and the Reformed Church in Africa (RCA) speaking 'on behalf of approximately 2,4 million Christians in the reformed tradition, with congregations throughout South Africa, of which many are in rural areas', drafted a combined letter, dated November $7^{\text {th }}, 2013$, addressed to The Director General: Mineral Resources. The letter states, inter alia, the following:

There is always a danger that short- and medium-term interests will outweigh long term well-being. A century or more of mining in South Africa has polluted its water sources in a way that will have an impact for many centuries to come. If there is any possibility that hydraulic fracturing would have a similar impact, short term economic gains, also for impoverished rural people will simply be short-sighted. Here a precautionary principle must apply. There are times when prohibition instead of regulation is appropriate ... It is widely acknowledged by experts and feared by people in civil society that hydraulic fracturing may have side-effects, most notably on the pollution of water sources. The extent of such side-effects will only be known in hindsight. Such fears therefore cannot be dispelled by more reports or government assurances and will not go away.

The notion of 'a precautionary principle' as advocated by the churches in the letter above, has in fact been debated by various ethicists. Wolfgang Huber, for instance, following the cue of Hans Jonas' classic book The Imperative of Responsibility, ${ }^{58}$ describes the advantages and disadvantages of this principle at length, and concludes:

Under the conditions of uncertainty, a special kind of caution is needed with regard to actions with irreversible consequences. We have to add: This irreversibility has to do not only with the life conditions of present 
but also of future generations. Actions with irreversible consequences require a high degree of precaution, even if a high degree of uncertainty is involved..$^{59}$

Not surprisingly, some of the most vocal opponents to fracking come from inhabitants of the Karoo itself. For instance, the well-known author, Etienne van Heerden, has written volumes about the Karoo. ${ }^{60}$ One of his works is entitled Poison Karoo, not without reason. ${ }^{61}$ Poison Karoo was written out of concern and dismay at the proposals for fracking, and is a work of fiction, written as if commercial hydraulic fracking has already begun in the Karoo. It depicts an inhabitant of the Karoo returning after many years to his childhood space and being shocked by the apocalyptical aftermaths of fracking. The following haunting quotes from the book speak for themselves:

He knows how things can drill deep down, how they can branch and crack and spread and fill with poison, the pressure building up so that small tremors deep in one's spirit can destroy you without your even knowing, on the surface.

You only realise later - too late - when what issues from you begins to taste bitter to you and others around you, and you know there is nothing left inside you that is pure and clear.

You can't grow up in the Karoo without a feel for groundwater, the deep water. He knew how clear it ran down there: how ancient it was. As old as the centuries, untouched by the hand of man - that was how the water tables and the narrow lakes and fine veins of deep water lay, so deep under the ground that sometimes a dowser walking over it with his forked stick felt no life there, so deep and secretly it lay.

It was the unconscious of the Karoo, the place from which the fountains drew their water. It was a quiet, private place, that place of water.

(Meddle with water and you're meddling, deeply and dangerously, with the very soul of the Karoo.)

59 Huber (2012).

60 Books by Etienne van Heerden which feature the Karoo landscapes are, among others: Haai Karoo (2012), 30 Nagte in Amsterdam (2008), Asbesmiddag (2007), In Stede van die Liefde (2005), Die Stilte na die Boek (2004), Die Swye van Mario Salviati (2000), Kikoejoe (1996), Die Gas in Rondawel Wilhelmina (1995), Die Stoetmeester (1993), Casspirs en Campari's (1991), Liegfabriek (1988), Toorberg (1986), My Kubaan (1983) and Matoli (1979). Van Heerden grew up in the Cradock and Graaff-Reinet districts. 
Now the petrol giant had come, boring holes through the strata, sending jets of poison water filled with chemicals down to explode and fracture, so that the poison sprayed and seeped through the deep veins and aquifers, and he who knew about water, who'd grown up in a house where 'water' was the one word that was even more beautiful than the words 'faith', 'hope' and 'love', he who came from that home, the son of a water bailiff, he knew it was a poison that would dam up in the unconscious of the heartland for ever. ${ }^{62}$

\section{Fear and Loss}

Let me return for a moment to the notion of an 'archaeology of temporality', mentioned above. In my understanding of this, any destruction, even any 'credible doubt' ${ }^{63}$ whether destruction will take place, or not, constitutes a destruction, or possible destruction of the body of God. If the Karoo is wounded, the body of God is wounded. If the 'genesis of now' is terminated, the possibility of beginnings - or endings - is terminated. If the arché is annihilated, genocide is perpetrated - on God's body, and our bodies.

The Karoo is vulnerable. God is vulnerable. The drive for commercial gain, often fuelled by political power and opportunism has no room for vulnerability - on the contrary. Neither does it show signs of a spiritual and qualitative-aesthetical approach to the problematic issue of, and possible outcomes of fracking. So-called 'sustainability' might in fact be nothing else but an expression of gain and greed. And, gain and greed show little patience for any form of 'precautionary principle'.

Gain and greed chokes to death, making use of 'slow violence.' The environmentalist Rob Nixon wrestles with this phenomenon of 'slow violence', and the challenge to tell stories that do not fall prey to the journalistic tendency towards immediate and spectacular narratives:

How can environmental writers craft emotionally involving stories from disasters that are slow-moving and attritional, rather than explosive and spectacular? This is a particularly pressing question for our age, as the news cycle spins ever faster, as the media venerates spectacle, and as public policy is increasingly shaped around what are perceived as immediate needs ... Think of the narrative challenges posed by these 
examples of what I call 'slow violence': climate change; the thawing polar ice-caps; the slow toxic drift of agricultural nitrates from the heartland down the Mississippi to the Gulf's deep delta, creating a vast dead zone larger than New Jersey. Think of oil spills, deforestation, and a host of other slow-moving environmental disasters, like the ongoing chemical and radiological legacies of wars that officially have been concluded. Under such circumstances, slow violence often fuels social conflicts that arise from desperation as life-sustaining conditions incrementally - rather than suddenly - erode. But the long-term emergencies that result are readily marginalised or ignored by hard-charging news organizations in pursuit of quick, eye-catching stories. ${ }^{64}$

It is my contention that sentiments such as vulnerability and wounding through 'slow violence', in distinction with power and political greed are, more often than not, best understood and illustrated in an aesthetical manner, by artists. ${ }^{65}$ Artists do seem consistent in their critique of social events - speaking out against 'slow violence', i.e. events taking place in society, often under the banner of 'sustainability' that in fact are sabotaging sustainability - a slow form of violence, that ultimately destroys and kills.

I believe that fracking in fact represents a form of slow violence, of strangling the life (i.e. water) out of the Karoo. Artists sense these seismographic events, often long before theologians, and ahead of politicians. Their aesthetical expressions often carry deep religious tones. ${ }^{66}$

64 Nixon (2011).

65 The notion of aesthetics should not be misunderstood as only pertaining to the superficiality of prettiness and inoffensiveness. There is something like 'a beautiful representation of ugliness'. Cf. the discussions by Reschke (2010:416ff.); Cilliers (2011a:309ff.).

66 On a 'theological' level, and to my knowledge, not too much has been written about fracking in South Africa. Writing from an evangelical perspective, Van Tonder and Tucker has tried to formulate what they call 'earth-care metaphors' to foster a debate by the Christian faith community in South Africa, namely Fruitfulness, Earth-keeping, and Sabbath renewal. They position themselves explicitly as follows: "Postmodern deconstructionist 'theologies' relating to mankind's stewardship of creation, such as Clayton et al. (2004)'s panentheistic approach and Wallace (2001)'s pneumatological enfleshment of God in everything, are not appropriate for our target audience. To be convincing to such an audience, the hermeneutic needs to be easily understandable, systematic and clearly based upon Christian scripture, which many accept as their final authority concerning belief and conduct. Therefore, we have opted for a more conservative, evangelical reformed theology that can be perceived as coming directly from a biblical hermeneutic." Van Tonder and Tucker. Obviously, the notion of 'responsible stewardship', as represented in the approach of Van Tonder and Tucker could be a viable route to follow. It may still fall prey (often unknowingly) to the idea of domination - a tendency that has been part and parcel of evangelical Christianity for a long time, and indeed does not fit into African beliefs of the intrinsic value of all forms of life. Van Tonder and Tucker (2014:3). Cf. Conradie and Ayre (2016:41). 
One example is an artwork that formed part of the exhibition, Industrial Karoo - Fear $\mathcal{E}$ Loss, with over 80 artists and curated by South African artist Katie Barnard du Toit. ${ }^{67}$

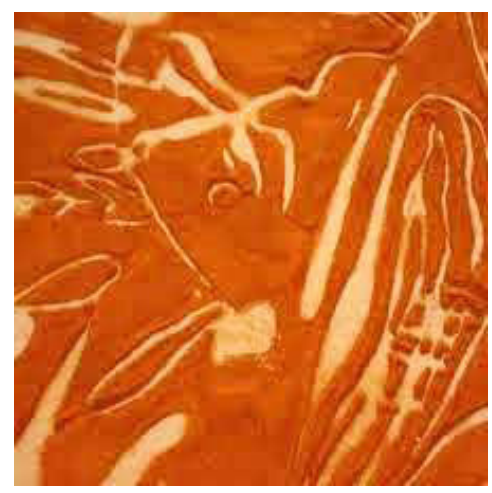

Figure 5.8 An artwork from the Industrial Karoo - Fear \& Loss exhibition, curated by South African artist Katie Barnard du Toit (De Kock, 2014)

This artwork has many dimensions, many layers of meaning: the lighter areas and line-forming represent the underground sills and dykes formed by dolerite, which also forms the life-giving 'veins' along which the water flows - the very lifeblood of the Karoo. These are the veins of the body of the Karoo. ${ }^{68}$

But at closer look they also resemble the richness of fossils, for which the Karoo is famous. Can we discern a flying reptile in the centre, top? A Dinosaur skeleton bottom, right? Perhaps a fossilised octopus in the centre - keeping in mind that the Karoo was once a huge swamp, millions of years ago?

But more: the lines also suggest ancient rock-art drawings, created by the indigenous Khoi and San people, centuries ago. Could we imagine them dancing around their fireplaces, celebrating rituals? ${ }^{69}$ Perhaps the brown colour with its markings depicting an animal skin, like that of a Nguni ox, symbol of sustainable wealth? A skin, that represents God, to be compared to a cloth, with which God is covered?

\footnotetext{
67 Originally displayed at Oliewenhuis, Bloemfontein, South Africa.

68 The word Koup (one of the regions of the Karoo) means caul fat and was so named because the patches of golden veld grasses interspersed by the dark grey-brown ground resembles the lacy fat and blood vessels surrounding a sheep's liver. The contrast between the grassy patches and the ground is best observed at the beginning of winter when the gold and brown patches are most evident.

69 See the discussion in Chapter 7.
} 
In short, I would venture to say, these lines and figurines suggest the 'sustainability of an iconic landscape', existing long before humans came on the scene, but also inhabited by humans, ancient and recent. Truly, the Karoo has something 'eternal' about it. It is a landscape that sustained and sustains life - even through periods of past and present seemingly catastrophic drought.

But there are even deeper meanings: this profound work of art excels in its depictions of vulnerability, indeed of fear and loss. Beneath the mask of life lurks the vulnerability of life - the vulnerability of the Karoo people, who knows on an existential level how dependant they are on the body of the Karoo.

Do the lines for instance indicate the fractures of fracking, instead of sills and dykes? Is this space about to be cracked open, fragmented, exploded? The choice of colour is also not by chance. The brown colour could represent the skin of an animal or the richness of the soil, if they are being fed by the arteries and aquifers of life-giving water. But this colour could also be an indication of the sludge of the fracking-fluid, bubbling up, threatening to cover the vulnerable lines and figures of Karoo-life. Are these life-giving lines on the verge of being submerged? Forever vanishing beneath the choking of rising, poisonous waste? Does the colour point towards 'Karoo Poison'?

If these vulnerable signs of life vanish, it might never re-appear. Sustainability will be a haunting memory. The Icon called Karoo will be Ichabod.

Nothing will remain.

It will 'not' be the most beautiful nothing in the world.

But as I said: I am biased. Completely and totally biased. 


\title{
SERMON: WHO EXALTS, EXISTS
}

\author{
Let everything that has breath praise the Lord. \\ PSALM 150:6
}

Why am I here? Why am I? Now?

This may sound strange, but it is true. There is not a single person on earth who has not, at some stage, wondered about the meaning of all this, of life. There is no-one who does not sometimes wonder: 'What is really my purpose, the meaning of my existence on earth? If I consider it, if I reflect on my little bit of history until now, what is the point of it all?'

Perhaps we only ask this in times of crisis in our lives. Or perhaps in the most amazing moments in our lives, like the birth of a child, when we pause, awed by the wonder of life. Perhaps at the sound of wedding bells, or, alas, the sound of clods of earth on a coffin. We wonder: 'What is the significance of my joys and grief? What is the meaning of all my achievements and frustrations? What is the point of all the times my heart has beat, the number of steps I have taken, the footprints I leave behind in the course of my life? What, ultimately, does it mean? In the light of eternity, of the centuries that roll over us, am I but a small bit of plasma in the universe? Am I but a fleeting second? Am I but a breath of air that comes and goes, and then my time is up, my story is done?'

This is a serious issue, and yet we should retain our humour. We should not take ourselves too seriously anyway, because we do not have the answer to this important life question. This reminds me of the Afrikaans-speaking young man who really wanted to work the streets for the Lord, but his English was not very good. One evening he met an old English woman, and decided to persevere and ask her the question he wanted to ask, so he asked her: "Lady, what is the big sin of your life?" [Sin is the Afrikaans word for 'meaning'.] She threw him an angry stare, and he realised that he had confused the word 'sin' in the two languages. So, he tried to correct it by asking: "Excuse me, lady, tell me, what makes your life really sinful [meaningful]?" And that was the end of the conversation. He did not manage to save her soul that night ... 
But whether you ask this question in broken English, or Afrikaans, in Spanish or Italian, in German, Dutch, or isiXhosa - we all ask this ultimate question.

The poet of Psalm 150 answers this question by saying, 'celebrating the diversity of God's creation'. We, and all that is, exists for God. In fact, if we learn to praise, we have learned to live; whoever taught us to praise, taught us to live. Everything that was - the past; everything that is - the present; everything that is yet to come - the future, is there for one reason only, one final purpose - to praise God, to worship the Lord, simply because God is God. Who exalts, exists.

Psalm 150:6 says: "Let everything that has breath, praise the Lord." You could rephrase this: Let all that breathes, proclaim the Name of God. Let all that breathes, worship the Lord. Let all that breathes, admire God. Let all that breathes, enjoy God. One of the best-known catechisms of the church, the Westminster Catechism, asks: 'What is the chief end of human beings?' What is the highest purpose and meaning of human existence? The answer is: 'Human beings' chief end is to glorify God, and to enjoy God forever.' The highest calling and the highest meaning of human existence is to enjoy God perfectly unto all eternity. The highest vocation in our lives, is to laugh - about God. Well, do we laugh about God? Do we enjoy God? Is our religion a pleasure, or a joyless toiling, a boring endeavour, a soulless affair?

'Let all that has breath, praise the Lord.' This invitation is enough to make you lyrical. Let all that crawls, moves, or glides, all that lives and breathes, praise the Lord! Verse 1 refers to all under God's mighty heavens; so even that which does not breathe, can and should praise God. Masses of matter in the darkest corners of this universe, suns, galaxies, planets, comets, power, space, time and energy, everything we can name in the great universe; everything on earth, the smallest worm in the sandy desert plains, the tiniest ant in the deepest forests of our continents, the autumn leaves that fall, the blue peaks that reach for the sky, the glory of sunsets, the twittering of birds, the thunder of waves breaking - let all that is, all that has breath, praise the Lord.

Truly, creation is there for God - and us - to enjoy. If we smother this creation with our plastic and our pollution, we are simply killjoys. And that's a fracking fact.

A well-known German author, Wilhelm Fischer, compares creation with a mighty pipe organ. Each one of the pipes makes a unique sound. The big pipe, the bass pipe, makes its unique rumble. The small pipes, some of them as small as a darning needle, make their delicate sounds. If any pipe is played alone, 
it is monotone, boring. But when they all come together in play, it becomes meaningful. Together, they are majestic; together, they are a symphony; together, they are a mighty, glorious, holy organ concert. This, Fischer says, is creation. And it is almost as if God, as the great Maestro, conducts this mighty organ to bring forth the most beauteous sounds from this creation, God's creation.

'Let everything that has breath, praise the Lord.' Do we understand at all what it means to praise the Lord? Not just occasionally, in a passing moment, thinking a few loose thoughts of praise, but a life characterised by expressing the praise of God, in every heartbeat, in every moment of your existence. Do we understand, and embody this?

This question is particularly pertinent to God's people. In fact, Psalm 150 starts with God's people when the poet says: Praise God in God's sanctuary, verse 1 . The sanctuary was the ancient temple, the holy place where God's people should praise God in particular. Verse 2: Praise God for God's acts of power; praise God for God's surpassing greatness. Especially someone who has experienced the mercy, the grace, and the love of God, is called to praise God. Someone who has experienced that God is not only great and mighty, but also merciful and loving ... giving us breath to exist, to exalt.

'What a thought': we, the church of the Lord Jesus Christ, can praise the Lord even more eloquently, with even greater understanding, than the poet of Psalm 150. Because, for us verse 2 is a prophetic verse: We praise God for God's powerful deed in Jesus Christ, for the gift of the Son. God wanted us to exalt and to exist, so much so, that the Son was resurrected from death and the grave, to animate our exaltation, and grant us existence. Psalm 150 indeed is also an Easter celebration. Psalm 150 is full of life and meaning. It could read: 'Praise the Lord, for He has risen, and lives. Hallelujah!'

'What a thought': the psalmist is saying - come, world; come, creation; come and look at God's people. Come and listen to the small temple orchestra of Israel. He names the instruments of this temple ensemble, one after the other - the trumpet, the harp, the lyre, the tambourine and dancing, the string instruments, the flutes, the cymbals, the resounding cymbals. And in the same breath he says: Come, all who breathe; come, whole of creation; come and listen to God's people, for this is how we should sing, this is how we should praise. This is how we should exalt and exist.

'What a thought': we can sing better and more beautifully than the world and creation could. Do we? We have experienced the love and grace of God. We 
have the sheet music - the Word of God - from which we can read how to sing and play, with meaning. We have received the Spirit of God as conductor, who keeps us in tune. We, the church of Christ, can go into the world and praise God in every relationship in life, every context. We can praise God in such a way that the world finds us attractive; play and sing in such a manner that the world is drawn to us like metal to a magnet, so that the world can play with us, sing with us. Would they?

Whether you are a shopkeeper or banker, a scholar, lecturer or student, employer or employee - you can play and sing and rejoice in such a way that it attracts others, make other people also desire to play and sing with you. And if we no longer know how to do this, we can come to the sanctuary of God, to study the sheet music, to re-find the notes, to be tuned-in by the Spirit-Conductor ... so that we can go out and sing and play and rejoice, as if for the first time.

What is the church? How could we define ourselves? These days much is said and written about the church. Indeed, there is much to be said about the church. Books on dogma, decrees from Synods, and ecclesiological strategies are all in order. How neatly we formulate our sacramental formulas, or how innovative we construct our theological theories, or how seemingly relevant we are in step with the 'times', are commendable. But, let us be reminded, now, of 'this one, fundamental dimension. Let us re-enter, now, this 'moment of profound meaning. This moment of praise, which defines the church as people of God. This moment of worship. This moment of wonder. This moment of jubilation, celebration, and joy. This is who we are - exalting and existing; existing and exalting.

Perhaps you are waiting for better circumstances. Perhaps you think right now, I suffer too much, and suffering and praise do not go together. Suffering and praise cannot live under one roof. The poet of Psalm 150 invites us to rethink our position. In the process, he points us in the direction of the 149 psalms preceding this psalm. The poet of Psalm 150 sings his psalm after having experienced all that the first 149 psalms describe. He has lived through the highs and lows of human suffering. He sings Psalm 150 after experiencing the godforsakenness of Psalm 22, after traversing the dark depths of Psalm 23, after he cried to God like a deer, panting and thirsting for a drop in Psalm 42, to name but a few. He sings despite his suffering. His 'Hallelujah' is far removed from superficial optimism or shallow happiness. 
'What a thought': perhaps he is singing Psalm 150 alongside Job on the ash heaps of life, with sores on his body, and suffering in his soul. Perhaps his 'Hallelujah' comes from his lips amidst trauma and tears ...

Many interpreters of Psalm 150 have compared this psalm to Beethoven's Ninth Symphony, although the two, musically speaking, are poles apart. Yet in his symphony Beethoven did exactly what this poet did - he sings praise from the very depths of his life, even from his suffering and grief. In the first movements of his symphony, you hear his sorrow for his deafness, the loss of the most beauteous of all he knows - sound. He is saddened, yet his symphony bursts into praise to God, joy in God, for whom all has, and is being created.

We are not the poet of Psalm 150, nor are we Beethoven. But, each one of us has been created to exist; we have been given breath to exalt. And, if we lose our tune, we may, God-willing, catch our breath and exalt ourselves back into existence. Or, have we become so programmed, so structured and busy, busy, busy - so dictated by our diaries and calendars and watches that rule our lives - that we no longer have time for existing and exalting, 'right now'?

I sometimes think we tend to be like moles. I do not know if moles are a problem in your garden, but sometimes it feels like they have entire, well-organised rallies in mine, in a secret conspiracy, or rather open rebellion against all aboveground events. As if they have dug a bunker underneath my lawn - the headquarters of the Mafia of Moles. It infuriates me, but I also sympathise with them, for they reflect us people. Because we are sinful, we do everything except praise the Lord - that is indeed the big 'sin' of our lives.

We seem to be born that way. We are of this earth, and like moles, we dig around in the ground. We keep ourselves busy with underground activities. We are underground agents. We plod through the mud. We frack everything up. Our eyes have become blind to the world of light and praise.

Of course, moles are also part of God's creation - begrudgingly admitted. However, if I could choose, I would rather be a bird that can fly into the blue skies, towards the sun, that can twitter and chirp. If I could choose, I would not be grinding away in the ground like a mole, but rather be free as a bird, free to sing, free to exist, free to exalt God.

'Let all that has breath, praise the Lord!'

'That' is why I am here. Why I am. 'Now'. 


\section{Chapter 6 \\ TIMING THE TEXT}

All the sermons that we have quoted in this book, in some way or another, make use of Scripture. The question now is whether it is possible to talk about a connection between timing and mistiming (of grace), and the biblical text? Could we talk about a homiletical act of 'timing the text'? What would the characteristics of such an understanding, and usage of scripture that corresponds to the timing or mistiming of grace, be?

\section{A timed text ...}

Let us start out by stating the obvious: The Bible is an entirely human word, i.e. a book like any other book, literature like any other literature. 'The Bible is timed historically', did not fall directly from heaven, and was not written by angels. On the contrary, it was written by humans, by a number of historically proven figures (and, if not historically proven, yet by people), who, with their own individuality and grammatical skills (or lack thereof), their characteristic styles of writing, choice of words and perceptions, left us the 66 books of the Bible. In these 66 books, we also find a rich variety of genres, literary strategies and narrative developments. The Bible literally teems with true humanity and the writers' true creativity - all linked to historical epochs.

Because of this and, inter alia, because of the humanity of the perceptions and interpretation processes, quite a few 'apparent factual contradictions' are evident in the Bible (e.g. the often-divergent ways in which the synoptic gospels report on the life, death and the resurrection of Jesus). At a first reading, it appears as though certain narratives just do not tally with other narratives on the same events. Does this mean that suspicion must be cast on the historical event 'as event'? That the 'factual reality' as undergirding of, for example, the Jesus narrative is involved? No, but indeed that the 'interpretation processes' of these events and facts were done by humans. ${ }^{1}$

This of course implies that the Bible - should we wish to read it in a responsible manner - should be studied with the assistance of historical and linguistic sciences. Sciences that examine the social backgrounds of the Bible (the so-called world 'behind' the text), the literary nature of the text itself (the world 'in' the text), as well as the history of the workings and interpretation of the text (the world 'in front of' the text; for a summarised discussion, cf. Smit (1987:26ff.). 
'The words of the Bible contain no magical power, as such.' The Bible's letters do not glow in the dark. They are ordinary letters on paper, printed in ink, according to prescribed (human) printing processes. Stated more dogmatically: God's revelation is greater than the Bible, also precedes the Bible. The Bible is but the record of God's revelation and humans wrote this record. In short, the Bible is not God or God's revelation, and therefore may not be shifted near to, or in the place of God to become an object of worship. ${ }^{2}$

There is something extremely liberating in the fact that Scripture has a human dimension. (It namely underlines the fact that God speaks in human language.) That God literally, and 'by way of speaking', has come and entered the brokenness of our human language. In fact, we could say that the Word having become Scripture (the Bible) is as great a miracle as the Incarnate Word (Jesus). The 'motive of the incarnation' (humanising) is also fundamental to the book that we call the Bible - it underlines the 'condescending nature of God's revelation'.

John Calvin often wrote about God's adaptation to humans. According to him, this concerns the pedagogic motive for the economy of grace: we would not have known God if God did not stoop down to us and speak to us in such a human way that we could understand God and could know that God is near to us. God's Word does not fall from the sky in a secretive way, but comes to us in conceivable concepts, grammar and words. Because of the weakness of our ability, God speaks within the limits of our capacity. In the words of Calvin: "Because our weakness cannot reach his height, any description which we receive of Him must be lowered to our capacity in order to be intelligible. And the mode of lowering is to represent Him not as He really is, but as we conceive Him."3

\section{A timing text ...}

Let us now turn the coin around. 'The Bible is not only a timed (historical) book; it is also a timing book, i.e. a book that talks about past and future in such a way that the present is revealed as the now of the presence of God. In the terminology of this book: The Bible pre-senses God, i.e. indicates that God is Present in the present. In this sense, the Bible is different to any other book, different than any other literature.

\footnotetext{
2 The so-called Bibliolatry; for an extensive discussing of some of the ways in which Scripture already has been judged and interpreted, cf. Vaessen (1997:36ff.).

3 Calvin, McNeill and Battles (1960:1(17):13, 1(11):3, 2(11):13, 2(16):2).
} 
Throughout history many people experienced this now of the presence of God, through reading and studying the Bible. Well-known figures such as Augustine, Luther and Barth, had a pertinent experience with God that emanated from specific scriptural pericopes - and the cloud of witnesses in this connection could, without doubt, be increased vastly. Indeed, the Bible is an instrument by which God gathers, defends and supports the church by means of God's Word and Spirit. ${ }^{4}$ The notion of a timing text underlines the fact that the Bible has a dynamics of its own; that it not only witnesses about, but also brings about, downpours of grace, manifestations of manna, moments of Kairos, and experiences of Pleroma. ${ }^{5}$

The biblical words do not glow in the dark. They can, however, cast a glow over even the darkest 'times like these'. In this regard, the particular contributions of Ernst Lange come to mind again. ${ }^{6}$ For him, the listener to the sermon was of fundamental importance, but also the Biblical text, given the fact that the listeners are pictured in the text as being before God (coram deo). Furthermore, preaching talks to these listeners about their lives in the light of the Christpromise, 'as it is witnessed to in Holy Scripture.?

One of his famous beliefs was that we should not fall prey to 'resignation'; we should rather practise prosignation - putting the signs of hope as far ahead as we possibly can. ${ }^{8}$ According to Lange, we should never accept that this world cannot be changed into a better place, and in order to work towards this, preaching should prosignate, instead of resignate. This act of prosignation does however not mean losing sight of the present; on the contrary, it fills the now, the present, with new meaning. 'Resignation' allows the present to be swallowed up by the past; prosignation fills the present with the future.

Cf. The Heidelberg Catechism 21/54.

In traditional terms, this dynamic would be ascribed to the internal witness of the Holy Spirit (testimonium spiritus sancti internum). Cf. the confession by Blumhardt: "Often, when one reads a biblical word, it is like a word that definitely has not been written by humans, like a word that separates itself from all human understanding, and it is enclosed in a cloud of godly power, of godly action. Then it enters our hearts, and we cannot understand that something like this could be possible. We could not understand it at all, nor believed that it by any means would be worthwhile to still read the Word, because we know it so well, already from our school days. And suddenly such a word comes to us, like a stronger, mightier angel, who stirs our hearts with a holy hand, and our body and soul are opened, and we breathe something of a heavenly Word, of the Word that does wonders, wonders to our heart, wonders in our emotions, in our thoughts, wonders in all that we are." Blumhardt (1991:11ff.).

6 See the discussions in Chapter 3 as well as the excellent discussion on 'Lange' (Gräb, 2013:46ff.).

7 See the discussions in Chapter 3.

8 "Man resigniert nicht, man prosigniert - man setzt die Zeichen der Hoffnung so weit vor, wie man es irgend verantworten kann.” Lange (1968:33). 
Although the 'homiletical situation' that Lange had in mind has drastically changed with the changing of the times, his basic point of departure still holds true: scripture is meaningless, if interpreted by the congregation as such. In preaching, a type of congregational-hermeneutical cycle is necessary, without which the preaching of hope is not possible. But - and this would be Lange's long-held conviction - the congregation should understand the sermon as a 'phase in the dialogue of believers', a dialogue in which the theologians must be the listeners, the ones being taught and being questioned, before endeavouring to give answers from their tradition (inclusive of interpretations of the Bible) - the latter again being tested in dialogue, whether they are in fact relevant for the situation at hand. ${ }^{9}$

For Lange, the preacher cannot gain his or her testimony other than in the interpretations of biblical tradition. But the crucial question is: what 'relevance' does these interpretations in fact have for the homiletic situation? The homiletic situation cannot be clarified by the preacher simply 'repeating' his or her understanding of the tradition of interpretation. In fact, depending on the extent that preachers 'participate' in the situations of their audiences, and to the extent that they participate in the understanding of the community, the preacher's understanding of the Christian faith could fall into crisis, or at least become subject to the suspicion of irrelevancy.

That is why preachers need the Bible, need the pericope, need the individual biblical text. The text not only has the ability to question that which has become self-evident, or that which now stands in doubt, but the text also allows the audience to keep a critical distance to the testimony of the preacher, calling on him or her to test their own utterances, homiletic ideas, formulas, images, and judgements regarding the relevance or irrelevance of their choices in transmitting aspects of their tradition. ${ }^{10} \mathrm{It}$ is, according to Lange, in this reciprocal, communal process of dialogue, that hope, literally, springs forth - as prosignation.

Let us return for a moment to our discussions about improvisation and synchronization. ${ }^{11}$ Perhaps these concepts underline what Ernst Lange intended to achieve through his advocacy of congregational participation in and of the homiletical situation. In order to make this participation possible, preachers

\footnotetext{
9 "Die Kirche soll die Predigt als eine Phase im Gespräch der Glaubenden verstehen, in dem die Theologen lange Zeit die Hörenden, Lernenden, Befragten sind, um dann Antworten aus der Tradition zu geben, die wiederum im Gespräch auf ihre Relevanz zur Sache zu prüfen sind." Cf. Lange (1976:30).

Cf. Lange (1976:29,42).

See the discussion in Chapter 2.
} 
need to have a fundamental knowledge of scripture, but also of the congregation. Synchronization is needed to foster the dialogue between these two forms of knowledge, and improvisation to know when to do this. In a sense, this process resembles the putting together of an act on stage, i.e. to facilitate the 'performance' on stage - the performance of the preacher, the congregation, but also the biblical text. It calls for a special kind of 'setting-in-scene' of all the role players. ${ }^{12}$ This setting-in-scene does not equal one, 'correct' performance of the text, not simply a repetition of this text, but rather the coming together of a corpus of strategies, to create something new. ${ }^{13}$

But this already brings us to the notion of:

\section{Timing the text ...}

The tension between the Bible as a timed (historical) text, and a timing (not bound to historical fixation) text, calls for the (hermeneutical) act of timing the text. Preachers are called upon not to repeat the text, but to time the text, i.e. to find, and point towards, the connections between the text and the 'homiletical situation. This is what I earlier called 'timing as linking and connecting. But the hermeneutical act of preaching also entails 'timing' as intersecting, i.e. preaching about past, present and future in such a way that the overlapping of the times become evident - resulting in the 'interruption', by grace, of the 'now.'14

Let us return to the question posed above: What would the characteristics of such an understanding, and usage of scripture that corresponds to the timing or mistiming of grace, be? I briefly outline three possible features:

First, the Bible is approached as being 'multi-voiced', and 'multi-layered'. This means that preachers cannot exhaust the fullness of Scripture with a single sermon or method of preaching. In fact, preachers cannot, and should not perceive their sermons to be a final product that is completed like an article for the market; rather as a process, a development that has many points of contact, inclusive, with open arms. A sermon is not a product, not a final finished-off speech, $100 \%$ correct. On the contrary, sermons may have, and

12 The German version of this would be 'Inszenierung', a concept not easily translatable. It has found its way into a number of German works on preaching, for instance Nicol and Deeg (2012:68-84); and Plüss (Charbonnier, Merzyn and Meyer 2012:19-136), to name but a few.

13 See Plüss (2012:119ff.).

14 See the discussion in Chapter 1. 
even should have 'linguistic gaps' in them, areas that are open for further thought and interpretation. ${ }^{15}$

In this sense, the objective of preaching is not to convey unassailable certainties, but rather to open new perspectives on these so-called certainties, a new imagination 'to picture, portray, receive and practice the world in ways other than it appears to be at first glance when seen through a dominant, habitual, unexamined lens. ${ }^{16}$ For this, a responsible, hermeneutical communication with the biblical text is indispensable: it offers the source that cannot, and should not, be diminished, smothered, eradicated or dimmed by our stereotypes.

The patriarchal, hierarchical, authoritarian and monologist style that characterised so many sermons, and still does, has little understanding of the multi-voiced, and multi-layered character of scripture, as well as the preferability of a redistribution of past interpretative privileges. One of the consequences of this style of preaching was the fact that it (unconsciously?) contributed to a kind of solidification of God-images that domesticated the richness of biblical narratives according to certain stereotypes. ${ }^{17}$

Biblical texts, on the contrary, question the stereotypes of our status quo's in a subversive way by playfully, and enticingly suggesting other possibilities. This penetrates the type-casted, fixed formulae, the boredom of dead habits, the mere repetition of finished and undisputed truths that no longer are a threat or challenge to the listeners. Biblical texts contest a diminution of its own inherent wealth, against adaptation and fitting into the national moral of religious people, against a reduction to something that pious people can handle. To preach, is to listen to the many sounds of the text, to dance to the variety of tunes of the text. Too often we want to harp only on our own, solitary string ...

Second, the fact that the Bible is multi-voiced and multi-layered, does not mean that preachers should side-step or ignore their responsibility to approach the Bible 'in a scientific-holistic manner.' On the contrary - there is no way in which we can preach imaginatively and relevantly without a fundamental and faithful communication and 'work' with the biblical text.

Preachers may never hide behind a certain view of the Bible as the infallible Word of God' and use this as a shibboleth for being lazy. To preach implies

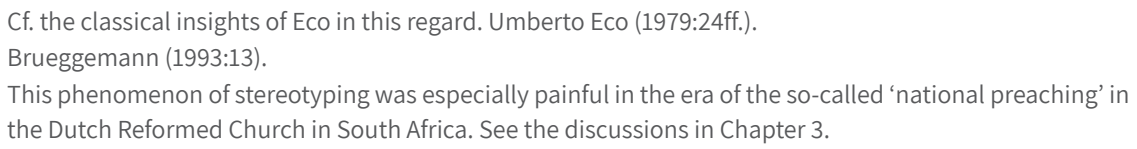


hard (scientific, linguistic, exegetical, and hermeneutical) work on the text. But, in this sense, it also is a voyage of discovery; it presents the possibility to repeatedly discover new dimensions in the text, to examine new worlds. This would not be possible without the scientific work on the text as a human document. Preachers simply do miss much if they operate with a scriptural view that makes them hesitate to work truly with the text as a linguistic phenomenon - even though this hesitation often originates from a certain respect for Scripture's 'Godly nature'.

It could be said with some certainty: if the scientific work on the biblical texts is neglected, the result almost always is, by default, not only irrelevancy, but also religious activism (moralism), accompanied by cliché. ${ }^{18}$

The flipside could, however, also be true: when working with Scripture, scientific methods may become so critical and destructive that preachers lose their trust and expectation to hear the many voices of the text, even God's voice, speaking from the linguistic folds and textures (texere) of the text. To preach, one needs scientific methods, but you do not preach scientific methods. If the voices of the text are not heard in the sermon, then it is not preaching: 'Sermons not informed and inspired by Scripture are objects dislodged, orphans in the world, without mother or father.'19

Third, the timed text and the timing text calls for timing of the text, i.e. 'synchronization and improvisation'. We have noted earlier that improvisation can only take place on the grounds of certain fundamentals, i.e. the theories of music (or whatever the field would be), and the experiences of habitual practise.$^{20}$ It is only on this basis, that the freedom of improvisation can come to fruition. In terms of what was said above: it is only based on a scientific approach to the scriptures, inclusive of an openness for the multi-voiced and multi-layered character of the scriptures, that the freedom of improvisation can, and in fact should be, dared.

Improvisation calls for interpretation, and interpretation means that, based on your (scientific) work with the text, you say what is 'not' in the text. Again, in terms of the terminology of improvisation, you sense 'in what direction the music (text) is headed'. You do not preach methodologies or theories about the text, but endeavour to point towards the space and time ('situation') to which

See the discussion in Chapter 3.

Craddock (1985:27).

See the discussion in Chapter 2. 
the text is headed. This is indeed a complex art but cannot be avoided in the act of preaching.

This implies, inter alia, that no two events of improvisation will be the same - given the fact that time and space are in constant flux. This also does 'not' mean that all preaching should be hitched to the sensationalistic news of the day. Improvisation does not serve sensationalism. On the contrary, it is an art that connects to the deeper fibres and movements of life; to that which is existential to being human.

This brings us back to the notion of 'synchronisation.21 Preaching represents a process in which the biblical text (which is always a timed text), is brought into sync with the situation of current space and time.

A truly gripping aesthetical example of synchronisation can be seen in the work of Steve Reich (one of the founders of so-called 'minimal music'). Minimal music has some connections with minimal, even post-minimal art. ${ }^{22}$ Reich often starts his musical pieces with what could be called 'phase'-techniques - two musicians listen to the same performance (in some cases, Reich in fact uses real sermons in this regard) on two separate tape-recorders, and then they slowly start making music 'out of sync'. This 'out of sync' creates a unique spatial and temporal experience. The process does however not stop there - the two musicians slowly move 'into sync' again, and this process of 'moving out of' and 'into sync' represents music stripped of cliché and kitsch, indeed expresses minimalistic music in its bare essence, 'here and now.23

In an interesting tape piece, entitled It's gonna Rain, Reich uses a phrase from a real sermon on the Biblical flood, and uses the 'phase-shifting/phasing' technique referred to above, which he describes as 'a musical technique to generate a variety of sounds by gradually moving the cycles of two or more repetitive patterns in and out of phase. ${ }^{24}$ Perhaps we could say, in terms of this book, that this process of phase-shifting exemplifies the in-between spaces in which preaching takes place: moving constantly between the 'times we live in', and the 'times of Kairos'. In this in-between-space-and-time movement, preaching 'slows down' time, and 'expands' space - by pointing out where

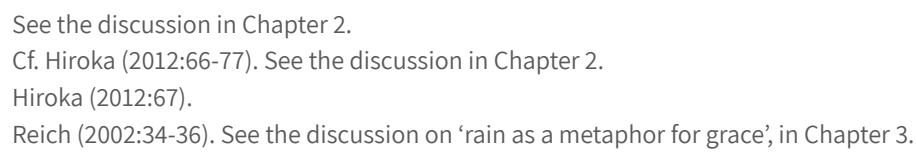


time and space are headed, and with what time and space are in fact already inundated, namely 'grace'. Steve Reich says this better than any homiletician can:

Performing and listening to a gradual musical process resembles: pulling back a swing, releasing it, and observing it gradually come to rest; turning over an hour glass and watching the sand slowly run through it to the bottom; placing your feet in the sand by the ocean's edge and watching, feeling, and listening to the waves gradually bury them. ${ }^{25}$

In a particularly striking piece of video art, entitled Phase to Face, Reich introduces two female dancers, starting their movements in sync, accompanied by music, and then gradually moving out of sync, following the cue of the music, which also gradually moves out of sync. ${ }^{26}$ Both the dancers cast primary and secondary shadows against the wall behind them, and together, they create a combined, darker shadow between them. The latter represents the space and time of their being 'in sync'; the other shadows points towards their state of being 'out of sync. The dramatic - aesthetical effect is intensified by the constant movement of the dancers, and consequently, also their shadows. The darker, shared shadow also moves, an indication of the fact that this time and space of being in sync is never solidified, is perpetually in flux, and, in terms of its shape, dependant on the movement of the dancers. The following 'still photo' does not do justice to the beauty of the moving scene, but serves as an indication thereof: ${ }^{27}$

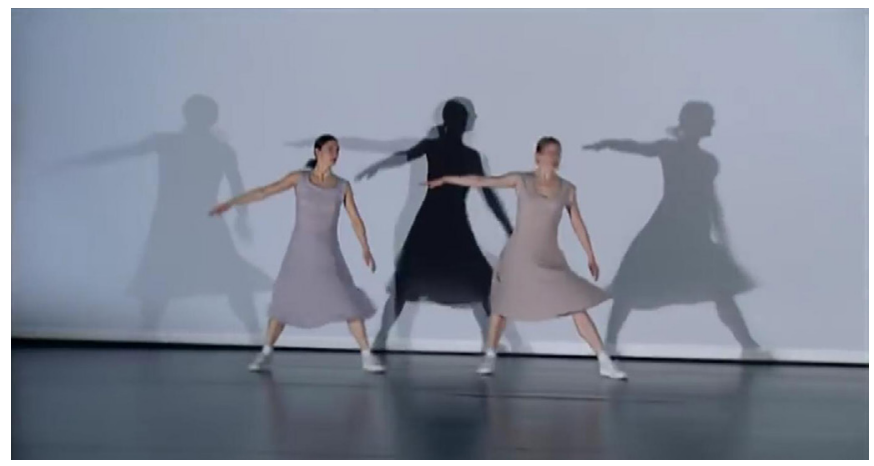

Figure 6.1 A screen shot from Steve Reich's video, Phase to Face with John Cage and Philip Glass (Euro Arts Channel, 2018)

Reich (2002:34).

EuroArtsChannel (2018) and shorter video: BBC (2015).

See the complete composition: BBC (2015). 
If one uses this atmospheric picture of the dancing women as a homiletical paradigm, it should, however, not lead to a romanticising of the preaching event. Earlier, I stated that the synchronisation of grace always implies an interruption by grace. ${ }^{28}$

The biblical text offers an interruptive, albeit salvific word, a word with an abrasiveness that penetrates the one-dimensionality of our world to surprise, to provoke, reveal - with a view to enter a new world: accepting and living an alternative. This act of synchronised interruption is an imaginative, creative event: it breaks down the dyed-in-the-wool comparisons with which we live, opposes the status quo of all ideologies and all -isms that bound us and still bind us, to point out other possibilities, and so simultaneously ('synchronically') create unsought and unthought of possibilities. Interruption shocks, but it shocks to unlock gateways, to open panoramas, to remove some veils from the murky moments of life.

\section{... or taming the text?}

When, however, this interruptive element of the text is sidestepped, or muzzled in any way, the text is not timed, but tamed. This taming of the text can take on many forms. The first, most obvious version thereof would simply be the fact that large portions of the Bible are not read (anymore), even less preached on. This is true concerning more 'difficult' or 'uncomfortable' texts, i.e. texts that do not fit smoothly into our theological, homiletical, or ideological schemes.

The usage of moralistic structures in preaching probably represents the 'most common methodology of text-taming. ${ }^{29}$ Some of the typical characteristics of moralism are either a dehistorizing of the text (i.e. dealing with the Bible as though it is a timeless, a-historical collection of words and truths) with concomitant phenomena such as allegory, cliché, etc. ${ }^{30}$ Another approach would be the anthropologising of the 'theological gravitas' of Scripture, viz. changing the merciful acts of God into moral appeals for self-improvement Instead of the Gospel, sermons like these offer a list for controlling the inner quality of religious hygiene. ${ }^{31}$

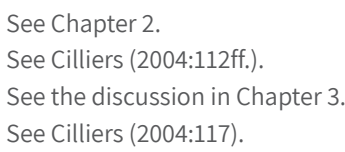


Fundamental to preaching is the question: What is a (biblical) text? We could say: each text is a window that opens a unique vision of God's face. Even more: each text is a multiplicity of windows, a kaleidoscope of insights, of new perspectives onto God's face. As already emphasised, texts, as such, contain more than one truth about God; more than a single interpretation, therefore, this is not only possible, but also inescapable that our God-images are preached (constructed) in order to be (simultaneously) deconstructed. ${ }^{32}$

If one reads a text with the view to distilling a single, 'eternal truth' from it, you run the risk of diminishing and ultimately taming the text. If you are satisfied to discover but one diamond in the digger's sieve of exegetical work, then you have not dug deep enough in the mine of the text. Or, if you just continue staring at one side of the diamond, and do not continue turning it around in preaching, you will never experience all its sparkle. Apparently, a good text in the hands of bad people can become a bad text, and a bad text in the hands of good people a good text. ${ }^{33}$ Even a so-called 'bad' (difficult, uncomfortable) text, when timed hermeneutically, and not tamed moralistically, can become a 'good' text, and vice versa!

I reiterate that texts perpetually interrupt our comfortable, tamed take on these texts.

As does the following ... 


\section{Sermon: On the Cutting \\ EDGE ... OF GRACE}

The Word of God is alive and active ...

Hebrews 4:12

In his classic book, The Brothers Karamazov, Fyodor Dostoevsky tells the story of a man that had been living with a terrible secret for fourteen years, hidden deep inside him - a secret that was gnawing away at him, day after day. In an insane moment in his life, he had shot and killed another man, out of jealousy. Because of certain circumstances, nobody has ever discovered who the murderer was.

However, after fourteen years, this man decided to share his burden with Sossima, one of the characters in Dostoevsky's story, telling him about this lie of his life, to rid himself of his old bloodguilt. During one of his visits, Sossima asks him to read Hebrews 10:31: "It is a dreadful thing to fall into the hands of the living God ..."

The man read this passage of Scripture, became dead pale, and slung the Bible away from him. His whole body was shaking, and he cried out: "A terrible verse ... truly, you have chosen this well. For fourteen years, I have been falling into the hands of the living God, every day. Now, again. Tomorrow I will pray that I may be finally liberated from these hands."

The hands of the living God - a space for condemnation, not grace? The hands of the living God - not holding us for our salvation and comfort? Rather to be tormented and in the end, perish?

Yes, there are texts in the Bible that can leave you pale and shaken; texts that shock and interrupt you so much, that you want to throw the Bible away from you, as far as possible. Like, for instance, Hebrews 4:12-13. I made a short list of what some scholars had to say about this text. It is like a bright light that blinds you, one said - so bright that you must cover your eyes with your hands when you (try to) read it. It is like an X-ray that shines straight through you, making 
you transparent, revealing the malign growth, another commentated. Like a surgical scalpel that cuts you open, to reach this cancerous intruder, another added. And so on ...

This text is indeed - as the text itself states - like a sharp 'sword', cutting to the bone, and deeper, wherever it strikes. In the Bible, a sword is often used as metaphor for judgement, for example in Revelations 19:11-21, where we hear of the Rider on the white horse - Christ - and, 'out of his mouth came a sharp sword with which He defeated the nations..$^{34}$ This is no picture of a Baby Jesus, meek and mild, surrounded by gentle, dear little angels - on the contrary. What we hear here is not a harmless word, filled with dripping sentimentality; rather a terrifying, revealing, wounding Word - 'about' the Word.

It is as if the author cannot find enough terms to express exactly how deep this Word cuts into our lives: 'For the word of God is alive and active. Sharper than any double-edged sword, it penetrates even to dividing soul and spirit, joints and marrow; it judges the thoughts and attitudes of the heart. ${ }^{35}$

Where 'this' Word sounds, the bulwarks fall away, the hidden agendas and secret motives are laid bare in their finest detail, and the darkest depths of our lives are turned inside out. After all, this is the Word of the living God, the Word of all words, calling us to account: 'Nothing in all creation is hidden from God's sight. Everything is uncovered and laid bare before the eyes of him to whom we must give account. ${ }^{36}$

We would rather bypass this verse. Surely, it cannot be the best of best experiences to be cut open by a sword. I once saw a Bible in which only the comforting promises where printed in red, making them stand out. Of course, it is nice that all of this could be printed so beautifully in red, and of course, we cannot read the comforting promises of the Bible enough - but what about the rest of it?

What about the 'historical backgrounds' of these promises, related to events that often speak of our sin and God's judgement? What about texts that could terrify us? Or do we believe that such texts do not exist? Do we only want to read, neatly abstracted from the Bible, '365 Beautiful Promises, one for Each Day of the Year?' Are we searching for a religious experience - in the words

\footnotetext{
Revelations 19:15.

Revelations 19:12.

Revelations 19:12-13.
} 
of Leonora Tubs Tisdale - that no longer entails saying 'Holy, Holy, Holy', but rather 'Nice, Nice, Nice'?

If we are, we can no longer say we listen to the Word of God, the 'whole' Word, and 'nothing but' the Word. Then we miss out on this Word, also including Hebrews 4:12-13, and all other uncomfortable and interruptive verses in the Bible, that we urgently need to hear ...

So, what do we do with this Word? Throw it away?

Well, strange as may seem, the author of this text starts to sing about this text! Or rather, he sings this text. Hebrews 4:12-13 took its cues from, and was written in the form of, an ancient Christian hymn, complete with beautiful parallelisms and two or perhaps three finely structured verses. One could just imagine what type of music would be best suited to accompany these lyrics ...

Apparently, the author believed that the Sword of the Word, with all its cutting capabilities, was something worth singing about. Imagine being cut open, but, at the same time, opening your mouth to sing the praises of the precision of the Scalpel doing it; imagine 'being on the cutting edge', and extolling the dreadful dissection being performed of your body, soul, and spirit ...

Why sing the text, instead of flinging it away? Apparently, the 'Good News of the Gospel' is not possible, even thinkable, without this exposing, cutting edge of the Sword of the Word of God. After all, we are not saved from 'nothing', but from our sins, our rebellion, our pride against God. Our sin is not just a small and irrelevant issue that we can be liberated from as easily as making a cup of tea - it is indeed a cancerous reality that needs to be removed from us, through divine intervention. We do not reach salvation by means of some comfortably arranged exchange agreement between us and God, but rather through God's judgement, without us being able to take short-cut routes, or by offering so-called valid excuses. No, we go under; we are taken into, the depths of God's judgement ... before we can experience the light of grace.

This is exactly why the author of Hebrews places this sharp word about the Sword at this point in the flow of his argument. He wants to make sure that his readers will not miss out on the opportunity of 'entering God's rest' (which he describes in detail in the preceding verses). He does not want them to be left out of the fullness, the Pleroma, to which the whole of creation is ultimately headed. He does not want them to mistime grace ... 
It would seem from his writings, that this was exactly the danger threatening his readers: that they had begun to give up on the marathon of faith and was beginning to fall behind from grace. Their whole faith was indeed in danger of being consumed by the malignant growth of sin, in the form of indifference.

Let us concede: Not only the faith of the readers of these ancient Scriptures, but also our faith, is often under siege, more than we could imagine. Our faith is being threatened from all sides, whether we know it or not. It could be because we have become lukewarm or lazy, tired or dispirited, filled with fear or frustration. It could be something that slowly crept over us or invaded our lives in the blink of an eye, in broad daylight. The end-result of all of this in in any case that we stop fixing our eyes on Jesus, the Pioneer and Perfecter of our faith. ${ }^{37}$ Then it is time for the X-rays to shine through us again, revealing what is wrong; time for the Scalpel to dissect us, time for the cutting edge of the Sword to do its work.

If, at this stage of your life, you are of the opinion that God is acting too stern towards you, you should know: God does this because God loves you. If you think that God's Word is too sharp for you, seemingly cutting you up, you should know: God does this because God cares. If you are under the impression that God has become silent as far as you are concerned, listen again: God is talking. Do not lose heart. Within God's Word of judgement is already included God's Word of salvation.

Sören Kierkegaard prays, as follows:

Father in heaven! You speak to humans in many ways: You, to whom all wisdom and intellect belongs, You wish to make Yourself conceivable to us anew. Oh, and also when You remain silent, then You still indeed speak to us; because also He who speaks sometimes remains silent to give his students the opportunity to have their say; also He that speaks sometimes remains silent to test his beloveds; also He who speaks sometimes remains silent to make the moment of understanding so much more profound when it comes. Father in heaven, is this not so? Oh, the time of silence, when a person stands alone and deserted, because we do not hear Your voice, then we feel that the separation will be forever. Oh, the time of silence, when a person thirsts in the desert, because we do not hear Your voice, and it seems as though we have been entirely forgotten! Father in heaven, then it is but a short pause in the coherence of the dialogue between You 
and us. So, allow this also to be blessed, this silence of Yours, like every word of Yours to us. Do not let us forget that You also then speak, when You are silent; give us this consolation: that you remain silent out of love, just as You also speak out of love, so that now, whether You are silent and whether You speak, You are still the same Father, who acts with the same Fatherliness, whether you now lead us through Your voice, and whether You now teach us with Your silence.

Do we see this anywhere better than when standing next to the Cross of Christ, where we hear the cries of the Crucified: 'My God, my God, why have you forsaken me?'38 What is the Cross other than the judgment of God? A broken Body, spilt blood - what is that, other than the dreadful result of falling into the hands of the Living God? Other than the terrible outcome of God's Sword sweeping down on God's own Son? In that moment, our eternal High Priest (about whom the author writes extensively in the verses following these verses) not only brought an offering on our behalf, but He Himself became the offering. Here, the Sacrificed, Crucified, did not try to avoid God's judgement, but rather took it upon Himself.

Therefore, and for no other reason, the Cross signifies, simultaneously, judgement and salvation. In this judgement, God's grace is already hidden away; rather, in this judgement, God's grace is revealed as true grace.

The man in Dostoevsky's story was right: it 'is' dreadful to fall into the hands of the living God. However, he was also completely wrong: in no way are we liberated 'from' these hands; rather, we are liberated 'within' these hands.

The hands that cut through us with the Sword, are the same hands being nailed to a piece of wood.

Therefore, we are on 'the cutting edge ... of grace'. 


\section{Chapter 7 \\ FULFILLING TIME}

\section{Africa: Timing the Event}

"You (Western people) have watches; we (African people) have time." This piece of folklore, mostly spoken tongue-in-cheek, has often resulted in either mirth, or irritation. ${ }^{1}$ Does this, for instance, imply that Western people are (always) on time, i.e. always punctual (in line with German Pünktlichkeit'), and that African people are always late, missing 'deadlines', frustrating any attempt at timely 'organising' an event? Or is it simply a way of saying that African people are not driven or mastered by any notion of 'time'? Does the piece of folklore in fact articulate a more fundamental divide between Western and African understandings - and experiences - of time?

Few African scholars have contributed more to the discussion of 'African Time' than John Mbiti, whose work has, on the one hand, been described as 'the classic expression of African philosophy'2, but, on the other, has also become contested and at times even highly controversial. In his book, African Religions and Philosophy, published in 1969, Mbiti argues that Africans indeed have notions of time. According to Mbiti, African understanding of time is 'event-orientated rather than mathematically-calculated. ${ }^{3} \mathrm{Mbiti}$ is of the opinion that "Time as separate [entity] does not 'move'; only events come and go ..." His concern indeed seems not to be with 'Western notions of abstract time which can be measured apart from events. ${ }^{5}$

This event-orientated approach does have certain consequences for Mbiti's use of the (traditional) terms of 'past, present, and future.' According to him 'past events' serve as markers for, and of time. Looking 'backwards' from the present, decisive events in the history of a community is seen as events that shape, or at least situate the present moment. 'Now' can only be understood in the light of 'then'. The past is described in terms of events: 'In the time of the

\footnotetext{
The expression probably originated from Kenia. What follows, is a revised version of Cilliers (2018:113-132). Wiredu (1991:88).

Mbiti (1990:15-28).

Booth Jr (1993:84) quoting Mbiti.

Booth Jr (1993:84), quoting Mbiti.
} 
great drought of 1954 ..., 'In the time of the floods of 1917 ..., etc. And, because the future does not (yet) contain events, the future cannot be understood as a long period - rather as short and foreseeable, stretching to six months and not beyond two years. ${ }^{6}$ It is rather the significant events of the past that define the present reality and tomorrow. In the words of Mbiti himself:

The linear concept of time in western thought, with an indefinite past, present and indefinite future is practically foreign to African thinking. The future is virtually absent because events which lie in it have not taken place, they have not been realised and cannot, therefore constitute time ... 'Actual time' is therefore what is present and what is past. It moves 'backward' rather than 'forward'; and people set their minds not on future things, but chiefly on what has taken place. ${ }^{7}$

Contrasted to the notion of actual time, Mbiti speaks of potential time - that which lies in the (near) future, and which falls '... in the category of inevitable or 'potential time ...' The most significant consequence of this is that, according to traditional concepts, time is a two-dimensional phenomenon, with a long 'past', a 'present' and virtually no 'future.8 What lies beyond the immediate (inevitable) future, could be described as 'no time' (see diagram below).

Mbiti's understanding of African time relies heavily on the Kiikamba 'tene period' or Kiswahili word, Zamani (originally Arabic) 'as the centre of gravity in the Akamba conception of history: people's history and thinking and understanding of the world are oriented toward this finality ... ${ }^{9}$ He outlines his conception of the present using the notion of Sasa, (which could roughly be translated as 'present'), but which is embedded in the 'past' as Zamani. Events take place within the Sasa dimension, before moving 'backwards' from Sasa into the Zamani. ${ }^{10}$ In a sense, Zamani is the beginning and end of everything. But, although being two dimensions of time, Zamani and Sasa are not separable. There is a reciprocal feeding into one another. Therefore, for instance, the ancestors are not absent in the present, but rather contemporary. ${ }^{11}$

Although it is not that easy, or even appropriate to define Mbiti's understanding of African time in exact terms, and although one runs the risk of again

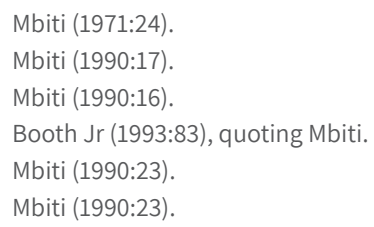


interpreting him according to Western (i.e. linear) constructs, I propose that we depict this understanding of time as follows:

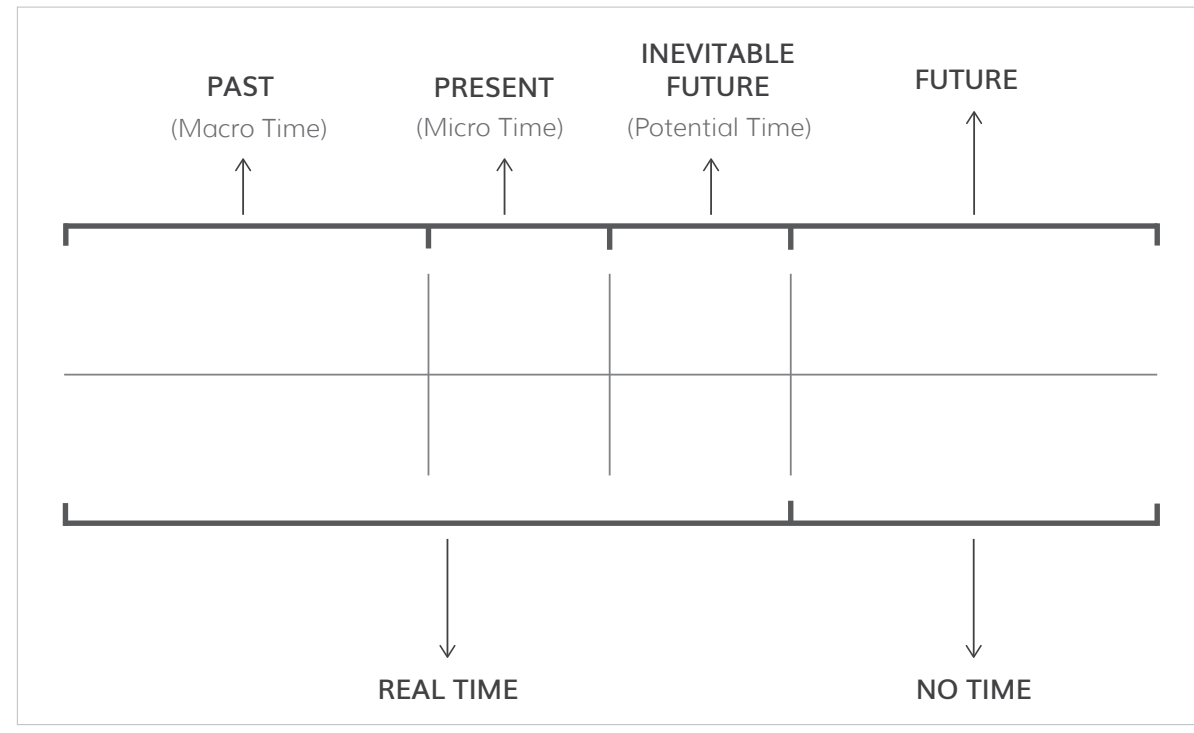

\section{Figure 7.1 A Depiction of John Mbiti's understanding of African time by Johan Cilliers}

Sasa (the present) is a complete time dimension - having its own short future, dynamic present and an experienced past. This is called micro time. Zamani is more than just 'past' - it also has its own 'past', 'present', and 'future.' This could be called macro time. ${ }^{12}$ Zamani is the point beyond which nothing can go - it is the 'graveyard' where all time and all events find their halting point, a type of final storehouse for time; the ocean of time in which everything is absorbed into reality. ${ }^{13}$ In effect, Zamani is used to describe 'the stretches of time into timeless eternity.' ${ }^{14}$

According to this African understanding, time rather moves from present (Sasa) to past (Zamani), and not so much from past, to present, to future. Sasa is about that which is of immediate concern for people; it stretches into a relatively short future; it swallows up so-called 'future'. Past and present overlap and the present is swallowed up in the past; past and present come to rest in the graveyard of time. The present exists to serve the past, which in turn gives purpose to the present. In short: the present does not so much

Babalola and Alokan (2013:143-147).

Babalola and Alokan (2013:145).

Babalola and Alokan (2013:147). 
influence the future, as it serves the past. The difference with Western time would then be that the so-called Western 'future' extends much further than the African 'future.' 15

Some critics of Mbiti have stated that he practises a type of 'reversed teleology', in which time is conceived backwards. But this critique is indeed only valid if 'time' is indeed understood as a linear unfolding of past, present, and future - which could be measured (mathematically) in terms of seconds, minutes, hours, days, etc. Only if one evaluates Mbiti's understanding of time from this linear, temporal-mathematical perspective, one could say that his African concept of time is the 'mirror opposite' of the West. ${ }^{16}$ Of course Mbiti knows that Western and even certain Biblical concepts of time mostly operate with a linear perspective, but regarding the latter, he concludes that 'though widely accepted as the only scriptural one, [it] is not the only valid one, but that the two-dimensional concept of time is equally valid. ${ }^{17}$

This idea of 'actual time' and 'potential time' - Mbiti's so-called two-dimensional (or: dyadic) concept of time has however been criticised as not being representative for the whole of Africa. ${ }^{18}$ African understandings of time - as understood by Mbiti, amongst others - has indeed changed with the coming of the Christian missionaries to Africa - the latter exposing African temporality to a more linear take on time..$^{19}$ Especially Mbiti's postulation of African time as being short on future has come under critique. It has for instance been pointed out that in the 'house-rules' of the old Oyo Kingdom of the South West Nigeria (1754-1796) there were certain checks and balances built in to prevent the monarch from being despotic or autocratic - clearly an indication that even then, Africans had a longer, more extended view on the future. ${ }^{20}$ Mbiti himself does contend that the cycle of seasons will 'continue forever ${ }^{21}$ - an indication that his own understanding of the 'future' is not that short-sighted as many would believe it to be.

Mbiti's concept of time does in fact accept the linear progression of time as one dimension, but also stresses the communal dimension, namely that time is 'created' by events within community. For him, African notions of time hinge

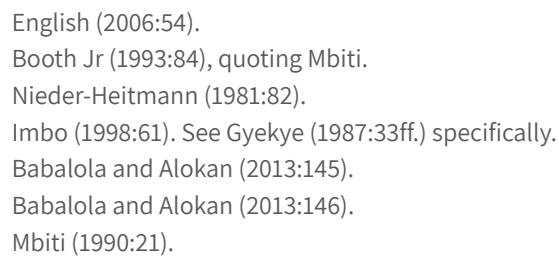


on 'the timing of event'. Time is tied to events. ${ }^{22}$ In other words, time must be experienced to become real for people, and, only the past and the present have been experienced by anyone. ${ }^{23}$ For Mbiti, time is composed of events, and events must be experienced to be real -

Time has to be experienced in order to make sense or to become real ... Since that which is the future has not been experienced, it does not make sense; it cannot, therefore, constitute part of time, and people do not know how to think about it - unless, of course, it is something which falls within the rhythm of natural phenomena.

These events are however of a communal nature and relevance: "Time is not duration as it affects the fate of the individual, but it is the rhythm of the breathing of the social group."24 Perhaps it could even be postulated that the image of a spiral depicts best what Africans understand as time - a spiral that includes both linear and cyclical dimensions - the latter inclusive of (cyclical) events such as droughts, seasons, even rituals, etc. ${ }^{25}$ As said earlier, I would concur with this notion, and call it 'spiral-communal' time. ${ }^{26}$

In my opinion, African notions of time, as for instance put forward by Mbiti, remind us of the importance of 'now.27 Could it be said that Western understandings of temporality could either become fixated with the (guilt and/or glamour of the) past, or endeavours to escape to the (planning and/ or developing of the) future? That it could in fact lose out on the promise of the presence? ${ }^{28}$

To put it in even more contentious words: there is, in fact, no such thing as the 'past' or the 'future.29 ${ }^{29}$ The past is the past (i.e. no longer there), and the

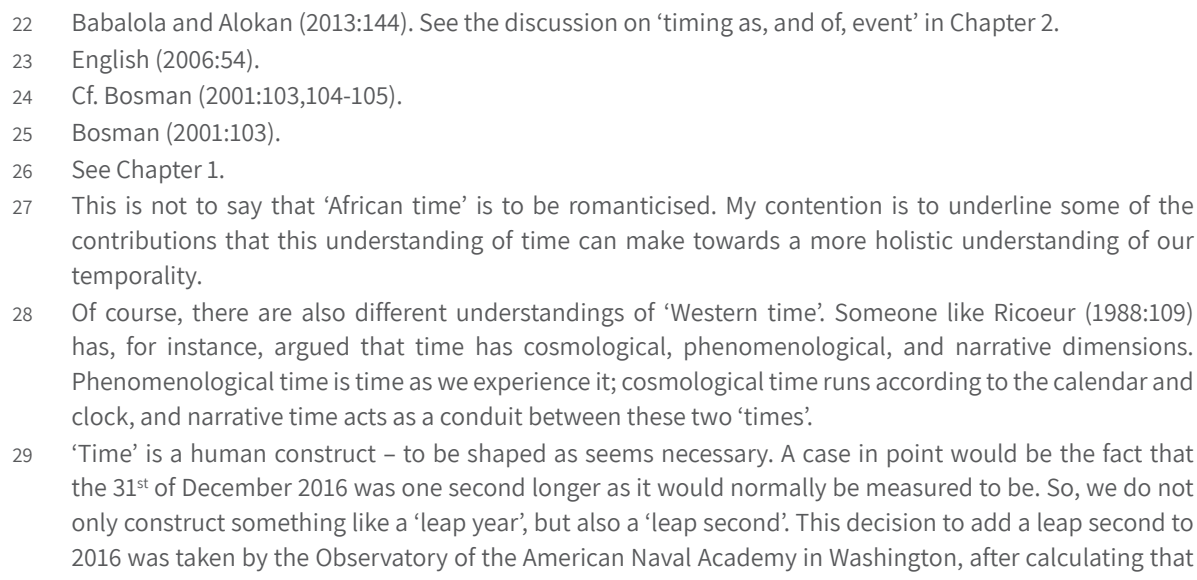
contributions that this understanding of time can make towards a more holistic understanding of our temporality.

28 Of course, there are also different understandings of 'Western time'. Someone like Ricoeur (1988:109) has, for instance, argued that time has cosmological, phenomenological, and narrative dimensions. Phenomenological time is time as we experience it; cosmological time runs according to the calendar and clock, and narrative time acts as a conduit between these two 'times'.

29 'Time' is a human construct - to be shaped as seems necessary. A case in point would be the fact that the $31^{\text {st }}$ of December 2016 was one second longer as it would normally be measured to be. So, we do not only construct something like a 'leap year', but also a 'leap second'. This decision to add a leap second to 2016 was taken by the Observatory of the American Naval Academy in Washington, after calculating that 
future is the future (i.e. not yet there). The only thing that is 'there' is 'here', i.e. now. By this, I am obviously not saying that the past never happened, or that - hopefully - the future will never happen. But we do not 'have' past or future; we only 'have' now.

This comes close to what Saint Augustine - another African! - said concerning time. ${ }^{30}$ According to him, it is in fact not correct to talk about three separated times (past, present, future). He prefers to speak about a present of things that have already happened, a present of things that are happening, and a present of things that must still happen. In his own words:

Perhaps it might be said rightly that there are three times: a time present of things past; a time present of things present; and a time present of things future. For these three do coexist somehow in the soul, for otherwise I could not see them. The time present of things past is memory; the time present of things present is direct experience; the time present of things future is expectation. ${ }^{31}$

Time is all about the connection between events (past, present, future), as experienced in the 'now' - but then this 'now' should also not be understood in the traditional (mathematical) way as being one point in time in a linear unfolding of times. 'Now' takes on a new meaning, at least within African thinking. If we follow Saint Augustine's argument, all that we have of the past are memories, monuments, sites, recordings, etc. - but we can only access them now, in the present. All that we have of the future are things like projections, expectations, hope - but likewise, we can only access them now, in the present. This 'access' represents a type of 'time-travel' in the mind and imagination, a 'time-travel' that however always takes place 'now'.

As popular as the notion of real, i.e. physical 'time-travel' might be - travelling to the past or the future - it cannot be done, at least not yet! We are (always) in

the atomic watches guarding over the 'correct' measurement of time in France indicated that a second was 'lost' somewhere - or is it sometime? So, the countdown to 1 January 2017 paused for a second (literally), flashing the number one, or the number zero twice - to 'make up for lost time'. This is however not the first time that time has been adjusted: The so-called Solar Year is not 365 and a quarter of a day, as previously proposed, but rather 365 days, 5 hours, 48 minutes, and 45 seconds. So, consequently, in our human calculations of time, time was 'lost', and the scientists discovered in 1582 that our calendars were 10 days out of step with 'real time' - whatever that may be. This meant that (the time of) spring was slowly becoming (the time of) winter in the Southern Hemisphere. The wise people decided to let Thursday, the $4^{\text {th }}$ of October 1582 be followed by Friday, the $15^{\text {th }}$ of October 1582 . So, officially, the time from the $5^{\text {th }}$ of October 1582 until the time of the $14^{\text {th }}$ of October 1582 does not exist! Did it ever? 
the now of now. What was in the past that is accessed in the present by means of memory, etc., and what will be in the future that is accessed in the present by means of hope, etc., calls for observation and interpretation in the present. In terms of the topic of this book, this process of observation and interpretation could also be called: 'preaching.'32

\section{Timing as pre-sencing: preaching the present}

Of course, the African understanding of time does hold enriching possibilities for our evaluation of the past, as well as our visions of the future, but in this book, I limit myself to a discussion of the African notion of the present. In particular: how does this focus on, and appreciation of, the importance of the present, of now, enrich our preaching? A few (perhaps paradoxical) comments on this:

'Firstly', the fullness of the present can indeed not be mathematically equated with the duration of a second, or minute, or hour, etc. Now is filled with the past and the future; it is inundated by our memories and our hopes. In preaching, 'now', although fleeting, should not be mistaken for occasionalism. 'Now' remains linked to the past and the future. The art of preaching consists, inter alia, of understanding this link; of 'placing' the present within the coordinates of past and future - indeed, 'timing as linking and connecting.,33 'Now' does not come from nowhere. In African thought, at least according to Mbiti, the present (Sasa as actual time) is inseparably linked to the past (Zamani as timeless eternity), as well as the future (as potential time).

It should however be noted that, in African thought, the notion of 'now' cannot simply be equated to the (Western) understanding of the 'present. 'Now' rather indicates the symbolic value of an event. Understood in this way, the 'present' is transposed into a type of quality of experience that is determined by sharing and communality. 'Now' is a 'qualitative term' that links the so-called caesuras of time (past, present, future) to form a remembrance that gives value to existence, namely the acknowledgement of being human via relationships. For this reason, hierarchy is also important, in which the elders call life's experience into remembrance, and in doing so, integrates them. Therefore, the elders deserve to be respected. ${ }^{34}$

\footnotetext{
32 "Preaching ... normally focuses on the present moment, on orality and aurality, memory, delivery, bodily enactment, and articulation of meaning in the 'now' before a congregation." Wilson (Childers and Schmit 2008:37).

33 See the discussion in Chapter 1.

34 Cf. the interesting discussion on 'the role of elders in African society' by Markwei (1979:15ff.).
} 
This recalling of life's experiences takes place by means of song, dance, stories, etc. - often with symbols taken from the immediate natural contexts, e.g. animal life. The stories, etc., then serve to conserve the values and traditions of the group and to transpose them from generation to generation. In this process, 'past', 'present', and 'future' fade away and are transformed into a type of trans-existence; it attains a mythical value of generative, continued existence. ${ }^{35}$ In this sense the importance of the spirits of the ancestors could also be understood as guardians over this trans-dimension. 'Now' is therefore not a fleeting second, but rather the rhythmic recalling and retelling of life within the mythical network of existence; it is rather a transtemporal, existential quality. ${ }^{36}$ 'Now' is about the (communal) 'quality of time, and, as I noted earlier, not the obliteration of time. ${ }^{37}$

As noted earlier: In Africa, time is tied to events. But that is probably not enough said. Events are also tied to time. Africans time the event; they however also invent (event!) the time. ${ }^{38}$ In my opinion, this reciprocity represents a remarkable correlation with so-called modern astrophysical notions of time. According to these notions, time is continuously being affected, moved, shaped, and warped by events in time.

If I may borrow a metaphor from nature to try and describe this dynamic reciprocity between event and time: time is like a wave in the ocean. ${ }^{39}$ It has a backside, a force behind its movement - call it the 'past' if you like. It has a crest, forever (!) moving forward, curving, gathering or losing momentum - let us call this movement the 'present'. But the wave is indeed also moving forward, poised to break - somewhere in its 'future'.

There is more than one wave, more than one moment of now, moving from the energies of the past towards the possibilities, the potentialities of a breaking future. This movement I would call 'now', being influenced by events, just as the movement of the wave is influenced by objects like the presence of sand banks or rocks, the depth of the ocean, the strength of the wind, or the proximity of the shore. ${ }^{40}$ In short: now is movement, not a monument being erected in the

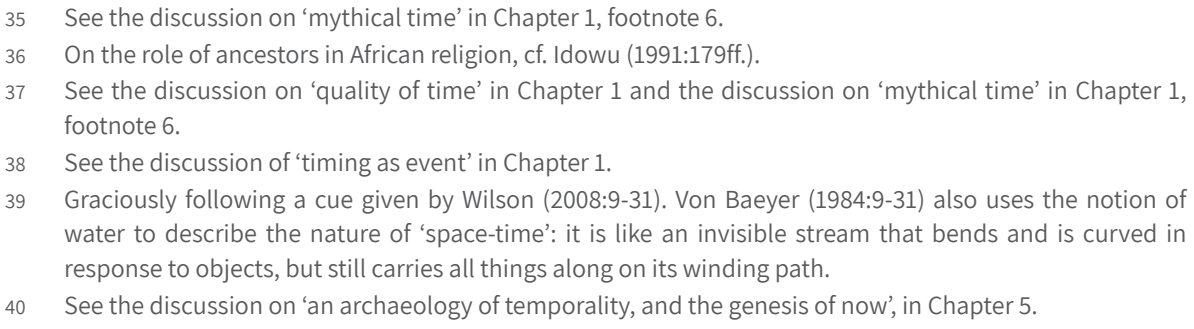


centre of the ocean, trying its best to resist the force of the waves, standing fixed and firm against the gale. Preaching is, in my opinion, the art of riding the waves of now; more than constructing a monument that must withstand the movement of these waves. (Preachers are surfers of the waves of God's grace of now; not site inspectors of steel constructions that must somehow preserve God's presence with us. $)^{41}$

'Secondly', this emphasis of the present, and the experience of events within the present, should not be equated to a narcissistic take on life, a type of stance that says, or perhaps sings with Freddie Mercury of the British rock group Queen - 'I want it all, and I want it now!'42 The 'now' of African rhythm does not know this kind of aggressive, temporal command and demand. Now is more than just a (mathematically measured) second, to be filled with as much pleasure as possible.

Speaking again in terms of preaching, now is rather (the experiencing of) an event, filled with the revelatory presence of God. This presence of God is indeed more than just a mathematically defined present; rather a moment of experience, of the event of exposure before God's face, of the experience of truth within the event of an encounter. In this sense, 'now' is not a temporal term, at least not primarily, but rather a qualitative, relational term. In preaching, the present is constituted (pre-sensed) by this Presence of God - an event that calls for hermeneutical observation and interpretation. This Presence of God grants the gift, the present of the Presence - as 'actual' time.

Actual time could also be called fulfilled time, or in biblical terms: Pleroma. ${ }^{43}$ To experience actual time is to experience the fullness, the Pleroma, of a given time in a given place. Pleroma, in the biblical sense of the word, indicates the fulfilment of God's intent in time and space, particularly in Christ. 'In Christ', all things, also cosmological, are unified and brought to its fruition. ${ }^{44}$ The notion of Pleroma has been described in many ways ${ }^{45}$ For me, Pleroma indicates God's intent being 'historically revealed within cosmological context as well as eschatologically concealed within signatory form. This means that the fullness

\footnotetext{
See the discussion on 'fixed God-images' in Chapter 3.

Queen (1989).

For a discussion of 'Pleroma', see Cilliers (2016a:44ff.) and the discussion in Chapter 5.

Cf. Ephesians 1:10.

In the classic works of the Dutch theologian, Van Ruler (1974:72-79), we find, for instance, a description of no less than ten characteristics of Pleroma (what he calls vervulling, fulfilment), namely its historical, concealed, signatory, pluralistic, paradoxical, sacramental and cultural, universal, cosmological, ordinary and irresistible dimensions.
} 
of experience of an encounter with God is a reality, i.e. historically real, but as such also influences things cosmological. Time and space, seen cosmologically, are affected by the reciprocal and historical encounters between God and human beings. But these experiences of fullness of encounters are also preliminary; i.e. Pleroma is preliminary, awaiting (further) fulfilment, without diluting the fulfilment of the historical dimension. Therefore, these experiences of Pleroma are often given to us in the form of signs, of fragments and outlines - which could easily be overlooked, and which calls for discernment. (In my opinion, preaching contributes towards this discernment [pre-sencing] of the 'now' of Pleroma.)

We are 'here', in the 'now' of this moment - and then we are gone. Indeed, as the Psalmist stated: our days are like grass; like the flowers of the field. ${ }^{46}$ Now here; tomorrow, no more. But what makes this 'here' worthwhile, giving weight and 'gravitas' to this fleeting presence? In the light of the African understanding of time, I would say: 'the Pleroma of encounters' - with God, but therefore also with my fellow humans, and may I add, with my fellow non-human creatures and creations (like the Karoo!). (Preaching discerns and celebrates this Pleroma of encounters.)

'Thirdly', African time also reminds us of 'potential' time, i.e. of the (inevitable) nearness of the future to the present. Again, in traditional theological terms, this could be called 'eschatology'. The latter is indeed not about a distant future, but rather a future that is always imminent, always before the door, which is always ready to be opened, if not already. Or, in the words of Mbiti:

Sisa has the sense of immediacy, nearness and 'newness'. It is the period of immediate concern for the people since that is 'where' or when they exist. To them, what will constitute future should be extremely brief. This is so because any meaningful event in the future must be so immediate and certain that people 'have almost experienced it'. ${ }^{47}$

It is quite remarkable that Mbiti's thoughts reveals some sort of 'discrepancy'48 in this regard: he sometimes describes the inevitable future as 'potential' time, but at the same time he also accepts the near future as 'actual' time (see again diagram above).$^{49}$ Personally, I would not call this a discrepancy. Would it be too daring to say that this 'overlap' of actual time and potential time, of the

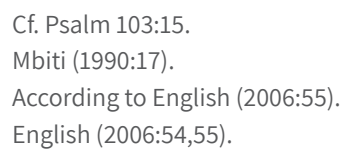


elusive and the inevitable in fact articulates a type of 'African eschatology'? That this overlap is indeed more about adventus, than about futurum?50

It is again remarkable to note how the early Christians had a 'bifurcated' sense of time and space, as for instance reflected in the Book of Revelation. ${ }^{51}$ The term 'bifurcated' indicates that reality (time and space) actually has two dimensions - that what is evident (for instance the powers of the 'empire'), but also the deeper, 'real' world of God. This bifurcated worldview has often been misunderstood in terms of an absolute separation between present and future - time is then divided into two consecutive stages: the (evil) present and the (distant) future. But, within the bifurcated view 'ordinary' and 'divine' life always 'coexist and places. Or, in terms of the terminology I used earlier: 'it is possible to experience a redeeming of time within (to be) redeemed time' - and preaching can play a role in this regard. ${ }^{52}$

This does not mean that these two worlds are condemned to eternal conflict; rather the conviction is that the world of God has 'already prevailed and continues to prevail' over all forms of worldly empire. The 'future' is not merely sequential to 'now'; rather they are 'co-present'. In present-orientated societies like those in Revelation (and may I add, in Africa) the 'future' is always understood as that which is 'enduring', i.e. already in the 'process of becoming' In this sense, eschatology is not about 'end-time events', but rather about 'real events', or in the terminology of Mbiti: it is about potential time overlapping with real time in such a way, that 'now' describes a new way of life. It indeed expresses 'the sense of immediacy, nearness and newness'; it is about a future that is 'so immediate and certain' that people 'have almost experienced it'.

Africans have often been accused of wasting time. In fact, they are not wasting time, but rather waiting on time; they are getting ready for time. ${ }^{53}$ This (inevitable) time to come could be the harvest, or the time for hunting, or the time for

50 See Cilliers (2009:26-35). I reiterate what I said earlier: In preaching, the future is often misunderstood as an experience of time exclusively related to a futurum, i.e. an attitude or mentality that somehow bypasses the present in its eagerness for the future. In the New Testament sense of the word, advent indicates a close connection between the saving presence of Christ 'who has already come' and the future. The hour that is coming, already is now (Cf. John 4:23; 5:25). Anticipation of the future - hope - is more about adventus (the continuous coming of the present One), than it is about strange, apocalyptical events in the distant future of the 'end times'. The notion of adventus transcends temporal categories; it is a term carrying a promise that is not qualified historically, but eschatologically. See the discussion in Chapter 3; and about 'the connections between anticipation and time' in Chapter 4.

51 See the enlightening work of Howard-Brook and Gwyther (1999:120-135). See the discussion in Chapter 4, concerning 'Allan Boesak's sermon'.

52 See the discussion in Chapter 1.

53 See Mbiti (1990:19). 
sowing. These seasons however indicate more than just annual events such as winter or spring; it rather points towards symbolic rhythms of life. It is the time when 'now' makes sense; it is a stance of expectation that waits for the (right) now; 'it is timing (of) the seasons of life'.

In the West, time (the present) is often viewed as a commodity that must be utilised; it becomes useful for pragmatic and technological reasons. Indeed: 'Time is money.' Therefore, time must not be 'wasted. ${ }^{54}$ In Africa, time must be 'created. For this you need the 'observation and interpretation', as well as the 'experience of events'; you need the individual, but you also need the 'community'. And, often, this cycle of seasons will be marked with religious rites and ceremonies - call it liturgy and preaching if you like - to be celebrated by the 'community'.

\section{The Kairos of the karos}

We see such celebrations already in the earliest rock art, such as that at Lonyana Rock in KwaZulu-Natal. ${ }^{55}$ This example depicts a kind of healing dance around a sick person wrapped in a blanket made of animal skin (karos).

The openness of the circle is striking, as if reflecting the inviting nature of the dance: people move towards the circle - and possibly out again? Are they out to find more people to join the dance? Do the animals - ancient representatives of the ecology - also want to be part of the circle?56 


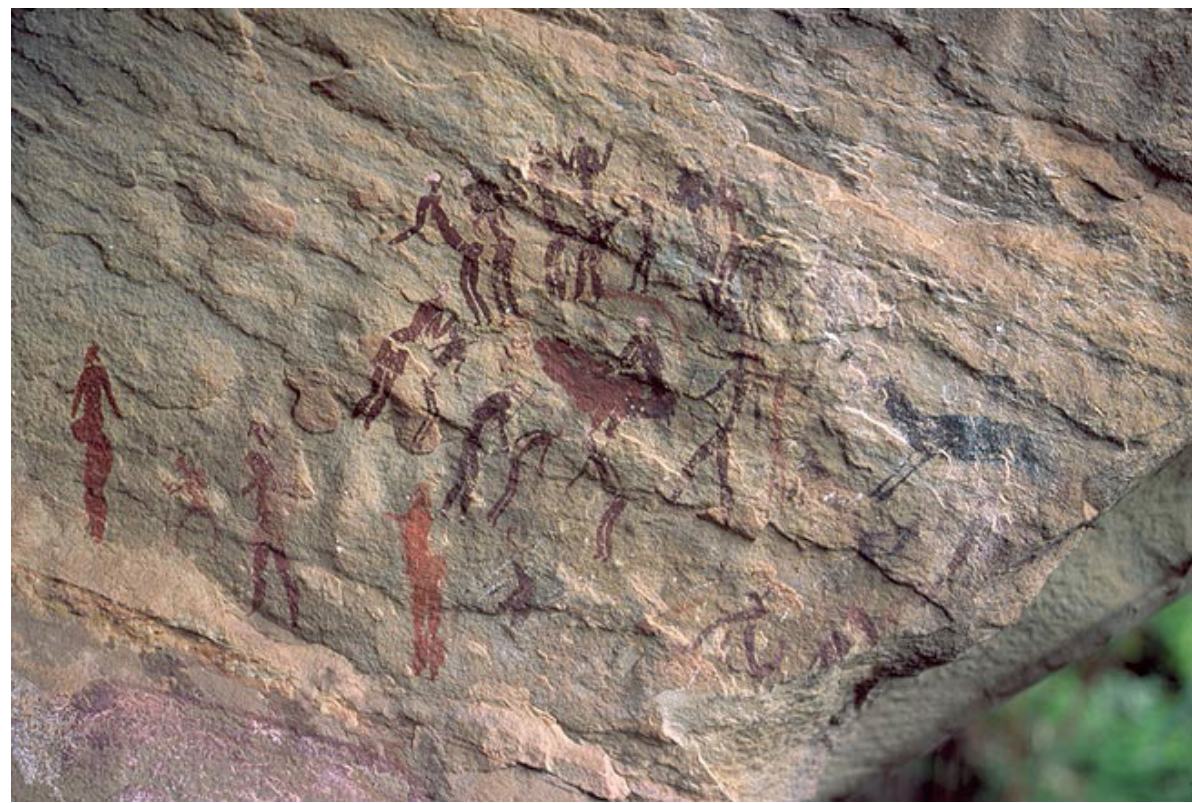

Figure 7.2 The San's trance ritual is depicted in this photo of Lonyana Rock in KwaZulu-Natal (Powel, 2016)

It is significant that the people forming the circle are dancing, i.e. 'celebrating' the seasons of life. Through and within this 'circle of celebration', the seemingly unstoppable onslaught, the seemingly inevitable progression of time from past, to present, to future, is transcended to form a new experience of the 'now' of life. It is not without reason that many scholars are of the opinion that most of these rock-art depictions were intended not only to give expression of everyday events, but to place them within a new, transcended framework. ${ }^{57}$ In effect they indicate that all the seasons of everyday life are in fact deeply spiritual, deeply religious, and to be celebrated in such a way that time is no longer viewed as an enemy, but as the space for experiencing the deepest meaning of life. ${ }^{58}$

Rock-art works like these are obviously thousands of years old. Yet, somehow, they offer a diachronic cross section of time, of 'now'. Although painted on rock, millennia ago, they offer an experience of 'now', now, i.e. today. They represent

57 Cf. Forssman and Gutteridge (2012:54ff.).

58 It is significant that the Shaman and the Rock-art artists were probably often the same person - the Shaman then depicting seemingly everyday scenes, but also from a trance-like, transcended perspective. Cf. the discussion in Woodhouse (2003:1ff.). 
a 'timeless' take on time; an eventful timing of event, within the celebratory circles of life. ${ }^{59}$

The depiction above indeed illustrates and celebrates the rhythms of (African) life. Like all good art works, it is open to interpretation. Is it, for instance, about a season of 'inevitable death', seeing that burials often took place by placing the body in a karos, as a type of natural 'coffin'? Or is it about a season of healing, i.e. of 'potential time'? Will the person in the centre die, or rise again? Will the karos become a death shroud, or a shield against the cold of coming winters? Or perhaps we have here a depiction of both, a season of death and birth, within the same circle? ${ }^{60}$

Let us interpret this (precolonial) depiction in terms of Mbiti's understanding of African time. Here we have 'actual' time (season of death, before going back into the past) but perhaps also 'potential time' - of healing, of new beginnings. Here we have the rhythms of African existence, of death and life, of life and death, of burial and resurrection - illustrated on a rock that predates time. In short: here we have a celebration of Kairos and karos. Here we have the Kairos of the karos - being danced out within the circle of 'now.61

Punctuality - Pünktlichkeit - is good, obviously; Kairos - the moment of God's inbreaking in time - is biblical, without a doubt. But punctuality may become commercialised obsessiveness; even Kairos may be usurped to serve imperial agendas. The tendency then is to equate certain historical events as biblical, as revelatory, as Kairos. Kairos could then become the Battle of Blood River, viewed from inside the enclave of encircled wagons. ${ }^{62}$ Kairos could read:

59 It is no wonder that this metaphor of life being danced out in the circle of now, found different expressions throughout history - one need only be reminded of the notion of Perichoresis, i.e. of God as Trinity dancing around in a circle. This reciprocal dance is described as an ecstatic sort of dance in which the persons of the Trinity literally 'stand outside themselves', while they evoke the life of the godly partners. It is a kind of movement, an interplay of self-offering which makes a reciprocal giving and taking of life possible. It represents the playful and inviting event of healing and homecoming, within the celebratory circle-dance of life. Pseudo-Cyril probably used the term perichoresis for the first time in a trinitarian context (sixth century), although Gregory and Maximus used the term earlier in a Christological sense to express the relation between human and godly in Jesus. Although the word perichoresis does not literally mean 'to dance around together' (it is derived from perichoreo, not perichoreuo), various theologians have pointed out the significant wordplay between the two Greek words. In time perichoresis did take on the dimension of the dance, and it does express something of the circular character of the eternal, godly life. See the discussion in Cilliers (2012:83ff.).

60 Could the idea of birth be strengthened by what some interpret as the figure of the woman with her child in the picture?

61 See the discussion on 'Kairos' in Chapter 2; for a further discussion of 'Kairos', see Cilliers (2016a:154ff.).

62 See Cilliers (2015:1-13). 
Gott mit Uns, propagated from Nazi podiums. Yes, Kairos could also be made to fit nicely into many South African political claims, old and new. ${ }^{63}$

Therefore, I would rather opt to re-qualify the notion of Kairos, placing emphasis on the temporal-relational dimension of 'communal sharing and caring. When time is experienced as sharing and caring, within the community, and if time is viewed as a gift from God, punctuality becomes infinity, and Kairos takes on the contours of a 'karos-community'. Kairos then is karos; karos is Kairos. This take on time then represents the presence, the Kairos of the caring Karos-God, not the imperial God conjured up by iron theologies, or kept intact through the construction of 'eternal' monuments. ${ }^{64}$

The depiction above speaks of such a 'Kairos of a karos-community'.

Indeed, here we have 'time' - in the fullest, and most fulfilling, sense of the word.

Here we have 'spiral-communal' time.

63 In the precise words of ex-President Jacob Zuma: "God expects [the ANC] to rule this country because we are the only organisation which was blessed by pastors when it was formed. It is even blessed in Heaven. That is why we will rule until Jesus comes back." And, said at the $105^{\text {th }}$ celebration of the ANC, held in Soweto on the $8^{\text {th }}$ of January, 2017: "As a nation we must never forget this day (of the celebration Jesus Christ), because it is like the day on which Jesus was born." In effect, Incarnation becomes Nation. See also Chapter 4, on Desmond Tutu. Cf. footnote 328 and Chapter 4, on Desmond Tutu.

64 For a description of 'Iron Theologies', see Cilliers and Campbell (2012:63ff.). 


\section{Sermon: A time to be BORN; A TIME TO DIE ...}

\section{God made everything to fit into a particular time ... ECCLESIASTES 3:2,11}

This verse, which speaks about a time to be born, and a time to die, could easily push you over the edge, into a dark pit of depression - in particular the second part. With the first part one could still heartily agree - the part that says that there is a time to be born. After all, this indicates the beginning of our existence, our coming into this world, the dawn of our consciousness of all and everything surrounding us. Who is, under normal circumstances, not happy when a baby sees the first light of day? Who does not shed a few tears of joy when hearing the first cry of a new-born child?

When our twins were born some years ago, I was privileged enough to be there. So many impressions indelibly engraved in my memory. Two of those keep on playing out in my mind's eye: the first cry of my daughter, and the way my son looked at me when the doctor placed both in my clumsy arms. I am not sure whether I imagined it, or whether it simply was my swollen fatherly pride, but for me the cry of my daughter sounded exactly like an excited jubilation at her entry into life, and my son's gaze as if he wanted to say: well, is this now how he looks; is this now my father? I experienced, like all parents, an indescribable joy at the birth of these new human beings; these new beginnings. After all, these are 'my' children! 'Unforgettable.'

Time stood still.

It is, however, concerning the 'second' part of the text that we have more troubling thoughts. A birth is beautiful, is good - but to die? Death? After all, this means the end of our earthly existence and consciousness. The end of the known and trusted. This means - for those who remain - that this voice becomes silent forever, that this smile will never be seen again, that the memory of this face will fade away. With this human being, we will never again sit around the table, celebrating life. The closure of an era. 'Grand Finale.' 
The end of time.

A time to die. Oh, could we not rather delete this part of the text ...?

And yet, we need not be pessimistic about this, or in fact 'any' part of the text. Both parts can fill us with a deep gratitude and comfort. Because, the author of this text continues: 'God made everything to fit into a particular time ..., verse 11. It is 'God' who determines our time to be born, and our time to die. As the psalmist concurs: "My times are in your hand." ${ }^{65}$ All of my life's moments are connected to the tick-tock of God's Clock ...

Because our dying moment is also in God's hand, death becomes a miracle, dare I say a graceful event - even if it saddens us, and even if it is our final enemy to overcome, 1 Corinthians 15:26. Through Christ this enemy is already a defeated enemy, rather a transition, a portal - to the fullness of eternal life. Therefore, we do lament, but we do not lament like people without hope, 1 Thessalonians 4:13.

Birth and death; death and birth - is this just the never-ending 'cycle of time' that we must accept, no matter what? Well, yes and no. Yes: we will all die, just as surely as we were born. No: we are not given over to this fate; on the contrary, there is a 'line of time', a telos to where we are headed, which gives meaning to our time in-between birth and death. We live, and die, in this hope.

After all, we do not die alone; we die with the knowledge that God is with us, even then. Helmut Thielicke writes:

The Lord does not safeguard us from suffering, but He does come to our aid in suffering. He does not declare us free from the burdens of life, but He carries them with us. He did not exile death, but allows this enemy, the last one on our life's journey, to threaten us. Even there He is with us - if we must leave this life, He does not leave us. He does not spare us the valley of the shadow of death, but goes with us through it, always the Shepherd that guides us with his staff, and keeps us from stumbling.

Yes, we have a Saviour that came in the fullness of time, a Saviour who not only experienced the first part of this verse Himself, but also the pain of the second part. A Saviour who had a time in which He 'had' to be born, and a time in which He 'had' to die. A Saviour who could therefore take our times, also our times to be born and to die, into his eternal hands, and who implanted in us

65 Psalm 31:16. 
an awareness of the worth of time, so that we could now make the best use of every opportunity in our lives. ${ }^{66}$

We know: our sands are running out. The hourglass never stands still. Soon we will be out of time; we will be above and beyond time, in eternity. Therefore, we are biding our time, making the best of it, while we can. And, if the time of our suffering feels too long for us, we know that a thousand years is for the Lord like one day, and one day like a thousand years, 2 Peter 3:8. Soon, we arrive at the second part of our verse: a time to die. Martin Luther once wrote:

When the hour comes for us to die, let us go and meet it as blessed people, because as soon as our eyes are closed and we are buried in the grave, we are resurrected. For a thousand years will be as if we were in the grave for just half an hour. When we sleep at night, we hear nothing, and we do not know what time or hour it is. If we experience this when we are sleeping, much more we will experience it in death. A thousand years will pass like a night's sleep, like a moment, like the blinking of an eye ...

Because God is not bound like us to the time, a thousand years must surely be as one day for Him. Therefore, the first human being, Adam, is as close to $\mathrm{Him}$ as the last person to be born before the youngest day, because God does not see the time in his length but in its breadth. If you look at a long tree lying in front of you, you can see both points at the same time. You cannot do this when looking down in its length (you then only see the round trunk in front of you, i.e. the present).

With our minds we cannot see time other than in its length, so we must start counting - from Adam one year after another to the last day. But for God everything is one. For Him, that which is long for us, is short; and that which is short, is long, For Him, there is no measure or number. So, people die, the body is buried and perish, it lays in the earth and knows nothing. But when the first human Adam will rise on the youngest day, he will think that he did not even lay there an hour. Then he would look around him and realise that so many people were born from him, and came after him, of which he knew nothing.

So, let us make good use of the time we have left. Let us, who are still living in-between the times of our birth and our death, us, for who only the first part 
of our text has become true, and are still waiting on the fulfilment of the second part, learn to use our days in such a way, that we become wise. ${ }^{67}$

'We have two lives and the second begins when you realise you only have one. ${ }^{68}$

Let us, above all, live in love, because:

Time is too slow for those that wait.

Too quick for those that fear.

Too long for those that mourn.

Too short for those that rejoice.

But for those who love,

Time is eternity. 


\section{Chapter 8 A Timely Conclusion}

In the preface to this book, I stated my conviction that preaching, albeit in different forms, will withstand the test of time. This concurs with my convictions regarding preaching when I first ventured into the academic field of homiletics. I expressed my belief then that preaching still has an important function to fulfil in the ministry in, and through, the congregation. ${ }^{1}$ I still hold this to be true, today.

The church would in fact suffer fundamentally if, in some or other way, preaching should be devalued or neglected and if, in our attempts to renew, we do not critically examine the art and act of preaching. Some readers might have found some of the analyses in this book too critical. These analyses were not done lightly, and are intended to open, or re-open, the discussion about the important event of preaching. If these analyses contribute towards a deeper reflection on preaching, it will have fulfilled its intention. Fools rush in, where angels fear to tread ...

Preaching does have a role to play, but must not be overestimated, or underestimated. A congregation is more than a worship service, and a worship service is more than a sermon. Sermons however do represent 'moments in time', which are links between the biblical testimony of what God has done and the promises of God's future deeds - in such a way that a space and time for grace is opened up, within which the present is experienced as a Presence.

Preaching is essential for the welfare of the church. Yet, it seems as though preaching, indeed, is degenerating. This is a sad reality, but I would still describe preaching as the heart of the church (cor ecclesiae). Preaching is a display window, whether we are aware of it. It remains a kind of barometer of the church that reflects the church's state of health. One could justifiably say 'as the preaching, so the church; as the church, so the preaching.'

What follows, represents a re-visitation of some of the convictions I had when first starting out as a homiletician. See Cilliers (2004/2013:18-21). 
In concrete preaching, many aspects culminate: the preacher's dogmatic convictions, ethics, scriptural view, historical awareness, pastoral and exegetical skills, hermeneutical capacity, psychological, emotional and spiritual maturity, and much more. Concrete sermons paint pictures of theological and ecclesial activities - colourful and exciting, or drab and boring. They bear witness to either regeneration, or degeneration. (After writing this book, I would add that preaching reveals, above all else, the preacher's wisdom for timing grace - or lack thereof.)

Even in the face of many, valid critical voices, I believe that preaching still is one of the most hopeful acts in which we can participate. In fact, to preach is to hope. (Preaching is a concentrated form of Christian hope.) It often takes place although there is apparently no, or few, results, often against the odds of seemingly overwhelming powers and factors, often as the persistence of enduring hope. So, why preach? Why hope?

Firstly, because preaching can change people. (The Word of God comes to transform us - it will not return to God empty but will accomplish what God desires and achieve the purpose for which God sent it.) This transformation through preaching can already be seen in Scripture, although Scripture does not refer to preaching in the traditional, church-historical sense of the word. 'Preaching' in biblical times took on various forms, for example as shorter acts of witnessing, longer expositions before larger audiences, or basic apostolic confessions concerning the Lordship of Jesus of Nazareth. Furthermore, the basis of these forms of preaching was not the complete canon as we know it now, but mainly the Old Testament, oral witnesses about Jesus Christ's life, death and resurrection and, possibly, fragments of certain New Testament writings. Throughout church history, many other sermonic forms were used, and, without a doubt, many more will make an appearance.

Whatever the case may be, preaching has served the continuation of the Gospel by transforming people. When Peter preached on the first day of Pentecost, the people's hearts were struck and they asked: "What should we do?"2 When Philip proclaimed the Gospel in Samaria, a whole city was in turmoil, resulting in great joy. ${ }^{3}$ When Paul preached about Christ in Philippi, the Lord opened the heart of a woman named Lydia. ${ }^{4}$ And so we could continue. This also happened for all of church history - moments of divine and human timing between 
specific sermons and specific situations. Moments of timed and timely grace, through which God transformed people.

Secondly, because preaching is not an empty word, but a word in which God is present as Presence in time and speaks. When preaching, our most profound hope resides in this fact of God's present Presence. Timing hinges on, and trusts in, this Presence of God in the present. 'Timing as trusting' rests on the conviction that, in some or other (often inexplicable) way, the present God encounters people through preaching. When Peter speaks about the gifts within the congregation, amongst others also the gift of preaching, he elaborates: 'Whoever preaches must preach God's messages. His or her words should be like words of God. ${ }^{5}$

Like words of God? Really? Some people would probably call this an overestimation of preaching. I (still) do believe in this possibility, this promise, not in a mechanical or automatic sense, but as the result of timing grace, in the multi-layered sense that we have been using this expression throughout this book. Timing grace as a confession, a longing, and a prayer that our words indeed become God's words in our sermons - as a simultaneity, a synchronicity of interruptive grace. (Prayer in fact forms the underlying structure of all timing of grace in preaching.)

Preaching is about the timing of grace, i.e. pre-sencing of the Presence of God in the present. Perhaps someone could ask, here at the end of this book: but what constitutes God's Presence in the present? How could it be described, and what form or forms does it take? I have been hesitant, and still is, to answer these questions, rather stressing the fact that this Presence is elusive and fluid, not to be fixated or patented. ${ }^{6}$ I postulated that preaching in fact constructs God-images, only to simultaneously deconstruct them. ${ }^{7}$ God is (always) more than our (homiletical) grip and grasp on God.

We could - still hesitatingly say - that God is present in the existence of the body of the Church (Bonhoeffer), or that God is present in the bodies of the poor and the marginalised, even as a disabled One, sitting in a wheelchair (Eiesland), or that God is present in the masquerade of all of creation (Luther). ${ }^{8}$ This presence of God often goes by unnoticed - as exemplified in the life-size

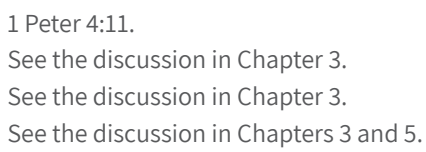


sculpture by Canadian artist, Timothy Schmalz. A first look reveals nothing, except the homelessness of humanity. Or does it?

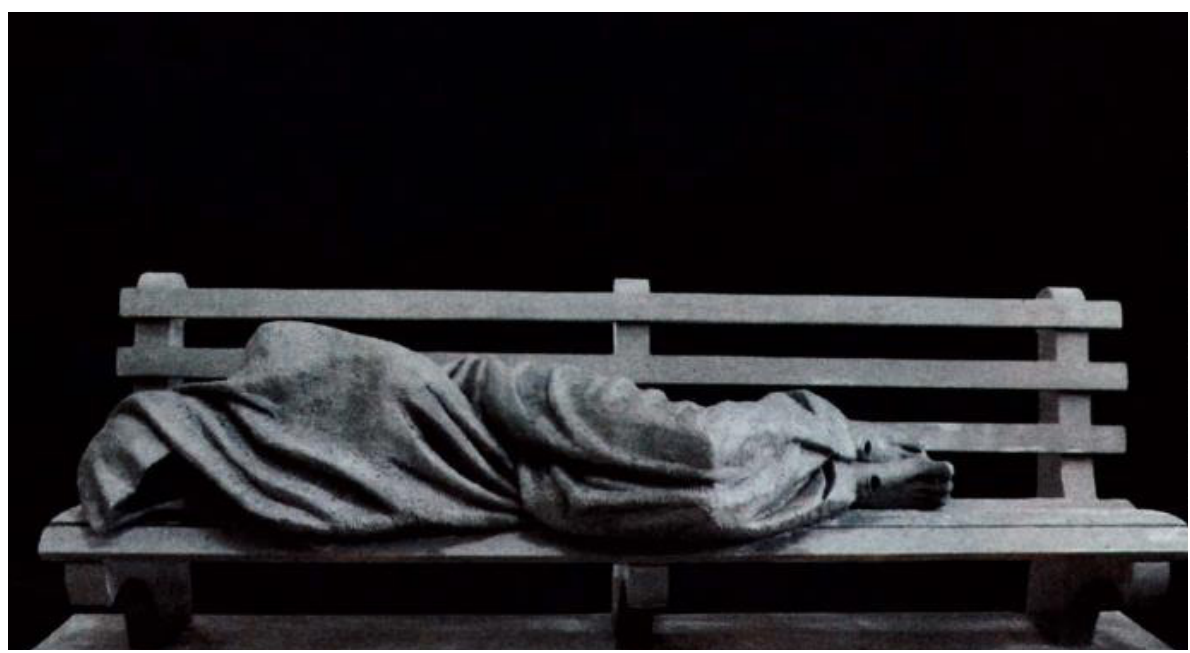

Figure 8.1 Timothy Schmalz's Homeless Jesus (2012) has a realistic bronze finish and is mounted on a solid matt black base

Look again, at the homeless person's feet. Perhaps we experience a shock of recognition. Is it Jesus lying on a bench in a park? Homeless?

But even as we say this, we (should) know that all these possible forms or modes of God's Presence are not meant to be fixated, or to become another handle that we create to move God around according to our agendas and ideologies. God's Presence remains elusive, but nevertheless, real. Preaching as the pre-sencing of God's Presence in the present, always calls for wisdom and discernment, and should not become another homiletical tool or handle to mishandle or style or patent God. Timing as pre-sencing, improvising and synchronizing - and all the other concepts used in this book - are also not meant to be recipes that would guarantee God's Presence in the present.

On the contrary, the way in which we preach, does not automatically or magically guarantee God's presence. God can be 'absent' from the pews and be silent during the sermon. ${ }^{9}$ God can be deaf to the congregants' prayers and the choral music. God 'is' present, but this presence must be discovered and uncovered - time and again pre-sensed as (uncontrollable) grace. 
This cannot be emphasised enough: we cannot capture God with or within our sermons. The praesentia realis of God is an answer to our faith, but never in a causal sense. On the contrary, the relationship between God's presence and our faith (and preaching) could as well be reversed. Preaching can therefore never be a tool or recipe to manipulate God's presence, and yet - and this can also not be emphasised enough causal preaching 'can' play a part in our experience of the mystery of this presence. Especially this - that preaching can become an event (time, space) of grace, through grace causal remains a tremendous and fascinating mystery. ${ }^{10}$

In the 'third place', we preach, and we hope because preachers need not invent grace. It has already been given to us in the fullness of time, as Kairos and Pleroma. ${ }^{11}$ We receive this grace, through the Christ-event, and do not invent it. Paul could state without hesitation that it was his intention to speak to the Corinthians about 'nothing but Jesus Christ and especially his death on the cross. ${ }^{12}$ Indeed, 'Christ is our grace, even as Christ is our hope. ${ }^{13}$ That is why we preach.

I believe that preaching it is one of the most crucial events that can take place 'in times like these.' Indeed:

Preaching is the highest and the greatest and the most glorious calling to which anyone can ever be called ... the most urgent need in the Christian Church is true preaching; and as it is the greatest and the most urgent need in the Church, it is obviously the greatest need of the world also. ${ }^{14}$

10 This is as far as I would be prepared to go when describing the content of the present that is filled with the Presence of God - it remains a tremendous, fascinating mystery. According to the classic distinctions made by Otto (1917:12-46), the numinous mystery of the Holy God can be experienced in two ways: as attraction (fascinosum) or as object of fear (tremendum). In our approach to God, we normally undergo both these experiences - hence God could rightly be called a mysterium tremendum et fascinans. The components (or moments) of the experience of the numinous as tremendum include, according to Otto (1917:12-46) the following - and these could rightly also be called components of the homiletical act of pre-sencing the presence of God in the present - awe; acknowledging God's majesty; vitalization; and experiencing the mystery of a totally different and completely strange God. Respectively: 'des Schauervollen', 'des Übermächtigen', 'des Energischen', 'Das Ganz Andere'. But the presence of God does not only entail an experience of tremendum, it also attracts us towards God (fascinans). Otto describes the latter as the experience of overflowing affection. We are attracted to God because God approaches us - through grace. See Cilliers (2009:31-44).

11 Cf. Colossians 4:3.

121 Corinthians 2:2.

131 Timothy $1: 1$.

14 Lloyd-Jones (1976:9). 
We preachers, together with all the church, have been entrusted with words that the world needs and, consciously or subconsciously, yearns for - today, now. Sometimes, people may laugh at us, ridicule us, reject us, but we have received words that make all the difference. With this conviction, I have written this book.

Now, it is time to stop.

In spe ... 


\section{BIBLIOGRAPHY}

Abdalla, M. 2014. Simpsons Explain Fracking (video online). Available at: https://www.youtube.com/watch?v=MEtaX8f1pdo

Alexandrian, S. 1970. Surrealist Art. London: Thames \& Hudson.

Allen, J. 2006. Rabble-Rouser for Peace. The authorised biography of Desmond Tutu. London: The Free Press.

Alves, R. 1972. Tomorrow's Child. Imagination, Creativity, and the Rebirth of Culture. London: SCM Press.

Antonova, C. 2010. Space, Time, and Presence in the Icon. London: Routledge.

Appadurai, A. 1996. Modernity at Large: Cultural Dimensions of Globalization. 2nd Edition. Public Worlds 1. Minneapolis: University of Minnesota Press.

Arbuckle, G.A. 1991. Grieving for change. A spirituality for refounding communities. London: Cassel Publishers Limited.

Babalola, S.F. and Alokan, O.A. 2013. African Concept of Time, a Socio-Cultural Reality in the Process of Change (pdf). Journal of Education and Practice, 4(7):143-147. Available at: https://bit.ly/2YnOMbx

Barnard, M. and Vos, C.J.A. 2001. 'n Besinning oor die Liturgie. Teorievorming, Ondersoek en Praktykvorming. Praktiese Teologie in Suid-Afrika, 16(2):17-32.

Barnard, M. 2013. De missionaire tragikomedie. Woord en dienst, 62(9):34.

Barnard, M., Cilliers, J.H. and Wepener, C. 2014. Worship in the Network Culture. Liturgical-Ritual Studies - Fields and Methods, Concepts and Metaphors. Leuven: Peeters Press.

Bartels, K.H. 1979. Remember, Remembrance. In Brown, C. (ed). The New International Dictionary of New Testament Theology. 3rd Edition. Exeter: The Paternoster Press. 230-247.

Barth, K. 1958. Church Dogmatics IV, 2. In Bromiley, G.W. and Torrance, T.F. (eds). Translated by G. Bromiley. Edinburgh: T\&T Clark. 22.

Barth, K. 1993. The Theology of John Calvin. Grand Rapids, MI: Wm. B. Eerdmans Publishing Company.

Barthes, R. 1964. Mythen des Alltags. Frankfurt: Suhrkamp Verlag.

Battle, M. 1997. Reconciliation: The Ubuntu Theology of Desmond Tutu. Cleveland: The Pilgrim Press.

BBC, 2015. Steve Reich's eureka moment with 'It's Gonna Rain' Masters of Minimalism: Steve Reich - BBC Arts (video online). Available at: https://www.youtube.com/watch?v=uUTRS0iW7oE 
Benjamin, W., Bullock, M., Jennings, M., Eiland, H., Smith, G., Jephcott, E. and Livingstone, R. 2003. Walter Benjamin Selected Writings, 1-4. Cambridge, Mass: Belknap Press of Harvard University Press.

Berkhof, H. 1973. Christelijk Geloof. Een inleiding tot de geloofsleer. 3rd Edition. Nijkerk: Callenbach.

Bettmann 1984. Children playing with dolls on trash heap. Getty Images (online). Available at: https://bit.ly/2Loi4Dq

Bild-Kunst, V.G. 2006. Joseph Beuys's Crucifixion (Sculpture made in 1962-1963 with wood, bottles, electrical cable, wire, paper, oil, plaster, nails, needles) (image online). Available at: https://bit.ly/2GnLZIu

Bloch, E. 1966. The Principle of Hope. Chicago: MIT Press.

Blumhardt, J.C. 1991. Schriftauslegung. Ausgewählte Schriften, 1. Giessen: Brunnen Verlag.

Boesak, A. 1979. The Finger of God. Sermons on Faith and Responsibility. Translated from Afrikaans by P. Randall. Johannesburg: Ravan Press.

Bohren, R. 1962. Mission und Gemeinde. Theologische Existenz heute. Neue Folge Nr. 12. München: Kaiser Verlag.

Bohren, R. 1980. Predigtlehre. München: Kaiser Verlag.

Bohren, R. and Jörns, K.P. 1989. Die Predigtanalyse als Weg zur Predigt. Tübingen: Francke Verlag.

Bonhoeffer, D. 1955. Ethics. London: SCM Press.

Bonhoeffer, D. 1998. Sanctorum Communio. A Theological study of the Sociology of the Church. Translated from German by R. Kraus and N. Lukens. Minneapolis: Fortress Press.

Booth, N.S. Jr 1993. Time and African beliefs revisited. In Olupona, J.K. and Nyang, S.S. (eds ). Religious Plurality in Africa, Essays in Honour of John S. Mbiti. Berlin and New York: Mouton De Gruyter.

Bosch, D. 1995. Transforming Mission: Paradigm Shifts in the Theology of Mission. Maryknoll, N.Y.: Orbis Books.

Boshego, L.P. and Lloyd, D.W. 2009. G.H. Franz Modjadji: archetypes of time and the transcendence of history. Literator 2009, 30(3):157-178. https://doi.org/10.4102/lit.v30i3.92

Bosman, H. 2001. All Past and Present but little Future? African and Old Testament Concepts of Time and History. In Getui, M., Holter K. and Zinkuratire, V. (eds). Interpreting the Old Testament in Africa. New York: Peter Lang. 101-112.

Botha, J. and Forster, D.A. 2017. Justice and the Missional Framework Document of the Dutch Reformed Church. Verbum et Ecclesia, 38 (1). https://doi.org/10.4102/ve.v38i1.1665

Brooks, K. 2014. 10 Famous Art Works That Celebrate Father Time. Huffington Post (online). Available at: https://www.huffpost.com/entry/art-about-time_n_6392666 
Brueggemann, W. 1978. Prophetic Imagination. Philadelphia: Fortress Press.

Brueggemann, W. 1989. And finally comes the poet. Daring speech for proclamation. Minneapolis: Fortress Press.

Brueggemann, W. 1993. Texts under negotiation. The Bible and postmodern imagination. Minneapolis: Fortress Press.

Brueggemann, W. 2003. Ancient Utterance and Contemporary Hearing. In Resener, A. Jr (ed). Just Preaching. Prophetic Voices for Economic Justice. St. Louis, Missouri: Chalice Press.

Burnet, J. 1951. Greek Philosophy. London: Macmillan and Co. Ltd.

Butler, A., Van Cleave, C. and Stirling, S. 1996. The Art Book. London: Phaidon.

Cahill, L.S. 1994. From Christ to the World. Introductory Readings in Christian Ethics. Grand Rapids: Wm. B. Eerdmans Publishing Company.

Calvin, J., McNeill, J. and Battles, F. 1960. Institutes of the Christian Religion. Translated by F.L. Battles. Philadelphia, PA: Westminster John Knox Press, 1(17):13, 1(11):3, 2(11):13, 2(16):2).

Cambridge University Press, 2019. Meaning of hygge in English. Cambridge Dictionary (online). Available at: https://bit.ly/2xzxahl [Accessed 6 November 2018].

Campbell, C. and Cilliers, J. 2012. Preaching Fools. The Gospel as a Rhetoric of Folly. Waco, Texas: Baylor University Press.

Campbell, C. 2015. Vom Jazz Lernen. Ein US-amerikanischen Votum jenseits von Tradition und Innovation. In Meyer, P. and Oxen, K. (eds). Predigen lehren. Methoden für die homiletische Aus-und Weiterbildung. Leipzig: Evangelische Verlagsanstalt.

Caputo, J.D. 2006. The Weakness of God: A Theology of the Event. Bloomington and Indianapolis, IN: Indiana University Press.

Chauvet, L. 1995. Symbol and Sacrament: A Sacramental Reinterpretation of Christian Existence. Translated by P. Madigan and M. Beaumont. Collegeville, Minnesota: The Liturgical Press.

Cilliers, J. and Nell, I. 2011. Within the enclave - Profiling South African social and religious developments since 1994. Verbum et Ecclesia, 32(1):1-7. https://doi.org/10.4102/ve.v32i1.552

Cilliers, J. 1996. Die Uitwissing van God op die kansel. Ontstellende bevindinge oor Suid-Afrikaanse prediking. Cape Town: Lux Verbi.

Cilliers, J. 2004. The Living Voice of the Gospel. Revisiting the Basic Principles of Preaching. Stellenbosch: AFRICAN SUN MeDIA. https://doi.org/10.18820/9781919980287

Cilliers, J. 2011a. Fides Quaerens Pulchrum: Practical Theological Perspectives on the Desire for Beauty. Scriptura: International Journal for Bible, Religion and Theology in Southern Africa, 108(3):257-266. https://doi.org/10.7833/108-0-1 
Cilliers, J. 2015. God in Granite? Aesthetic-Theological Perspectives on the Monumentalisation of Religion. Scriptura: International Journal for Bible, Religion and Theology in Southern Africa, 114(1):1-13. https://doi.org/10.7833/108-0-1

Cilliers, J. 2009. Time out. Perspectives on liturgical temporality. NGTT: Dutch Reformed Theological Journal, 50(1,2):26-35.

Cilliers, J. 2011. Das Klingen des Lebens: Liedübertragungen als Transfer religiöser Kulturpraxis: Das Kirchenlied zwischen Sprache, Musik und Religion. Veranstaltung zu Ehren von Prof. Dr Jürgen Henkys anlässlich seines 80. Geburtstages. Berliner Theologische Zeitschrift, 28(2):279-299.

Cilliers, J. 2010. The unveiling of life: Liturgy and the lure of kitsch. HTS Theological Studies, 66(2):1-5. https://doi.org/10.4102/hts.v66i2.815

Cilliers, J. 2017. Between dwellings and doors: Spatial perspectives on preaching. HTS Theological Studies, 73(2):6. https://doi.org/10.4102/hts.v73i2.3858

Cilliers, J. 2018. Poverty and Privilege. Re-hearing sermons of Beyers Naudé on Religion and Justice. Stellenbosch Theological Journal, 4(2). http://dx.doi.org/10.17570/ngtt.2009.v50n1.a03

Cilliers, J. 1982. Soos Woorde van God: Ontwerp van ' $n$ Preekanalitiese Model (unpublished DTh thesis). Stellenbosch: Stellenbosch University.

Cilliers, J. 2000. The Grace of Obedience. How evangelical are the ethical sermons we hear in South Africa? Cape Town: Lux Verbi BM.

Cilliers, J. 2006. God for Us? An analysis and assessment of Dutch Reformed preaching during the Apartheid years. Stellenbosch: AFRICAN SUN MeDIA. https://doi.org/10.18820/9781920109134

Cilliers, J. 2016a. A Space for Grace. Towards an Aesthetics of Preaching. Stellenbosch: AFRICAN SUN MeDIA.

Cilliers, J. 2014b. A Royal waste of Time? Perspectives on Liturgy as Space against Waste. Scriptura: International Journal for Bible, Religion and Theology in Southern Africa. 113. https://doi.org/10.7833/113-0-724

Cilliers, J. 2011. Between Remembrance and Restitution: a practical theological investigation into the impact of the Truth and Reconciliation Commission (TRC) within the South African context of religion, diversity, and conflict. Religion, Diversity and Conflict. New Jersey, USA: Transaction Publishers.

Cilliers, J. 2015. Between separation and celebration: Perspectives on the ethical-political preaching of Desmond Tutu. Stellenbosch Theological Journal, 1(1):41-56. http://dx.doi.org/10.17570/stj.2015.v1n1.a2

Cilliers, J. 2012a. Disabling God in an able world? Analysis of a South African sermon. NGTT: Dutch Reformed Theological Journal, 53(1):1-12. https://doi.org/10.5952/53-1-110

Cilliers, J. 2016b. Just Preaching ... in times of transition. South African Perspectives. International Journal of Homiletics, 1(1):21-33.

Cilliers, J. 2014a. Predigt als politisches und eschatologisches Ereignis. Wahrnehmungen aus Südafrika. In Deeg, A. (ed). Erlebnis Predigt. 
Eine Veröffentlichung des Ateliers Sprache e. V. Braunschweig.

Leipzig: Evangelische Verlagsanstalt. 123-140.

Cilliers, J. 2013. Prophetic preaching in South Africa: exploring some spaces of tension. NGTT: Dutch Reformed Theological Journal, 54(1,2):1-15. https://doi.org/10.5952/54-1-2-299

Cilliers, J. 2008. Silence is golden: liturgy beyond the edge of language. Praktiese Teologie in Suid-Afrika, 23(1):19-35. https://doi.org/10.4102/ids.v43i1.213.

Cilliers, J. 2009. Mysterium tremendum et fascinans. Liturgical perspectives on the Approach to God. Die Skriflig. 43(1):31-44. https://doi.org/10.4102/ids.v43i1.213

Cilliers, J. 2014. Sounding Salvation: Theological Perspectives on music as articulation of life. The Journal for Transdisciplinary Research in Southern Africa, 10(2):36-48. https://doi.org/10.4102/td.v10i2.97

Cilliers, J. 2013. The Living Voice of the Gospel? Re-hearing a Prophetic Voice from Apartheid South Africa. In Hermelink, J. and Deeg, A. (eds). Viva Vox Evangelii - Reforming Preaching. Societas Homiletica 9. Leipzig: Evangelische Verlagsanstalt. 161-180. http://dx.doi.org/10.17570/stj.2015.v1n1.a9

Cilliers, J. 1994. God vir ons. 'n Analise en beoordeling van Nederduitse Gereformeerde volksprediking (1960-1980). B-reeks van Woord teen die lig. Cape Town: Lux-Verbi. 2.

Cilliers, J. 2010. The absence of presence: Homiletical reflections on Martin Luther's notion of the masks of God (larvae dei). Acta Theologica, 30(2):36-49. https://doi.org/10.4314/actat.v30i2.67262

Cilliers, J. 2012b. Dancing with Deity. Re-imagining the beauty of worship. Wellington: Bible Media.

Clayton, P. and Peacocke, A. 2004. In Whom We Live and Move and Have Our Being: Panentheistic Reflections on God's Presence in a Scientific World. Grand Rapids, MI: Wm. B. Eerdmans Publishing Company.

Coetzee, M. Die 'Kritiese stem' teen apartheidsteologie in die Ned. Geref. Kerk (1905-1974): 'n Analise van die bydraes van Ben Marais en Beyers Naudé (unpublished PhD, in press 2010). Cape Town: University of Western Cape.

Coetzee, M. 2013. Eertydse Nederduitse Gereformeerde teologiese denkstrome ten grondslag van Beyers Naudé se kritiek op apartheid. NGTT: Dutch Reformed Theological Journal, 54(3-4):1-15. http://dx.doi.org/10.5952/54-3-4-372

Coetzee, M. Hansen, L. and Vosloo, R.R. (eds). 2013. Vreesloos Gehoorsaam. 'n Keur uit Beyers Naudé se preke 1939-1997. Beyers Naudé Centre Series on Public Theology. Stellenbosch: AFRICAN SUN MeDIA.

Coetzee, M., Muller, R. and Hansen, L. (eds). 2015. Cultivating Seeds of Hope. Conversations on the Life of Beyers Naudé. Stellenbosch: AFRICAN SUN MeDIA. https://doi.org/10.18820/9781920689711 
Cohen, L. 1992. The Future. Columbia Records (Spotify web player). Available at: https://open.spotify.com/album/7E4FRoU4Pk0WuO1SQMV1Bo

Cohen, L. 2016. You want it darker. Columbia Records (Spotify web player). Available at: https://open.spotify.com/album/3jeTB3j3QmUs8SPIVleHtU

Conradie, E. 2010. Creation and salvation in the Wake of Calvin: Some reflections from within the South African context. NGTT: Dutch Reformed Theological Journal, 51:357-369.

Conradie, E. and Ayre, C.W. (eds). 2016. The Church in God's Household. Protestant Perspectives on Ecclesiology and Ecology. Pietermaritzburg: Cluster Publications.

Craddock, F. 1985. Preaching. Nashville, TN: Abingdon Press.

Dalí, S. 1931. Melting clock. Dalí Museums (electronic print). Available at: https://shop.salvador-dali.org/en/icons-dali/melting-clock.html [Accessed 3 October 2018].

Dalí, S. 1931. The Persistence of Memory. Museum of Modern Art (MoMA), New York (online). Available at: https://www.moma.org/collection/works/79018

Dawn, M. 1999. A Royal 'Waste' of Time. The splendor of worshipping God and being Church for the world. Grand Rapids, Michigan/ Cambridge, UK: WmB. Eerdmans Publishing Company.

De Chardin, T. 1977. Christianity and Evolution. London: Collins.

De Gruchy, J. 2002. Reconciliation Restoring Justice. Minneapolis: Fortress Press.

Debray, R. 2000. Introduction à la médiologie.

Paris: Presses Universitaires de France.

De Kock, C. 2014. Kunsresensie: Fear \& Loss - Industrial Karoo. (online). Available at: https://www.litnet.co.za/kunsresensie-fear-loss-industrial-karoo/

Dewey, M. 2013. Don't Frack with Our Karoo. Malcolm Dewey Fine Art (online). Available at: https://bit.ly/2XwQXZk [Accessed 21 May 2017].

Dickens, C. 1859. A Tale of Two Cities. London: Chapman \& Hall. Book 1, Chapter 1.

Die Kerkbode, 29 August 1973.

Durand, J.J.F. 1976. Die Lewende God. Pretoria: NG Kerkboekhandel.

Dutch Reformed Church, 2014. Document Folder. Supporting Documents: Dutch Reformed Church. Re-enactment of the Truth and Reconciliation Commission's Faith Hearing with a specific focus on reconciliation in a post-TRC South Africa. 8-9 October 2014, Stellenbosch.

Eco, U. 1979. The Role of the Reader: Explorations in the Semiotics of Texts. Bloomington: Indiana University Press.

Eco, U. 2004. On Beauty. London: Secker \& Warburg.

Eiesland, N.L. 1994. The Disabled God. Towards a Liberatory Theology of Disability. Nashville: Abingdon Press. 
Eliade, M. 1971. The Myth of the Eternal Return: Cosmos and History. Princeton: Princeton University Press.

Eliot, T.S. 1962. The complete poems and plays, 1909-1950.

New York: Harcourt, Brace \& World.

Elliot, C. 1987. Comfortable Compassion? Poverty, Power and the Church. London: Hodder and Stoughton.

English, P. 2006. Kalumba, Mbiti, and a Traditional African Concept of Time. Philosophia Africana, 9(1):48-59. https://doi.org/10.5840/philafricana20069111

EuroArtsChannel, 2018. Steve Reich - Phase to Face | The Father of Minimal Music with John Cage \& Philip Glass (video online) Available at: https://bit.ly/2ZRCsAK

Evdokimov, P. 1996. The Art of the Icon: A Theology of Beauty. New York: Oakwood Publications.

Fahmi, W.S. 2005. The Impact of Privatization of Solid Waste Management on the Zabbaleen Garbage Collectors of Cairo. Environment E Urbanization, 17(2). https://doi.org/10.1177/095624780501700212

Fahmi, W. and Sutton, K. 2006. Cairo's Zabbaleen Garbage Recyclers: Multinationals' Takeover and State Relocation Plans. Habitat International, 30(4): 809-837. https://doi.org/10.1016/j.habitatint.2005.09.006

Finca, B. 2007. Restitution Imperative in a Fragile Democracy. Paper presented at the annual meeting of the Foundation for Church-led Restitution. Cape Town.

Forssman, T. and Gutteridge, L. 2012. Bushman Rock Art. An Interpretative Guide. Pinetown: Southbound, South Publishers.

Fotoeins Fotografie, 2016. Berlin Grunewald: no train will ever leave track 17: Memorial by Karol Broniatowski, 18 October 1991 (online photo). Available at: https://bit.ly/2RFctcY

Friedland, R. and Hecht, R.D. 2006. The powers of place. In Stier, O. and Landres, J.S. (eds). Religion, Violence, Memory, and Place. Bloomington and Indianapolis: Indiana University Press. 17-35.

Ganson, A. 2009. Machines and the Breath of Time. The Long Now Foundation (video online). Available at: https://bit.ly/2FPVZtZ

Ganzevoort, R.R. and Roeland, J.H. 2014. Lived religion: The praxis of practical theology. International Journal of Practical Theology, 18(1):91-101. https://doi.org/10.1515/ijpt-2014-0007

Gell, A. 1992. The Anthropology of time. Oxford: Berg Publishers.

Giliomee, H. and Mbenga, B. 2007. New History of South Africa. Cape Town: Tafelberg Publishers.

Goetzmann, J. 1976. Mind. In Brown, C. (ed). The New International Dictionary of New Testament Theology, 2. Exeter: The Paternoster Press. 616-620.

Good News Bible (n.d.). 
Goshu, W. 1981. Commemorating the dead in painting: Resurrection (online print). Available at: http://www.ethiopianart.org/articles/articles.php?id=19

Gräb, W. 2013. Predigtlehre. Über religiöse Rede.

Göttingen: Vandenhoeck and Ruprecht. https://doi.org/10.13109/9783666624278

Graves, M. 1997. The Sermon as Symphony: Preaching the Literary Forms of the New Testament. Valley Forge, PA: Judson Press.

Guder, D.L. and Hunsberger, G.R. 1998. Missional Church: A Vision for the Sending of the Church in North America. Grand Rapids: Wm. B. Eerdmans Publishing Company.

Guillet De Monthoux. P. 2004. The art firm: aesthetic management and metaphysical marketing. Chicago: Stanford University Press.

Gustafson, James. 1988. Varieties of moral discourse: prophetic, narrative, ethical and policy. Michigan, Grand Rapids: Wm. B. Eerdmans Publishing Company.

Gyekye, K. 1987. An Essay on African Philosophical Thought:

The Akan Conceptual Scheme. Philadelphia: Temple University Press.

Hacker, M. and Goodman, E. Kindertransport: European History. Encyclopaedia Britannica. Available at: https://bit.ly/2NlHaVT

Hansen, G.W. 1994. Galatians. Illinois: Inter-Varsity Press.

Hansen, L. (ed). 2005. The legacy of Beyers Naudé: Beyers Naudé Centre Series on Public Theology, 1. Stellenbosch: AFRICAN SUN MeDIA. https://doi.org/10.18820/9781919980997

Hansen, L. and Vosloo, R. (eds). 2006. Oom Bey for the future: engaging the witness of Beyers Naudé: Beyers Naudé Centre Series on Public Theology, 2. Stellenbosch: AFRICAN SUN MeDIA.

Hawking, S. 1989. A Brief History of Time. From the Big Bang to Black Holes. London: Bantam Press.

Hawking, S. and Mlodinow, L. 2010. The Grand Design. New Answers to the Ultimate Questions of Life. London: Bantam Press.

Heimbrock, H.G. 1993. Gottesdienst: Spielraum des Lebens. Sozial - und Kulturwissenschaftliche Analysen zum Ritual in praktisch-theologischem Interesse. Kampen: Deutscher Studien Verlag.

Hiroka, S. 2012. Steve Reich's 'Musical Process': A Linkage with Post-minimal Art. Aesthetics. The Japanese Society for Aesthetics (pdf). Available at: https://bit.ly/2Jdf4qu 16:66-77.

Hopkins, D. 2004. Dada and Surrealism: A Very Short Introduction. Oxford: Oxford University Press. https://doi.org/10.1093/actrade/9780192802545.003.0001

Horsley, I. 1980. Improvisation. The New Grove Dictionary of Music and Musicians, 9, 2nd Edition. London: Oxford University Press.

Howard-Brook, W. and Gwyther, A. 1999. Unveiling Empire: reading Revelation then and now. Maryknoll, NY: Orbis Books. 
Human Sciences Research Council (HSRC) 1994. Preaching in contexts of change. An investigation into preaching on Radio South Africa, Afrikaans Stereo and Radio Pulpit before and after the general elections of 1994. Stellenbosch: HSRC.

Huber, W. 2012. After Fukushima: The precautionary principle revisited. Verbum et Ecclesia, 33(2). https://doi.org/10.4102/ve.v33i2.736

Huizinga, J. 1955. Homo ludens; a study of the play-element in culture. Boston: Beacon Press.

Hunsberger, G. 1995. Cutting the Christendom Knot. In Chiba, S., Hunsberger, G.R., Ruiz, L. E. J. and West, C.C. (eds). Christian Ethics in Ecumenical Context: Theology, Culture, and Politics. Grand Rapids, MI: Wm. B. Eerdmans Publishing Company.

Idowu, E.B. 1991. African Traditional Religion: A Definition. London: Fountain Publications.

Ihlenfeld, K. 1965. Te deum heute. 365 Texte zur Krisis des Christentums. Witten u. Berlin: Eckart.

Imbo, S.O. 1998. An Introduction to African Philosophy. Lanham: Rowman \& Littlefield.

IMDb (Internet Movie Database). Forever Young, Forever Free (1975) (online movie poster). Available at: https://www.imdb.com/title/tt0074542/

Jager, O. 1962. Het Eeuwige Leven met name in verband met de verhouding van tijd en eeuwigheid. Kampen: Kok.

Jonas, H. 1984. The imperative of responsibility: In search for an ethics for the technological age. Chicago: University of Chicago Press.

Josuttis, M. 1966. Gesetzlichkeit in der Predigt der Gegenwart. München: Kaiser Verlag.

Joubert, A. 2004. The power of performance: Linking Past and Present in Hananwa and Lobedu Oral Literature. Berlin: Mouton de Gruyter.

Jüngel, E. 1974. Metaphorische Wahrheit. Erwägungen zur theologischen Relevanz der Metaphor als beitrag zur Hermeneutik einer narrativen Theologie. München: Kaiser Verlag. https://doi.org/10.14315/evth-1974-sh05

Kapogianni, E. 2011. Irony via 'surrealism': The humorous side of irony. In Dynel, M. (ed). The Pragmatics of Humour across Discourse Domains. Amsterdam: John Benjamins Publishing Company. https://doi.org/10.1075/pbns.210.05kap

Katani, A.M. 2008. Traditional Malawian Choral Music: A Liturgical-Critical Study within the Church of Central Africa Presbyterian (CCAP) - Nkhoma Synod (unpublished DTh). Stellenbosch: Stellenbosch Univeristy.

Kempen, M. 2016. Coaching als abduktiver Prozess vor dem bleibenden Geheimnis. Die Theorie U aus pastoralpsychologischer Perspektive. Münster: Lit Verlag. 
Keshgegian, F.A. 2000. Redeeming Memories. A Theology of Healing and Transformation. Nashville: Abingdon Press.

Kierkegaard, S. 1844. The Concept of Anxiety: A Simple Psychologically Orienting Deliberation on the Dogmatic Issue of Hereditary Sin. Princeton, New Jersey: Princeton University Press 1980.

Kierkegaard, S. 2006. Fear and Trembling. Translated by S. Kierkegaard and A. Hannay. London: Penguin Books.

Kierkegaard, S. 1949. Die Tagebücher, 1834-1855. München: Kösel.

Kirk, G.S. 1973. Myth: its meaning and functions in ancient and other cultures. Berkeley: University of California Press.

Klomp, M. and Barnard, M. 2017. Sacro-Soundscapes: Interpreting Contemporary Ritual Performances of Sacred Music through the Case of 'The Passion' in the Netherlands. International Journal of Practical Theology, 21(2):240-258. https://doi.org/10.1515/ijpt-2016-0030

Koopman, N. 2002. Freedom of religion and the prophetic role of the church. In NGTT: Dutch Reformed Theological Journal, 43(1,2):237-247. http://dx.doi.org/10.17570/ngtt.2002.v43n1.a21

Krieg, G.A. 1993. Nachschöpferische Freiheit. Ein musikalischtheologisches Plädoyer für die Orgelimprovisation. In Mundry, J. (ed) Musik und Kirche, 63(4):204-209.

Kritzinger, K. and Saayman, W. (eds). 2011. David J. Bosch. Prophetic integrity, cruciform praxis. Dorpspruit: Cluster Publications. 167-173.

Kümmel, W.G. 1974. Theology of the New Testament. London: SCM.

Landau, R. 1981. Komm, Heiliger Geist, du Tröster wert... Gestaltungen des Heiligen Geistes,41(3):187-211. https://doi.org/10.14315/evth-1981-0302

Landres, J.S. and Stier, O.B. 2006. Introduction. Religion, Violence, Memory, and Place. Bloomington and Indianapolis: Indiana University Press. 1-12.

Lange, E. 1968. Die verbesserliche Welt-Möglichkeiten christlicher Rede erprobt an der Geschichte von Jona. Stuttgart: Kreuz Verlag.

Lange, E. 1976. Zur Aufgabe christlicher Rede. In Schloz, R. (ed). Predigen als Beruf. Stuttgart: Kreuz Verlag.

Lange, E. 1976. Zur Theorie und Praxis der Predigtarbeit. In Schloz, R. (ed). Predigen als Beruf. Stuttgart: Kreuz Verlag.

Langerman, I.H. n.d. Karoo night - Colesberg - South Africa. Pinterest (online photo). Available at: https://za.pinterest.com/pin/517632550901746478

Lapsley, M. 1996. Bearing the Pain in our Bodies. In Botman, H.R. and Petersen, R.M. To Remember and to Heal. Theological and Psychological Reflections on Truth and Reconciliation. Cape Town: Human and Rousseau. 17-23.

Lewis, C.S. 2001. Mere Christianity. New York: Harper Collins.

Lewis, C.S. 2001. The Screwtape Letters. New York: Harper Collins. 
Lindroos, K. 1998. Now-Time Image-Space. Temporalization of Politics in Walter Benjamin's philosophy of History and Art. Jyvaskyla, SoPhi: Jyvaskyla University Print House.

Litnet, 2017. References to Gifkaroo. Smith, S., Viljoen, L., De Wit, H.J. et al. (online). Available at: https://www.litnet.co.za/search/?q=gifkaroo [Accessed 18 May 2017].

Lloyd-Jones, D.M. 1976. Preaching and Preachers. London: Hodder and Stoughton.

Louw, D.J. 2014. Icons. Imaging the Unseen. On beauty and healing of life, body and soul. Stellenbosch: AFRICAN SUN MeDIA.

Louw, D. J. The Perichoresis of an Encircling God. Re-interpreting the Rublev Icon on Trinity: The Infiniscience of the Hospitable God of Abraham, Isaac, and Jacob. HTS Theological Studies (in press 2019).

Lubbe, G. 1993. A Christian perspective on religious freedom in the South African context. In Kilian, J. (ed). Religious Freedom in South Africa. Pretoria: Unisa.

Luther, M. 1883. Weimarer Ausgabe (WA). Weimar: Hermann Böhlau. 40(1):174; 17(II):192.

Luther, M. and Brandt, W.I. (ed). 1962. Luther's Works, 45. Philadelphia, PN: Muhlenberg Press.

Maluleke, T. 2008. Justice in post-apartheid South Africa: Towards a Theology of Restitution. Verbum Et Ecclesia, 3:681-696. https://doi.org/10.4102/ve.v29i3.36

Marina of the Zabbaleen, 2008 (film). Directed by Engi Wassef. USA: Torch Films

Markwei, M. 1979. Life in our Village. In Zebala, P. and Rossel, C. (eds). African Writing. Bournemouth, UK.

Matthews, V. H. 2003. Physical Space, Imagined Space, and 'Lived Space' in Ancient Israel. Biblical Theology Bulletin, 33(1):12-20. https://doi.org/10.1177/014610790303300103

Mbiti, J. 1971. Introduction to African Religion. London: Heinemann.

Mbiti, J. 1990. The Concept of Time. African Religions and Philosophy. London: Heinemann. 15-28.

McFague, S. 1987. Models of God. Theology for an Ecological, Nuclear Age. Philadelphia: Fortress.

McGann, M.E. 2002. Exploring Music as Worship and Theology. Research in Liturgical Practise. Collegeville, Minnesota: The Liturgical Press.

McGrath, A.E. 1985. Luther's theology of the Cross: Martin Luther's theological breakthrough. Oxford: Blackwell.

Meisler, F. 2008. Kindertransport - Trains to Life, Trains to Death (online photos of bronze sculpting). Available at: https://bit.ly/2Xgspbx

Merton, T. 1977. Raids on the unspeakable. New York: New Directions. 
Miller, P.D. Jr 2003. The Prophet's Sons and Daughters, Amos 7:10-17; Acts 3:17-26. In Resner, A. Jr (ed). Just Preaching. Prophetic Voices for Economic Justice. St. Louis, Missouri: Chalice Press.

Miskotte, K.H. 1965. Als de goden zwijgen. Haarlem: Callenbach.

Mitscherlich, A. and Mitscherlich, M. 1967. Die Unfähigkeit zu trauern. Grundlagen kollektiven Verhaltens. München: Piper Verlag.

Moltmann, J. 1969. Geloof in de toekomst. Utrecht: Amboboeken.

Moltmann, J. 1974. The Crucified God. Evanston, IL: Harper and Row. https://doi.org/10.1177/004057367403100102

Moltmann, J. 1975. The Experiment Hope. London: SCM Press. 177-178.

Moltmann, J. 1981. The Trinity and the Kingdom. New York: Harper and Row.

Mugambi, J. 2003. Christian Theology and Social Reconstruction. Nairobi, Kenya: Acton Publishers.

Müller, B.A. 1987. Tendense in Afrikaanse Godsdiens Programme. Stellenbosch: Stellenbosch University.

Müller, C.F.J. (ed). 1980. Vyfhonderd jaar Suid-Afrikaanse geskiedenis. Cape Town: Tafelberg Publishers.

Mundle, W. 1975. Come. In Brown, C. (ed). The New International Dictionary of New Testament Theology, 1. Exeter: The Paternoster Press. 319-324.

Münkler, H. 1997. Politik. Theologische Realenzyklopädie, Bd 27, 1-6. Berlin/New York.

Naudé, B. 1995. My Land van Hoop: Die Lewe van Beyers Naudé. Cape Town: Human \& Rousseau.

Naudé, B. 2005. The Afrikaner and Race Relations. In Hansen, L.D. (ed). The Legacy of Beyers Naudé. Stellenbosch: AFRICAN SUN MeDIA.

Naudé, B. 2013. Vreesloos Gehoorsaam. In Coetzee, M., Hansen, L. and Vosloo, R.(eds). 'n Keur uit Beyers Naudé se preke 1939-1997. Beyers Naudé Centre Series on Public Theology. Stellenbosch: AFRICAN SUN MeDIA.

New English Bible (n.d.).

Newbigin, L. 1989. The Gospel in a Pluralist Society. Grand Rapids, MI: Wm. B. Eerdmans Publishing Company.

Newton-Smith, W.H. 1989. Space, Time and Space-Time: A Philosopher's View. In Flood, R. and Lockwood, M. (eds). The Nature of Time. Oxford: Basil Blackwell.

Nicholls, T. 2012. An Ethics of Improvisation: Aesthetic possibilities for a Political Future. Lanham MD: Lexington Books.

Nickas, R. 2016. Felix Gonzalez-Torres. Flash Art (online). Available at: https://flash---art.com/article/felix-gonzalez-torres/\#

Nicol, M. and Deeg, A. 2012. Einander ins Bild setzen. In Charbonnier, L., Merzyn, K, and Meyer, P. (eds). Homiletik. Aktuelle Konzepte und ihre Umsetzung. Göttingen: Vandenhoeck \& Ruprecht. 68-84. 
Nieder-Heitmann, J.H. 1981. An Analysis and Evaluation of John S. Mbiti's Theological Evaluation of African Traditional Religions (unpublished MTh). Stellenbosch: Stellenbosch University.

Niehaus, A. 1992. The Central Sanctuary: Where and When? Tyndale Bulletin, 43(1). 3-30.

Nietzsche, F. 1973. Die fröhliche Wissenschaft (1882). Nietzsche (KGA), 5(2).

Nixon, R. 2011. Slow Violence and Environmental Storytelling. Niemanstoryboard (e-journal). Available at: https://bit.ly/2NiTBC2 [Accessed 12 April 2017].

Nolan, A. 1985. The option for the poor in South Africa. In Villa-Vicencio, C. and De Gruchy, J.W. (eds). Resistance and Hope. South African essays in honour of Beyers Naudé. Grand Rapids, MI: Wm. B. Eerdmans Publishing Company.

Nolland, J. 1998. Word Biblical Commentary, Luke 9:21-18:34. Dallas, Texas: Word Books. 35(b).

Noordmans, O. 1939. Liturgie. Amsterdam: Uitgeversmaatschappij Holland.

Otto, R. 1917. Das Heilige. Über das Irrationale in der Idee des Göttlichen und sein Verhältnis zum Rationalen. München: Biederstein.

Ottoni-Wilhelm, D. 2003. God's Word in the World: Prophetic Preaching and the Gospel of Jesus Christ In Greiser, D.B. and King, M.A. (eds). Anabaptist Preaching: A Conversation Between Pulpit, Pew and Bible. Telford, PA: Cascading Publishing House. 84-91.

Our Lady's Warriors, 1998. St. Augustine's Confessions. Available at: http://www.ourladyswarriors.org/saints/augcon11.htm\#chap20

Patterson, S.J. 1989. Fire and Dissension: Ipsissima Vox Jesus in Q 12:49, 51-53? Forum, 5(2):121-139.

Perry, A. 2010. The Laughing Bishop. Time Magazine, Monday 11 October 2010.Peters, V. 2012. Kwalitan - importeren en segmenteren (video online). Available at: https://www.youtube.com/user/Kwalitan

Pew Research Centre, 2017. Pew-Templeton Global Religious Futures Project: The Future of World Religions, (online). Available at: http://globalreligiousfutures.org/

Pieterse, H.J.C. (ed). 2001. Desmond Tutu's Message: A Qualitative Analysis. Köln: Brill.

Pieterse, H.J.C. 2005. Hoe kom God aan die woord in die prediking? 'n Vaste vertroue op God is teologies noodsaaklik. Practical Theology in South Africa, 20(2):120-129.

Pieterse, H.J.C. 2010. Die Keuse van 'n model vir inhoudsanalise van preke oor armoede en aan armes as hoorders. Die Skriflig, 44(2):1-16. https://doi.org/10.4102/ids.v44i1.140

Pieterse, H.J.C. 2011. An Open Coding Analytical Model of Sermons on Poverty with Matthew 25:31-46 as Sermon Text. Acta Theologica, 31(1):95-112. https://doi.org/10.4314/actat.v31i1.6 
Pleizier, T. 2010. Religious involvement in hearing sermons. A Grounded Theory study in empirical theology and homiletics. Delft: Eburon Academic Publishers.

Plum, R. 2005. Spreken over God: een theologische vergelijking tussen het symboolbegrip van Paul Ricoeur en Ernst Bloch. Kampen: Kok.

Plüss, D. 2012. Texte inszenieren. In Charbonnier, L., Merzyn, K, and Meyer, P. (eds). Homiletik. Aktuelle Konzepte und ihre Umsetzung. Göttingen: Vandenhoeck \& Ruprecht. 19-136.

Pohlmann, L. and Niedersen, U. 1991. Jenseits der linearen Zeit. Jahrbuch für Komplexität in den Natur- Sozial- und Geisteswissenschaften. Band II: Der Mensch in Ordnung und Chaos. Berlin: Duncker and Humblot. 169-184.

Popp, F. 2004. Über die unterschiedliche Wahrnehmung der Zeit. Multikulturelles Zeitschrift. Nürnberg, 7(1)7.

Postma, E. 2008. Dilettant, pilgrim, nar: De positie van C. W. Mönnich in cultuur en theologie. Jaarboek voor liturgie-onderzoek, 24. Utrecht: Eburon Uitgever-j. 247-259.

Powell, M. 2016. Southern African Rock Art. Slide Player (online). Available at: https://bit.ly/2Lol9Du

Priestly, J.B. 1964. Man and Time. London: Aldus Books Limited.

Pro Veritate, 15 January 1972. In Llewellyn, D. and Sawyer, D.F. (eds). Reading Spiritualities. Constructing and Representing the Sacred. Burlington: Ashgate. 5.

Purcell, M. 2001. 'This Is My Body' Which Is 'For You' ... Ethically Speaking. In Boeve, L. and Ries, J.C. (eds). The Presence of Transcendence. Thinking 'Sacrament' in a Postmodern Age. Paris: Peeters. 135-152.

Queen 1989. The Miracle: I want it all. Capitol Records US (Spotify web player). Available at: https://open.spotify.com/album/7kiDOzNkoKCEgqGZrpPrej

Reich, S. 2002. Music as a Gradual Process. In Hilliers, E.P. (ed). Writings on Music 1965-2000. New York: Oxford University Press. 34-51. https://doi.org/10.1093/acprof:oso/9780195151152.003.0004

Reschke, R. 2010. Schön/Schönheit. Ästhetische Grundbefriffe, 5. Stuttgart, Weimar: J.B. Metzler. https://doi.org/10.1007/978-3-476-00547-2_13

Richter-Böhne, A. 1989. Unbekannte Schuld. Politischer Predigt unter alliierter Besatzung. Stuttgart: Calwer Verlag.

Ricoeur, P. 1988. Time and Narrative, 3. Translated by K. Blamey and D. Pellauer. Chicago and London: University of Chicago Press. https://doi.org/10.7208/chicago/9780226713533.001.0001

Ricoeur, P. 2004. Memory, history, forgetting. Chicago: University of Chicago Press.Riese, U. 2010. Entdifferenzierung des Ästhetischen - und keine Enthierarchisierung? In Barck, K., Fontius, M., Schlenstedt, D., Steinwachs, B. and Wolfzettel, F. (eds). Ästhetische Grundbegriffe, 5.

Stuttgart: J.B. Metzler. 29-39. 
Rilke, R.M. 1978. Duineser Elegien. In Nalewski, H. (ed). Rilke, Werke in drei Bänden, 1. Leipzig: D. Kliche.

Rosenkranz, K. 1996. Ästhetik des Hässlichen (1853). Leipzig: D. Kliche.

Roux, T. 2008. Land restitution and reconciliation in South Africa. In Du Bois, F. and Du Bois-Pedain, A. (eds). Justice and Reconciliation in Post-Apartheid South Africa. Cambridge: University Press.

RSA (Republic of South Africa). 2008. National Environmental Management Waste Act 59 of 2008. Pretoria: Government Printing Works. 525.

RSA DoEA (Republic of South Africa. Department of Environmental Affairs). 2012. National Waste Information Baseline Report. Government Gazette (pdf). Available at: https://bit.ly/2FPYkUv

RSA DoMR (Republic of South Africa. Department of Mineral Resources). 2012. Report on investigation of hydraulic fracking in the Karoo basin in South Africa. Government Gazette (pdf). Available at: https://bit.ly/2X8lxYW

Saayman, W. 2010. Missionary or missional? A study in terminology. Missionalia, 38(1):5-16.

Schelsky, H. 1979. Die Hoffnung Blochs: Kritik der marxistischen Existenzphilosophie eines Jugendbewegten. Stuttgart: Klett-Cotta.

Schmalz, T. 2012. Homeless Jesus. Sculptor by Timothy P. Schmalz (online). Available at: https://bit.ly/2LGHVq7

Schmit, C.J. 2008. What comes next? Performing Music and Proclaiming the Word. In Childers, J. and Schmit, C.J. (eds). Performance in preaching (engaging worship): Bringing the sermon to life. Grand Rapids, MI: Baker Academic. 169-190.

Schoeman, C. 2013. The Historical Karoo. Traces of the Past in South Africa's Arid Interior. Cape Town: Zebra Press.

Schreiner, O. 2013. Thoughts on South Africa. London: Forgotten Books.

Schuman, N. 2001. Gedenken. In Barnard, M. and Post, P. (eds). Ritueel Bestek. Antropologische kernwoorden van de liturgie. Meinema: Zoetermeer. 181-186.

Sellew, P. 1987. Reconstruction of Q 12:33-59. In Richards, K.H. (ed). SBL Seminar Papers 1987. Atlanta, GA: Scholars Press. 617-668.

Shale Stuff. 2014. Diagram of a Typical Hydraulic Fracturing Operation. The Process of Fracking (online). Available at: https://bit.ly/2E6mESY

Shell South Africa. Projects and sites: The Karoo (online). Available at: https://www.shell.co.za/about-us/projects-and-sites/the-karoo.html/accessed [Accessed 22 May 2017].

Smit, D. 1984. Wat beteken status confessionis? In Cloete, D. and Smit, D. (eds). 'n Oomblik van waarheid. Opstelle rondom die NG Sendingkerk se afkondiging van ' $n$ status confessionis en die opstel van ' $n$ konsepbelydenis. Cape Town: Tafelberg Publishers. 14-38.

Smit, D. 1987. Hoe verstaan ons wat ons lees? 'n Dink - en werkboek oor die hermeneutiek vir predikers en student. Cape Town: NG Church Publishers. 
Smit, D. 2014. Resisting 'Lordless powers'? - Boesak on power. In Dibeela, P., Lenka-Bula, P. and Vellem, V. (eds). Prophet from the South: Essays in honour of Allan Aubrey Boesak. Stellenbosch: AFRICAN SUN MeDIA.

Sommer, B. 2001. Conflicting constructions of divine presence in priestly tabernacle. Biblical Interpretation, 9:48,49. https://doi.org/10.1163/156851501300112353

Stein, G. 1922. Geography and Plays. Mineola, NY: Dover Publications.

Steinmetz, U. and Deeg, A. (eds). 2018. Blue Church. Improvisation als Klangfarbe des Evangelischen Gottesdienstes. Beiträge zu Liturgie und Spiritualität, 3. Leipzig: Evangelische Verlagsanstalt.

Swart, I. 2004. Community-centred congregational ministry in South Africa: a plea for renewal. NGTT: Dutch Reformed Theological Journal, Supplementum, 45(2):328-339. http://dx.doi.org/10.17570/ngtt.2004.v45s1.a15

Swart, I. 2008. Meeting the Challenge of Poverty and Exclusion: The Emerging Field of Developmental Research in South African Practical Theology. International Journal of Practical Theology, 12(1):104-149. https://doi.org/10.1515/IJPT.2008.6

Swinton, J. 2016. Becoming Friends of Time: Disability, Timefullness, and Gentle Discipleship. Waco, Texas: Baylor University Press.

Tacheles: How long is now, 2010. Abandoned Berlin (online). Available at: https://bit.ly/2Sb9Sb7

Tandberg, S.E. 2008. Imagination, Form, Movement and Sound. Studies in Musical Improvisation. Gothenburg: ArtMonitor.

Terrien, S. 1978. The Elusive Presence. Toward a New Biblical Theology. San Francisco: Harper and Row.

Theisen, B. 2010. Chaos-Ordnung. Ästhetische Grundbegriffe, 1. Stuttgart: Weimar: J.B. Metzler. https://doi.org/10.1007/978-3-476-00520-5_23

Tillich, P. 1962. Aufder Grenze. Aus dem Lebenswerk Paul Tillichs. Stuttgart: Evangelisches Verlagswerk.

Tisdale, L.T. 2010. Prophetic Preaching: A Pastoral Approach. Louisville: Westminster John Knox.

Troeger, T. 1999. The Landscapes of the Heart. How our Imagined Worlds Shape the Preaching of the Gospel. In Kato, T. (ed). Preaching as God's Mission. Studia Homiletica, 2. Tokyo: Kyo Bun Kwam.

Tutu, D. 1983. Hope and Suffering: Sermons and Speeches. Johannesburg: Skotaville Publishers.

Tutu, D. and Van Roekel, D. 2010. Facing the Future: Global Education at the Crossroads. Huffington Post (online). Available at: https://bit.ly/2FBqPWM [Accessed 9 August 2015].

Tutu, D. 2011. God is not a Christian. Speaking Truth in times of Crisis. London: Rider. 
Tutu, D. n.d. Desmond Tutu quotes. Think Exist (online). Available at: https://bit.ly/2xeBWR2 [Accessed 9 August 2015].

Tweed, T.A. 2006. Crossing and Dwelling. A Theory of Religion. Cambridge, Mass: Harvard University Press. https://doi.org/10.4159/9780674044517

Vaessen, J.C. 1997. Tussen Schrift en preek. Ontwerp van een analysemodel voor de bijbelinterpretatie in preken met gebruikmaking van de tekstuele hermeneutiek van Paul Ricoeur. Kampen: Kok.

Van Heerden, E. 2013. Poison Karoo. Translated by I. Dixon. Cape Town: Tafelberg Publishers.

Van Ruler, A.A. 1974. De Vervulling van de Wet. Een Dogmatische Studie over de Verhouding van Openbaring en Existentie. Nijkerk: G.F. Callenbach.

Van Tonder, G. and Tucker, R. 2014. Karoo fracking and the Christian faith community. HTS Theological Studies, 702:1-8. https://doi.org/10.4159/9780674044517

Van Troostwijk, C.D. 2005. Theopathie. Afrikaanse Kunst als moeder van de theologie. Wêreld en Zending. Tijdschrift voor interculturele theologie, 1:18-26.

Van Wengen-Shute, R. 2003. Time and Liturgy in George Herbert's The Temple. Theology: Sage Journals March/April, 106(830) 98-107. https://doi.org/10.1177/0040571X0310600204

Villa-Vicencio, C. 1998. A Theology of Reconstruction. Nation-Building and Human Rights. Cape Town: David Philip Publishers.

Vögtle, A. 1976. Todesankündigung und Todesverständnis Jesu. In Kertelge, K.(ed). Der Tod Jesu: Deutungen im Neuen Testament Freiburg: Herder. 51-113.

Von Baeyer, H. 1984. Gravity. Rainbows, Snowflakes, and Quarks: Physics and the World around Us. New York: McGraw-Hill, 1984.

Vosloo, R. 2007. Reconfiguring ecclesial identity: In conversation with Paul Ricoeur. Studia Historiae Ecclesiasticae. Journal of the Church History Society of Southern Africa, 32(1):273-293. https://doi.org/10.1515/9783110569810-020

Vosloo, R. 2018. Time, memory and the search for a responsible engagement with the past. In Charbonnier, L., Cilliers, J., Mader, M., Wepener, C. and Weyel, B. (eds). Pluralisation and Social Change. Dynamics of lived religion in South Africa and in Germany. Berlin: De Gruyter.

Wainwright, G. 1983. The Ecumenical Moment. Crisis and Opportunity for the Church. Grand Rapids, MI: Wm. B. Eerdmans Publishing Company.

Wainwright, G. 1996. For Our Salvation. Two Approaches to the work of Christ. Grand Rapids, MI: Wm. B. Eerdmans Publishing Company.

Wallace, M.I. 2001. The Green Face of God: Recovering the Spirit in an Ecocidal Era. In Hinze, B.E. and Dabney, D.L. (eds). Advents of the Spirit: An Introduction to the current Study of Pneumatology (online). 444-464. Available at: https://works.swarthmore.edu/fac-religion/81 
Wells, S. 2004. Improvisation. The Drama of Christian Ethics. Ada, MI: Baker Academic \& Brazos Press.

Wilson, P.S. 2008. Preaching, Performance, and the Life and Death of 'Now'. In Childers, J. and Schmit, C.J. (eds). Performance in preaching (engaging worship): Bringing the sermon to life. Grand Rapids, MI: Baker Academic.

Wiredu, K. 1991. On Defining African Philosophy. In Serequeberhan, T. (ed). African Philosophy: The Essential Readings. New York: Paragon House.

Wit, M.J. 2010. The great shale debate in the Karoo. South African Journal of Science. 107. 02-10. 10.4102/sajs.v107i7/8.791.

Wittgenstein, L. 1967. Philosophische Untersuchungen, 329(77). Frankfurt: Suhrkamp.

Woodhouse, B. 2003. Bushman Art of Southern Africa. 40 Significant Bushman Rock-art Sites. Cape Town: Art Publishers.

World Wide Fund, n.d. How many species are we losing? (online). Available at: http://wwf.panda.org/our_work/biodiversity/biodiversity/ [Accessed 5 November 2018].

Zapiro 2011. Royal Dutch Shell fracking in the Karoo. The Times (online). Available at: https://bit.ly/2JbULtE 